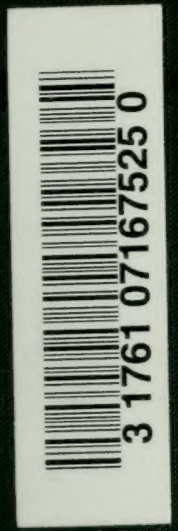


lu 
Digitized by the Internet Archive in 2009 with funding from University of Toronto 



\title{
HALF A CENTURY
}

oF

\section{AUSTRALASIAN PROGRESS,}

A PERSONAL RETROSPECT.

\author{
PART I. \\ ItINERARy OF THE TOUR OF a Revisit.
}

PART II.

A Series of Articles on General Questions of Australasta,

The Colonies, and The Empire Generally.

BY

\section{WILLIAM WESTGARTH}

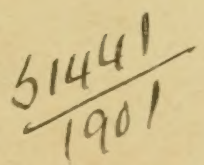

LONDON:

SAMPSON LOW, MARSTON, SEARLE, \& RIVINGTON, LIMITED,

St. Dुnnstan's हैouse,

Fetter Lane, Fleet Street, E.C.

1889.

[All rights reserved.] 
LONDON :

PRINTED BY WILLLAM CLOWES AND SONS, LIMITED, STAMFOLD STREET AND CHARING CROSS. 


\section{PREFATORY REMARKS.}

"We regard the Colonies as integral parts of the Empire, and our warmest sympathies are with our brethren beyond the seas, who are no less dear to us than if they dwelt in Surrey or Kent."- Speech of the Prince of Wales at the "coming of age" dinner of the Royal Colonial Institute, 13th March, 1889.

\section{Some more Recent Occurrences.}

Mr Preface is not a little in the nature of a Postscript. Events have a quick succession in Australasian colonial life. Ere an ordinary volume like this can be passed through the press, much that is fresh or additional upon its subject may have occurred which an author would still like to notice. Amongst other events in so brief a space have been these three of no small significance. First, the late elections in New South Wales, as was not altogether unexpected, have at last threatened the free-trading position which the Colony, mainly under Sir Henry Parkes's vigorous hands, has hitherto been able to maintain. Colonists, whenever they quit their mother's leading, seem unable to save themselves from the common lapse into "protection," although every distinguished economist, without one single exception, has declared and demonstrated, that for any society to restrict its own market, and to limit 
its own sphere of exchange, must be self-evident folly and loss. Second, yet one further conference upon Intercolonial Federation has separated once more without result. Upon these events, the latter even more untoward than the first, I must say a few words in this preface further on. Third, just as I go to press, we have had the important speech of the Prince of Wales, a sentence from which, as quoted above, cannot fail to promote the great cause in whose interest it was spoken.

A fourth subject is also recently to the front, in more assured hope of success than before, namely, the admission of our colonial stocks into the highly privileged list for Trust investment. There seems no doubt now that this privilege will be conceded very shortly. Our distinguished Chancellor, even as a mere matter of business, could not allow this concession to interfere, as undoubtedly it would have done, with his great, Consols' Conversion scheme. But that completed, the way for the other will be clear. Australasia must not miss this happiest of opportunities for inaugurating her coming-her inevitable-Three per cents. Each Colony might issue, as the privileged stock, an uniform Three per cent. Into this all the previous outstandings, respectively, might be gradually converted. Thus the foundation might be laid of a great Australasian Dominion stock, a worthy substitute in point of security, as we may hope, for the old parental Threes which have just expired. 


\section{Some Prominent Public Questions dealt with.}

In the course of my Australasian tour my attention was called to a variety of high public questions of the day, most of them of very great current interest and importance, alike to the Colonies and the Empire. In giving my views upon these questions, I not only speak as from the very ground and scene of the questions, but also out of a length and variety of colonial experience which not many could claim to exceed. I have discussed them with all due freedom, feeling that my views are mostly those of thorough conviction. If I have aimed at a touch of humour to suitably lighten some subjects having perhaps a leaden character to many readers, I shall not be misunderstood-not even if the humour be but moderately visible.

These questions then, wherever or whenever they crossed my path, I have endeavoured duly to discuss. They already arise in considerable number and diversity. They are Australasian questions, questions of the Colonies in general, and questions of the whole Empire. One of them, for example, is the improvement, by means of irrigation and otherwise, of the Australian climate, a subject which is now commanding very general attention on the spot, and in which is involved a progress that, as even now exceeding all the marvels of the past, may be regarded as prospectively in the region of the incalculable. 
Another question pertains to still improved intercommunications, especially as to the high desideratum of speed, in which, as must yet be confessed, our Australasian "Lines" are so completely outstripped by those between Liverpool and America. I might have included another question, not unconnected with this of the speed of intercommunication, namely the great Postal question, colonial and general, if it had not been of late wielded with such exemplary vigour and pertinacity by my friend, Mr. Henniker Heaton, M.P. for Canterbury. Then follow certain graver questions, such as, first, the policy of the extension of the Empire, a subject on which there are now indications of a changed feeling at Home, and one more in accordance with the colonial view, which has usually regarded the utmost possible extension amongst the unclaimed areas of savage peoples as the most likely to result in excluding future foreign complications, and giving to the Empire the minimum of possible future danger or disturbance. Second comes the equally grave question of the socio-political principles of the Empire's government, a question which concerns mainly the well-being of the non-British races of our tropical colonies.

Selection of the most important of these Questions.

Making a comparative estimate of the degree of importance of these various questions, the four following strike me as not only the most important, 
but as those which press most immediately for settlement. First, the Chinese question, which is really one of our being some day l, lotterl out or flooded out of national existence in certain of our ('olonies by a possible countless swarm of non-associable human beings, with whom our only chance is by a timely exclusion. Second, the confederation of natural colonial groups, as the Canadian, Cape, and Australasian respectively, into one general govermment. Third, the grandest as well as gravest of all these questions is that of the political unity of the Emprire, so as to bind effectively together this greatest of national structures which the world has ever seen in all the power and influence, and the gruidance of wisdom and experience, which is possible to all its circumstances.

There is still a fourth question, that of the final result of an united empire as to trading freedom or trading self-restriction to our vast and varied interests. Such experience as we have is, I fear, opposed to any hope that the colonial groups, when they respectively federate, will do otherwise than follow the Canadian example into protection. But when the lively and most interesting battle opens over the whole Empire, as it will do at once upon the completion of the political unity now so universally desired, I do not doubt that the mother's influence will prevail, even where common sense has failed, to hinder her children from damaging by their restrictions their own prosperity and prospects. 


\section{The United Empire the Greatest Question.}

The United Empire is undoubtedly the greatest, as well indeed as the most urgent, of all our present questions; and, as it is one on which I have bestorved much serious attention, I feel disposed to deal with it in a practical way leading to action. It is chiefly for the opportunity of some further remarks on this question, suggested by what has come further under my observation upon it since this volume was written, that I have taken the liberty of inflicting upon my readers this rather lengthened Preface.

\section{A Colonial View upon it.}

One of the most suggestive views I have as yet met with on the question of the Unity of the Empire is given in an article of the (Melbourne) Australasian weekly paper of 13th October last, which every one interested, and proposing to give in any way a help to the cause, should read. But, as many may not have the opportunity, I shall here recall its substance. As I left Melbourne two days before the mublication, I did not happen to read it until all my volume was in type, so that I must needs bring it up here.

The writer of the article does not in the least doul,t the general desire of the colonists to be united, or to remain united, with the great Empire of their fe!low-countrymen, and that is evidently aloo lis own personal feeling. But difficulty and 
disagreement begin at once whon we come to the steps that are to be taken to effect this object. The writer continues, on this further point also, to speak not only for his fellow colonists, but seemingly also from his own feeling. He says, in effect, "We dislike the idea of an Imperial Executive orershadowing us; we dread a Parliamentary rule that is to be above our own; we are nervous, whether really or affectedly, even about a federated English Cabinet, because we fear it might wield too much power," and so on, and so on.

Now, the utter contradiction implied here may not be fully apparent to those who, like our Australian colonists, have revelled for nearly the last thirty-five years in that utterly anomalous paradise of being practically their own masters, and yet, while on their part responsible for nothing, full members of an Empire, every part of which their Mother is bound to cherish and defend. Besides the question of the equities of such a case, we see well exemplified the apostolic argument about the body and its members. In the colonial case each member thinks to live for itself, because that is so safe and pleasant under the powerful shelter of the whole body, and yet each is grudging and jealous of the strength which it is to contribute thereto.

In my view all this unreason, so to call it, is simply the natural outcome of the present politically anomalous and self-segregative position of our Colonies. The effect already, during the thirty odd 
years this condition has lasted, is to raise up a serious difficulty; and, if there is a further like term of such anomalous life, the difficulty might possibly be enhanced beyond surmounting. The Empire will simply bleed to death, even if accompanied by the sweet music of the most loyal imperial pliraseology.

\section{The high Importance of Time.}

In this case, then, of course there is no consideration more important than time. I cannot pretend to guess at what exactly passes in the mind of my old friend, Sir IIenry Parkes, on that point. But more times than once in the union morement the delay or abstention of his, the senior and most important Colony, has discouraged or postponed great questions of political or financial import. Thile in the very act of draughting this Preface, the southern telegrams bring us that abortive result of the Intercolonial Federation Conference to which I have alluded, and which will probably cause jears of further delay. "The session of the Australasian Federal Council for 18s9," says the message, "which closed on Monday last, was unimportant and uneventful, judging from the meagre summaries of each day's business. The persistent abstention of the parent Colony, New South Wales, from any recognition of this union of the other Colonies practically paralyses the operation of the Council, and deprives its decisions of that weight and authority they would otherwise possess." 
Is Sir Henry himself so loyal that he can see min danger in delay? In a late speech, also telecraphert quite lately, he had said, speaking of the Intercolonial Union, that ere that came there wonld lie ten Colonies to deal with the question, instead of the present six. He alluded to tropical Australia, with its three prospective Colonies, and perhaps our section of New Guinea as the fumth. But to wait for this would certainly inrolve at least ten to twenty more years of time.

The separate life to which each Colony is now so long accustomed is, no dumbt, one cause of the block that has erer, from one Colony or another, hindered and protracted the union morement. In addition, I doubt not, the tariff question rufles Sir Henry and his Free Trade Gorernment, who are surrouncled, within as well as without their boundaries, by the ccascless hostility of Protection. Indeed the fight already looks ominous for trading freedom even upon his own ground, as the late New South Wales elections have returned Sir Henry"s party in a parliamentary majority of only four rotes.

\section{A Striking Contingency.}

A rather striking contingency comes into view here. If New South Wales were at last to abandon the trading freedom she has so long preserved, and to cripple her exchange resources by the restrictions of protection, she would inevitally, I think, lose the commercial supremacy which she lias of late years 
wrested from her rival junior, Victoria, since the latter lapsed into this restrictive course. Perhaps patriotic Tictorians may see here an additional reason for getting New South Wales committed to Protection like themselves. But I feel bound to admit that, if New South Wales thus sacrificed herself, she would, no doubt, Fery greatly remove the block to Intercolonial Federation, and I may here repeat my view, that everything else, tariffs not excepted, ought to be counted second to the great aim of unity, whether Intercolonial or Imperial.

\section{An Empire Executive.}

The difficulty in question suggests that the bringing together of the Empire should not be encumbered by any great steps into new courses, and for the simple reason that such steps will never be taken. Such are propositions about Federal bodies to supersede or dominate the present Parliaments, Home and colonial; or to fill up the present so-called Imperial Parliament by a huge influx of proportionate colonial elements? I have pointed to the Cabinet as the comparatively easy and effective means of accomplishing Imperial unity. Let us introduce, in a constitutional way, the colonial element there, and at once there is an Empire Executive.

\section{An Intermediate Step.}

Tut even this is a step which Colonies, already (plervilous about steps, may find a difficulty in 
taking. It requires some form of election which the people of each Colony or each federated group will feel to be binding, so as to gire the Empire all its possible influence and strength. On this account I have suggested a still simpler and intermediate step, which is, I think, quite possible to the convenient elasticities of our constitutional method, and may, almost at once, open the road to the final unity of the Empire. What should prevent the Queen, by advice of Her Government, nominating the colonial representative proportion by way of a council of advice, to sit always with the Cabinet?

Although no constitutional powers could be conferred upon the colonial element thus introduced, yet the practical working would gradually make towards an Empire cabinet, while the step would be so significant, that it could hardly fail to be followed by the full constitutional arrangement. I will venture to follow this general proposal by giving the exact detail. There are many colonists of position and experience, residing more or less permanently in this country, from whom such a selection as I suggest could be made. If the Colonial Office feels short of range, the Royal Colonial Institute and the large Colonial Trade Sections of the London Chamber of Commerce will complete its resources. I will suppose that ten members, added for the Colonies to a Home cabinet of sixteen, may be the proportion; say, three each for the Dominion and Anstralasia, two for the 
Cille. and we each for the East and West Indian suttlements of the properly colonial kind. For the present, then, let this proportion of the Cabinet be introuluced by ray of a nominated and advisory hody. The mode of procedure, as it appear's to me, would be fur the Home Gorernment to select these ton names, of course advisedly, and refer them for approvil to the respective Colonies. If these names were sent to the respective governors, these latter would, in a prompt and common-sense way, easily ascertain sufficiently colonial opinion. My expectation is that a loyal and cortial acquiescence would be crerywhere given, while a general interest would Te aroused towards the further derelopment of so significant a first step.

\section{The Parent to the Front at last.}

No small adrantage of this step would be its indicution to the Colonies that their parent was at last giving up that passive attitude of self-effacement in her family which she has so long, and I might even say so incongruously, assumed. To this attitude, additional as it is to the grave political incongruities of the colonial position, I largely attribute the cross graius that on occasions show themselves in Colonies, and which are not altngether (onfinerl to recent exhilitions in Qneensland, although exhibited there more pronouncedly perhaps thin elsewhere. As parent of the family, the Home Government should come more to the front, and 
invite or lead, ather than foilus or stand passire. Of course the former must te done judicionsly, and all the more so, from the Colonies having been so long used to, and perlarps somewhat spoileal by, the latter. The only instance, I think, in which this proper self-issertion lats been mate, namely in the proposition of the colouial Conference of two years past, was met, on the colonial part, with a cordiality of response which must surely have been to the parent all that was expected or desired. And out of that Conference has come, or, more strictly, has been completed, the present most important arrangement for joint naval defence.

Judicious steps, even still more directly teuding towards the unity of the Empire, miglit neet quite as prompt and farouralile a response. I think that in such matters the Home Gorerument has been altogether too timil, as though practically underestimating the great influence it still wields in the Colonies and the solid substratum of loyalty still there. I believe that the easy course which I lave suggested above for taking a preliminary step towards the Empire's political unity would be well taken by the Colonies, and that it would lead inevitably to the completion of that object.

\section{The Culonial Element in the Imperiud Enecutice.}

I have already said on this occasion, ats well as on previous occasions not a few, that the introduction of the colonial element into the Ifone Cabiret might 
result in the happiest effect upon Home party politics. A different view has been expressed on this contingency, to the effect that such unwonted fusion might rather confuse the Home political lines, by introducing, so to say, an alien element, unsrmpathetic with either party. Where, for instance, it is said, would the colonial element stand when there came a change of Gorernment? If so slightly sympathetic with Home party as not to require to "go out" with the one or "come in" with the other, would it not "betray party secrets," or otherwise jumble our systematic party action? Well, but this is to parade the very defects which we hope the colonial fusion will help to reduce or get rid of. On the contrary, there is a good hope that the system of unpatriotic "secrets," and other indications of unseemly party extremes, may be beneficially modified under the new course; so that we may not only apprehend no harm from it, but rather confidently leave the two elements of the future Cabinet, the Home and the colonial, to adjust themselves for the Empire's good as circumstances may suggest. They are to be guided, as M. Thiers said of the Pope, hy "the Providence of events."

If Lord Salisbury might possibly dread, from some past experience, that the colonial partnership meant an nccasional perplexing spoke in the wheel of his Foreign Policy, I would recommend the effective (nire of terminating the present abnormal colonial 
relations, which, out of entire non-responsibility, must ever be fertile in a crop of free talk.

Lastly, in the way of the Empire's unity, is erer apt to be thrust upon the Colonies the bugluear of the Mother country's possible foreign wars, in which the Colonies might have no interest whatever. But, in the first place, the parent's past wars had been mostly made, more or less directly, on account of Colonies. And, again, the Colonies are just as much liable now to hostile attack arising out of such wars as if under the completest political union. Our empire must face its risks in that way like other powers of the world, and the Colonies, since the question came directly before them, have surely shown no shirking disposition.

On the other hand, howerer, the contingency of unity presents some important and not unfavourable considerations. 1. An Imperial policy, in which the colonial element duly weighs, will probably steer even still more clear, if possible, of foreign complications than has been the later steady aim of our Home Government. 2. When the power of the whole Empire is grasped by an adequate and constitutional Executive, every section of it, even the least, is assured that in case of need the whole Empire stands lehind it. 3. When the rest of thie world realises this new position of the Empire, the prospect of any attack from other powers will be materially diminished. 


\section{POS'TSCRIP'T.}

The Late Canadian Invitation to Australia and

\section{Intercolonial Federation.}

One of the latest as well as pleasantest anticipations of an United Empire, as well as the lesser question of an Australasian inter-colonial Federation, has been the invitation from the Dominion to her sister Australia for a meeting on behalf of their mutual commerce. Such approaches from one section of the Empire to another are so proper in themselves, and of so enlivening a character - they are invariably so cordially received, as far at least as a very limited experience yet goes-that the surprise is that they should not be oftener suggested. The Empire girdles the earth in the common bond of English race, and in the common spectacle of a vigorons progress. The various parts have a natural gravitation towards each other. It is surely worth while to have now and again a special conference to consider how still further to extend these natural relitions, and to diminish obstacles and distance.

In Anstralial is cordial response, her proposed alternative that the Camadians should be the visitors, was, I think, a lapply idea. There would be the reduced difliculty of a numerically smaller delegation from the. whe Dominion Gorermment. But far heyond 
that minor matter is the consideration that, while Canada is alrearly familiar to Australia from the facility of access from London, the latter is as yet almost an unknown land to Canatians. Indeed, the narvels, on the one hand, of an unprecedented lace of progress in the Sonthern group, and on the other of the scientific romance of its fauma and flora, which now interest increasing multitudes in this age of extended science cultivation, give the decided preponderance of attraction in that direction. A citizen of Montreal, Quebec, or Toronto, would probalily le far more struck with the appearance of Sydney or Melbourne, than with that of our Hone cities, not excepting even London itself. Of course the larger part of the ilea concurns the future, lut what would impress the Canadian on that point in Australia was the comparative imminence of that future by the unexampled pace of the present. So very much the younger as Australia is, her two capitals, sydney and Mellourne, are each already twice the size of Montreal, the largest city of the Dominion.

\section{Promotion of Intercolonial Federation.}

But I am here rather concerned with the effect of such a risit in stimulating the Australasian Federal movement, when the many representatives of the comparatively small Australian Colonies meet the few, who though few, yet represent a sul-Imperial Power, already not unworthy to compare with not a 
few of the independent powers of the civilized world. Doubtless Australasian federation, when it does come, will take example, more or less, from that so successfully carried out by Canada. If so, then the separate political life of the Australian Colonies, which time has so far endeared to their respective populations, does not cease upon federation. These Colonies merely surrender the federal questions, reserving still their own local administration, and reserving also, as I have proposed, the free hand to each over its tariff, which I believe will be an important facility, or indeed a necessity of the change.

\section{Difference between the Two Groups.}

But I apprehend a great difficulty to Australasia in creating such a numerically ample Federal Parliament as assembles yearly at Ottawa. We must remember, first of all, that ever-busy Australia knows no comparatively leisure season such as that which ice-bound Canada enjoys every winter. And, again, over the immense Australasian area the heavy membership drafts of such a parliament upon the busy colonists, and the great distances, would be serinusly felt. New Zealand, for instance, Fiji, New Guinea, the entire of Tropical Australia, and one or more Colonies of the present West Anstralia, would feel the practical inaccessibility of an Australian ()ttawa, situated probably either at Albury, or lower down the queen of $\Lambda$ ustralian rivers, the Murray. 
These considerations suggest a Federal Body rather in that numerical paucity to be associated with an Executive. Each Colony would elect its small contribution to the dominating body. By making of each Colony one electoral district, the best men would he secured, and the highest representative consideration be given them. This mole seems to me better for a non-party fecleral body than the alternative of a selection by the respective sub-parliaments. 'The moderate numerical strength would not be unfarourable-rather, perhaps, the reverse - to influence and power, to loyalty of sentiment and to consistency of course.

\section{A. Mumentary Gleam of Protection at Sighlue!y.}

During the temporary displacement of Sir Itenry Parkes's government, just alluded to, the protectionist advocates enjoyed a momentary gleam of hope, and their colours and their arguments were at once displayed.

Let me extract, from the elaborate address of the protectionist premier of the passing moment, Mr. Dibbs, the following passage, which concisely presents to us at once protectionist principle and protectionist error :-

"Almost every other country protects its markets against our competition, while its surplus products and manufactures pour into New South Walesthe market which should be ours, but which we 
mactically hand over to others."-- Sydney Merninu Ilerald, 23 Jan., '89.

Is the protectionist to remain for ever incompetent (1) perceive that the change he would introduce here would be the sacrifice of the society's major interest. for the minor-the welfare of the greater number for that of the lesser?

Let me now reconstruct Mr. Dilils's sentence in accordance with the principles of true economy and common sense. It will then read thus :-

". I lmo-t every other country refuses to its people the selection, which they would otherwiso malie, of such of our products as best suited them, while such of the uroducts and manufactures of these countries as best suit us we are always free to secure. Thus, by our advantageons exchanges of other linds of our own products for these suitalle imports, we make for murselves the hetter market, while the self-restricted ("onntnies in question make for themselves the worse." Had not the colony best remain so ?

liefore concluting here this work, which gives the Australinsia of to-day, and was preceded only a few months hefire by my "Personal Recollections" of the salne part of onr Empire half a century hefore, I an anxious to pay a deserved tribute to my old friend and Victorian fellow-colonist, Mr. James

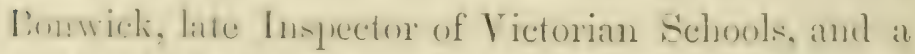
multifirions anthor mpon these Southern coltenies. Not a few of us lave already taken up the pen on In. half of one infint Ifercules at the Antipodes, but 
more laboriously and more successfully perhaps than any other my old friend has toiled to provide the earlier food for the future historians of Australia.

8 Finch Lane, London, W. WEstgarth. 18 th March, 1889. 



\section{O N T E N T.}

Preface . . . . . . . . ili

P A R T I.

Section I.-A Prefatoiny Discussion on the Olimgin and Plan of the Work . . . . 1

An Australasian Retrospect of Half a CenturyClaims of "The Voyage Out" as part of the Subject - Choice of Route - Rival Interests of Routes The American and Mormonism-The British Association to Australia - Some Suggestions on this Subject-Plan of the Work.

Section II.-The Voyage Out . . . . 14

The Charming Canaries - Cape Town - Tasmania.

Section III.-Hobart, the Capital of Tasmania .

Comparative Race of Colonial Progress - A Tasmanian Premier - A Digression upon Colonial Finance - Intercolonial Federation as bearing on Colonial Finance-Question of incorporating Tasmania with Victoria.

Section IV.- Hobart to Melbourne, vî̀ Launceston, Bass's Strait, Port Phillip and WiLliaMSTOWN . . . . . .

The Tasmanian Main Line-Launceston, Second Port of Tasmania - Bass's Strait - Bad Weather -Port Phillip - The Yarra Entrance: "The New Cut" - Melbourne Wharf and Old Friends. 
Section V. - MIelbourne, the Capital of Victoria, IN 1888 . . . . . . .

Mr. Francis Henty-'The Henty Family, Founders of Victoria-Followed by Colonising of Port Phillip by Batman and Fawkner-The Messrs. Hentys' work still unrecognised by the Imperial Government - Melbourne, 1840-57, 1857-88-The Tramways System-Some Peculiarities in Colonial Progress-The Melbourme Press - Melbuurne TradeA Personal Retrospect of Forty Years.

Section VI.-'The Melbourne Centenary ExuiBITION OF 1888 . . . . . .

Foreign Visitors - The Opening Procession - The Cosmos of Exhibits.

\section{Section VII.-Melbourne in 1888 (continued)}

Collins Street, the chief Business ThoroughfareRival Places of Interest-The Benevolent Asylum The Public Library, and other Institutions - The Opening of the New Bridge - The T'own Hall and the 'lown Clerk - The Mayor and the Great 'Town IIall Balls-The Original Melbourne Cemetery and some Old Friends there-The Second Cemetery and yet other Friends-Suburban Melbourne, how changed! - The Suburban Municipality SystemDisappearance of Batman's Hill-'The Great Work of the Melbourne Harbour - A Suggestion to improve Melbourno Improvements - I'lie young P'rince of Schleswig-Holstein, 1850.

Section Vili.-Melibourne to Sydney by RaIl .

Ofticial Cuurtesies and Free Railway Passes Australian Scenery - Dead and Dying 'TimberThe River Murray, and Albury - Colonial WineNew south Wales, and bracing cold. 
Section IX.-Sydeey, the Capital of New Souti WALES, IN 1888 . . . . . . 9t

Comparison with Melbourne-Sydney's Harbour of Port Jackson - Comparison of New South Wales and Victoria - Sir Henry Parkes, Premier of New South Wales.

Section X.-Ay Altogether Ixeritable Digre:sion upon Free l'rade and Plotection in Australasta. . . . . . . 106

Some introductory Principles-Economic Advantace alone dealt with-T'ro Illustrations-The Higher Price and Diminishing Labour - Product under Protection - Competition and Free Exchange Mill's qualified Concession of a temporary Protection - Case of Victorian Candle-making - The Argument with Protectionists-The Conclusion, as I draw it.

Section XI.-Sydery to Brisbane by Sea.

The Nerrcastle Labour Strike - The Winding River-Brisbane.

Sechior Xil.-Brisbare, the Capital of QueessLAND, AND its NeighbOURHOOD • . . 131

Good Streets and Buildings-The Charred and Dead Trees once more - Want of Capital for Land and Mining Derelopment-Brisbane Waterworks.

Sectior XIII-Brisbase to Srdaey by lianlwa 1:S Queensland Traders "threatened" with Protection - Australian Scenery once more - Great Rail Bridge over the Hawkesbury still unfinished.

Section XIV.-Sidney once more, axd the Blue Mountalns . . . . . . .

A very Old Friend - The famous Blue Nountains, and Katoomba Township - Sydney HarbourManley Beach. 
Section XV.-Sidney to Alckland, New ZeaLANd, BY the "Frisco" MATL . • • 150

Grand Sea Approach to Auckland - Climate and various Attractions of Auckland.

Section XVI. - Auchland to New Plymueth, Picton, and Wellington, by Sea. • . 157

The Premier and the New Plymouth HarbourSome new Plymouth Resources - Cook's Strait and Nelson - A natural Harbour in the act of Silfconstruction - The Natives and their Resel ves of Land-A notable New Zealand Colonist-Picton's Fine Harbour and Oysters.

Section XVII. - Wellington, the Officlal Capital of Neiv Zealand . : . . 174

A Visit to Sir W. FitzHerbert-Maori Town Life, and Native Village of Petoné-A Working C'lass Conference - The Great New Meat-Freezing 'Trade -'The Wellington and Manawatu Railway - A Pleasant Excursion.

Section XVIII,-WElington Harbodr to LytTELTON HARBOUR . . . . . . 188

Fine Coasting Steamers-The "Wairarapa "-Some New Zealand Public Men, and the depressed Times.

Section Xix. - Iyteleton Harbour, Littelton, AND CHmistchuRCH . . . . . 193

Christchurch and its remarkable Water Supply The late Earthquake.

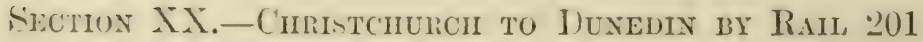
The Canterbury Plains - The "Gorse" - Timaru and its Harbour - Oamuru and Harbour. 
Section XXII.—"The Bluff" axd Ixvercafill, Foveau Straits and Stewart's Island . . 213

A New Zealand Storm - The Bluff Harbour Invercargill, a MIodel Town - Stewart's Island and Foreau Strait, and their Oysters - An interesting Story of Early Culonial Life - Another Talk with Working Men.

Section XXIII.-Retury to Hobart, and once MORE to MELbOURNE . . . . . 228

Section XXIV. - Meebourne to Lilfdale and Fermshaw . . . . . . . . 231

Small Inland Towns, their Similarity-Forest-clad Mountains - An Aboriginal Native Reserve.

Section XXV.-Melbourne to Lancefield .

A Remarkable Colonist, the late Mr. W. J. T. Clarke

- Brewing, and the importance of the Water.

Section TXTi.-Melbourse to Geelona, QueexisCliff, and Ballarat . . . . . 24;

Geelong-Queenscliff - Military Defences - Mrore of the Defensive - Indented Head and Tictorian Agriculture - Geelong to Ballarat - Ballarat A Ballarat Gold Mine - Mayor and Town Hall.

Section XXVil.-A Tisit to Mr. Ellery ayd the MLelbudrae Observatory

Srctiox XXVIII.-A uUch-NeEded Reform

Section XXIX.-Melbourise to Adelaide by Rain 271

A Farewell Address - The Start for Adelaide The Mallee Scrub - The River Murray, the Australian Mississippi. 
$\mathrm{XXX}$

Section XXX.-Adelaide and South Australis

SEction XXXi.-The Australiay Transcontinental Railway

The Chinese and the Coloured Labour Question in connection with this Railway - The Mode of Government of Tropical Colonies - A Kanaka or Coloured Servant in Australia - Interviewing.

Section XXXII.-The sS. "Orizaba": Adetaide to King George's Sound, West Australia 295

Superiorities of our Vessel-West Australia - The Railway from Albany to Perth.

Section XXXIII. - The Vorage Home: IVest Australia to Coloubo. . . . . 300

The Australian Seas-Ceylon and Native Labour - The Humblest may, in his turn, be King of the Situation-Ceylon Features: Trafficking; Schools - Colombo Harbour.

Section XXXIV.-The Voyage Home: Colombo TO ADEN . . . . . . . . 313

Coaling at Aden - Bargaining - Importance of Aden : its various Races.

Section XXXV. - The Voyage Home: Aden to PorT SAID . . . . . . . . 321

'The Red Sea - The Suez Canal - Port Said.

Shethox XXXYI.-The Vorage Home: Port Said to NAples . • • • • • • 328

The End of our Pleasant Voyage. 


\section{PAR T I I.}

General Questions of the Colonies and the EMpire.

Article I. - ON the Prospect for A STILL Improved Service of Intercomandication

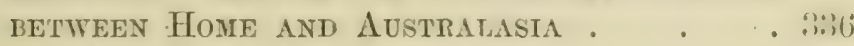

Article II. - On the Amelionation of the $\Lambda$ tistralian Climate . . . . . . 311

Articje III.-The Great Frozen Meat Trade of Australasta . . . . . . . PH

Article IV.-ON the Policy of the Empire's Extenston . . . . . . . 350 Case of New Guinea.

Article V.-Tine Question of Freedou or Riestriction in the Eupire's 'Trading . . . ijti

First Attempt at an Economic Parliament of the Empire-The General Question as to the Empire.

Article VI.-On the Socio-Political Principles of the Eirpire's Government • . . 362 The 'I'ropical Settlements to be under Crown Government.

Article VII. - On Inter-Colonial Federation; or, the Union of Natural Colonial Groups into one Sub-Imperial Power and GoverxMENT . . . . . . . . 36ij

The Australasian Case-Guidance of the Canadian Case - Exceptional Cases - Queensland - Modes of Procedure towards Federation-Chief Difficulty that of the Differing Tariffs - Great Advantages from Canadian Federation-How the Australasian Tariff Difficulty may be met. 
Article Tili.-The Uyity of the British Eurpire

Definition of the Case - Defects of the Present Situation - The Right Hon. W. H. Smith on the Unity of the Empire - Inevitable Tendency of the Present Relations - Some Colonial Prospects, fanciful and otherwise - The Unity aimed atForeign View of the Question - A Public Discussion in Melbourne - Some Reflections - Consideration of Methods for uniting the EmpireThe Cabinet, plus Colonial Representation, as the Empire's Executive - Postscript: On the Present Colonial Relations as a supposed Basis for Irish Home Rule - A Colonist's View of the Irish Question.

Article 1X.-Suggestion of a Monarchic-Democratic Pferage of the Empire . . . 393

Article X.-The Mount Mongax Gold Mrne • 401

History and Description of the Mount - Estimate of the Gold of Mount Morgan - How the Mount was produced - Effect upun tlee World's Market.

APPENDIX . . . . . . . . . 413

IXDEX . . . . . . . . . 4 415 


\section{HALF A CENTURY}

OF

\section{AUSTRALASIAN PROGRESS.}

\section{PART I. \\ SECTION I.}

A PREFATORY DISCUSSION ON THE ORIGIN AND

PLAN OF THE WORK.

An Australasian retrospect of half a century.

Mr title grasps a stretch of the past which in these days of progress must involve a vast diversity of conditions - the earlier from the later. We are often saying, as we look at the rapid competitive derelopments, for instance, of modern commerce, what will they attain to half a century hence? But it is hardly less interesting to look at what the position of to-day sprung from half a century ago. By duly considering that, we may better estimate the lialfcentury to come. My retrospect does not quite complete that considerable section of time, but it is so near to it as to justify my title. I left Home for Anstralia in July 1840 , and I have just returued from the latter, and for the fourth time in so many Home revisits, in Norember 1888. 
It is not easy for a London merchant, in a fairly full ticle of business, to alssent himself for so considerable a holiday time as a visit to Australasia requires. But, with a reliable junior to leave behind me, I had made up my mind that, as far as depended on myself, my old home must be revisited before I left the morld, and I only waited the best opportmity. That was supplied by the grand Centemnial Exhibition at Melbourne, which was to open there on 1st August, 1588. I took my measures, therefore, so as to place myself in Melbourne on or before that day. My wife and daughter were to accompany me. The former was already an old colonist, having resided with me, after our marriage in 1854 , from October of that year to February 1857 , when, upon business calls, I had to leare the dear Colonial home, with its pleasant climate and its many social intimacies, and to take up iny quarters in the great world centre, London, where I have since remained, minus the five months' revisit just completed. I am not by any means to pose as the martyr under this Australian deprivation, for either extremity of our great empire has its own array of attractions, and, if each was taken "for all and all," it might lie difficult to adjudge the palm. Thus to my wife and self our trip was a renewal of acquaintance; but to our daughter, who was just to enter upon what the other sex call the majority, the whole was an entirely new world, the marrels of which she might in many respects appreciate.

I was not to revisit Australasia for myself alone. I contemplated taking the public with me, by the 
short and handy roal of a volume of the results. The leisure of a long voyage has always been attractive to me for writing a book, and in this way, in my several royages, I have got through several volumes. On the way out, on this very occasion, I wrote a small octavo of "Personal Recollections of Early Melbourne and Victoria," which, to my great reward, proved very acceptable to old colonist frieuds. And now I am just completing the work of the return voyage, with the title of ambitious grasp to which I have already adverted.

\section{Claims of "the Voyage Out" as part of the subject.}

Well, I must begin my IIalf Century of Australasian Progress with "The Voyage Ont," if only because the progress in that respect is hardly less, if indeed at all less, than in any other. My outward royage in 1840 was in a ship of 414 tons, which took 143 days to go from Leith to Port Phillip. My return voyage, this year of 1888 , by a steamer of above 6000 tons, requires but 38 to 40 days. Indeed the protracted time of my first royage is enough now, with all the advanced facilities of intercommunication by sea and land, for outward and return voyage, and for a visit, such as I have just paid, to all Australasia.

\section{Choice of Route.}

Our purpose determined, the first question was the choice of route. Here was quite an embarrassing quantity. The venerable "P. and $\mathrm{O}$." which no 
doulst most of my readers linow to be the handy abbreviative for the great Peninsular and Oriental Steam Navigation Company, came up, of course, first to our minds, more especially as I have the honour of some old friends in its Directorate. Driving on its heels came up next the interloping Orient line, which, with all the energy or impudence characteristic of the new hand, had bid fair to beat the old one in its work, until, stung beyond endurance at such insult, the old lion rose in his strength, and lamelied recently his crowning triumplis. These were the "Victoria" and "Britannia," followed, in gallant succession, by the still more superb "Oceana" and "Arcadia;" these, again, being even eclipsed l,y the "Peninsula" and "Oriental." And, next, the Messageries Maritimes offered a pleasing and picturesque, although a slightly circuitous route, rî̀ Madagascar, Seychelles, and our still French-speaking Mauritius, but with a high repute as to matter's of personal comfort. These were all "riu Suez." But my wife had constitutional objections to the Red Sea, in spite of all Scriptural and classic attractions, and most especially in summer. Te might indeed return by that route, confessedly the most varied and interesting of all, because that would be at a time well into northern winter. And we did, in fact, return by it per the Orient line.

Of the regular lines there remained five more, hesides, perhaps, an endless issue of irregular lines, and individual vessels. These were: the San Francisco line to Auckland and Sydney, cia the United states Interocennic Railway; the new rival Comadian 
Pacifie line, riu British Columbia ; the New Zealand Shipping Company, a Royal Mail line; the Shaw Sarill line also to New Zealand, via IIolart, where we could be landed with prompt facilities to reach Melbourne, and the Queensland line, a branch of the British India Steam Company, via the interesting lut rather tropical Torres Straits. 'This last was dismisserl along with the other Red Sea routes. The American was interesting for many reasons, including a passing stuly of Iformondom on the spot, and a glance at the Yosemite Valley, and at much else worth seeing, if we had only had more time at our disposal. The Canadian Pacific, although of stirring interest to our empire, and a marrel of the most recent British effort of that kind, was only in the throes of a commencing existence, and not yet reliable so as to meet precisely our allotted time. We decided for Shaw Sarill, and took our passages by the s.s. "Coptic," Capt. Burton, 4400 tons, to sail from Plymouth 16th June, and land us at Hobart, Tasmania, providences excepted, on 27 th July. From Hohart we expected easily to reach the grand Melbourne show in grood time for the opening.

\section{Rival interest of Routes-The American and}

\section{Mormonism.}

I had hoped to make the American either my outward or my homeward route, as there is, as I have said, so much to see and compare in that rast country of not less rast modern progress. Not the least of my interests there, howerer, concerns a section of "progress" which is not of the ordinary 
kind, although quite as interesting and perhaps as important in its way, as any other.

I have, in short, taken much interest in MIormonism, because we see in it a system which, whilc it may possibly survive to be one of the faiths of the earth, is now in the very act of its genesis, and in the instinctire act too of building itself up into a separated religious existence. I had been making my notes on this new faith, in the hope of afterwards instituting a comparison upon the spot. Although this has been as yet denied me, I venture upon a few ideas on the subject.

When some approach to a public highway had been trodden out to far-off Utah, missionaries of various Christian bodies ran in all haste, from far East to far West of their vast country, believing that the manifest nonsense of Latter-day Saintism could be at once dissipated by Christian argumentation and common sense. But, nothing loth, the Mormons, some of them already "born in the purple" of an inherited faith, faced about on the enemy, meeting him on the argumentative ground of his own choosing, and utterly routing him, if at least we may judge from the fact of that mode of extirpating Mormon error having never since been resumed. This victory was, doubtless, on the principle that those who have got farthest in religious extremes are ever the most practised and adroit at argumentation, and that the most effective way to silence a zealous and extreme sectary is to bring against him some other sectary still more zealous and extreme. 
Mr. Froude condemns the persecutions to which the Mormons have heen subjected, and which, as he thinks, perhaps rightly, have been the rery life of the new faith. But his own seathing sareasm, poured upon the lead of that very prosiac mortal, sensual rather than sensuous, Joseph Sinith, the public-house kreper, to the effect that the snirit within him was chiefly that which he got from his own bar. is only a different form of the persecution which he condemns. Not only will this mode le as ineffective in its object as the other, but, in its coarse, indiscriminate way, it explains nothing, and gives $n o$ help to a philosophical solution.

Smith appealed to the infinity of variety in human nature, and a few individuals, out of a few millions, responded. "Ce n'est que le premier pas qui coûte." His religion was already born. The Book of Mormon and the gold plates hare already passed their ordeal, and entered that "dim religious light," in which, however, "the Church" can always see clearly its own traditions and miracles. Had Smith been a purer-minded man, the plural wife would not have occurred to him. Heaven would have made a different lind of suggestion towards that instinctive aim of "differentiating" the new religion. But this particular outcome of the "chapter of accidents" in the faith may either break up the Saints by conflict with their general government, or break them down more quietly upon the issue of the false moral of the "plural wife" system. Indeed, in riew of the latter defect, a great church is hardly passible to the future. 
Other thoughts on this differentiation instinct are still afloat, as we may hear in the addresses, sanguine, ambitious, or fanciful, as to here and hereafter, of the lolder Mormon missionaries, seeing that the faith has not ret been erystallised into a final gathering-up creed. It will be indeed a curious study to see in what directions human nature essays to take departures from that moral climax which has heen generally conceded to the Christian standard by the moral sense of the world.

Joseph, as Mr. Froude tells us, is already reverently called "the Prophet." But the prophet must have prophecies, and these graduate into other miracles. In fifty more years we shall have a life of Smith wholly miraculous, based partly on simple ficts religiously developed, partly on the purely imagined, ereated nobody lnows exactly how, or when, or where, but always under a general disposition within the Church, to receive rather than to criticise, while the "Church Historian" complacently supervises the whole promising field.

It is to time, and the reverent look back upon the dim past, that we are indehted for these wonders. The late President Brigham, who was, in his rough way, the very incarnation of common sense, used to laugh at the ascription of the miraculous to himself, saying that all was due to judicious use of natural or acquired sagacity. But none the less, Brigham has already ascribed to him his own category of revelations and miracles, almost as much as to his senior, Joseph himself. This doughty vicegerent of

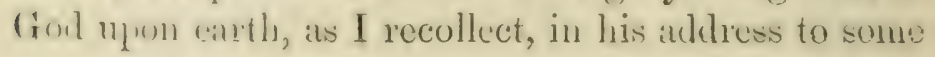


foreign Mormon immigrants, exhersted them to leain learning English, for English, he said, was the langnage of Hearen, and should he known to every Mormon. But what would arail all of Profesion Max Muiller's scruples on this puint? Mrighlann s ready humour and resource would have been bronght up to rout, if indeed worth the while, the man of mere science. But the Prophet Priest and licrelator of Heaven might have held himeelf above this necel, even if he had felt that for once at any rate he had made an ordinary nortal's nistalie. He mighit, with customary theological atroituess, have mate out that the pure ante-deluge English, broken up and lost at Baluel, hatd reviven in the Ifelnow and old Sixon black letter, so much alike, ard eventuated in that restoration of the original English, as spoken above the clouds, which has now in these latter days greeted the birth of the True Mormon Church. This would have been quite as satisfactory to Mormon believers as the eleren witnesses to the gold 1, lates, and the evidence that the present American Indians are the lost ten tribes.

Then, finally, comes the delicate question of the "conscious impostor," in these busy malings of new divinities and new religions. Certainly the naked term is rarely applicable; lut as certainly, if we could but see or know, in a way that "the powers aboon can only ken," we might discurn a very slifty ground between the conscious and the unconscious. Even the terrible Momntain Meadow massacre, for which the Mormon Bi-lnol, Lee was executed by the Lnited states Goremment, including the pitesus 
case of helpless women and young children, or the utterly merciless atrocities of the "Danite" Rockwell, may hare to be thus specially judged, as incidents which have at least their general analogies. Religions feeling, even in more generally accredited quarters, is apt, in its alliance with human nature, to take terrible sweeps to the left, in alternation with its more normal and usual course to the right. Only some few year's ago, a company of Paris nuns, those leings of angelic devotion to lumanity in such countless instances, were found to have deliberately, and by their own personal action, roasted before a fire, to utter disfigurement, the face of one of their servant girls, as the punishment for some petty theft.

\section{The British Association to Australia.}

From this long digression, upon, however, an interesting philosophy, let me come back to my subject of Progress, and still that particular section of it which concerns "The Voyage Out." No more striking instance of that i rogress could be adduced to-day than the fact that a visit of the British Association to Australia is a thing now "quite in the air"; nay, more, that the invitation will probably come off all but immediately. After the fears at first, and success eventually, of the meeting at Montreal in 1884, which, as an old life member, I liad the pleasure and profit of attending, there naturally follows, in this age of progress, the meeting at sydney or Melbourne. Nuch interested as I was in this question, I did not let it rest after I had stepped once more upon Australian soil. Indeed, as my 
friend Mr. Service, the ex-premicr of Victoria. reminded me, the invitation had been actuilly sent Ilome several year's ago, when the spirit of "thlat sort of thing" was alive, under the prospect of successive grand Exhilitions at Adelaide, sychney, and Melboume. The latter city sent the invitation; lut. as it was for the very next year, it had to be declined owing to a pre-engagement. Afterwards the New South Wales Goverument proposed to invite, not the Associatiori, but some fifty of the leading seiencemen, who, with passages paid, were to grace their Centenary Exhibition of last year. But, through. some political party " cross-grains," the money was refused by the popular assembly, thereby teaching a lesson that such cross-grains ought always to be, as they mostly easily may be, provided against, by a little care in the right directions."

\section{Some Suggestions on this Subject.}

It is fortunate that the Melbourue invitation froved abortive, both because a longer notice is needed, and because Montreal and other experiences have taught some good lessons. I consider that an invitation should contemplate four clear years, as that interval is needed to enable our busy merchants and others to look long enough in the face so protracted a holiday-making, as well as to enable the competitive shipping to put furth all the strength of

"The break-up of a great "land boom " at Melhume, which was in full swing during my late stay there, may have put quiot matters of this kind out of the popular mind for the present. 
their day in a royage, and upon an occasion, that will certainly mark an era in the great Australasian group, if not indeed in the empire itself.

Our experience in this matter takes next another direction. Canada contributed $£ S$ per head towards the passage-money of every Association member crossing the ocean on the occasion. This might me:m, relatively, at least $£ 20$ for Australia, so that, in $m y$ discussion of the sulject with some leading Victorians, they seemed overwhelmed with the abyss of expense to which they might possibly be conmitted. Now I am sure that any one who thoughtfully regarded this case, so as to deduce, as I had to do, that one half or more of the company, not howerer by any means quite regarlless of science, were yet mainly bent upon a pleasure trip, reached the conclusion that most of this Canadian money was really thrown away. Counting heads in a case of science is even worse than in a case of democratic politics. Secure the men of science, and the others will follow. But those who have the fullest heads have not seldom the emptiest pockets. I conclude that the men of science only should be paid for, and that ly a full free passage. The rest of us will take care of our:elres. And thus some trifle of 25000 may be all that is neerded.

\section{Plan of the Work.}

And lastly, as to the plan of my work. How should accomits of Colonies, young and ever-changing Culunies in particnlar, le written? In five diflerent rolumes which I hate successively issued I always 
treated my sulject "historically." That is the way. natural to one who sets about his work in business fashion. He tells the listory, and sets it off with abundant statistical illustration and proof. "Very grood," say most of his audience interested or appealed to; "possibly an excellent bouk of reference, and when wanted we shall look into it." Ife therefore misses being read, except in the aforessid partial or fitful was; and this is surely a most important part of the calse. Five different experiences thus decided me against the historical and statistical-so much so that I resolved, that from first taking up the pen, to finally laying it down, I would not look into a Colonial statistical book or table.

The way for me was thus cleared considerably. Why not, said I, take the Colonies just as they conne before you in your scamper through them? You may have indeed seen them only meagrely, but descrilue what you have seen. Tou may give no bad idea of a Colony liy a description of its chief town, or of some excursions into its interior. This, then, is what I decided to do. And, further, I propose to supplement these sketches by some more comprehensive general views and considerations as to the Australasian Colonial group. Its Colnnies are mostly vast States of themselves. Collectirely they have nearly the area of Europe. They are rapidly rising up in rast importance at the furthest corner of our Empire, and science and enterprise are every year reducing the disadvantage of mere distance, and preparing for the United Empire which has latterly taken such hrold upon the national mind. 


\section{SECTION II.}

THE VOYAGE OU'T.

LeArtag Plymouth, with its raried scenic beauty, on 16th June, we soon "homed" ourselves in the "Coptic," under the gentle pressure indeed of the assisting consideration that this must needs be our home for the next six meeks. We got through the Chinnel and Bay of Biscay with decidedly superaverage good luck, and, after rather more than five pleasant days, reached the Canaries. The passengers had made mutual acquaintanceship by this time. We were a rery good and sociable lot of passengers, including the distinguished company of Lord and Lady Alfred Churchill, the former, ageing and considerably broken down, being on a tour for health. Lord Alfred was already an old Victorian Colonist, whom my wife and I had met at Governor Hotham's table no less than thirty-three years ago, after his arrival from a rather adventurous voyage in so small a ressel as his father's yacht; and I had met him repeatedly since at home in his caplacity of President of the Society of Arts, and otherwise. His health object was certainly gained, for we left lim at IInlart a comparatively robust man.

So much for the social agreeables of our passenger case. There were, however, several young 
lads of the party who, particularly towards the end of the trip, took rather heavily to the bottle, and gave our good captain some trouble-fine young fellows they mostly were too, which made us all the more regret their wretched taste. But, after all, they came more in our captain's way than our own. We heard a flare at times in the smokingroom, but all was suppressed into propriety hefore the other passengers. We made one great social hit. The routine four-o'clock afternoon tea of the calin we converted into "the salon," and the salon, under one or more of the ladies, became so pleasant an institution, that at last we would linger a gorol hour over it. Thus this was one of our notable time-killers.

\section{The Charming Canaries.}

Those charming Canaries! what a climate! what beanty! Although in the middle of the summer, and in latitude $28^{\circ}$, there was a fresh, cool seabreeze, as though we were sniffing a pleasant midsummer air in Deroushire. Is it disloyal to our now peace-seeking Empire to sigh for an exchange of these "Fortunate Islands," these ancient Isles of the Blessed, for our now meaningless Gibraltar? What might be the consequences? We would have henceforth the best of all fortresses in the hearts of the Spaniards, while, on the other hand, the Islands, under us, would quadruple their importance ere the end of the contury; so that, if Spain still kept, practically, a share-and-share-alike partnership 
interest, freely to be accorded her under our trading freedom, she would net 100 per cent. by the transaction, with "the Rock" into the bargain. We, indeed, should gain infinitely more; but that is of the nature of beneficent commerce.

We anchored off Santa Cruz, the capital of Teneriffe, and had time for an interior trip to Laguna, six miles off, where we found a considerable town, nearly one half the size of Santa Cruz, a good hotel, with "English spoken here," and the ineritable "Cathedral" of every Catholic place. We were on the watch, of course from the first, for the grand Peak, so often under his cloud envelopment. But he remained in pertivacious retirement duxing our stay. It was only after we were some twenty miles on our sontherly way that his grand form rose against the clear sky. We had no hot weather "to speal of," excepting between two and three days in passing between the Cape de Verdes and Africa, where, being so near the latter (about fifty miles off), the thermometer went up to, and a little over, $80^{\circ}$.

The Cape came next in its due time, and as I neared its lofty scenery, and, when still closer, was greeted by the English voice, I began to realise what the British Empire was, and what a status it was to be its citizen, fecling one's self at home in every quarter of the glole. This idea was still cxtented when, on the night of the 2Sth July, we dropred anchor moler the expansion of the lights of Ilethrt, and were saluted once more by a babble of English from surrounding boats. 


\section{Cape Town.}

We had a few hours in Cape Town, a considerable place of between forty and fifty thousand people. hut the very poorest specimen of a town of that population which I ever met with in our Colonies. Jint this is readily accomnted for by the kind of its population. Almost withont exception the entire working class is non-European, and cmisi-ts of the oddest diversity of human skin, and human feature that any one could imagine. The halitations of these people were of course "liothing particular," and the nigliye in that respect had descended to the streets, not one of which, as seen by us at least, hard a cuntinuous foot pavement, or was even completely macalamised. There were some fairly good business buildings, the Standard Bank being one of the best. Govermment House and Parliament House may just pass.

Art was decidedly inferior to nature. The grand Table Mountain reared its solid black form immediately behind the town, the black leing often set off by a white topping of clouds called the tablecloth. The height of about 4000 feet is almost that of Mount Wellington, which rises, not altogether dissimilarly, close behind Hobart. We regretted our inability to go even the short eight miles by rail to Wynlerg, down south towards False Bay, where there is much more momutain beanty, many vineyards, and much wine-making.

Our only storm was for a couple of days, in trarersing the broad L'ilgulhas Bank, which, as our 
captain said, although sixty fathoms under water, somehow contrives, on even slight excuse, to kick up a storm on the surface so far above it. For a week afterwards we had abundant company of allatrosses and lesser birds, which occupy Kerguelen's and other smaller isles and rocks hereabout for their breeding.

\section{Tasmania.}

On the morning of the 27th July, fair Tasmania saluted us from afar; and as we came nearer we had a home reminder from the snow that was abundantly sprinkled on the southerly slopes of her hills. We shortened our route a few miles by taking D'Entrecasteaux Channel, being thus the first, or at any rate the second, of the larger shipping, direct from Europe, which had done so. Darkness orertork us as we were making our exit from this narrower channel into the ample bosom of the beautiful Derwent, the pilot having just previously boarded us. 


\section{$(19)$}

\section{SECTION III.}

HOBART THE CAPITAL OF TASMANIA.

Wrine still at sea, we might have revelled in the idea that, once arrived at Hobart, after so long a voyage, we should forthwith rush ashore, and revel in the reality of terra firma. But we did no such thing, ladies and luggage being one chief part of the question. We slept peacefully and contentedly on board, took a quiet breakfast, and towards ten o'clock were ready for shore. The "Coptic" had anchored two hundred yards out in the stream, so we took a boat, and were soon enabled to step out upon Australian soil.

Hobart was an old friend. This was my fourth visit, beginning so early as January 1841. Every old friend of the other lind there had passed away. I recognised, however, some of their houses, amongst them that of Mr. Henry Hopkins, an early and prosperous merchant, who had what was a palace in the early times, but which was now a private hotel in its good situation in Elizabeth Street, kept by a namesake and old acquaintance of mine, Mr. William Westgarth, late of Melbourne and Sydney, and which he had now re-named Westella. We went to Westella for our one day's stay, and our friend there, who, fortunately for us, was in the midst of his leisure season, did his best to show us his fair city and its picturesque surroundings. 
To ascend IIount Wellington was no possibility for ms, eren if we had had the time, as his snow-clat crown indicated difficulties needless to be ficed in pleasure excursions. Besides. fur my omm part at lenst, I had already made the ascent, some thirtytwo years liefore, and in rery pleasant compuny ton, namely, that of $\mid$ my old friend the late Mr. Willian Rubertson. of Hobart, and of Lake Colac, Tictoria. It was at a more propitious season ton. and through the clear air I surveyed the plain to the north, bounded hy the Derwent, as though it had been a map) sketched upon the earth's table. The rourls locked like white lines in the sunshine, and upon one of them a stage coach, which happened to lie crossing at the time, seemed like an ant crawling, with unnsual deliberation, along its prescribed line. But we realised something of the winteriness we might have now encomitered on the mount hy indulging in a drive for some miles along the Inon River Road, in some of whose hill-surrounded valleys, screered from a sun, warm even in winter, we encountered on our way as good a paring of ummelted snow as might satisfy a Scotch Highlinder for his New Year's scenery. We duly risited Furntree Gully, one of the sights of this locality.

There had been an unusually coll winter here, and not here only, but northraids, as we afterwards experienced, also at Melbourne, and even still nearer the tropics, at syduey. When, on the morning after arrival, I took niy regular prepundial walk, I fomed the Iobart strects bound up in hard frost, and the gutters, where there were any. corered with 
quarter-inch ice. But the sum in the bright sky was already warm, and dissipated the cold enemy wherever his rays could penetrate.

One of our calls wals at Govermment Honse, as we were armed, ly friends at IIome, with introductions to Sir Rolier and Lady Hamilton; but, as her ladyship, who alone was within, was already engaged with the Churchills, we improved the too hrief hour ly passing into the adjacent Botanical Garden, and the less regretfully, from learning that we should next day accompany our new and distinguished friends acress the Island and the Straits, to the near aplroaching opening of the Exhibition at IIelbourne.

\section{Comparative Race of Colonial Progress.}

()ne of the features of these Southern Colonies, which I shall have repeatedly to allute to as having struck me both decidedly and unexpectedly, c:nme upon us ere we had been an hour in Hobart. Miss Westgarth, our hostess, entered our room to say that the Tasmanian Premier wished to speak to me. "Bless me," thought I, "this is quick work. Is he outside? pray show him in." "No, sir," was the reply; " he is speaking to you through the tclephone." So I hied at once to the telephone room, and duly, as directed, put two wire-connecterl caps to nyy ears, and was all attention. I did har a still small roice come up, as from the rasty deep; but, whether from some little deafness of age, or from the atre-inspiring of such unaccustomed thing:; I firiled to make it out. and willingly relinguished 
my post to Miss Westgarth's more practised head. Thus a meeting was arranged without personal fatigue or the loss of a minute of time. I bave no recollection of telephoning in this every-day fashion at Home. Our daughter colonies out here are in a faster race in many respects than their old mother.

\section{A Tasmanian Premier.}

I did expect some word from Mr. Fysh, whom I had before met in London. One of my amateur missions, if I may so describe it, was on the question of Australasian finance, in which, as a subject iutimately associated with my business in Colonial securities, I must needs, if I were at all worth my salt, be something of an authority. It was an easy and pleasant office to point out the suitable and unsuitable in Colonial Loan issues, the former involving 1 or 2 or even 5 per cent. and upwards of relative advantage to the issuing Colony, and soon accumulating to hundreds of thousands of pounds sterling of differences of result. The rising credit of the Colonies, and the lowering tendency of the Home money-market, had worked marvels to Colonial loans. Tasmania is still paying 6 per cent. on the gradually expiring engagements of her first loans a quarter of a century ago. She has been down to 4 per cent. for a good number of past years, and now the question is for 3 per cent.

\section{A Digression upon Colonial Finance.}

The technicalities of our IIome Market in such thing's as Colonial Loans need a voluninous explan- 
ation to any one who can patiently stand to have it all out. But I will better satisfy the ordinary reader, who does not wish to be just totally ignorant of them, if I briefly sketch them in the general, without descending to minute detail. My recommendation was, that all these Colonies should agree to issue 3 per cents. As additional inducement, Mr. Goschen had just cleared an extraordinary vacuum in 3 per cents, so that countless widlows, and suchlike dependent people, were ready to jump at any new bait that might be at all reliable to replace the old.

In coming down to a lower interest rate, there is more, speaking as from the market, than meets the ordinary eye. A law of our market, as sure as the financial human nature it is based on, is that a discount stock sells relatively higher than a premium stock. Suppose the "actuarial" value of any 3 per cent. to be 90 , and of a 4 to be 110 ; then, instead of the prices in the market being respectively 90 and 110, while the 4 's were at 110 , the 3 's would be at $92 \frac{1}{2}$, or possibly at as much as 95 . Of course, then, when a stock's ralue rises towards "par" or 100, a lower interest rate should, for any future loans, be resorted to.

Again, the "marketability" of a stock deperuls mainly upon quantity, so as to keep it always in the market. Thus Consols, in their hundreds of millions, were always readily saleable, and were a huge convenience to bankers and other's in consequence. Lest people should be incurably apt to fincy marketability to be due to quality, let me mention 
that the old Turkish 5 per cents., sheerly from their quantity of fifty to sixty millions, were alike me of the most marketable and one of the least esteemerl stocks in the London market. Thus such marketalility comes, from its great convenience, to lave a distinct value of its own, additional to that arising from quality ; as much additional, perhaps, as 1, 2, or even considerably more per cent. Colunial policy, therefor', is to consolidate all del,t amonnt into one uniform stock. so as to confer the highest marketability possible to each case.

Bearing these main principles in mind, the mission which, inter alia, I gave myself was to imluce all these Colonies to quit 4 per cunts., which in most cases were long since at a good preminn, and all go "solidly" for 3's. In one case, that of New Sonth Trales, $3 \frac{1}{2}$ per cents. harl been issned smine years before; but these, begun at abont 90 to !). were nuw substantially orer par, and thus amenable to our aforesaid law.*

* Qneensland, during my absence, brought out also a $3 \frac{1}{2}$ jer cent. in the London market, for which she got only a little over 95 ; but this stock has now advanced to upwards of 100 . Virturia alis, lats more recently intimated that, foilowing New Sunth Wales and Queensland, she is to bring out a $3 \frac{1}{2}$ per cent. luan early in 1889. As Victoria's high credit will command a premium for $3 \frac{1}{2}$ per cents., she would assuredly have realised relatively more for a 3 per cont. Her credit being equal to that of New South Wales, whose $3 \frac{1}{2}$ per cents. are now at 106-during a more fivourablo state of the London market they wero lately at a still higher price - 1 estimate Victoria's relaţive loss, by issuing $3 \frac{1}{2}$ instead of 3 ler cents., at not less than 2 ! per cent., or $£ 25,000$ per million of the $£+, 600,000$ proposed to bo issued. This 


\section{Intercolonial Federation as bearing on Colonial Finance.}

There was still annther point. These Colonies have had before them for half a generation the: question of Interfecleration. Conferences have sat upon it, and it still remains a question unsettled. although, if donl, as to the advantage hat lingered in any mind, the succesiful example of the Cinathan Dominion shonld dispel it. One may moralise on the difficulty of moving man, as a society, compancul with man as an individual. If the latter were offered, on the one hand, a thousand pounds. and on the other a hundred, can any one doul,t as to which he would talie, ant take right promptly too? But the individual and the society, or aggregation of indisiduals, will act quite difierently; and thus we still hesitate and liaggle over the Federation, when every individual thin ks that, as regards himself individually, he would prefer it. I was alout to add that these Colonies' "Protection " tendency is only a variety of the same illustration, for the society, which. as said, is only a congeries of the individual, thwarts

delay in beginning the issue of the "inevitable" Threes is the more to be regretted, as Tasmania was ready, and probably South Australia would have joined, to make up with Victoria the inauguration of 3 per cents, in the London market, in a marketable quantity. Mr. Bird, the 'Tasmanian Treasurer, writing me on 3rd November, 1888, says :- " Your remarks in the Sygdny Ifruld on the consolithation of stucks further confirm me in the belief that 3 per cent. stock is what these colonies should agree to at once." If Tictoria persists in the $3 \frac{1}{2}$, the term should he as shurt as pussille, say mint urer 20 years, which would reduce somewhat the above luss. 
the free action of the latter in seeking the most advantageous economic course. But for this latter question I am not yet ready. I shall return to it in its proper place; I in no way mean to evade it.

To return to this other point, towards elucidating which, however, the whole preceding paragraph will help us, the reader may already surmise the bearing of a federated Australia, or Australasia, upon the finance question. Since the Federation of Canada, imperfectly begun as it was twenty-one rears ago, and now just on the eve of perfect completion, the ralue of the "Dominion" stock lias risen by 25 per cent. above that of eren the best of the previously separate Canadian Colonies. Te must not, of cours, put the whole of that great rise to the one account only, for increasing colonial credit, together with decreasing money interest at Home, may very fairly divide the total. Canada has anticipated her southern sisters in the 3 per cent. race, her first issue, amounting to $£ 4,000,000$, having been sold by public tender, the usual mode in London, on the 16th June last, the day I left for Melbourne. The price realised was the highly satisfactory one of $95 \frac{1}{2}$ to 96 , upon a minimum price moderately put at $92 \frac{1}{2}$. That result was decisive as to 3 per cent. for Australasia, because Australasian resources and prospects have been, for at least twenty years past, viewed in the London market as decidedly in adrance of even those of Canada. In fict, up to within the last ten or twelve years, when the federated Dominion, with its inaugurated Pacific Railway, hrought it to the frout, the stocks of New South 
Wales and Victoria stood higher than those of Canadia; so that the 3 per cent. stock of an Anstrallasian Dominion might now bring a still higher price than that lately realised by the Canadian.

It is not now difficult to infer the bearing of all these considerations. Federate, $O$ re Australasian sisters, and take the grand financial position awaiting you. "We cannot do that at present," they answer, "because, while, admittedly, our respective tariffs are all in a jumble, without general principle or inter-colonial concert, yet each Colony is most unwilling to give up its own particular tariff work." Then federate, subject for a time to the reigning tariff freedom, I answer. Each Colony of the Federation might reserve its tariff in the charge of a commission of its own for after arrangement. In the mean time, issue, all of you, a 3 per cent. in identically the same form, excepting that each Colony issues its own stock on its own responsibility. This will make a stock which is more marketable in each case, besides that such co-operative action will undoubtedly appear to the home capitalist and investor as the first step towards an Australasian Dominion. Sir Thomas McIlwraith, the Queensland premier, suggested a provisional further step, namely a financial Federation, by which, while the more complex political federation of necessity stood over, the Colonies might enjoy at once the higher funancial status awaiting only their own will and pleasure.

Basing upon these contingencies, I constructed the following table; and, as it is not only very short as well as surpassingly important, but is also the 
only statistical intrusion of the lind in my volume, I may hope for the reader's forgiveness :-

Column A gives the price which any unconsorted 3 per cent. now issued in London would bring to its particular Colony.

$B$ the price if all issued exactly the same form of the Stock.

C the price if only federated financially.

D the price under complete political Federation.

E the price after some interval, saly two to three years, when the investing public better knew the stock.

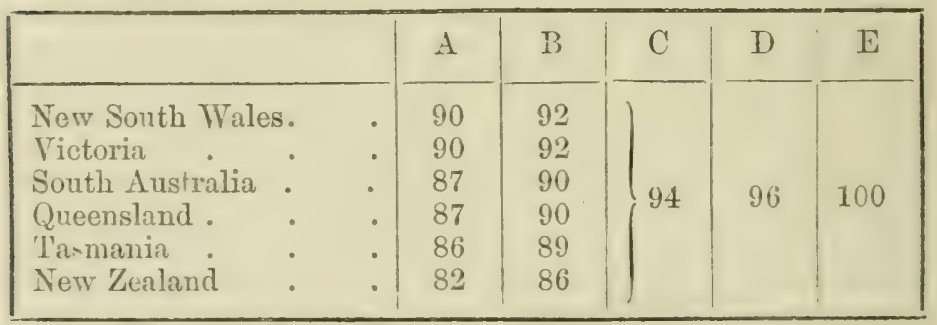

One difficulty which I found in the way, particularly with the governments of the two leadirig Colonies, was a seemingly incurable suspicion that, in lringing up the weaker, the stronger Colonies must of necessity be dragged down. But there is all lut the certainty of a "law" in our market, that the increased political strength and consideration of the ('olonies, and the increased marketability of the combined stock, would result in advance of value in every case, although, no doubt, the weaker would lenefit relatively much, indeed in some cases very much, better than the stronger. 
Imleed, this principle might posilly receive. some diy aliead, a curions and perhaps in some quarters, unexpected extension. Supposing, as we must all hope. that not only the Colonial gronpe. like Anstralasia and the Cape, will he respectively felerated like Canada, but that the entire Limpire will come, in some like way, into unity, the puesticn might arise, nay, would certainly arise, as to there leing lut one stock common to the Empire. Whlat position, then, as to ralue would that comlined and culargenl stock take in the market, relatively, let us ary, as to the positions of the two different stocks of which it was compounded? Our venerable Mother would probably not be quite prepared, possibly she might just at first be a trifle luffed, at the answer of the market, an ineritable answer, as I incline to regard it, namely, that her own great stock. as well as that of the Colonies, wunld lie sulsstantially adranced by the junction. Assuming that

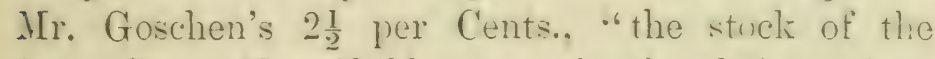
future," as Mr. Childers previously christened it, was to range between 98 and 99 , which seems perhaps the present promise, an "Empire stock" would certainly go up to, or even over, 100. A simple Colonial $2 \frac{1}{2}$ could hardly be put at over 10 ; so that, between IIother and Colonies, the latter has decidedly the best bargain; but the point none the less is that the daughter's can also lift up even their weighty Mother in the value work. Indeed, this is the sort of sledge-liammer argument that, in the practical politics of the time, and in the contingency specified, would probably bring about the result. 
But the loans of the future, in that case, would be all Imperial issues for Imperial purposes, so that the Old Lady of Threadneedle Street would have no need to administer again a quiet back-hander to the Queensland of the new refime, or the Stock Exchange to rough-handle ever orer-borrowing New Zealand.

This is, I almost fear, an unforgivable digression, because it is upon a topic so very dry to most readers. But this outpour of wrath at the first will save much recurrence to the same sort of offence later on, when I had occasion to "interview" premier after premier, in order to persuade them, not always without difficulty, to agree to accept, at 3 per cent. instead of $3 \frac{1}{2}$ or 4 , the money which their respective Colonies had occasion to borrow in the London market.

\section{Question of Incorporating Tasmania with Victoriu.}

Tasmania has been, commercially at least, rather shunted to one side of Australasian progress. She has a surpassing climate, and a full share of physical beauty, but she is small-only about Ireland's sizeand without much of fertile land. To be sure she has yet almost a full chance of mineral wealth, for the heavily timbered and poor soils of her western areas are hardly yet explored, and Mount Bischoff, which was amongst them, has already turned out great wealth of tin. But, altogether, the subject and its prospects are so puny, and the shadow of great Victoria across the Straits is so preponderating, that a surrender of existence has been largely spoken of -a surrender which, if accepted at the other side, 
would make every present modest Tasmanian a proud citizen of great Victoria. But every formed and orderly society has a natural dislike to he swallowed up-in short, to suffer death; and this feeling will probably linger in such strength as indefinitely to delay the final stroke that is to end existence. Canadians have assured me that under this natural sentiment they are never to merge into the adjacent States, and that Canada's loyalty to-day, which must have been otherwise a marvel of filial forgetfulness mnder the negligence and stupidity of the earlier Colonial Office administration, is mainly due to that happy cause. Any way of it, the subject of Tasmania's union with Victoria was one gravely, and by no means disapprovingly, discussed by many Tasmanians I met with, from Mr. Premier Fysh downwards. 


\section{SECTION IV.}

ITOBART TO MELBOURNE, VIÂ LAUNCESTON, BASS'S STRAIT, PORT PHILLIP, AND WILLIAMSTOWN.

Tre approaching Melbourne Exhibition created an extraordinary stir. Tasmania's Governor and lady, Premier and lary, Treasurer, Attorney-Gencral, and a good deal of smaller society were on the wing, and something like all the rest of the Government were to follow in a few days. The other sister Colonies were in the same mood. Victoria had made an unsparing effort, and the rest of the group were competing pleasantly with each other to make that effort effective. Wednestay, the 1st of August, was the opening day, and there was to be a special train of the Tasmanian Main Line on Sunday, in order that we might not fail to catch Monday's Lannceston boat, which was to land us at Mellourne (m) 'Tuesday morning, "the day before the feast."

\section{The Tasmanian Main Line.}

The Tasmanian Main Line, although uncler an acemunlation of unfavourable or unfortunate repute, tuxk us across in fair and comfortable style. It has har much dispute with the Colonial Government, even frem its first moment of life, for it hegan its differences by tming the proposed line away from the 
existing towns, for the sake of an easier and cheaper construction. Long ere the line was finished, its makers were floundering about from insufticient capital, and from want of the adequate credit that might have eased off that trouble. Of course, in these circumstances, the line cost a deal more than if it had heen made by stronger hands, or by the Government itself, as would have been better for both railway and Colony. Then followed the collapse of the contractors, owing to this and other enterprises having mostly gone to the left. The actual line that emerged from all this tangle was not, of course, the best, although perhaps "as good as could he expected." There were rumours that "job lots" of rails, not good enough for elsewhere, were goou enough for poor little Tasmania's Main Line.

The Government felt as though pitchforlied fiom the horns of one dilemma on to those of another in the mixed issue of this concern, at once dead and alive, weak and yet contentiously rigorous, aud, with alternate pleading and threatening, keeping up an everlasting buzz about their ears. The Government's connection with the line was its guarantee of 5 per cent. interest upon a maximum of $£ 650,000$, an amount which was estimated to be sufficient to make the line. But it turned out no such thing in the hands that made it, and thereupon this fundamental item of 232,500 of yearly interest became as a regimental flag, which the hungry enemy, nerved by want, struggled to capture from the committed Gorermment. The line fell sadly short as to its 
engagements, often in speed, still oftener in repair. Even if the Gorernment could, or ought to, indulge a generous or benerolent bias, they were almays confronted by tro sides to that question; for the second-rate quality of the concern (to speak tenderly) might some day summarily send a score of human beingss out of existence, and leave all but wilful murder upon the gorernmental conscience. Mr. Fysh tells me "they are still at him"; but that the case now before the Courts will probably, to his and his colleagues' great satisfaction, enable him to settle fairly and reasonably with the Company, which, he does not at all deny, has now for a long while done, albeit at times in a limping way, much good and convenient service to the Colony.

Well, the Main Line, bad, good, or indifferent, brought us all safely and pleasantly to Launceston. Darkness had set in, and we could only wend our not too weary way to the confortable "Commercial Hotel," where we gathered around that most attractive of all travel-endings, at lcast after seren p.m., the tea-table, complemeuted by what is included in the hunger-edged phrase "a severe tea." IVe had seen somewhat of the fair island's good scenery, from that of the Upper Derwent at the railway crossing, to some of its now snow-clad heights, of which Ben Lomond, towards the north-easterly district, takes precelence, having an elevation of orer 5000 feet, or about 1500 feet above its better known northern prototype. We could not, for the darkness, sce any of the pretty Esk River, which in its double fork fills into the long semi-rea inlet 
of forty miles' length which forms the Tamar, and at whose head, in the completion of the IIome appellative tendency, stands Launceston, a town which has already, as in the Ben Lomond case, surpassed the original of the name in the old world.

\section{Launceston, second Port of Tasmania.}

The daylight showed Launceston to be no unpretentions place in other respects. With about 15,000 people, the flat central town, of lroad and fairly gooil streets, is prettily set off by a hill surrounding; detted orer with many good houses and pretty cottages, along with the ubiquitous orchard and garden. Lannceston harlly grows grapes, although the early kinds, as in the south of England, do ripen, as we might infer from what we casually saw; but for English fruits of every lind it is the very elysium of the Empire, and the jams of Ilobart and Launceston are destined, I doubt not, to visit every accessible part of the earth.

A small river-tug was to conrey us, for the first dozen miles, to the larger steamer, whose 200 tons dimensions precluded her, at that time of the tide, from ascending to Launceston. We were packed rather tightly in the tug, for a troop of twenty-five youths of Geelong accompanied us, on their return from a football match with the Tasmanians. I heard afterwards that the Geelongese had been worsted, which accorded with the experiences of a young footballing friend of mine, belonging to and a native of Queensland. whose impression was that in this game, 
primarily one of muscular strength, climate had mainly to do; so that, white, in the general way, Tasmania would beat Tictoria, the latter would beat New South Wales, and New South Wales Queensland. New Zealand, he thought, would match England; and the colony's Southern Island, unmixed, might eren beat the Mother. But the Geelong boys were merry as crickets. Better luck, perhaps, next time. They gave us song after song; much of it all in patriotic praise of Geelong, and I was proud of my quiet little old fricnd of that well-romembered name, in turning out such a galaxy of gallant youngsters. As Addison says, in lis classic play, "Tis not in mortals to command success, but we'll do more, Sempronius : we'll deserve it."

\section{Bass's Strait: Bad Weather.}

The Strait, in our comparatively little nine humdred tomner, proved the very worst part of our whole outward passage. In spite of my previous seasoning, I was soon as sea-sick as the rawest on board. But this was only in the small close cabin, where I had to retreat for some hours, in order to put a last hand to some "Personal Recollections of Early Melboume and Victoria," with which I had occupied myself pleasantly during all the preceding royage. I was soon nearly "all right" ou reaching" the deck, and nearly again as good as that on lying lown below, in order to impratiently scamp the night that yet separated us from the expected wonders of progress on the northern shore. 


\section{Port Phillip.}

The morning dawned wet, and, still worse, misty. The violent wave jerks of the stormy Straits had long ceased, and we sleepers had revelled in ealmness, awaiting daylight. When I emerged upon the wet deck I reckoned that we were in the Bay's greatest expanse just north of Indented Ifead. I could just see Mount Eliza's tamest of outline, although dear as thiat of an old friend, away eastwards. Northwards appeared a still dimmer mist, which we felt to strain our belief when assured that it stoor for a great fleet of shipping filling Holsonis Bay, from the Williamstown quays and wharfs, accoss to those of old sanclridge, latterly dignified, not without claim, as Port Melbourne:

\section{The Yarra Entrance: "The New Cut."}

Now in quick succession the masts and lunlls clear their outline, for the weather, as we came nearer, began to lighten. Thon Station Peak of the Analies, another rery old friend, loomed ont to the north-west, while the line of Momut Eliza with Iount Martha and Arthur Eeat was completed to the south-east. A few more recognition glances, and we were in the milst of Melbourne's commercial life. Tast changes opened out hefore me. The Williamstown site, with only a village upon it in my time, wiss now covered with streets, and with a surrounding suburb of its own, extending in cottages and gardens far up the western or right bank of the old Yarra. 
Both this and the opposite side were now to me wholly unrecognisable. No doubt it was progress, and all that sort of good thing; but it was as if an old friend had been polished into quite another being, who showed no sort of tie or sympathy with you. The pretty, natural southern Yarra bank, with its clumps of varied indigenous flora - Ti-tree here, heath bushes there, Mesembryanthemum and tufty grasses all about-had been all swept away, and instead had arisen a vast array of mud cutting and of timber pilage, in comnection with Melbourne's grand harbour scheme.

We were presently sailing in great dignity through one completed work of the scheme, namely the "new cut" which disposes of the old "Humbug Reach," to whose time-wasting round-abont we were all confined up to my day. And really, when I glanced down the old, deserted, slovenly-looking Yarra of the Humbug section, I felt disposed, like Mrs. M'Clarty's last supporter in the old Glen Burnie ways, who deserted her chief when honest John Brown's "sappie midden" had been made a flower garden, to permit the impression that the new way was "a hantle sweeter," and tidier too, than the old.

\section{Melbourne Wharf, and Old Friends.}

Melbourne Wharf, a long, almost indefinite stretch, that saluted us at once on emerging from "the eut," wats crowded with a second fleet over and above that which we hat encountered at ILobson's Baty. But. 
it was an orderly array which we traverser, and we soon found our own berth, all in waiting for us in the long chain of ships' bedding.

Eight o'clock rang out as I leaped ashore. I feared that this was unconscionably early for friends, especially as most of those we thought of lived some distance off in the suburbs. None the less two of the principal ones were waiting, namely Mr. Cowderoy, the old and able Secretary of the Melbourne Chamber of Commerce, and Mr. Alfred George Ross, the son of my very old friend and lunsiness partner, Alfred Ross. Another friend, Mr. L. C. Mackinmon, of The trones newspaper, had taken rooms for us at Scott's Hotel, most conveniently placed at the head of the Mestern Market Square. We were congratulated on being able to get hotel accommodation anywhere. When our friend Mackinnon applied months before on our behalf at Menzies', the more quiet and usual resort of families, the waiters, he said, literally laughed in his face at the bare idea of a vacancy. Scott's is a great commercial and squatting place, so that ladies must betake themselves to the first floor instead of the ground. But, in spite of the life and noise leelow, we were so comfortable and well served above, that we not only remained throughout where we were, but arranged to return to the same good quarter's during our second and final stay at Melbourne.

Well, repeating the Hobart procedure, we were to breakfast leisurely and comfortably on board, and then, hetween nine and ten, take our cab) to Scott's. But, in the mean time, I took a scamper up to serott's 
to see the rooms, to take just one glance down Collins Street, and, above all, to secure that morning's newspapers, which latter involve a subject I shall have something to say upon in connection with the marvels of Australasian development. 


\section{$(41)$}

\section{SECTION $\nabla$.}

MELBOURSe, tUE C.APITAL OF VICTORIA, ty 1888.

Business opened at once. The leisurely hours of IIobart and Tasmania were at an end. There was a public engagement that very evening, with the President of the Chamber of Commerce, Irr. Robert Reid. I had made Mr. Reid's acquaintance in London two years before, where, as Vice-President, he had attended as one of the large Colonial delegations to the great and successful Colonial Exhilition, and he had now invited a large bouly of the merchauts of the Chamber and their visitors from all surroundings to meet me at a public dinner. This had been arranged before by telegraph between Melbourne and Holart, so that I was not unprepared. I had had the happy honour to be the first President of the Chamber on its first formation thirty-seren years before, and my numerous children of to-day were to meet their olit father, after that long interval from lis inaugurative presidency.

1Lr. Francis Henty: the Henty Fimily, Funnders of Victoria.

This first day I could not do much in actual personal observation, and the next day must be entirely absorbed by the great Exhibition, in the grand procession of which, to gass thromgh the Arenue of Nations, I was to he homoured with a 
place, while, ly way of further compliment, my place was to be alongside of Mrr. Francis Ienty, who for himself, and also as surviving his elder brother Edward, represented the founding of Tictoria. While just on the verge of the opening of this Exhibition, and the crowning effort and trimmph which it gave to the great Colony founded by this Henty family, it may not lie unsuitalile to say a few words on that subject.

The father, Mr. Thomas Henty, of Sussex, England, who had the large fimily of eight sons and one daughter, took the resolution, just sixty years ago, to emigrate to Australia. The Swan River was making some noise at that time, and Mr. Henty, securing a large grant of land there, sent out a first detachment of two of lis sons to report. Arrived, these adventurous young lads reported unfarourably, and advising to change the destination to Launceston, a small and but little known town in northern Tan Diemen's Land (now Tasmania), they set off thither themselves, re embarking their implements and other colonising material. Their father and the rest of the family followed, with the exception of one brother, who preferred to stay at home.

Although Launceston was preferred to the Swan, there was disappointment in other directions. $\Lambda$ grant of land was no longer attainal,le. The grant system had ended just a fortnight lefore their arrival. They could not even effect an exchange for their abortive grant at the Swan. To pray rent for the firms or grants of others, in that small and as yet almost tradeless community, was not encouraging, and their eyes turned elsewhere. 
Whalers and others had from time to time reported of a great territory on the northern side of the Strait. Reports indeed were of all kints, favourable and otherwise, but they were all of the most meagre and unrelialble character. In short, the whole region was virtually a terre incumpite, with a preponderating bad name from Collins having al handoned it with his proposed colonising convict party in 1803-4.

The Hentys turned their eyes northwards, and took up this forlorn hope once more. Arrived in Launceston in 1831, the following year saw them at work. The dash of the family culminated in Edwart, the second son, then only twenty-two years of age. Patching up an old whale-boat, he sailed across in a north - westerly direction, aroiding the Collins'condemned Port Phillip, , and going west of Cape Otway. IIe was particularly struck by Portland Bay and the green and pastoral look of its surroundings, but he went onwards, passing the Murray River mouth, Kangairoo Island, and sailing up St. Vincent Gulf, beyond the site where Adelaide so soon after arose. He landed at Portland on his return, confirming his good opinion of the place. The next year he started once more, taking this time his fither, who, unable to get any exchange value for his Swan River grant, and unwilling to throw it up for nothing, hat resolved to see it with his own eyes

* Cullins wrote to Lurd Hubart, "When all the disulvantages attending this Bay (Port l'hillip) are puldicly lin.wn, it cammot be supposen that commereial penple will le desirns of visiting Port Phillip." See Illus. Sydney Neus, 30 Aug. 1888. 
before doing so. He did see it, but only to find that it was " sand not land," so it was finally abandoned.

Portland was now the family hope, and Edward Henty got ready to realise it. He engaged a small vessel in October 1834, and storing it with live stock, implements, and other necessaries, he sailed, and after almost incredible ill-luck in adverse winds and storms for thirty-four days, in which a great proportion of his loading was lost, he landed at Portland on the 19th November of that year. His youngest brother Francis, now the sole survivor, and then a lad of eighteen, followed in the ressel's second trip, arriving in December; and the two brothers, the Romulus and Remus of their new Rome, fell at once regularly to work in the colonisation of the comntry.

\section{Followed by Colonising of Port Phillip) by Batmun and Fawkner.}

This morement of the Ilenty family soon commmincated itself elsewhere throughout little V:m Diemen's Land Island, where already the Colonists wre feeling themselves cooped up for want of room, over at least the comparatively small area of country then deemed worth taking up. And thus a syndicate, to use a modern word, was formed at Iobuart, which in the next year, 1835, sent John Batman to Port Phillip; while Fawkner, at Launceston, from whom the Hentys had bought part of dheir outfit of plants and seeds, collected another party, which he sent across the Straits three montlis after Batman. Fawkner followed them limself two months later, nanely in Octolier 1835, and, ly his 
vigorons practical procedure, opened in its centrul part that colonisation of the future Victoria which the Hentys had hegun the previons ycar at the western doorway. Patman landed in May at Indented Hearl, where he made a temporary settlement, and shortly afterwards traversed the country of the present Mellourne and its northern suburbs, making, on 6 th June, a treaty with a number of the natives, at a place on the Merri Creek opposite to Ruckerr" is Hill, only about two miles from Melbourne. But the founding of Mellourne arose out of Fawkner's action; for his party, in obedience to order's to settle only where there was alumlant fresh water, having found this requisite above "the Fills," siuatted down there in consequence; and there, accorlingly, whether for better or worse, arose the modern capital of Victoria, and the worthy rival of its senior Sydney, for the metropolitancy of the Australasian section of our Empire. A fitter choice, it is freely sail, might possibly have been made, as for instance at Geelong. But, such as it is, Fawkner is to be regarded as the founder and fither of Melbourne.

\section{The Messps. Ilentys' work still C'nrecougnised by the Imperial Government.}

Mr. Elward Henty died in 187s, unrecognised in any way for so surpassing a service to Australasia and the Empire, unless we except that usually blind goddess Dame Fortune, who considerately gave him a fair share of the prosperity which he haid inaugurated for so many others. Irs. Henty. however, 
still lives. She, young and beautiful as she was in those days of the child Victoria, threw her early life into the cause of her husband and the Colony, occupying with him the pastoral solitudes of tine grassy valleys of the river Wannon, where, more than forty-four years ago, it was my privilege to meet her, and seek, in the solitary homestead, the hospitalities of the bush. She, and her now venerable surviving brother-in-law, represent to-day the founding of Victoria. When Mrr. Francis Henty honoured me with a farewell banquet of old distingrished Victorian Colonists, I was unable to omit the opportunity of alluding to the striking position of these illustrious survivors; and to the hope that a recognition, which cannot possibly fail to come some time, may not lose half its acceptability and efficiency by coming too late for those most directly interested.

\section{Melbourne, 1840-57, 1857-88.}

Melbourne had grown, since I left it in 1857 , from a population of 80,000 to that of 400,000 . But I could go back for still seventeen years before 1857 , when Melbourne-the officially recognised and laidout Melbourne, that is to say, by which was endorsed the Melbourne of Fawkner-was only three jears old, and was but a scattered rillage of three to four thonsand colonists. I now wandered, on my first day, through countless streets without encountering a single recognisalle olject. A more critical subsequent survey did indeed bring up a scattered few of such oljects, as, for instance. the oll trifuse office in 
Collins Street Eist, the little old Patent Oflice in Lonsdale Street West, and here and there some rather dilapidated or odd-lonking old dwellings in parts of streets outside of any consideralile tide of to-day's business life. But, generally speaking, the old Melbourne of my time, of a full generation past, had been entirely swept away, and, but for the merciful act of still learing the old street names, I might have been dropped into this modern Bahel without any possibility, within at least its own wide boundary, of knowing where in the wile earth I hat arrivel. Even Batman's and the Flagsstaff Hills, which might have somewhat aided a recognition, failed me also and entirely, the first laving been totally swept away by inexorable railway progress at the west end, while its adjacent brother was put out of all recognition by a capping of plantations and pathways-practically one more case of being improved out of existence.

\section{The Tramuays System.}

The first and most striking object of these crowded and busy streets was the tramway system. You could hardly fail to notice it, first of all, because its peculiar noise was incessantly in your ears, and again because you were sellom one clear minute together without the need to look out for a tram, whether to jump upon it for your three hundred or three thousand yards of outing, or to get out of its way. Looking in wonder, as a "new chum," at the mysterionsly self-moving velicle, with all its marvellous 
adaptabilitios, nne was reminded of "IIadji-Balua of Ispahan," who was equally staggered by a like marvel in a different direction, when, as Morier's gcod story groes, he reported, to his master the Persian Shah, alout the mysterious gas lamps, to the effect that London was lighted by magicians with torches. To my ears the ceaseless din of these trams was not at all unpleasant, although I was within a few yards of it at Scott's. The well-distinguished roice of the tram gave me a cheery salutation in the carly morn, to intimate that the lively hurly-burly of another day, with all its hopes as well as work and cares, had opened upon great Melbourne.

This tram system, introluced only about four years before, might be held up as the very climax of the perfection of its lind, only that such statements or predictions are so constantly disproved under the marrels of our usually free competitive progress. It was transported here from Dunedin, and $\mathbf{M r}$. Duncan, who took it to Mellourne, and still retains charge there, brought it to Dunedin from San Francisco-one more of many stepss of advance upon us due to our American cousinhood. Tariously situated steam power factories, including a principal one near the Exhibition, and another, with a conspicuously tall chimney on the South Yarra side, are the energy-producers of the tram system. The many cables, lying just below the street surface, are all set groing at once, and at the same fairly good specel. The cars are conveniently sluwed for stopfing, and, where the cathles cross each other, one of the two car trains, ly agrecment or rule, "stoops 
to conquer" by dropping the cable at the crossing instant, to pick it up again the next moment. The passengers jump on and off with a facility, dispateh, and safety quite unimprovable.

\section{Some Peculiarities in Colonial Progress.}

The fare on most lines is $3 r$. for any distance small or great. In these days of penny posts and penny busses, to maintain an uniform $3 c l$. in such a crowd $l$ business and democratic community as that of Melloume, struck me as symptomatic. It is surely the symptom of a rarely greneral well-doing, as oflierwise it would be intolerable. The same may The said of another feature of a like bearing, namely, that the Melbourne city postage rate is-not a pemny, like, as I think, every other town of the Empire, but two pence-surely an intolerable rate to-day everywhere else.

But I came across another peculiarity, quite as striking, but in an entirely different direction, and including, as I learnt, a much wider area than M[elboume. Having early occasion to send off a considerable number of newsplaper's to expectint friends at Home, I hat them all bought and folded, and had only to sally forth to Gordon \& Gotch's, almost next door, for the wrappers. "But I want gummed wrappers," said I, "not these mere slips of paper, which any one can cut for himself with a paperknife." The shop-boy looked at me a moment with an imperturbable face, and then turned off to his work, as if I were one who spoke some unknown 
jargon which he had no time to listen to. "Haven't you them gummel?" I rejoined, with the sharp tone of despair that does command attention. He shook his head, and went on comnting papers and postage-stamps, and serring a tide of customers. I wraited for a break, and then assumed so resolute an aspect, that the hoy actually waited to hear me. "Where can I get gummed wrappers?" I said. "No where." "Not over all Melbourne?" "No; donit know them; gum your own." I fled back, set all the wrappers required in succession, and gummed them all. But when visitors came in before we were finished, and the grum had dried, and the gumrot hacl hecn talien away for others, we found that this ordinary gum was "no good." It tasted abominally if you licked it for re-rretting, it had quite insufficient colnesion, as some of the prapers were already mloosing. In short, it was not at all the "professional" gum used at Home. So we gare up grmmed wrappers in despair, and took to a ball of twine, in the way that papers used to be dealt with at Home frior to the last generation. Afterwards, lowever, my wife heard that the Post Office issued wappers with halfpenny postage stamps imprinted, and she went off straight for a hundred of them, nerer doubting that the grum would be there as well as the stamp. But the grum was nowhere, and she had a broad hint also that the grmm had not yet appeared upon wraphers in any part of the Australian group. I am proul to seore at least this one step of frogres for the Oli Mother above her go-ahead family. 


\section{The Melbourne Press.}

IIardly, if indeed at all, second to the trams, in the immediately uljective, was the Press. T'o say nothing of an ever-increasing lost of other issues, Melbourne's morning table is simultineously served by three daily papers, the Aryus, the Aye, and the Teleyruph. The list is fairly equal to the average London morning journal; the Argus and Age, in an "all-ro-nd" connparison, are superior. The Aryus is close upon the Times in the paper material and the general get-up, and, as I think, exceeds it in average quantity of contents. The Age is not up to Lryus mark in paper and "get-up," but is l,y far the greater wonder of the two, inasmuch as, while the Aryfus is at 2d. price, the Aye's equal quantity of sixteen to twenty great pages of type are given for a penny. Possibly the Exhibition arerages at the time of my visit were a little above ordinary, but I record what I saw orer several months of time. In point of circulation, of course, the parent is still the man and the colonial offshont the boy; but the pace of the latter is ominous. The 1 lye heads in circulation in Australasia. Alout eighteen months ago the daily output was 68,000 . A few montlis ago it was 76,000 . It may now safely be put at 80,000 ; and this, with comparatively so small a population, is a rapid advance towards the 200,000 to 300,000 of great London press issues. The Aryus is understood to be a little under 50,000 , the respectable old Sydney Morning Herald still a little less, but the Sydney Ecening Nexes as much as 60,000 daily. 
Again, as to position, in point of press machinery, in which there is erer such marvellous advance. One of the Aryus chiefs, just prior to our sailing for Australia in June last, took us to inspect the new Aignes machine, which, combining all the very latest improvements, was destined for the great Melbourne show. But, to graduate us the better to its climax leeight, lie introduced my party to the printing establishment of "the leading journal." Never having seen this before, we were, of course, duly struck as we saw, first the raw paper unrolied at one end of the machine, and then, as quick as countless wheels could take it, printed, folded, and delivered, ready for the lands of the public, at the other. But, when we inspected the new "Argus" machine, we had to learn that the Times, althongh claiming to be at the head of modern journalism, was not, by any means, at such a height in its mechanical manipulation. The Times machine which we looked at put out, I think, about 8000 an hour, and the other machines are from that number to about 10,000 . But this one of the dryus sends through as many copies as 12,000 an hour, and these are not only printed and folded, but also cut, and numerically delivered in separate batches of 25 each.

We had a striking instance of the critical accuracy needed in such machinery. The machine which we were looking at was still on trial, not having yet been delivered as perfect. The pace of the paper sheet, as it was twirled through the machine, secmed the very utmost that paper constitution could stand; so that. if any hitch occurred. through which the suc- 
cessive individual papers, careering onwards at the rate of between three and four per second, trenched, the one's toe upon the other's heel, even to Sim Weller's "double millionth," there was instant confusion and destruction, as we witnessed oftener than once. Subsequently, as I shall have occasion to mention, during our visit to Sydney, we inspected like perfect machinery in the Turn of Country and the Erening Neres office, where we saw the latter paper in the act of being thrown off at the rate of about 12,000 per hour.

\section{Melbourne Trade-A personal Retrospect of Forty Years.}

My young friend Col. Sargood, if I may, in a comparative sense, so patronisingly look down upon his fewer years, invited us, on one occasion, to meet at luncheon some distinguished Exhibition visiturk. As I glanced around on entering the palatial suburban mansion of my friend, and afterwards at the hospitable profusion of the table, hearled by his bright and chanming wife, I went off into a musing retrospect of just forty years ago, when his father opened the small warehouse in Iilinders Street East, which was duly to grow to the headship of Melbourne trade. His father and I lecame very intimate, and, as far as regarded my prort, chicfly for one reason, namely, that whether dealing in hundreals as at first, or in hundreds of thousands ats towards the last, he was always the same. He dient altogether too early for such a man; but, under 
this too common fate, we can now do no more than lament him.

I had resolved to see, inter alia, some of Melbourne's trade; and particularly in two of its greatest lines, which might, in terms as literal as antithetical, be described as, respectively the soft and the hard trade. I intended to begin with the Sargood establishment, to pass thence to the hard or iron wares of McEwen \& Company, Limited, mitigated by association with other metals, rising even to the luxury of silver, and finally to the grim unmitigated iron of $\mathrm{Mr}$. Edward Duckett.

I was, however, intercepted at the outset by the head of another soft goods loouse, my friend $\mathrm{ML}$. Robert Reid, Chairman for this year of the Melbourne Chamber of Commerce; and, while he showed me over the successive floors of what I felt inclined to describe as a vast array of human requirements set out in a most orderly confusion, I was sure that I had not lost much by the accidental exchange of spectacles. Mr. Reid did not need to assure me that, excepting the one department of hoots and shoes, which he did not touch, every item of clothing used or required by cirilised man (both sexes of course) lay before me.

When I concluded at Mr. Duckett's grim region of the unmixed reign of iron, I was interested chiefly in the great and expanding trade in iron wire for purposes of land fencing, and particularly in that novel kind of it known as the barbed fencing. I had seen the facture of that remarkable fencing at the works of my old business friend, Mr. Johnson of 
Manchester, who honoured me with an invitation to stay with hin there during the British Association Meeting of last year. He had purchlaced from an American company the patent rights for Englant. but that did not save him on the Colonial ground. where he was exposed to the world's competition. When lie heard of my intenterl Australian risit. lie asket me to report on wire prospects. Ifere is Mr. Duckett's brief summary, nade with all the nonchalant indifierence of the entire disinterestehess of commeree-" Is to larbenl wire. the American, on the whole, the best hargain. Johnson gront, lunt dear. The Gernan just tonching the Anerican. But withal not much dif'erence in any." But, speaking of wire in general, he noted the mulatudiness of the English packages as connlared with the foreign, piniting in particulan to the tidy bundles of the German make, at comprated with the ligger and unwieldy English, that diffurence alone being suflicient to decide the direction of the trade. This recalled to my mind the two linds of sliovels that nesed to be sent out at the first to our Tichrian and diggers. The one was the old Birmingham shovel, the chief alject of which, we were then inpresenl, must have been to show the strength of back of the English nniner in being alle to lift it. The other was the American lighter article, which was evidently macle to do the greatest amount of work. My friend Mr. Johnson's course seems now clear. In quality he is all right; in price he must come just the turn lower; in the bundling he must tear limself out of the dear old groure. in spite of the tear's 
and sighs over so rude a rupturing of the traditional ways.

But, as the great Exhibition is waiting, I must now in fairness, before adventuring further into Melbourne description, take my readers to the grand spectacle which I had come so far to see. The morning of the 1st of August dawned promisingly, as the sun's reflection on some adjacent roofs assured me. I heard the sounds of countless drums and other instruments for hours of what I considered to be the early morn, with due admiration for such activity, when, bethinking me to consult my watch, I found, to my amazement and alarm, that it was at 9.30 of the forenoon. I had been ordered by my martial friend Col. Sargood and the Committee to be in my place in the edifice by eleven o'clock. I had not noticed that a small make-shift bedroom which we occupied had such limited light approaches as to give hardly better than trrilight. Te made a rapid toilet and breakfast, and after all were in ample time. 


\section{$(57)$}

\section{SECTION TI.}

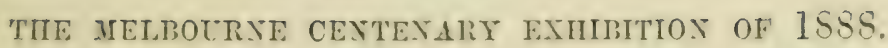

I acst licep to my promisc of not inflicting statistics. The accounts given by the Press are so frightfully elaborate, as to prevent ordinary capacities from eren attempting to read them. Of course, in that case, the specialist ravels in the paradise of his own larticular wants; but where is that first of cares, the gencral realer? Muaning to write for him, I shall not follow these too claborately barl examples. Mellonme am anhition was to give the greatest spectacle of the kind that had ever been seen in either hemisphere; and she has realised her grand aim, for the Exhibition structure which she has reared covers more ground than any other before it. 'I'here has thus been ample room to do full justice to all exhibitors. In passing through some parts of these great areas, on a subsequent occasion, when arrangements were nearer completion than at the opening, I was conscious of the rast advantage of this amplitude of space, as well in setting forth the huge rariety of exhibits, as in diminishing the fatigue of mind, and the dissatisfaction consequent upon too closely compacted objects.

As we waited the hour of noon, which was to start the procession inside the building, after it harl traversed the streets outside, I fell in with not a few 
of my old culonist friends. I first espied Sir Thomas McIlwraith, the Queensland premier, a doughty brother Scot, who with his lady had come above a thousand miles by rail from the far north for the muster, and who was in the same hotel with us. I had to be re-introduced to Mr. Francis Henty, as a very long past acquaintance of the rery slightest kind, formed in the bush nearly fifty years before, was otherwise insulficient. The Worhipful Mayor of Melbourne, Alderman Benjamin, next appeared on the stage, in an extra-magnificent over-dress, with a large and lively following, including his able town clerk, Mr. Fitzgibbon, who has occupied his important post for more than an entire generation. Mr. John Barker, Clerk of Parliament, Mr. Damyon, a brother merchant, Mr. Shadforth, and others came up in fast succession, admitted under privilege into the body of the building. Lastly I fell into the agreeable company of $\mathbf{M r}$. Pinschof, the AustroIIungarian Consul, whose acquaintance I had happily made at my (Chamber of Commerce dimner the evening before, and who politely showed me over the strikingly fine German Court, which was one of the very few that were then in full readiness.

\section{Foreign visitors.}

Mr. Pinschof, who spoke Linglish with rare accuracy for a foreigner, introduced me to some of his German confrères, and in other ways we had quite interesting discussions. I gave him my inpression that the large and varied forejgn element, assembled for the Tixhibition, would do more justice 
to Mellomme's position and prospects in the world, than was done by her own parent country. The memories of the latter were mingled with the babyhood of the place, which seemed as only but yesterday, and rather hindered the full realisation of what Melbourne now was. The Mlother would hegin to do so all the more now when she found her child presenting so oljective a form to other nations. The case wals as though a parrent, who haring hatd his family of sons muler his own eye, where they had grown up with companatively little notice, wats at last, and somewhat of a sulden, alplyisent of their real importance ly noticing the "kow-towing" which visitors adtresed to them equally as to himself.

\section{The opening Procession.}

Dulays haring, as untual, occurred outside, with the first and chief section of the procession, headed by the Governor" and the "Lords and Ladies" it wais not till half-past noon that the grand processional music broke in upon our ears. Then we got ourselves ready. The grent entrance doors gave way ; the vice-regal party headed the troop; we all filerl into our places, and the grand total marched through the Arenue of Nations, and into the great main edifice at its termination, with an accuracy of order and a magnificence of effect that left nuthing to be desired. The rast spaces were packed in erery direction, and there was, besides, a liuge crowd outside, whose hum of satisfaction varied the melodies within. When the grand organ of the occasion, a recent ambitions and costly importation of the ('ity 
municipality, on which as I heard, the customs duty alone was $£ 900$, thundered forth the National Anthem through the vast space, with the loyal response from ten thousand around, the only thing that seemed wanting was the presence of the Royal Lady herself, who was then in all their minds, and who might possibly not have been quite prepared for either the scale or the style which one of the very youngest of her Colonies was already displaying, towards the very farthest ledge of her great Empire.

\section{The Cosmos of Exhibits.}

With many other objects to attend to, I was able only on one other occision to visit the Exhibition. But that was more than two months later, when nearly everything was complete, and the whole presented a spectacle of an altogether unprecedented wealth of variety of the products, not only of Australasia, but, as I believe I am warranted to say, of the whole world. We had but one evening to spare, and we did our best to see the most and the choicest. Our Australasian Colonies had, of course, the fullest representation. The great staples were unrolled in each case. There was a general similitude of product, much as might be looked for from a general scenic and climatic resemblance, extending from the farthest south of Tasmania, up to and even considerably within the southern tropic, where Queenslind still supplements the vast wool-shipments that meet those from more sonthern sections in the London market. New Zealand is rapidly 
asserting her coming supremacy in agricultural products, and in the newer trade of the frozen carcases of her comntless flocks and herds. New South Wales leads in coal, with, however, not a few lively competitors still in infancy, the most preterntious of whom is probably New Zealand, which at Westport, on the western coast of her Southern Istand, can show alrealy a fifty-feet seam of the best quality.

Wine is already an Australian production of consideration. New South Wales, Tictoria, South Australia are all largely and regularly at work upon it, and the St. Huhert brand of Victoria is already accredited with having dismissed the "earthy" flarour, and given to the Colonial article the rarely difticult attaimment of the "clean" taste of a European wine.

Then, what is to be said as to the mineral wealth? Gold and silver, tin and copper, turn up in erery colony in almost ubiquitous presentation. As many of the colonists say, the surface has as yet becn only scratched. Each Colony proully displayed the gold it hal given to the world's commerce, headed by Tictoria with upwards of 200 millions, or, from that small area alone, more than one-fourth of our National Debt. Mount Morgan, the newest of the Queensland wonders, exlibited its strange aurifurous matrix, which is to open a new chapter in the "gold constants," and perhaps, of itself, within a rery few years, to revolutionise, eren beyond united Califormia and Australia of past years, the relations between the two precious metals. silver too was 
in foree, for the Broken Hill interests, of quite recent discovery, have an exceptional character, not dissimilar to that of Mount Morgan, in their novelty of mineral aspect, and their promise of astounding quantity. Excepting only, perhaps, the South Imerican influx of three centuries past, this mine threatens an unprecedented silver product.

The Englinh Courts were richly and rariously endowed, as were the German and other European sections. We samtered into the Art Gallery, but, meeting first the German, were unable to get past its many attractions. But I had already seen at home some of the chefsed'aure in other directions, including Mr. Chevalier's magnificent painting of Mount Cook, which in its snow-clad grandeur, with an eleration of 12,200 fuet, stands monarch of the Australasian group. Lastly, we were specially interested in one object, a very small one in that great galaxy, namely an Aberdeenshire granite fountain, which I had sent out as a present to Victoria, towards the variety of her great show. There were two kangaroos on the top, holding between them a lamp, while the water spouted beneath from the long throats of two emus. The sculptor, with happy thought, did not forget the marsupial ponch with its little occupant, and the inscription in front was "To Victoria, from one of lo'r carliest colonists, in pleasant remembrance, 1840-88." The little present had not been despised, but, on the contrary, assigned a very prominent front position.

The incritalle with John Bull on such grand 
occasions came off in the fullest measure. The lalls, the dinners, the entertainments of every linu, were for a guod fortnight at least, a censuless rontine. I was not able to atteml all of these, and hail surprisingly little time to see and converse with the varied and distinguished comprany assembled for the occasion. Most of the Anstralasian premiers and treasurers were there, and I was much minderl for a raid upon them in the old matter of colonial finance; lut, on the one side or the other, time failed, or dinners and balls were too powerful and peremptory. I had, howerer, the pleasure and advantage of meeting them singly on sulsequent occasions, within their own respective provinces, ant of thoroughtly imbuing them all. as I hope, with my beneficent riews for the funacial well-being of Australasia in regard to reduced rates of interest for their loans. I hail also the pleasure of the hospitalities of $\mathrm{Mr}$. Irayor Benjamin, which were the more enjoral,le, as his late father and his two uncles, who were a firm of prominent merchants of early Melbourne, were, in those now far-off times, my own personal friends. 


\section{SECTION VII.}

\section{MELBOURNE IN 1888-continued.}

Trie intrusion of the great Exhibition has broken my narration of Melbourne's changes; but I must now resume and conclude it. The Exhibition itself is indeed no other than one of the most striking of such changes; for, whereas such things were not even dreamt of in my colonial days, I was now confronted with the grandest spectacle of that kind which had ever been witnessed during that momentons interval since 1851, when Prince Albert so successfully inaugurated this class of most potent stimulus to the progress and commercial brotherhood of nations.

\section{Cullins Street, the cheief Business Thoroughfore.}

Having many other things to tell, I can deal with only a few selected samples of modern Melbourne. Standing on its Western Hill, I looked proudly down Collins Street, as it swept, with just a graceful, and yet not an economically inconvenient, undulation, up again to its eastern termination. The noisy bustle of business life, and the quieter lut equally life-like tide of the rest of out-door society; the quick, energetic movements of the one sex in all its enterprises, and the leisurely grace of the other, in disposing of the satisfactory results of business; together with the ubiquitous trams which, to common 
onvenience, brought both producers and spenters into constant, and, we must hope, into also nutually tolerant contact. were a spectacle in which I never censed to find novelty, wonder, and enjoyment. During the two half-montlis which I was able to give to Mellourue, the one at our first arrival, the wther further into genial spring. I did contrive to see a good many of. although not hy any means all. it: learling objects and features. I wandered thromgh the beautenus plantations of the Fitzroy Gariens. where, forty-eight rear's luefore. on the first nimht of my arrival upon Australian soil, accompanying a friend to his "hut" on the Richmomel flat, the track was lost in darkness and lown-pouring rain, leaving us "dandering" helplessly about till darvn.

I saw with due admiration some of the adjacent and spacious Goremment Olitices, together with the noble Parliament House, now occupied, althomrh still far from finished. There my good and grenial friend, the Hon. Sir James Lorimer, guided me to his omm section, the Upper House. while, afterwards, and within well-hedged steps on his part, he passed me on to those ever-jealous masters, the Lower Honse. The total cost of the great edifice is to be $£ 1,080,500$, of which, at the time of my visit, alout one-third remained unexpended.

Opposite this prominent public building arose the Grand Hotel, its name fairly betrkening its relative dimensions in that indispensable fiell of morlern life. It has, howerer, the peculiarity of heing aliso a Temperance Coffee Palace, and along with wther like prominent and elegant accommodations, in ofter 
parts of the city, it seemed to indicate an inspiring and arenging Nemesis for a previous indifferent repute of these ardent Colonies for the tame enjoyments of sobriety. Down Bourke Street East some little way was a new Opera House, which we visited, to find within a style and way, which, while excelled as to mere dimensions by "Old Drury" and one or two others, was not surpassed - and for myself I thought, with the one leading exception of the Royal Opern, not equalled-in great London.

\section{Rival Places of Interest.}

There was a complimentary pressure upon me for other sights, which time alone interfered with. My excellent friend, the Hon. George Coppin, had his "Old Colonists' Homes," an admirable and useful institution, as I had occasion to know practically in individual cases of its helping hand. The Committee of the old Benevolent Asylum were at my other side. I had an interest, as subscriber and otherwise, in both. When both could not be dealt with, I took the last, at once the nearest in situation and the liggrest in human interests and sympathies. And a truly large, noble, and interesting subject it proved to be.

\section{The Benevolent Asylum.}

The original Asylum of my recollection was a very unpretentious edifice, although relatively imposing in its fine elevated situation outside of hardly more than village Melbourne at the time of its birth. 
But now we entered a granil gateway finm wf the great Victoria Parale, and confronted a luge pile of sucessively added buildings, which left the original, as the rulgar phrase has it, "nowhere." Nearly seven hundred individuals, male and female, the ohl, the destitute, and the dying. were collected in that building, where, without any distinction of mee or creed, they were tended with every care that could mitigate the adversities of old age, bad health, or hat fortune. About two-thirds were males - the sex the most exposed to life's trials and accilents. There was a section of the blind, hetween thirty and forty in number, who were looked after in supplies of raised-print books, and other of their special resources.

The inmates were nearly all passed into old age, excepting in some cases of partial paralysis. Most of these latter were cases of the lower limbs, learing still the head and the fingers in full life and power, although otherwise in helplessly bedridden condition. Two females in this condition, hardly yet leyoud the grace of youth, which set off their pleasant expression, had been brought outside into the bright noonday sun even of the early spring season. Their shapely delicate fingers, actively occupied in a wondrous output of work, perhaps marked a breeding that was not at all uncommon in the miscellaneous gatherings of new settlements, moler the harsh discipline which at times meets the earlier settlers, female as well as male. When they cordially responded to our salutation, we left them under a decided impression that real human happiness and 
comfort hare but little to do with riches and luxury, not to say even other more common or less pretentious resources as to sound life and limb, which we who possess them are too apt to think entirely indispensable to endurable existence.

We were privileged to meet about three hundred of the men at their dimner together in one of their large halls. Not a few of them recollected me, and my business firm, in the old dars forty years and upwarls ago. I made them a short speech, saying that I was delighted to meet so many old friends and fellow-colonists in such plenty and comfort, for their plates were piled up with beef of royal quality, and regetables the Queen herself might enry. I added that, in the struggle we all had had in our youth for life and status, I had come out prosperous, and they mustly, no doubt, the other way, but in most cases, I was sure, without personal blame to themselres. Those who were the successful, I remarked, were to lue envied in those feelings which had established so noble an institution, so capalule of mitigating the inequalities of blind Dame Fortune. I promised them for their library a number of copies of the "Recollections" I was just then passing through the press. To give them all, hotrever, a small money gratuity was a more difficult business, as the medical officer, who dutifully or suspicionsly accompanied us, oljected to every form of it. But we at last hit upon the moljectionathle, and I took my leave greatly the better, socially and otherwise, of the visit. When a Chinese visitor of some authority, shortly before, went over the place, impressed more 
particularly perhaps ly the fact of twelve of his own countrymen being then inmates, and upon terms entirely in common with those for all the others. lie declared, and recorled the declaration in the visitors' book, that the Institution was an lomour to mankind.

\section{The Public Library and other Institutions.}

The Public Library was another characteristic institution which my party were enal,led to orertalie. Dr. Bride, at its head, had justly some pride in showing us over its rarious adornments and utilities. There seemed no stinting in the due furnishing of the commodious edifice. Even an Art Gallery, which is not properly, I think, a principal section of such an institution, had leen, as to quality at least, masparingly endowed. But I was chiefly struck by the numbers of the visitors, their obvionsly practical position in life, and the settled and methodical and thorough way in which they seemed to avail themselves of their public privileges.

Government House and gromuls and the arljacent Botanical Gardens we were able just to glance at in a hurried march through, but we gave rather nure time to a risit to the Zoological Gardens, in the Royal Park, to which the Re-ident, Mr. Le Sontef, son of a very old friend of mine, who used to take great interest in, and in fact foundeul, animal exhibitions of the early time, had most kindly invited us. We had, finally, to be content to have misced not only the Old Colonists' Homes, lut the greatly extended Hospital, and a groud deal clse, including, as 
I latd reluctantly to do, the noble and well-endowed University, and the Melbourne branch of the Royal Mint. We reserve these for our next visit; we must needs leare something for that promised and, we hope, early occasion. It does seem so easy and pleasant nowadays to go to Australia.

\section{The Opening of the New Bridge.}

But there was one sight as to which we were fortunate, and that was the opening of the new bridge. "The bridge" par excellence over the Yarra means, of course, that which is in line with Swanston Street, and which has had a history of editions where I already lose my way. The other "viaduct" over the Yarra, lower down whether as bridge or otherwise, has had its mixed listory too, from the time in 1840 when, after a mile and a half's walk through the bush from "The Beach," we were taken over in a small ferry boat. The first stone bridge, on the great Swanston Street line, was Lennox's, whose opening I remember about 1850 , with a great concourse, including myself, then the member for Melbourne in the colonial Assembly of Sydney, in its honour. It was a grin-looking work, of blue-black basalt, much more solid than beautiful, of which the small land arch on the southern side is still left to help our estimate as to the rest of it. When I, almost complainingly, pointed out to Mr. La Trobe, the then Superintendent or quasi-Governor, that the narrow carriage way, and stilted and even relitively narrower side pathways were ridiculons in line with broad swanston Street les reptient. rather to my disappeintment for 
a man of decided artistic taste as he was, that it was ample for all the wants of the humble place. This was, of course, before the gold; but it confirmed my idea that Mr. La Trobe, who, worthy man as he otherwise was, had a narrow and official sort of mind, could never raise himself to Victorian destinies.

Well, after this Lemmox structure, there was, at least one other, for I have a recollection of reading, when at Home, of a zealous protectionist, who, fully determined that principle and consistency were not to be laughed out of the world if he could help it, had suggested that it should be built of domestic-made brick, instead of the specious pretence of fine stone disloyally imported from adjacent colonies. Mr. Lia 'Trobe might well have been startled out of his narrow propriety if he could have seen the present bridge. The old and apparently inevitable necessity of a bridge - a sort of mountainous central arch, as though to discipline the vulgar by refusing them too many facilities, was in this case eutirely dispensed with, as the bridge was at once straight as an arrow and level as the sea. Even Westminster and Blackfriars at home, with which, as amongst the most recent triumphs of bridge-naking, it canne naturally into comparison, were not free from the old infirmity, only that probably the Thames navigation needs had to be considered in their case The Mayor honoured me with a seat in his carriage for the opening, and at the succeeding luncheon I liat to ackuowledge that my impression was that the Meibume bridge exceeded in width at least, if not 
otherwise. its seniors of $T$ estminster and Blackfriars. When the barrier's were undone, a rast waiting crowd was precipitated upon the new and spacious way, which, however, easily accommodated them ali. Melbourne thus celebrated a grand achierement in urban beanty and utility, which was second, in those respects, only to the rival concurrent attraction of her unsurpassed Exhibition.

\section{The Town Hall and the Town Clerk.}

Mr. Fitzgil,bon, the Town Clerk, conducted me over the grand edifice of the Town Hall. When I remarked upon its ample dinensions and the richness of its furnishings, he coolly remarlied that they had latterly found its quarters rather narrow, and were about to make some additions. The original hall, as I remember, was back from the present, and situated at Collins Lane corner; but that edifice soon fell short of all needs, and a new hall promptly appeared fronting Cullins Street. The wish and the money seem forthcoming simultaneously in such great improvements. But Melbourne, as a London Stock Exchange security, now stands in front of all Australasian Municipalities, and, indeed, of most other colonial or other cities and towns.

\section{The Nayor and the great Town Hall Balls.}

IIis Worship is no way behind his Hall. At one of the balls at which I had the honour to be present, the Mayoress regretted the lad night, which had ln-mitted of only fourteen hundred of company for the two thomsand invited. These wet nights are apt, 
howerer, to be disconcerting. MIy dangliter, in dropping from the calb, plunged one foot inte in puddle. What was to be done, fur she was in no mood to return home again? I remarked, by way of consolation, that, with such danigul comlition, she would attract the sympathy of all eyes for the evening. But, this not yielding much coinfort, I suggested that the company might prefer to look at her undamaged face rather than her injured feet; and so it may have proved, for the latter, by help too of some little dress adroitness, escaped unnoticed.

As I sat ly His Worship and lady at the supper, a strikingly leautiful lady, matronly but still young, sat close to my other side. She had that pronounced prominence of feature of their common Semitic race, which, in youth at least, adds the commanding to the lovalle; and I could not lielp whispering to IIis Worship that here was oue of those Esthers of old, who captured and commanded the in lasuerus of their day. Some one remarked that the lady's figure was not equal to her face, upon which my reflection was that this was merciiully so, for, if the figure had been equal to the divine face, we should all have had to fall down to worship her, involving thereby a breach of the second Commandmenit, to say nothing as to the first.

\section{The Original Mellnurne Cermetery, and sume Old Friends there.}

One visit to old friends I did not, could not, omit; those, namely, who had removed their abode to the narrow final home. At early morn, soon after my 
arrival, I was at the old original cemetery of the west end. There the roiceless dead crowded up before me. They began so early as 1841 , amongst the well-known Langhornes of that time. Passing to 1846 was the beloved young wife of my late friend Joseph Raleigh, a rarely fine woman, cut off thus early, whose strikingly sad funeral I attended. The same year a fine youth of twenty-four, Allan Kenny Renny, of Dundee, beloved by many of us, whose deathbed was watched by his chief intimates, Mr. and Mrs. Cassell, Alfred Ross, nin late partner, James Gill, and myself. We gave him a broken column, fit emblem of a life so prematurely cut short. In 18501 died James Jackson of 'Toorák, Melbourue's chief merchant of his early time, aged only fortyfour. In 1848 was Dr. Edmund Charles Hobson, the friend and scientific correspondent of Sir Richard Owen, and who was ever transmitting to the Prince of Science the much-desired and critical specimens of the marvellous Australian fauna. In 1850 was my old friend, the doughty champion of separation from New South Wales, Mr. Edward Curr, who, after only fifty-two year's of life, quitted the field just the year before his battle was won, who now, proud man though he was when in life, yet, as a good Catholic, besought us from the tomb, "in our charity," to pray for his soul. In 1853 departed my most intimate and pleasant friend, active, zealons, intelligent in all his duties and engagements, "The IIonourable James Horatio Nelson Cilssell, Commissioner of the Customs and Member of the Executive ('ouncil of licturia," whom his widow, since 
then, alas! also passed to the majority, delighted thus in elaborate nomenclature to honour. And lastly, in this very year 1888, came to his rest my most esteemed and very oldest friend. David C. Me.Arthur, father of Victorian banking, the genial "mine host " of the early settlement, whom I had hoped still to see in the flesh, and who, hearing of my intended visit, had latterly told his wife, more than once, that le was waiting for me. He died but a few montlys before I turned up once more in my dear old home.

\section{The Second Cemetery, and yet other Friends.}

And this closes my list in the earlier Campo Santo. But another had been opened later of more adequate dimensions and more convenient situation, which also I subsequently visited, to look down upon other old friends and comrades in life's journey and duties. Two were specially conspicuous to me; namely, Sir John O'Shanassy and Edward Wilson; the former my colleague, aloug with James Stewart Johnston, in the joint representation of Melbourne in Victoria's first legislature; the latter the wellknown chief proprietor of the great Aryus newspaper. Both were men of high mark in their respective ways; O'Shanassy, as being a natureborn statesman, who, while life lasted, stood in the furefront of Tictoria's political life; and Wilson, as a socio-political power, whose business success developed useful ambitions, and who might have worked these to great general good, had not a weak constitution and a too early death terminated lis opportunities. And lastly, anongst old friemels amb 
acquaintances, not yet with the dead, and not yet mentioned, I had the pleasure to meet Sir Wm. Stawell, Sir Francis Murphy, Sir Archibald Michie, Mr. J. S. Johnston, Mr. Mouritz, MIr. T. J. Nankevill, Mr. Jno. Nowlan, Mr. J. A. Marsden, and Dr. Black. But Mr. T. T. A'Beckett, Mr. Germain Nicholson, Mr. David Moore, and some few others I was not fortunate enough to see this time, reserving them, however, of course, for the next.

\section{Suburban Melboume, how changed!}

But, amongst successful efforts at sight-seeing, I must needs see also the Melbourne suburbs, if for no other reason than that I myself lived chiefly in these outside parts during my seventeen Jear's of early colonial life. I lived first at South Yarra, in times when there was only a bush track along what is now the highly fashionalle Toorak Road. Then I went north to the Merri Creek, four to fire miles out of town, where, with a pleasant cottage and ample fruit garden, I spent eight happy years; and finally, on returning from Home in 185.4, happily in the married state, I resided once more on the Sonth Yarra side, where I erected a new idea of an iron house. This is still one of the curiosities of the locality, as Mr. Williamson, Mr.L.A., its present owner, tells me, and it was here that our chlest dimughter was born. I am told that a view of Mellourne and its vast sulmurbs of thousands of scmi-rural strects, and tens of thousands of small and pretty, or substantial and elegant dwellings, with their respective plots of flower and fruit garden, 
taken from some lofty spire of the central parts, gives a panorama which, in pleasant orderly diversity, hats hardly, if at all, any rival.

\section{The Suburban Municipality System.}

Indeed, I soon realised the truth of that accomnt of such change and progress, and to my sorrow in one respect, for all my old haunts, so firr at least as their original or indigenous features were concerned, had been literally improved out of existence. There was aloundance of arlmirable sulstitution, no doult, but the old face had gone, past all return or recognition. And those vast suburlus are a feiture in another respect; they are in themselves a collection of separate cities. At the luncheon on the occasion of the bridge opening, to which I have alluded, seated, as I was, next the Mayor, who again was vext the Chairman of the occasion, the Hon. Arr. Nimmo, Minister of Works, I noticed his Worship hieing, in familiar way, to this, that, and the other, to come up ncarer to the head; and, my curiosity being excited, I asked who they were whom he was thus so plumally signalling. These turned out to be the different mayors of the municipalities around that of old or central Mellourne. Then I asked how many of these sort of sub-empires his Imperial Worship might be able to affiliate. His Worship, rather puzzled over the answer, appealed to Mr. Nimmo, but the answer did not come from either. Nor indeed did I get the interesting fact until I had reached ALr. Fitzgibbon, the Town Clerk, placed a little further off, who, after a special counting for 
the occasion, found that there were eleren municipalities immediately adjacent, and fifteen more beyond these, besides a few odd "shires" all about which also were practically connected municipalities, much as we should view Acton or Ealing or the throng of ultraSouthwarkian torn clusters about great London.

\section{Disappearance of Batman's Hill.}

I have already glanced, in passing, at one dear oll friend who had passed away with so many others, and that was pretty green grassy Batman's Hill, in the far west of the city, with its open mood of "She-oaks," whose wiry green foliage moaned its curious doleful note in the breeze. These now rare trees were with difficulty protected ly Mr. La Trobe from the firewood thieres, erer on the alert for spoil when wood and coal alike had begun to rise in price upon the growing towns. Mr. La Trobe's gorernment office rias for years Batman's squatting cottage or hut on that hill, and I have seen "His Honour" in the carly days more than once sally out to chase off and reprimand the thieves. After this, and much other care of the honoured old hill, he would be as little satisfied as myself to return to life to find the old well-known landmark gone. When I arrived this last time, there was still the stump, so to say, of the hill left, an elevation of about a dozen feet, to which it had been, not raised, but razed; but I noticed at my last look of the sacred spot, just before final departure for IIome, that profane hands were once more at work, evidently to make a clean erasure. 
So I reverently selected some specimens of its rather peculiar geological character, namely, that of a decomposing trap rock, which, at a distance, lonks exactly an ordinary solid trap or blue stone, lut is actually soft or friable like so much clay.

\section{The Great Work of the Melbourne Harbour.}

Amongst Melhourne's most striking changes and improrements, and one which came partially lefore me on first arrival as we sailed up the Yarra, is the truly colossal work of the Mellonurne Ilarthour. Melbourne's site had been originally selected on a requisition, not for harhourage qualities, or indeed for most other needs of a great urban future, but only for immediate fresh-water supply. In other matters generally, it might be said to have been rather hastily or negligently chosen. When the gold came upon us, we were all of necessity suddenly in arms to deliver our port from the unharbour-like qualities which, then at any rate, hecame but too manifest.

My friend, Mr. Alexander Cairns, now, in his old age, retired to Dunedin, a practical man, and arrived shortly before in the Colony, and whom it was refreshing to listen to as he poured out a succession of suggestions for the emergency, was prompt to urge the immediate cutting of the short canal, straight to Hobson's Bay, which, branching from the Yarra just above the bridge, would also carry off those devastating floods which every few years played havoc with Melbourne property. Indeed, the saving in this latter respect might soon of itself 
have repaid the canal. But duly qualified engineers succeeded the practical man, and then, as with duly qualified doctors, there were differences and delay, and during delay, of course, no result whatever. The canal, although at times on the verge of coming into existence, was never made; but a railway to Sandridge took its place, being the first of iron roads opened in Victoria; and, after that partial curing of our harbour defects, attention was devoted to the old Yarra River, which was to be improved, not superseded.

I am not sure if it was not also the same practical genius which suggested an extemporised wharf and dock in Hobson's Bay, made at once out of logs cleeked together, and abundantly at hand out of the infinitude of imports crowded already upon the golden market in its earlier years. It would hare been a crude but interesting experiment, which would have certainly repaid even a very evanescent life; for in the block, with utterly inadequate means to deal simultaneously with hundreds of shipping, the delays and costs of the last few miles, from the Hobson's Bay anchorage to Melbourne, amonnted to even a heavier charge than for all the previous royage. When another like gold rush occurs once more in Australia, Melbourne experiences may not be useless.

Out of all these preliminaries the Melbourne Ifarbour 'Trust arose leisurely into being, and the noise and fame of its great works and still greater ambitions are now everywhere. It has finished the "New Cut," through which we trimmplantly 
passed; it is now extending this uniformly deep cut far out through the Yarra mouth shallows; and it has also in hand a great Dock System, which is to be, or at least may be if required, the greatest in the world. When I asked the chief engineer at what time he expected to finish this costly Melbourne Harbour, his reply was "Never." As Melbourne grows, so will its Harbour, in meeting all its needs.

I had had some pleasant and not unprofitable connection with the Harhour some years liefore, upon the nccasion of its first loan issue being bronght upon the London market. That Conservative old market is seldom canght by new things. This was the Harlonur's first appearance there, and it fared decidedly ill, considering both what it really then was as a security, and what it has since advanced to, in that doubly wary market. Five per cent. interest had to be offered; but, as the comparatively few buyers could not possibly take as much as the whole $£ 250,000$, I charged myself (I would fain say it was in all the accustomed benevolence of husiness, althongh not without profit also) with about one half of the amount. The Harbour Trust now issues 4 per cents.; but, as even these tend already to a premium, my "law," already explained on that point, may soon require a lowrer interest rate, possibly some day even as low as the 3 per cent. which I so strongly recommended lately to its political superior, the Victoria Government.

This old acquaintanceship, of mutual satisfaction, brought me so kind and pressing an invitation to make an inspection of the IIarbour works, that I 
must needs, at any sacrifice of other objects, obey its call, more especially as Mr. Mouritz, its secretary, and its most genial chairman, Alderman O'Grady, were amongst my oldest friends. We had a goodly little company, including, besides the above, the manager and engineer, and Sir James Lorimer, the Government Minister of Defence. Tre ran out into Hobson's Bay, around the still unfinished deep water extremity of the artificial cut, and then we were directed to look at the beginnings of the rast dock excavations, whic! were to be effected by a new kind of "spade," which removed, in no slow succession, ahout half a ton of earth at a turn. The hospitalities of the occasion were relatirely equal to the works, and thus was completed a very pleasant and instructive day.

\section{A Suygestion to Improve Melboume Improvements.}

But might not Melbourne, with all its progress and improrements, be still improred? I thought so as I glanced down Collins and some other chief streets, and marked the awful irregularity of line of either side. Collins Street in particular was thus distinguishable, because the enormons price of the sites had induced some of the later purchasers to bethink themselves of invading the domain of the clouds, if they were to get any adequate return upon the prices they had latterly paid for sites in the reigning "land boom." A dozen floors were already in the air, and, if that sort of thing went nu at present pace, who conld tell when dozens more might surmount these, for, with rapid lift- 
facilities, people might live or work at any height? I wrote to the Mayor, suggesting the introduction of symmetry. But I did not commend the protracted monotony of the Rue de Rivoli; I rather stood for that symmetrical yet varied plan, which, as to the private dwelling-house, was so gracefully illustrated in the Royal Terrace of my native Edinburgh. While each house is complete in itself, there is a relationship in the entire of a raried plan. The business streets, of course, have a different architecture. I offered a prize of $£ 50$ for the best sketch of some such plan.

The Mayor honoured me with a well-considered reply, in which he took objection solely to tying up the freedom of building adaptation and progress, which a once-for-all construction of this kind might involve. That is, of course, a real point; but the counter points seem to me to outweigh it, especially in checking the unseemly extravagances alluded to. Any symmetrical plan adopted would probably be a great step forward at once secured, nor need after progress entirely cut it off from adaptation. I suggested, too, that if the idea were thrown out authoritatirely, certain streets, not already committed, as perhaps Collins Street already is, to too mich of objective individual peculiarity, might take the matter up respectively for themselves, with the result that the new development might form the cynosure of Melbourne street life, and secure in consequence an adrance of 25 or 50 per cent. in value. His Worship has promiserl me that the subject should not escape attention. 
I may yet find that in this, as in much else, young Colonies are easier to dislodge from accustomed old grooves than the seniors at Home. I took very great interest in the question of the reconstruction and improvement of Central I.ondon, so urgently needed in 110 few respects, and some years ago I gave, through the Society of Arts, large prizes for essays on the subject. I hope that I have not seen the last of that effort; but, as Dr. B. W. Richardson, a hand much longer than mine at that bellows, may confirm, old Conservative London is slow to move in new directions. One of the needed improvements was a great roomy and comnected "Subterranean," seeing that now our increasing interests, scientific and sanitary, needed a constant access without the need, on every recurring occasion, of having to break up the narrow and over-packed streets. Melbourne would soon have the same need, and the reconstructions I recommended might help their commencement ere site values, as now in London's very centre, ran too high to be meddled with. Whatever might be done for the central parts of London, whether above or below, the central radius of about five hundred yards around the Bank and Exchange must be dropped out through its overpowering purchase weight in gold. Some discussion having arisen, on the occasion of one of my meetings, as to a clearing-out value of only one of its streets, namely Lombard Street, with its banking and financing throng all claiming disturbance valuation as well as site valuation, this total of value was put, upon some authority said to be reliabie, at one hundred millions! 


\section{The Foung Prince of Schlesuig-Holstein, 18.50.}

Before quitting this large and varied suljject of modern Melbourne and its spacious suburls, let me mention one of my most pleasant reminiscences, which came up to me in meeting at Scott's an old friemd and well-known colonist, Mr. John Nowlan. He was the business partner of the late Cap,t. Stanley Carr, who in 1850, arrived amongst us with lis interesting and amiable roung charge, the late Prince of Schleswig-Holstein, then but nineteen years old, and whose risit was quite an event to our quiet community of those pre-gold times. The distinguished party arrived from IIanburg by one of the Godeffroy's ships, and, as I had heen the originator of the German enigration to Melbourne, begun the year before through help of Delius of IBremen and the Godeffroys, they fell, as it were, into my arms. They stayed for a few days at my modest cottage on the Merri Creek, where grapes, plums, peaches and such like, might, at least as to quantity, have made up for those left behind on the Rhine and the Elbe. The Prince was a universal farourite. He had the haute pulitesse, so attractive especially in the ingenuous modesty of youth, of seeming to consider that every one else was to be preferred to himself. Two sisters helped me with the small establishment in those pre-marriage days; and we gave a ball to the Prince, or, more strictly, to those Merri Creek maidens around, who sighed for a chance of a dance with such a partner. Some of them secured it; but they had all to realise, 
whether to disappointment or otherwise, that the perfect courtesy of the Prince had the additional high virtue of a perfect impartiality. How time flies, and what great events come on in its quick succession! The Prince's younger brother became afterwards our Queen's son-in-law. The Prince limself died early, but he is represented by three danghters, the eldest of whom is to-day Empress of Germany. 


\section{$(87)$}

\section{SECTION VIII.}

MELBOURNE 'TO SYDNEY BY RAIL.

AfrTin a most busy half-month in Melbourne, we broke resolutely away to take, at this cool early spring time, the warmer colonies to the north, New South Wales and Qucensland. As to the latter, at any rate, we expected to arrive at the very choicest season. As to Melbourne at this time, the weather was much too cold to be agreeable, and even Sydney, we heard, was not yet very much milder. The cold winter that had prevailed to the south of the Straits had spread over here also.

\section{Official Courtesies and Free Ruiluay Passes.}

We had decided not to take the through express or mail, which, as it started in the afteruoon, would have taken us through Victoria almost wholly in the dark. We therefore took the day train for Albury, giving us some hours at that New South Wales border town, whence we would go on, per night mail, to Sydney. We, as old colonists, had been most handsomely treated in the matter of railway free passes, first by Mr. Fysh for Tasmania, and next by the Victorian Government, represented by our kind and most attentive friend Mr. Labertouche, secretary for the railways. The latter, indeed, apprised me that there was in waiting for me the gold key entitling me, as a member of 
Victoria's earliest Parliament, to a free railway pass for life. Not only so, but when in Sydney, later on, this pass was pocket-picked from my wife, our friend replaced it by another, although I offered, but in vain, to pay at least the gold material, by way of punishing our negligence. Next, in due time, came a courteous letter from Sir Henry Parkes, the New South Wales Premier, to the effect that he would instruct the Albury station-master to make us comfortable as we passed through. Sir Henry is a very old friend of mine, of as far back as 1850 , in which year he sat with me in the legislature of the then undivided colony at Srdney. But when we met shortly after at Sydney he told me that his knowledge of me had extended to about a year longer than mine of himself; for, being in Melbourne in 1849, he attended an election meeting at which I had made a speech as candidate for Melbourne in the Colonial House, and which speech he had occasion to communicate to the Sydney Press. Later on the passes came also for Queensland from our friend Sir Thomas Mellwraith.

\section{Australian Scenery: Dead and Dying Timber.}

Away we started, therefore, for the north, proposing, after taking the two Colonies there, together with New Zealand, to return to Melbourne in time for a second half-month, during which we hoped to see something of the interior, under improved auspices as to weather with the advance of spring. Our proposed route was not, as regarded Tictorian scenery, hy any means the finest. That would have 
been in the westerly direction, towarls the Grampian Mountains and Portland, a large area of almost ubiquitous beauty, which Sir Thomas Mitchell christened Australia Felix, and which the IIenty family, as already narrated, first opened to colonisition. But our present route, excepting about the first forty miles to Kilmore, was all new to me. Not much of interest, however, apleared to us. The various little country towns and railway stations had a remarkably general similarity of look, and the same might one say of the country, which was in general the open forest, with the grass-clothed ground, which is at once, as I might, in seeming contradiction say, the beanty and the monotony of A ustralian scenery.

The number's of dead trees at times gare a most weird look to large areas, and, when these were diversified by the more or less scorched or charred trunks of the living, one had the saddening impression ąs though gazing upon a vast camp not only of the dead, who were, of course, past all pain equally with all hope, but also of the wounded in all stages of hope or despair. This view of Australian indigenous field and forest struck me so strongly and repeatedly that I hope to be excused if I repeatedly refer to it. My thought was that these poor trees, exposed as they are to bush-fire scorchings every year or two, especially during the almost periodical droughts, have hardly a chance of full and healthy growth. We might liken them to some family whose dwelling had a mischierous habit, every few years, of catching fire. The inmates might 
not be all burnt to death, but those who did escape had their skins so scorched as to seriously impair health and life, to say nothing of beauty, in their after career. Consequently, through almost all the country we now traversed, there was the noticeable absence of grand, strong, healthy monarchs of the forest, and the equally noticeable presence of a plentiful proportion of poor rickety growths, young and old, whose ugly stems and scant struggling foliage betokened the casualties and sufferings of the past. Where the gum trees are not exposed to fires they are large and graceful, with their fair share of foliage. In New Zealand, for instance, the Blue Gum thus flourishes in great beauty, and is a general favourite, although the more regular moisture of the climate is there, of course, a special help.

I found myself revolving at times how this evil of fires, which so terribly reduced the beauty as well as the value of the country, could be remedied. The crowding together of the healthy life, young or old, with the dead and the wounded seems the chief evil. If these latter were cleared away, if all but the best trees, in both economic and scenic sense, were got rid of, how beautiful Australia in general would be, and, as one might infer, how much more available its territory. I thought of an apparatus of powerful steam or electric sawing machines on a scale which a government, dealing with so rast a territory, might le able to apply, sawing down useless or damaged growths at one or two per minute, then blowing up the roots with dynamite, and finally cross-cutting and stacking up for firewood all the clearable refuse. 
One could only, of course, do that to advantage on somewhat level ground, and perhaps only where there was water; but, even so, that would effect a grand clearing and constitute a fair beginning.

\section{The River Murray, and Allury: Colonial Wine.}

Now we are approaching Albury, and must look out for the boundary of either colony, the great River Murray. I rushed alternately to each side of the carriage to catch the expected wide expanse of welcome water, but to my astonishment we were at the Albury station, apparently without crossing. I did indeed notice a not inconsiderable river course, crossed about a mile south of the town, but I imagined it to be some moderate tributary. But this was the Murray none the less. Of course the bridge sought the narrowest river crossing, and when we afterwards sauntered down to it, and took notice of a good strong current, and the indications of some depth, our respect gradually returned.

At the time of our risit a large drove of cattle was crossing into Tictoria, and we were looking for some scene in connection with the Live Stock importation tax, which Victoria, by a curious economic logic, inflicts upon her own prblic in the interests of perhaps the best-off class within her bounds, namely, her squatters. But it turned out that these wer: Victorian cattle, which, under the Scriptural principle of giving good for evil, her northern sister had permitted freely to enter, and, when disappointed of a sale, as freely to quit her boundaries.

Albury is rather a pretentions edition of the 
interior country town. It is laid out in the usual rectangular way, with abundant width of street. The reporter of the Argus met us at the station, having heard from Melbourne of our departure. He took us to a nice tidy hotel about the town's centre, near the Post Office, and then directed our calman to show us the sights, including the Murray. We afterwards called for Mr. Mayor Mate, who was a sort of head general merchant, with the enviable repute of a large proprietary holding of corner and other town allotments. He told me that Albury was to be the seat of gorernment of federated Australasia. The town reminded me somewhat of Melboume when about eight years old. Albury had now 8000 people, and if the Melbourne resemblance lasts it may he a big place ere long. We concluded our day at Mr. Fallon's wine vaults, where we found some wine-blending going on in a most protracted pouring and repouring of each kind into the other, which seemed to me rather dissipative of the strength. We next took to tasting, and had some delicate and fair "Tokay." But I am always against the application of old European names to Australian wines, as all difference of flavour is apt to be set down as inferiority.

\section{New South Wales, and Bracing Cold.}

Towards eleren we returned to the station to find our sleeping places ready. I regretted to pass through so much country in the dark, much of it, on the one side of our train as on the other, of the longsettled Yass pastures for instance, well worth looking 
at. We used to joke an old frient, whose mind still tended to the "despatch of husiness" even in pleasure travel, that he took the Rline by night to save time. We were, althongh involuntarily, also under such time pressure. When I awoke upon a bright early morn, between Yass and Goullum, the comitry was all white with hoar frost, and the carriage window crusted inside with ice. Was not the comntry to be congratulated on this sign of its invigorating climate? Goulburn is one more country town of the size-pretensions of Albury, but older, and, as a magisterial centre, with some display of pullic edifices. There were increasing signs of dronght as we went northwards, as hardly any rain had fallen up there for some sis months past. At last, as we turned eastwards after Parramatta junction, the crowded cottages of all sizes, mostly wooden, with here and there handsome private residences, told that we were apuroaching the great centre Sydney, the senior sister and worthy rival of the other great centre we had just left in Victoria. 


\section{SECTION IX.}

SYDNEY, THF CAPITAL OF NEW SOCTH WALES, IN 1888. WE were quite an hour late in arriving, and so missed a greeting from my worthy old friend, the Hon. George Alfred Lloyd. But he soon appeared at our "Roberts' Hotel," to which we had been recommended, and tre resimmed a very old acquaintance, which had not however been quite an unbroken mutual absence, as between us we have been making these Home or rice rersâ trips, which seem now so easy even to our rather advanced years. I have not many old friends in Sydney, beyond Mr. Lloyd and his venerable friend and political associate the Premier. They have mostly now departed this life. Sir William Nanning, whom I had the great pleasure of seeing alive and well, Mr. Augustus Morris, and the Hon. Alexander Campbell, the latter, like myself and Mr. Lloyd, slightly the worse for years, are pretty nearly my surviving list.

\section{Comparison with Melbourne.}

Whether Sydney or Melbourne was the most changer, all things taken together, since I quitted Anstralia more than a generation since, it might be hard to say. Obrious differences presented themselves in the comparison of the two sister capitals. No one capaible of judging has any doubt, even in 
Sydnoy itself, as I should feel sure, that Melbourne, the junior sister, is decidedly more presentable, as a city, than the senior. And this very seniority of the latter explains most of the difference; for while surveyors, with modern ideas and experiences, had the laying out of Nelbourne, in comparatively speaking our own day, poor old Sydney, brought to lirth years ere this fertile century had even dawned, had not one particle of such systematically nursing care. Its one main town thoroughfare, George Street, sprawled away, slightly zig-zagrging, beginning close to the natural harbour which is now Sydney Core; while to right and left of this main line, like the tiny legs of a centipede, althongh entirely without the creature's symmetry, ran the lanes or cross streets of the lesser order, mostly in a royally free licence as to qualities desirable in either street-way or edifices. The illustrated local Press lately gave some sketches of the venerable mansions of that time, which had survived, presumably in a good deal of discomfort to their occupants, down to the present. The Syduey of to-day has had to patch "1p, or, in desperation, to wade destructively through, almost like a telescoping railway train, this ugly nest, as it were, of old sleeping cars.

Thus a strictly city glance orer Sydney falls sadly short of the same glance directed orer the perfectly systematic field of modern Melbourne. Then, again, the tram systems are almost as distinctly different as the respective general aspects, and in this case also to Sydney's disadrantage. Insteald of the tidy short Melbourne train, of two carriages only, the 
one open, the other, for choice, closed, and passing and repassing erery minute or two of the entire day, we have in Sydney a huge, lumbering, ugly, and, I may add, black and dirty-looking stean-engine tram, which does not at all go so conveniently often, and is not nearly so simple in its boarding and alighting arrangements. One thing I admired lowever, namely the ticket arrangement, which dispenses altogether with the passing of money, a sad necessity if we are successfully to circumvent human nature.

When we pass to the general from these two special aspects, Sydney begins to square up with her sister. In point of the tide of business, coursing through the chief streets, I did not distinguish much difference, George Street being, in that matter, quite a match for Collins or any other Melbourne street. Passing now to the architectural question, and to the grand and elegant piles of the public buildings, and those of the almost countless banks and other institutions, one is apt to get bewildered over a sulject or question, numerically so very large, and individually so competitively varied. But in the end I had to side with Melbourne, owing chiefly to her extraordinary efforts of the last few years, when overflowing treasuries, public and private, have literally becn giving to the city and Colony "money which she does not know what to do with." During these years Sydney improvement has been comparatively "scamped" in the rival race for the sake of further railway connection orer her Colony's vast areas, wlich great areas are thus, for the day 
at least, a comparative disadvantage, and have given of late a public revenue deficit, to compare with Melbourne's joyous surplus.

But the spirit of rivalry is too keen, and the ultimate resources are too assured, to keep the on city long behind the other. Sydney's new Town Hall is more pretentious than eren that of Melbourne. which had so awed my imagination. I had another, and even a better, if also quite an amusing illustration of the rival spirit, and its contempt for the slavery of mere costs. While on a pleasant ramble throngh old ground, under the experienced guidance of my old friend Mr. Lloyd, we passed the skeleton of a rast and most elegant-looking structure which, as har.lly half completel, and yet without its staff of building hands, I supposed to lie suffering only from the indispensable interval of the workmen's dinner hour. Placed too in one of the choicest of public sites, it promised to be such a palace as Queen $T$ ictoria might prefer in the whole city, if she arrived after its final completion. On inquiry, I had to learn that this was a contemplated new hospital, but whose extravagant plan, as it developed into reality, had so scared even Sydney's profusion that further supplies were refuser, after a trifle of some $£ 130,000$ had been expended. The site also, a remarkably choice one, had been considered a needless part of the extraragance.

Next, as to commerce, I was certainly struck with the superior array of that of Melbourne. But this is probably due to the fact of the entire field there being visible at one glance, while that of Sydney struck me as more scattered, and with proportionately less 
effect. This is the more likely explanation, seeing that New South Wales is to-day represented, in its capital Sydney, by more commerce than Victoria is at Melbourne, to the extent of some solid millions yearly. The sudden and enormous gold finds of Victoria had sent Melbourne almost at once ahead of Sydney, so that her commerce, her revenues, and her population were for a number of years at least 50 per cent. the greater of the two. But after Victoria's gold had seriously fallen off, although still several times that of the New South Wales fields, and after too, as I fear I must add, Tictoria had begun to "develope" her restrictive Protection, the senior sister has been steadily retrieving her position; so much so, indeed, as to have already passed her junior over the whole ground, being now, by latest returus, decidedly alsead in commerce, considerably in revenue, ant just past her even in population. Owing perhaps to protective influences, the Melbourne population is still ahead of that of Sydney, in the proportion of about 400,000 to 350,000 . Whether this is with advantage or not may be taken as part of a question, which is altogether inevitahle in this mainly economic view of mine of these Colonies, and a question for which both my readers and myself must presently prepare ourselves.

\section{Sydney's Harbour of Port Jackson.}

But if Sydney, in some leading urban characteristics, has been but at a limping gait alongside of her great and more graceful sister, she has a reserve in 
store, a sort of Napoleonic Old Guard, which can never surrender, and which easily routs every opponent of its kind along a whole line, which she might. even presume to say comprises, not Australia only, but the world; and that is her harbour. One of Cook's sailors, of the name of Jackson, espied from the mast cap, in passing outside, this landlocked harbour, and it was honoured with his name, as though some trivial matter, only good enough for one of the ship's hands. And afterwards, too, the commencing settlement, in entire oblivinusness of Port Jackson, was made at Botany Bay. By fortunate accidents, rather than by any intention, Port Jackson happened to be in close vicinity, and was soon after occupied in preference to the original settlement. And thus arose, under her accelerating conditions, that fair city of our Southern Empire which is already a power even in her comparative infancy, and the acknorledged mistress of the great Pacific which she confronts.

The merely economic view of the harbour is probably nerer to be challenged, and that is, of course, the main consideration for a great commercial city. But I have much doubt whether the scenic effect is not eren already in rapid decline, from what must otherwise be in the nature of a highly satisfactory result, namely the enormous extension of the city. Those charming natural inlets of the earlier and smaller days, with their fringe of beach or seasplashed rocks, crowned by green bushes, or dwarf forest growth, whose hardy verdure defied even an Australian drought, are all passing into the limbo 
of the almost-forgotten past, and are gazed upon by a new generation which knew not the primitive indigenous "Joseph" of earlier date. The base, the side, the top are alike capped by the inexorable progress of many human needs and wants, and, like the Emerald Hill of Melbourne, the emerald blade or its congener's will soon in many parts be the only thing wanting in the crowded scene. When I lookerl orer the grand expanses of the Derwent which grace Sydney's little sister Hobart, I thought that fortune would have better arranged for the interests of both if either the respective harbours or the respective cities had changed places.

As though to supplement or affirm this view, that the city, in proper relative dimensions, has already outgrown its larbour, is the fact that its sewage has already so fouled the once clear pure waters on which it sits as to render imperative a grand and costly exit into the Pacific; unless, indeed, we can at last practically realise that we can deal otherwise than by thus throwing array what may be made the natural restorative to the exhaustion of soils. I can never divest myself of the idea that the costly perplexities of both Sydney and Melbourne in this matter, especially in view of their rather dry and thirsty climates, might have the very opposite results, by a scheme upon an adequate scale for conveying the manure inland for agricultural purposes. With the strong pressure of a great artificial elevation at starting, the sewage material, in a state of thorough dissolution, might le transmitted far and 
wide for fertilising use, to return perhaps some clear revenue instead of causing costly loss.

\section{Comparison of New South Wrales and Victoria.}

New South Wales is much larger in area than Victoria-between three and four times the area in fact. I question if there is, at present at least, any advantage in this mere size, although in the next century, when population and irrigation can do their doub'e work, the result may be different. But at present, when there are only just above a million people to each colony, the compact little Tictoria, with her large proportion of fertile land, may have rather the advantage. It is as though, with fairly equal resources to l,ring up, the one laad the disadrantage to bring them from three times the distance of the other.

But Victoria may rejoice in one decided advantage, and that is her climate. Not only is it cooler on an average by some degrees, but it is much less affected by the great A ustralian economic plague of drought. Victoria is far indeed from being drought-free, and she has at times a prevalence of hot winds that might scare even a tropical Queenslander; but, owing to her largely sea-girt houndaries, she is much less roughily dealt with in respect of dronglit. As we sailed by steamer from Sydney to Brishanc, along north New South Wales anil south Queensland, the smoke of many successive bush fires indicated the suffering country, while we had, just lefore, quitted Victoria, green and beautiful in almost every occupied and cultivated part. 
We pail our respects at Government House to Lord and Lady Carrington, at their afternoon tea reception. The Governor is charmingly frank-so much so indeed, that, not hearing my friend Lloyd give me the name, I supposed I had fallen to the equerry who was waiting a chance of his master having a half-minute to spare, and to whom I addressed some pour pusser le temps observations. But hearing my friend address him as "my lord," I began to suspect some mistake, and asked whom I had the honour to be speaking to. But that made no difference; Lord Carrington was all the same.

Sir Henry Parkes, Premier of New South Wales.

From that I went to Sir Henry Parkes. The Premier is an impressive old man. He has fought many a battle. He bears it in his pale face and very white hair, although still with a commanding look and presence. He is particularly remarkable for speaking quietly and deliberately, as though a few selected words were enough for one idea, the rest being understood. And then, when he had thus dismissed any offered subject, you saw that he was patiently waiting your pleasure for another. We were soon into the thick of colonial finance. I told him my plan, particularly as to the advantage of these Colonies acting co-operatively, so as to present a large uniform stock to the IIome market.

I saw that he had the idea that to take, for instance, such an almost "lame duck" as New Zealand into the union wonld bring down rather than raise the stock of the others. However, I assured 
him that this rould not be so, and that a political federation, which we supposed these Colonies must some day, in all good common sense, accomplish, would have a marvellous effect on the value of their loans, as was shown in the Canadian Dominion case.

This quickly led to the tariff and protection difficulties, and then I became aware that Sir Henry was in no humour either for agreements or for being, politically at least, agreeable. With the external quietness of the experienced statesman, it was yet evident that to his mind there did not appear much present hope of intercolonial federation. It was, in fact, chiefly from Sir Henry's attitude that I took the idea that the only way in which intercolonial federation might be practicable was ly reserving for a time the tariff freedom of each Colony. The suspicions fears and difficulties otherwise were endless. Sir Henry is resolute to keep for his Colony that freedom of exchange to all its workers for the products of their labour which New South Wales has as yet enjoyed. She is now, in fact, the only one of the group which still keeps to this freedom, all the others having more or less adopted restriction, and its reduced labour output, which they confuse their minds with as "protection."

But this is not all, for Tictoria, and perhaps Queensland and others, have indicated for a separate tariff respectively, and for unwillingness to make common commercial cause with the other Colonies. Victoria's live-stock tax against New South Wales was in this respect a glaring and irritating case. The Victorian Parliament has lately signified that 
it wishes to still increase this tax. Thus Victoria might be as much opposed to a federation, which might take a large-minded fancy to abolish this individualism, as New South Wales might be opposed to what was likely to abolish her trading freedom.

Sir Heury spoke rather reproachfully of certain Victorian statesmen, who, with good heads and fundamentally correct economic views, ought to be supporting him in his hard battle, instead of going with their wrong-headed masses. He mentioned particularly Mrr. Service and Mr. Gillies. I soothingly alleged that, if these men threw up the reins, the Colony might go into 50 and 60 per cent. protection instead of 25 and 30 ; and also, by way of a climax of comfort, I added that, if " the worst came to the worst," any heavy additional Victorian protection would send New South Wales still more decidedly allead in commerce. I had also some conversation on the same subjects, but especially the financial section, with the Hon. Mr. Burns, the Treasurer. I afterwards had the high distinction, as well as great pleasure, to meet this gentleman, together with quite a number of sydney's leading citizens, at a dimner in the Union Club, given to me by Mr. S. A. Joseph, the President of the Sydney Chamber of Commerce, whom I had met some weeks before at the dinner griven by the President of the Melbourne Chamber.

I found myself, on this very interesting occusion, in conpany with many intelligent men, the leaders of the Colony's commerce, and of high repute for capacious business minds. The Hon. Henry Mort, M.L.C., is, as I told him, a name tantamount 
to an institution, and with him the IIon. II. C. Dangar, M.L.C., Director of the Anstralian Mortgrage Land and Finance Company, which stands admittedly at the head of its own class of business in these Colonies. My friend and correspondent, Mr. Josiah Mullens, and Mr. R. I. Black are, as stock and share brokers, amongst the leading men of the Sydney Stock Exchange. Mr. Orr, Mianager of the Cnion Bank of Australia, was the son of an old Melboume friend, Mr. John Orr, one of the earliest of the Port Plillip merchants; and last, but not least, was Mr. T. A. Dibbs, the managing head of the great, old, and surpassingly prosperous Commercial Banking Company of Sydney, whom it was my good fortune to sit next during the dinner, and with whom, as a sagacious man of business, I was particularly struck and most favourably impressed. Mr. Dibbs, I may here add, had most hospitably offered to take my party a sail in his yacht, in order to shew us the almost interminable succession of beautiful variety in the inlets and scenery of Port Jackson. But this most tempting trip we were compelled to forego from want of time.

I might have met still more of these Sychey magnates of commerce, as Mr. Joseph informed me, but for the meeting, during the current week, of the Australasian Association for the Promotion of Science, an institution liappily and suecessfully inaugurated at this time, and destined, we cammot doubt, to a future of unusual distinction in a land of such scientific wonders and novelties as Australia. 


\section{SECTION $\mathrm{X}$.}

AN ALTOGE'THER INEVITABLE DIGRESSION UPON FREE TRADE AND PROTECIION IN AUSTRALASIA.

[N.B.-Those who cannot sucallow this dose are asked to "drop it" and pass on.]

Thex I had hurried up to the great Exhibition, as narrated in a preceding section, uncertain whether I might not be too late for my appointed place there, and while wandering over the vast interior, to which my special ticket had admitted me, not certain where in particular to go, I espied, at some distance, a figure which I was sure I recognised, and a figure not readily missed, in its robust outline, even at some distance. This was my friend Sir Thomas McIlwraith, Premier of Queensland, arrived, like so many others, from far and near, at the grand show. His leisurely pace set me at once at rest as to the time question; in fact, as it turned out, we were a good hour too early, so that the Premier and I had time for some chat.

Sir Thomas is a zealous protectionist; and Iwell, I am not of that "persuasion." And so, as with two theologians, over equally absorbing differences, we naturally gravitated to conflict, under the happy sin-covering expectation, perhaps equally fervent on either side, of being the favoured instrument "that converteth one from the error of his ways." I put it to Sir Thomas that every 
economist of any eminence, from Adam Smith downwards, had advocated the economic advantage of freedom in trading; that is to say, freedom of exchange to every worker for the product of his labour, as compared with the restrictive system in that respect, known by the misleading term Protection.

Sir Thomas, who is, in things generally, a hardheaded, common-sense brother Scot, did not deny this fact. Indeed he felt bound to answer it, and here is his answer: "Ah, but we have found out many things since these economists." Well, I shall take this answer, and allow Sir Thomas and his co-believers to expound what they mean by it, as they did indeed after their own fashion, on many opportunities which I had with many of them. One of these, a squatting colonist, Mr. McCrae by name, whom I met at Roberts' Hotel, Sydney, was perhaps most of all useful to me, in a zealous outpour, in his pronounced and supremely selfconvinced way, of the Catechism of Protection. But I had other conversations, at all odd times, with many others, including premiers, ex-premiers, and treasurers by the score, to say nothing of commoner folk. There might be an endless repetition in distinguishing individuals. I shall therefore take the case as a whole, and aim at some logical sequence. With this view I shall bring but two parties upon the stage, namely, an abstract He, who stands for all the protectionist side, and a concrete I, who stands for the readers' humble servant, listening and responding. 


\section{Some Introductory Principles.}

But, before adventuring into battle, I wish to offer just a few introductory principles, which may I think be agreed to on both sides.

Economic Advantage alone dealt with: One Illustration.

Economic advantage is, of course, what we are now solely concerned with. Where other things intervene, the social, the sanitary consideration, \&c., the ground changes. For instance, the late Mr. Syme, of his now ultra-Protectionist Melbourne Age newspaper, used to hold that countries, such as the Western States of America, ought not to permit monotonous ubiquitous wheat-growing, but should, on social considerations, coerce the people into a greater variety of employment, even at economic disadvantage. And, no doubt, provided there were real grounds for the apprehension, he presents a case which is not necessarily at variance with principles of trading freedom, for it is admitted to be an economic loss, incurred for the sake of a social gain.

\section{Another Illustration.}

Or, to vary this illustration, suppose some great self-goveruing Newcastle, so surpasingly rich in coal, that to work solely at that article paid the latbourer better than anything else. All, therefore, took to the coal, and got enormous wages; and these in turn were spent frecly in all kinds of woond things got in exchange from the outside countries, which 
bought the coal. But this coal-hewing society became such a grimy lot that its government resolved on a change. They now proposed that only about nne-fourth of the workers should remain at coal, while the rest were to be induced to go to other and usual rarieties of employment. In order therefore, to bring this about, they discouraged or excluded a great proportion of the importations by putting heavy customs duties upon them. This enabled home cultivators, whose small product previously would not have remunerated them, to get now such ligher prices from their own people as to yield them a sufficient profit. And so, too, the ontside world, finding the market for their own thing's thus narrowed, reduced proportionately their coal purchases. The result was a restricted production all round, indicated by the higher prices every one paid. The wages, which under King Coal's reign had been quite 20s. a day, were down to 15s., while the higher prices of everything practically further reduced the $15 s$. to $10 s$. But, then, the society was a rast deal tidier, healthier, and happier. They regretted, indeed, the half wages, but all else was in their favour.

\section{The Higher Price and Diminishing Lahour} Product under Protection.

As this Newcastle case shows, price is the inverse of quantity. When wheat, by an exchange, sar, of coal or wool, can be secured for $30 s$. a quarter, while $40 s$. is needed for that of domestic growth, that means that the same amount of labour which, 
under free exchange, secures forty quarters for the people's consumption, results in only thirty quarters by direct home production. This is a loss to the country just as distinctly as though an auriferous soil were cultivater, under pretence, let us suppose, of using the soil or employing the people, with the result of extracting $20 \mathrm{~s}$. of gold at the cost of $24 \mathrm{~s}$.

II. Albi, a noted French protectionist, held that to protect any one interest was, by the advance of price, a hardship upon all the rest; but that to protect erery interest gave all prosperity. But, from the preceding principles, it is not difficult to see that such multiplied protection, by which prices are raised all round to compensate for reduced production, is only multiplied loss in the ever-diminishing output of the labour. Indeed, it is fairly supposalle that, by a strictly applied protection in, for instance, a densely-peopled country like England, the labour product might be so attenuated as to prove insufficient to maintain in existence even onehalf of the people.

\section{Competition and Free Exchange.}

The principles of competition and of the subdivision of labour are fundamental to all economic progress; the one to brace up the worker for giving the largest or best labour product; the other for securing, under freedom of exchange, that larger market which ever increases economy of production.

To restrict the sphere of exchange, therefore, by such principles as, first, "keeping our own markets all to ourselves"; or second, "taking all our own 
wants out of our own soil, instead of other people's soils"; or, third, "not spending our own money upon other people's gools," is in exact contradiction to the three foregoing fundamentals of economy. Nor can we riew it as at all the intention of a good Providence, while so directly hurtful to economic interests, that mankind should be commercially exclusive instead of cultivating a mutual dependence upon each other.

Mills qualified Concession of a temporary Protection.

Lastly, Mill has quite properly admitted, that there may be particular cases, especially in new countries, where protection, for a limited time at first, may be beneficial, to establish some suitable interest which is afterwards to be self-supporting: Although Mill is extremely guarded in his conditional terms, this admission of his has been so incontinently abused by protectionists as to make it desirable that all such special and temporary aid should be simply by money grant from the public treasury, instead of by the indiscriminate and blinding mode of a protective customs duty.

\section{Case of Victorian Candle-making.}

The case, for instance, of candle-making in Tictoria, which arose under my own eyes, will be a good illustration. Tictoria, having the tallow on the spot, was bound, it was said for her, to make candles as cheap and good as, or even cheaper and better than, anywhere else; but that, at the first, the excellent imported article, which sold at $10 d$. per 
pound, could not be equalled, domestically, under a shilling. I protective duty of $2 d$. per pound was therefore imposed, and the colonial public had to pay a shilling instead of tenpence, in the hope that the colonial maker wonld soon justify his aspiration, or the aspiration made for him. Meanwhile such proportion of the imported candles as the public still took at the adranced cost inrolred them in no loss, lecause the additional 2d. went to rerenue; but, as to the colonial proportion, all extra price rent to the private maker. There is ret another point in the case, namely, that this $2 d$. of extra price inflicted on the colonists was probably much more than all the profit the protected candle-maker himself realised. But the climax of disappointment is, that the tax of $2 d$. per pound. after twenty to thirty years, is still levied; nor does there seem the slightest prospect of its being abolished or eren reduced.

Let us look now, instead of this old way, at my suggested new mode of the direct grant in aid. The colonial candle-maker requires a pecuniary aid equivalent to $2 d$. per pound, and that is to be giren him, as I propose, direct from the public revenue. The Colony's other vocations, let us suppose. rield an average of $10 . s$ a day to the hands emplosed; but candle-making, under free importation, would pay only 4s. a day. The Treasury, therefore, will supplement the other 6s. a day for all candlemaking hands employed. But this drain on the finances, common sense will suggest, must not last fur erer. It will be allowed for ten years, after which colonial candle-making must either stand on 
its own legrs or be given up. I will venture to say that, had this course been taken, colonial candlemaking, braced up by necessity, had probably alrearly been thus independent, which, however, it never will be, under the relaxing effects of its protection.

And, besides, one sees in this mode the promise of a complete suspension of hostilities between the two camps. If the matter lay with me, I would at once acquiesce in every protection asked for, provided it was given in this self-exposing way. Undoubtedly there might be great waste of public money; but the concurrent lesson as to the true bearings of protection would be so unmistakably clear as to be worth all the money lost.

The Argument with Protectionists.

Mr. McCrae, before mentioned, is here chicfly in the lead-off.

IIe. "New South Wales, I regret to say, is fast groing to the dog:s. Give to her interests the protection given by Victoria, and she may yet run alongside; otherwise she is to be utterly beaten."

I. "In which way?"

Ile. "In every way. She is behind in agriculture, behind in manufactures. She affords no protection to her own soil, to bring it into cultivation so as to produce her own wants. She buys instead the products of Victorian soil, merely because mercenary individual importers find them cheaper. She allows New Zealand to send in, perfectly free, her fine cheap oats at $2 s$. a bushel, at which they can never 
be grown here, nor indeed cultivated at all, without a high protection. In short, she is, by her neglect and indifference to her own interests, ruining onehalf of these interests."

I. "That seems a terrible category of woe; but I confess that I see nothing but advantage to the New South Wales public in getting so many good things so cheap. The Colony does not get them for nothing. She pays for them in other things-in other products that lie better to her hand."

He. "That does not tally with your great economists, who hold that all wealth comes out of the soil. Therefore, the more you get out of your own soil, the richer the country."

I. "Yes, provided the work pays. Would you work your auriferous soil for a crop of gold that costs you $25 s$. for every pound?"

He. "Of course not, but that is a different thing."

I. "It is no ways different. If you persist to grow oats, to cost $25 s$. a quarter, when, by means of some other product in a free exchange, you can get the New Zealand at $20 s$., you make the same loss as with the gold."

$H e$. "I don't see it so. In the latter case we are using our own land and employing our own people."

$I$. "You equally do that in the other case."

IIe. "Take another view. Yass, and down thence southwards to the Victoria border, can grow fair quality of hay for local wants; but, when perhaps there has been a good crop, Victoria floods us with cheaper and better hay, and then our growers can't sell. They won't continue growing hay in that case, 
and then Victoria, having all the market to herself, charges anything she likes."

I. "I have no faith in that sort of pat argument. Your hay-growers have surely common sense to look out for themselves. Your own public get the superior or cheaper hay; and they get it in exchange for other of your own products; they never get it for nothing."

Ile. "But Victoria won't allow a hale of our hay to go across to her people. Look at her stock tax, too. Her very best cattle come in freely to us, and she won't admit a single ox, best or worst, free to her own people. Parkes is a fool to go on with us in this way."

I. "To me the foolery is on the other side. If I were the Victorian public, I would insist on our having the New South Wales good things, instead of being sacrificed to the protection of the particular Victorian squatting interest. If any interest is to be protected, the first and strongest case is that of the whole people. Speaking roundly, every colonist is a worker. The best protection to all is to permit equal freedom of exchange to each."

$H e$. "Take the case of New Zealand. Would you take away the New Zealand protection just when the Colony is in difficulties and in a struggle to recover? That would only send her back again, instead of curing her of her trouble."

I. "Then you think that, when a colony is impoverished and depressed, the best help to give her is to increase the cost of her necessaries by compelling all her people to pay increased prices to certain of the local interests." 
He. "Well, that's one way of putting it, no doul,t; but how are the people to get employment, unless you provide something for them to do, by excluding the imports that take the work out of their hands? By aderuate protection they will, at any rate, have the manufacturing of their own clothing and boots and shoes, and the growing of their own food."

I. "I would leave them, in these and all other things, to look out for themselves. They certainly will do this if not officially interfered with. When you first arrived in New Zealand, of course your only idea was to go to the Gorernment, and ask them what they thought you should set to work upon, and how to do it?"

IIe. "No, I did no such thing. I looked about myself, and soon found a lot of prospect."

I. "And have continued to find it erer since?"

He. "Why, yes, in a way."

I. "But every other colonist is only a repetition of your individual self 'in a way' of his own. If you'll only leave him free, and not stultify his calculations with protective duties, hell find how and where 'to turn out the largest product of labour possible to the circumstances.'"

Ile. "I can't divest myself of protective ideas. Suppose every one protected, and so sulstantially as to insure most unusually ligh prices all romd. Wouldn't every one be prosperous? Prices could be sent to any height by merely increasing the protection, and excluding the competing foreigner."

I. "Yes, you had best go on to the mulutio rul, etc., 
and protect your North Island against the South, and rice repsit; then the counties against each other, the towns, the sulumls, \&c. The strife of liuman nature would cease, no doubt, but human exertion and progress would, I fear, cease with it."

He. "When you have anything to buy, why not buy it at lome, instead of buying it outside and benefiting strangers?"

I. "I would buy it outside if I coull do better. I exchange something else that my country produces, and thus get a larger product of what I buy outside. I am so much richer in this way by the free exchange."

II. "But the other side in most cases won't reciprocate, and where then is your advantage?"

$I$. "Oh, leare that to me; I have other exchanges to fall lack npon, and with these I square the account. There is no danger of my getting the foreign importations for nothing. They must be paid for, and all, more or less directly, in my comtry's own products."

He. "I encouraged a New Zealand paper manufacturer. He said, 'All I want is that you shut off the outsile competition, and I engage to supply the whole paper of the islands without raising the price.' He has done so. That has always seemed to me the very climax of protectionist triumph, and I am proud of it." (Sir H. Atkinson, the New Zealand Premier, is speaking here.)

I. "Yes, and the paralysing effects of your protection just set him to sleep where he was, when every other paper-maker in the world would, under the stimulus of free competition, hare greatly reduced the cost by such an extension of his market." 
He. "Then look at the life and bustle of Melbourne, with so many manufactures reared into being by protection, and which could not have existed otherwise, and could not now go on without the protection. What a creation of wealth, and what employment provided for the people! Melbourne has more population than Sydney, and probably always will have, under her protection."

I. "If Melbourne's chimneys and smoke arose in a natural course out of rocations that paid their own way, I would not object to them. But I do decidedly dislike them in your delightful semi-tropical climate, when they are created and maintained only by a heavy special tax upon the whole colony. The tax on woollen fabrics is 30 per cent., and on others $25 \mathrm{per}$ cent. What is the meaning of that? It means that for certain kinds of the worker's necessaries he has to pay, under protection, in the proportion of from $£ 125$ to $£ 130$, when, under free exchange, he could secure them for $£ 100$. If such 'protection' were more general, it would most seriously handicap Victoria's labour, and be especially conspicuous to her detriment, if she ran alongside of any other Colony which maintained freedom of exchange."

$\mathrm{He}$. "Well, as to that, you have read, no doubt, the remarks of the Chairman of our Sydney Chamber of Manufactures at the annual meeting this month " (Sept. 1888).

I. "Yes, I read a telegraphic summary."

IIe. "Quite sufficient. You saw what he said about certain manufactures begun there, and now on 
the decline for want of protection, and that the hands were leaving for Melbourne?"

I. "I noticed that; but go on to what followshis remedy."

He. "Don't fear; I had no intention to keep that from you. That, I think you will find, is my triumph, not yours."

I. "Good ; let us hear it."

$H_{e}$. "He points at two remedies; either, first, to increase the price of imported goods by an import duty to a point that would enable domestic interests, by an increase of price, to make production profitable; or, second, to lower colonial wages, until colonial-made goods can compete with those imported. He decides for the former remedy, because it would be a national gain, which would cost the country nothing."

I. "Then, if a farm or a factory fails, in quantity or quality of product, to pay its way, you have only to force up the price of the product by protection, and the country will know no disadvantage. If one of your soils yields twenty bushels of whent to the acre, while another, with the sime expense of labour, would yield only ten bushels, you have only, as to the latter, to increase the price adequately by a protecting duty, and the country is as rich, as well supplied in labour product, and as prosperous as ever?"

He. "Then, you go, I infer, for the alternative of lowering colonial wages till our labour can compete with the low prices of the imported goods."

I. "I do no such thing. Leave your workers and their exchanges free, a freedom your gallant old 
Premier is now fighting, day and right, to retain to them; and you may be sure he will find his own way to what yields him the best wages, and the best exchanges for the maximum of labour product in all the requisites of his life and his business."

Ile. "You are thus wholly opposed to any protective intervention whatever. But Mill allowed it in particular cases. At any rate, he concedes the principle. You dou't agree with him, then?"

I. "Under Mill's strict qualifications I entirely agree with him. But these you Protectionists always overlook. His concession brings him not one jot nearer to your abore said Chairman, because Mill's gist is that we submit to the present temporary loss caused by the protection, in expectation of rearing, in reasonable time, some suitable and selfsupporting interest. But your Chairman sees nothing but direct advantage in protection. The more the protection, and the higher the prices necessary to compensate diminishing ontput of product, the greater with him the prosperity."

IIe. "And yet look how Melbourne prospers. She has more energy and wealth than Sydney. Her agricultural products are pushed everywhere. She protects these also; all appearances are against you and your loose free trading."

I. "Well, your tirade is rather mixed; partly true, no doubt. The climate, comparatively invigorating, is appreciably in Melbourne's favour, as regards our race and its accustomed employments, even although by only some four or five degrees of the thermometer. Then the Victorian country is "icher and 
more productive, and even the smaller extent in area is for the present an advantage to Victoria over New South Wales, till population is much larger. For instance, the latter is now at great expense for railway connection over her vast areas, much of them sterile enough compared to her sister's. She has to bring in her resources from afar, while Victoria brings them from near; and, again, Victoria is less troubled by drought, a terrible scourge to her sister at times, cansing in some respects an absolute cessation of growth.

Separately weighed, these differences are not perhaps much respectively, but collectively they tot up very considerably in Nelbourne's favour. Protectionists must therefore, I fancy, be much astonished at the statistical comparison to-day, which shows that Victoria is being commercially surpassed by New South Wales. The latter, the senior by far in the earlier race, was beyond compare ahead of the junior up to the date when the gold delnge orertook them both. Then indeed the eight, ten, twelve millions a year of Victoria's gold, compared to the one million of her less fortunate sister, precipitated the former right ahead of her senior. During the first fifteen years that followed, Victoria's commerce, her public revenue, her population, and the far surpassing size and importance of Melloourue, which seemed already assured, even far in the front, as the permanent emporium of Australasian commerce, were all from one-third to one-half the greater in the comparison. The surprise is that this advance has not since continued, not even been maintained; 
for, although Victoria's gold has been seriously falling off since then, it is still about four times more than that of her rival. But what is the result to-day? For a score of years past the senior has been steadily recovering the lost ground. New South Wales has been already, for some years, ahead of Victoria in commerce and public revenue; also in amount of accumulated wealth she orertook and surpassed the other; while this year she has passed her also in population. Already the emporium of the Southern Pacific is Sydney, not Melbourne.

What is the reason of such a surprising turning of the tables? There is but one reason which I can see or think of; twenty-two years ago, Victoria entered systematically into a career of protection. That means that she then entered upon restriction, not expansion. She restricted the sphere of exchange of the product of her workers' labour, and by the certainty of economic law that product was diminished. As she purposely restricted her external commerce by the obstructions she put in the way of the outside trade exchanges, she must surely be satisfied with her success in placing her sister in the first position, and, albeit with inexplicable modesty, taking the second herself.

\section{The Conclusion, as I draw it.}

As the particular "He," to whom I delivered this concluding exordium upon Melbourne's economic forbearance and modesty did not reply, I am glad to save my reader's patience ly coming to a close. So I return to my friend, Sir Thomas, whom I left on the 
Exhibition floor, asserting, on behalf of protection, that we have found out many things since these bothering and contradicting economists. After all, I am disposed to agree with him, to this extent at any rate, that by help of protection we have indeed found out some things these said economists failed to see, although not looking exactly in Sir Thomas's direction. He evidently thought that " the two and two, making four" of the economists, had been somehow, by protection, increased to fire. But I think that it may be shown that protection so clips the integers, in the course of the addition or multiplication, that two and two make, not five, not even four, but only three. 


\section{SECTION XI. \\ Stdney to Brisbane, by Sea.}

For the present we had but two days to stay in great Sydney, a most insultingly inadequate time; but we had the prospect of three more days on our return, ere embarking for New Zealand. We were now bound for Brisbane, where we had quite a nest of relations. There had been a discussion amongst my party as to whether we should go by sea to the Queensland capital, returning by rail to Sydney, or rice rersî. A reputed fast steamer, the "Leura," happening to suit us as to time, we decided for sea first, and secured the best berths remaining, the ressel being fairly full. This decision was fortunate, for we learnt that, orwing to a two-knot northerly current inshore, the outward voyage is made close to the land, while the return is, for the same cause, far out to sea. The "Leura" is so called from one of the many grand spectacles of the Blue Mountains. She was about 800 tons, a fast sailer, trading between Melloume, Sydney, and Brisbane, but unfortunately in a very dilapidated condition, having her screw-propeller of four blades reduced, by accidents of tear and wear, to only one and a half, and having been so busily worked of late that the time could not he spared for a restoration of the gone flappers. So we holbled on, making. however, 
eight knots an hour, instead of the regular thirteen, by help of unsurpassingly farourable and delightful weather.

\section{The Neucastle Labour Strike.}

All our previous sufferings from cold weather-ant they followed us even into Sydney, where, as well as further south, the winter, as I hare already said, had been unusually severe-began now to cease as we passed northwarls into the ambient airs that were wafted off from Northern New South Wales and Southern Queensland. Te had left Syduey in the dark, namely at one o'clock A.M., and thus missed the grand and striking beauties of the Port Jackson Hearls. But these we had another opportunity afterwards to see. Towards noon next day, we were on the outlook for Nerrcastle, one hundred miles north of Port Jackson, which, besides being of importance, as a town and seaport second only to Sydney, was now on the eve of a condition of labour strike amongst the great coal interest which was to command the serious attention of this entire colonial group. The strike broke out on the third day, I think, after we passed, quietly and pleasantly, the smoky young city to our left.

I am not prepared to say much on the merits of this great strike, which, so far as I can hear at the different ports we touch at on our Home royage, is still as unsettled as ever after more than two months of halt in the ontput of one of the prime wants of life and business. But the subject in itself invites some remarks, and it is too important to be excusably 
passed over. The strike was entered upon within the last week of August 1888. It was commonly said by onlookers, who were not of the striking classes, that the cause could not be deficient wages, seeing that the rates paid for eight or nine weeks before were from $10 s .1 d$. the minimum arerage, to $13 s .8 \frac{1}{2} d$. the maximum average, for a day of six to seven hours' work. That high wage also, happily for its recipients, was paid in a free-trade country, which insured for the money the highest purchasing power. But that consideration had possibly but little to do with the real cause, and perhaps as little was that real cause what the strikers assigned at first, namely, some not very intelligible differences about parts of the seams which were harder than others to pick out, but not remunerated for proportionately. We may perhaps correctly suppose that there would still have been the strike had there been no such excusing differences, and had the rates of wages happened to be either lower or higher than they were. The strikes, in fact, are much more due to the temper and ambitions of the men, and if these are not regarded, and judiciously and, I may add, somewhat sympathetically dealt with, the striking will not only never cease, but be always acrimoninusly conducted.

Our whole English society is in the act of rapid transition from the old feudal or traditional class system, and the transition has already gone so far that the numerical political supremacy, both at home and in what are properly British Colonies, has passed to the masses of the people. That the political or 
"constitutional" surface is still unbroken, that the traditional monarchical forms still survive, and show no indication of being in danger, simply because they really do not, or at least they need not, oppose the democratic development, is due perhaps to a moderation of political character which is of the best augury. In every country or Colony of our Emrire there is still a Government which can, if it will, maintain order and the law; and which, if its individual components have the courage of their position for prompt, firm, and judicious action, will undoubtedly have the support of the great majority of the respective peoples.

These remarks are called for by the very savagery of some of the acts and threats of the Newcastle strikers. That a class of men upon whose daily work business and society absolutely depend for their very life should, if so minded, eutirely leave off work is what the others must submit to in a personally free society; but that these men, thus on strike, should prevent others, who were willing, from taking their place, is not to be endured while a Government stands. But, again, this infirmity of "temper" has at times with us, as happened, I think, even more than once in this strike, an irrepressible humour to-day and a penitent reaction to-morrow; so that the Oriental despot's short way of making peace might prove needlessly hard measure when, immeliately after, all might have come right without need for one drop of civil blood. This is where the quality of the judicious comes in; and I doubt not that my friend, Sir Henry Parkes, who never could, 
for one moment, have doubted of his porrer, has been thus somewhat equipoised in the great responsibilities of his position. As far as I could learn he seems to have acted judiciously under all the circumstances. But, speaking generally, if blood must be shed in order to quell unreason and passion, the quantity has usually to be increased the longer the final settlement is postponed.

Having said so much against the strikers, let me say something for them. I have remarked that rates of wages, good or bad in the abstract, have little to do with the strike question. My impression is, that strikes are much more frequent under good than under bad wages, simply because the workman is then in more heart, and is more bent on his rights; and his rights to him are, not good or bad pay as abstract wages, but what he thinks should be his proportion as between the two parties concerned, the employers and the employed. If this were kept in view, still more if the principle were cordially recognised by the former, there would be much less striking, or, at any rate, much less bitterness in the procedure. The workman should not be taunted with having enough wages already for his wants, \&c., \&c. When the merchant, the doctor, the lawyer find themselves well off, is that the time when they moderately think of reducing their charges, or even of keeping them where they are? On the contrary, they raise them, and the more they get, the more and still more they ask. And so with the workman. It should never be put to him that he has already chough wages for his wants, becanse that is to-day 
ahoolutely no real part of the strike question. He often, indeed, miscalculates his position, and has to smart for such serious mistakes by heing senerally beaten in the eontest: and he often also behaves so batly in the fight, that he still more deserves to lose. Indeed, he can never expect to make much of it, unless he cin institute some higher code of homour in the Unions, so as to Hring a stronger hand upon those intemperate memhers, who are ever lininging in the police and military, to smish down their efforts and make a fool of their principles.*

\section{The winding River Brisbane.}

We had the double misfortune of learing sydney IIarlour by night, and arriving hy night in the Brishane River. We nisserl seeing the fine spacious Moreton Bay, sheltered by Stradbroke and IInreton Islands; lut the winding Brishane took ns some hours to accend, and day broke orer us half-way. Te passed what secmed to lie a great village, and which, as we thought, must he far helow Brisbane, because we had still annther hour of river-winding. But this turned out to be a part of Brisbane itself, namely, The Talley, near which some of our relatives resided, and who were at the time rigorously hailing

* After nearly three months' continuance, the strike was lappily ended, as the following telegram, dated syiney, 15th Nuremher, intimates: "An agreem"nt between the masters aud the colliers on strike has been signed, and consequently all the miners will resume work forthwith. The strike in the Newcastle coal district which commenced in Augunt last is thus ended." 
us from a neighbouring rerandah, but without our noticing them or even suspecting their near presence. At last we pulled up at the Custom House, a presentable little temple-lonking edifice, where one of our nephews a waited us with a vehicle, which was soon rolling us merrily along through town and suburbs, some five miles out, into what were to us the heretofore unknown regions of Queensland. 


\section{$(131)$}

\section{SECTION XII.}

BRISBANE, 'I'HE CAPITAL OF QUEENSLAND, ANI)

ITS NEIGIIBOURHOOD.

I IAVE two sisters in Brishane, settled there in the hippy accidents of life. both with fimilies, and one of them alreaty with families' families. My frient, Mr. Plimmer, the surviving patriarch of Wellington, $\mathrm{N}$ (W Zcaland, of whom I have presently to speak, toll me. that he had alleaty eightr-five of a fimily in this duplicative way. For the loreeding of rablits, sheef, and humanity nothing beats Australia and New Zealand. I think I am not unreasonable when, later on, I am to suggest that, in a century hence, even this wide and now all but empty Australasia may feel overciowded, and go out for cllow-room upon her beautiful semitropical ocean in the great vessels of that not very firr-off time, which will probably resemble huge hotels floating sately, stcadily, pleasantly, and with express speed, as need be, upon the azure main.

Wre were delighted with everything in Queensland. The climate, at that early spring time, was all we could wish. It was deliciously cool at night, so that I rolled myself in double blankets; while in the day, although the sun was at times hot, showing what it might be when more rertical in summer, the air was most genial, like a later spring day in South England. 


\section{Good Streets and Buildings.}

Considering the youth of this place, I was as much surprised at its appearance as that of Sydney and Melbourne. Including the suburbs, it has alrearly 75,000 of population, standing thus next to Adelaide, and being the fourth city of the group. I was equally surprised with the advanced condition of its clief streets as to banking, commercial, and trading linsiness. A feature here, as indeed in Australia generally, is the competitive spirit, and of the banks in particular, for grand edifices. The Queensland National Bank is not excelled anywhere in these Colonies; and hardly behind it, if indeed at all behind it, is the Brisbane branch of the London Chartered Bank of Australia. There are, hesides, some great warehouses, particularly of that leading Colonial branch, the Soft Goods trade. The Gorernment House, the Parliament Houses, the Club, are all fairly presentable, while Queen Street, the main banking and business emporium, squares well up already towards the busy aspects of her senior rivals down south. There were busses and trams everywhere, and the smart step and preoccupied expression of the many citizens told that their young city had already emerged from the leisurely ways of village or country-town life. In fact, I was fast arriving at the conclusion that Brisbane was at once the youngest and, relatively at least, the most go-ahearl of the city sisterhood. 


\section{The Charred and Dead Trees once more.}

As to this fast-running young lady of a colony several things struck me. First, as to the physical aspect, the comntry was prettily undulated with liills, covered top to toe with forest. Driving to the tup of Mount Coot-tha, a hill several miles from town, and about 700 feet above the sea, we had a beautiful view to the fir interior, beyond Ipswich to the west, with MIoreton Bay to the east. But these forests, when we afterwards drove through some of them, were the sarklest, ugliest, and most desolate scenes of their lind imaginable. Noarly all the trees had leen scurched by repeated fires, some of them to death, others to a dring state, and many to a half-life struggle that hiad far better been ended from the first. No tree had attained to any great dimensions. I sprinkling here and there had escaped, and had the natural grace of the gum tree; but mainly the scene was an ugly crowd of the dead and dying. I pointed out, too, that it was a dangerous as well as a deformel case, for, when fire did come to or arise amongst all this closely packed dead and dying: timber, it must be extremely dangerous to those great wooden suburbs that respectively sprawled out crer a square mile or so of Brisbane's vicinity, and in any of which a thousand cottages might be burnt down within a few hours. I brought up again my remedy of the great steam-sawing machine, which might soon hare cleared many square miles of an ugly crowd of stunted forest, turned the country, in spite of a rather dry and sterile soil, into much more 
of the Australian park-like aspect, and made the near as well as the distant view to lend its enchantment to the pleasant scene. But, rather unfortunately for this idea, all the land hereabout had long ago been sold by the Government. It brought very little money at that early time, compared with the prices now "booming" all about.

Secondly, these prices of land, town as well as suburban, surprised me. $£ 300$ to $£ 700$ an acre was being given for land at the distance of three or four to six or eight miles from town, and most of it land but little worth for farming cultivation, and thus available chiefly for private dwellings and gardens.

Want of Capital for Land and Mining Development.

Thirdly, there was a cry everywhere for money, for more capital, to derelop mines, or help enterprise, or extend business generally, in the direction, for instance, of converting private interests into "Limiteds," by help of capital obtained in London. This could not be done, because the London market was now too suspicious of the unconscionable game of orer-valuations that had been heretofore carried on against it. At home we had rather the idea that Queensland had been already quite overdone with banks and loan companies; and we might, besides, point to a Mfount MLorgan gold mine, at sixteen millions of value now for what had cost originally a few hundred pounds, as one indication at least of the wealth and independence of the Colony. But the fact was that Mount Morgan had as yet brought 
nothing to the Colony beyond a mere income or dividend. Anything beyond this was entirely as yet in prospect, while, if any of the more lucky of the speculators bethought himself of clearing out, through fear of bad luck for the next turn, he drained the poor Colony in taking his good luck with him. "We have unknown quantities of mineral wealth here," said many to me; "the surface as yet is but scratched, but we can't get the capital to develope the wealth." So I set myself to consider how this evil could be remedied. The London market has heen so often deceived and cheated that it has lefinitively buttoned up its pocket. INow are we to get it to unbutton? I gave attention to this sulject up to leaving Melbourne, and will revert to it once more.

\section{Brisbane Waterworks.}

Having only nine days to stay with our relatives, sight-seeing was rather restricted. Mount Morgan, five hundred miles off, and without a direct railway, was of course out of the question. We accomplished but two short trips, one to the Brisbane Waterworks, eight miles off, where the little Breakfast Creek is dammed up into a pretty sheet of water, covered with various indigenous birds and surrounded by pretty woods. Here we heard, amongst much other active life, the note of the bell-bird, once plentiful around early Melbourne, but now, alas! with name and note never heard thereabout. There is yet another water supply further inland, and as the capital extends in size and population this thirsty 
climate will require still more. Most of the suburban cottages had, for the present, to look to themselves for water, and commonly had each a great galvaniserl iron cask, or tub, or tank, whichever you prefer to call it, to gather up and preserve the rain water.

We had made a party to drive out to the waterworks, where we had gipsy tea and suitable accompaniments, besides a small herd of cows and calves humbly waiting on us for our orange skins, which they greedily devoured in preference to the dried-up grass. But Sandgate, our second trip, we took by rail. We passed and re-passed a little creek by the way, which, as is not uncommon with Australian creeks, makes a most pretentious outlet into IForeton Bay just behind Sandgate. Sandgate has not much of display as yet, but it has, what is of great value to Brisbaners, the sea and the sea air. I was disappointed at finding no fine shells. One of my hobbies from boyhood has been shell-collecting, under the high sense which it conveys of the wealth and beanty of form over the world. Whenever I touch an unknown shore I am off to see its shells, and it was rather disappointing in this case to be so near to the tropics and yet not find any; for, excepting a very ordinary whelk on the rocks, there seemed alsolutely nothing worth looking for. I was told, howerer, that outside Moreton Island, upon the open Pacific shore, there were plenty of beauties. Farther north, towards Torres Straits, the shells, together with limitless coral, are magnificent. Sandquate has a fairly passible hotel, some spare residences of merchants and bankers, incluling no muresentable 
one of my friend, Mr. Drury, the head of the Queensland National Bank, and unlimited future prospects in connection with the expanding future of her mother, Brisbane.

Alas! our pleasant days, and even pleasanter nights in Queensland soon ran out, and once more we must be on the wing. We could only spare about the same time for seeing all New Zealand as we had given to Brisbane and neighbourhood. We quitted a busy scene, and a vast one too, if we looked to the area of the Colony; while, beneath the varierl surface, lay almost everywhere incalculat, le mineral wealth. Only some of this mineral wealth was but just touched, Mount Morgan for instance. Huw many more Hount Ilorgans might turn up if the colonists could but get from the Home market the ready means to develope them! So once more I promised to consider what could be done in that direction. 


\section{SECTION XIII.}

\section{BRISBANE TO SYDNEY BY RAILWAY.}

\section{Quensland Traders "threatened" with Protection.}

TuE mail or express trains have a bad habit of starting in the night, so we could not see Ipswich, a considerable torn up the Brisbane River, nineteen miles from the capital. A connection of ours, Mr. Chubb, senior, a leading man there, met us. He lianded us a small rolume of his own poems; but, although they were not bad reading, I was more interested about certain woollen and other manufactures, which he had to do with here. I asked if he was protected. No, not yet, but he trusted that his friend McIlwraith's wisdom wonld soon do the Colony justice in that way. I asked him how he carried on the work if it would not pay without protection. Oh, it does pay, he said, but we want protection to extend it still further, and to give us and all the Colony the benefit of the high prices. The old story, thought I; but I had no time to dig up the confusing mud of that sulject. I contented myself with telling my friend that at a large machine-brickmaking and coarser pottery work, which I had lately visited, where they had already more orders than they could possibly get through, they did not want protection, albeit always threatened with it by hoth. MfeIlwraith and his political opponent 
Griffitl. I advised them to do withont it. With it, they would get gradually stilten up into an artificial position, which miglıt so undermine their compretitive energy, that if in overstock at any time they would have but their own home market to fall back upon; while also, if the Colony altered its policy, they would be left high and dry, to get lack to the old solid ground as they best could. They seemed to me to agree with this view.

Our line from Ipswich makes a great detour hy Toowomba, instead of a direct comrse to Warwick. But, no doubt, the latter will come soon. Meanwhile the interior line continues to an immense distance, namely, as far as the River Warrego, one of the many head-waters of the Darling, four hunched miles from Brisbane. Brishane must next direct her rail line to Rockhampton and Mount Morgan, muless indeed that latest of the greater gold mines has been entirely over-estimated.

When the morning light overtook us, we had passed already into New South Wales. We were suon after at Tenterfield, one of the usual sprawling inland towns, the one the copy of the other, but in this case with some pretensions to size. There wals the newspaper of the place too; but, as its price was as much as 6u., and not that very morning's issue, we were not attracted to buy a copy. We were leginning, however, to feel like Londoners, who can't tolerate provincial papers till they get into the proviuces, when they feel willing to condescend to take such secondary gear, if only for the sake of their morning's telegrams. And so we were ready 
to buy, only that we did not happen to meet with such a provincial print the whole way. Night had come on again when we passed Maitland and Newcastle, the big places with daily papers and telegrams, and at the now royal price of a penny.

\section{Australian Scenery once more.}

Throughout the long day we passed abundance of the everlasting old type of country, that is to say, grass-corered, alleeit rery thinly in most places, and with an open furest in the plains and hollows, a considerably thicker forest upon the hills, and throughtout the whole scene the usual large proportion of dead and dying trees. Oh, for my huge sawingmachine once more! How I should set that at work if I were Premier of the Colony, just to see how even one square mile of it would look after its "redding" up," as we say in Scotland. Fair Australia would hardly know herself under her new top-dressing. There were everywhere signs of drought. Excepting a refreshing shower or two, but of wholly inalequate character, there had been drought since February, no less an interval than six months. We passed few sheep, except near towns, where there was occasionally considerable irrigation, and fine green fields. But a good many cattle were visible, some of them thin and weakly. Hore than once we saw a poor young calf or young cow, which had got into a miry remnant of a pond or waterhole to look for water, and, being too weak to extricate itself, had lain lown in the mud to die.

We passed some fine hill scenery on this second 
day. To my mind, which had always the economic turn, these rast areas of our Eimpire, as we now raced through them, kept me in constant thunght and admiration. Some day, in the world's progress. mere area would take leal as the highest of valnes, lecanse, in the progress of science and husiness. anything and everything could be made out of it. With irrigation orer that rast surface, her nowerful sun would grow anything, and make it the great factory for every human want to the whole world.

\section{Great Rail Bridge over the Haukesbury still unfinished.}

There is still one break in this long line of seven hundred miles, and that is at the great opening of Broken Bay, the mouth of the River Hawkesbury. As our bad luck would have it, we came once more upon one of our grandest scenes, as this truly i.s, by night; but it was so close upon dawn that we were happily orertaken by daylight ere we had passed the series of beantiful bay recesses, the worthy rival, on its greater scale, of beantiful Port Jackson. The effect of the small harly evergreen scrub and bush which corered, with ever deceptire effect, the sterile sandy soil beneath, was most lively and pleasant. A smail steamer took us sereral miles up the Pay from a temporary railway terminus, and on the way we citught sight of the great "cantilever" stretches of modern engineering slill, which, as with the concurrent constructions across the Forth and Tay at Home, bridge over vast chasms, which. even to the 
last generation would have seemed unattainable miracles.

Now, as we sped along, we knew that we were approaching population and markets, and civilisation generally, for on each side of us were comfortable and pretty cottages and villages, with gardens and orchards full of orange and other fruit trees. The oranges must hare been in season, for the trees were in most instances loaded. Altogether it was a pleasant scene, and, but for the too evident drouglit every where, would have been much more so. Shortly before $1100 n$ we reached the considerable old town of Parramatta, and were in a few minutes more passing a second time through the many and wide Sylney snburls, into great Sydney, mistress of the Sonthern Pacific. 


\section{$(143)$}

\section{SECTION XIT.}

SYDNEY ONCE MORE, AND THE BLUE MOUNTAMS.

TTr: had three whole days to sprent this time in syluey. What should we do with them? how sienul so much time? When we went for a family visit to limne for the first tine. and had lunt four days at our command, my juke was that it proved too much. and that we did not know what to do with the balance. But really the grand historical ruins of the old Tepululic. "1p to the time of Julius Cusar, are huddled together in a very small space, chiefly in and immerliately arounl the Forum, the great extension of Rome having come with the emperors. Those precions old ruins we. with a smart guide, saw all in one day. IVe took st. Peter's and three or four chief churches the second day. The third day must needs be giren to shops and photos, and the fourth puzzled us to get through. Sydney, therefore, could be "done" in three days. Wre paraded George Street and Pitt Street one day, looking into shops and selecting photos. The next day we went to the Blue Inomtains; the third day to Manley Beach; and the thing was done.

\section{A very Old Friend.}

I had time to call and resume acquaintance with my very old friend Mr. Augustus Morris. who wats me of Tietoria's rery earliest colmuists, having 
crossed from Tasmania in 1835, very soon after Batman himself, and taken up a squattage in beautiful Colac, where I met him, and enjoyed his bush hospitalities as far back as forty-six years ago. We reciprocated compliments on each other's appearance under the load of so many rears. My friend had quitted pastoral nceupations for some time. His active turn has made him useful as a public man in such things as the Colonial Exhilitions out here and at Home. But now he is quietly settled as a Commissioner of Insolvent Estates, and seemed rather to grumble that, oring to the goodness of the times, he did not make quite so much as he might otherwise have done. As a good economist, looking to the interests of the largest number, I had some difficulty in sympathising with him on that point, but we made up for that by agreeing in nearly everything else, including the free-trade question.

\section{The Famous Blue Mountains, and Katromba Tounship.}

Although I had been in Sydney several times, from 1841 downwards, and, twice over, had stayed weeks or months, as representative for Mellourne in the early Legislature prior to Victoria's separition in $185 \mathrm{l}$, I had never yet been to see the famous Blue Momntains. But then, in those pre-railway days, a visit there was a tough and protracted job. Now we could be whisked up in two to three hours, free from fatigue and with complete comfort. By learing towards evening, we got nearly all the day for Sydney, hut that involved of comse onr staying the 
night at Katoomba, in the midst of the mountain range. We would pass along the "Zig-Zag" rail on the near side the Hills, but could not reach the descending one on the far side, which is much the grander of the two, as that involved too much time, at least if we must also see the Katoomba vicinities, and the famous scene called Goret's Leap.

We reached Katoomba so late that we made straight for our beds. The next morning I was up and about before breakfast, as usual with me, to see the neighbourhood, and enjoy the sharp, bracing air of so elevated a position. After breakfast we were to take the grander sightits. Katoomba is as much as 66 miles from Sydney liy the détours of the railway, but sreatly nearer "as the crow flies," so that in an extra clear day Sydney can be seen from one of the adjacent heights. A very large hotel fronted us at the station. A number of men were lard at work to make it still larger. It aspired to a hundred and twenty beds-no small pretension in so young and still so small a town, with not more, I should think, than seven to eight hundred people. But in the full summer season, which was yet two months ahead, there was a prodigious pressure of visitors; and no wouder, for Katoomla stands on one of the loftiest elevations of the Blue Range, being about 3,350 feet above sea-level. We experieuced, during the night, what that elevation can do in cooling the air, for I had to wrap myself in a warm woollen night dress, and to superadd our railway rug to the couple of blankets mercifully provided lyy the host.

We found two or three other, although not quite 
such pretentious, hotels, and on quite a number of houses and cottages were tickets intimating board and lodging. The public school too was at full work. Little troops of boys and girls, with their satchels, were enjoying a romp to rary the home trudge after those tiresome lessons. But the tiresomeness of the lessons certainly added vivacity to the romp. I found a prodigious mass of soft black délris like coal, which had been used to bank up the railway, and into which I incontinently sauk, as in a quicksand, nearly to the knees. This came from an adjacent coal pit, which seemed to be still at work. It was curious to fall in with coal so far away up in these sandstones. But Australia, alike in her gold and her coal, runs, in some respects, full tilt against the old ideas. She lias coal in the oolite instead of the orthodox carboniferous series, and, with her sister New Zealand, she graduates in lignites almost, geologically speaking, down to our own day.

These Blue Mountains are not a mere hill range, which, howerer preeipitous and difficult, multitudes might have easily crossed. They are a great north and south mountainous belt, some thirty to fifty miles in breadth, and full, at once, of the grandest and the most untraversable scenery. This explains how, fur many years, almost, in fact, for a whole generation from the founding of the Colony, they were regarded as impassable. The grandsires of the prescut occupants had begun to make up their minds that the tiny strip of some forty miles between the two Blues of ocean and mountain was all that they could reckon upon enjoying. This lasted till 1814, 
when three super-arerage resolute, youthful spirits, Blaxland, Lawson, and Wentworth, all of them afterwards distinguished in the Colony's history or politics, the last in particular, burst through the mysterious barrier, and opened to the people those vast pastures of the far west, which have since created the main staple of New South Wales commerce.

After breakfast we engaged a carriage, and were off to Govet's Leap, some thirteen miles' distance, I think, intending to take the Katoomba sights, not quite so grand, but only a mile or so off, after we returned, and before luncheon, and then take our final leare, about 2 P.M. by the rail. Ere, as it seemed to me, we had quite finished our mileage, our driver halted, and sent us down a slight bush track, which, he said, would take us to Goret's Leap. On we went, but after a quarter of a mile our track ended in several hardly discernible continuations, where there appeared to have been some cutting down or barking of trees. We had, however, reached the brow, and beneath and in front of us were spread out vast gorges or valleys, forming, indeed, a grand spectacle, but with nothing in particular that could be called Govet's Leap. We loyally trusted, however, that our driver must know better than we did, and so we concluded that a small precipice far below was the Leap, and that it might look more pretentious when a rainy season gave it some water. On returning to our driver he confirmed our loyal conjectures; but we afterwards learnt that we had entirely missed the grand scene, and that the young fellow, being a new hand, had never been at the place before. We 
had noticed him cousulting at times a rough sketch upon a card, which his employers had vainly given him for guidance. Trips from Sydney to Katoomba are now easily and cheaply arranged, as we afterwards learnt to our regret. We paid the unconscionable charge of $£ 2$ for our vehicle, and withal missed seeing what we had paid for so dearly.

But we had some amends in the Katoomba scenes. These were truly grand. We followed the pretty Katoomba stream, still with a good tide of clear water in spite of drought, to where it leaps down a rast precipice into the abyss beneath. Below us were some fifteen hundred feet to the bottom of the gorge, and above us were still some liundreds of feet of further precipice. Then people hear much of famous scenes, the reality often disappoints them, but I found that my anticipations fell short of the scale and character of what now opened before me.

\section{Sydney Harbour : Manley Beach.}

Our next and last sight-seeing was to Manley Beach, at the north-eastern extremity of the Harbour. One of the little pleasure steamers took us there and back in three hours, with an hour to spare at the Beach, by which term is, no doubt, meant the ocean beach which a few minutes' walk brought us to, across a narrow neck of land from Manley Bay. There we sat, sniffing the sea air and looking out upon the limitless waters. There are some enjoyable sights and curiosities here. The little town of Manley has but one strcet, extending from sea to sea, but it presents a considerable variety of enter- 
tainments for the crowd of citizens who frequent it, chiefly in summer and on Sundays. You can get, in several places, tea ì la Chinoise, with real Chinese tea, drawn in Chinese fashion, and taken out of Chinese cups. Oysters and other shell fish superabound, and for those who want still higher resources, there is a very presentable aquarium, with selections chiefly of the bright-coloured transparent little fancy fish of that sunny region of the world. We had a good view also, as we both went and returned, of the grand opening of the Port Jackson Heads, the northern of which is a small peninsula, with the Manloy neek as its narrowest part. 


\section{SECTION XV.}

SYDNEY TO AUCKLAXD, N.Z., BY THE "FRISCO" MIIL. WE regretfully wound up accounts with Sydney. We had taken, in due time, our passages by the "Zealandia" as far as Auckland. These passages could only be contingently assured to us, howerer, as any passenger going on beyond New Zealand had a preference. Fortunately there was not such pressure as to leave us ont. We got fairly good berths, and we had a very quiet and pleasant passage. A party of our friends, by way of a farewell, escorted us as far as the Heads, in the Gorernment steam launch, which my friend the Treasurer had complimentarily granted to Mr. Cash Neild, M.P., and Captain Rounding for the purpose.

The "Zealandia" was not large, only 3000 tons, but she had a delightfully spacious deck, and, as the weather was fine throughout, we much appreciated her accommodations. Our captain was a German, an intelligent but quiet, unpretending man, with a head like Humboldt's, and a face and general physique remarkably like those of his lately departed old Emperor. The "Zealandia" herself was of American ownership, but oddly tied up under American Shipping Law. She can't hoist the American flag because not built in America; while, again, America can't build ships, to face outside competition, owing to her paralysing protection; so, of necessity, the 
foreign-built, American-owned "Zealandia" creeps into shelter under a Honolulu flag.

\section{Grand Sea Approach to Auckland.}

On the third day we rounded the Nortl Cape of New Zealand, which terminates a long neck of land, stretching into the delicious sub-tropics of between $34^{\circ}$ and $35^{\circ}$, a latitude which, with its ocean surrounding, insures the paradise of climates. We had passed the North Cape in the night, and as the morning broke we were already approaching the Bay of Islands, with its prettily placed small subcapital town of Russell. Beauty succeeded beauty as we passed on. The islands of the Great and Little Barrier arose on the remote horizon, and presently we entered the grand Hauraki Gulf, which gives such a magnificent sea approach to Aucklaud. Then Sir George Grey's pretty island, Kawau, was pointed out to us on the right, a property which we were informed he had lately sold for $£ 12,000$, surely a very inadequate price. But Sir George, we heard, had taken to flight, in consequence of the Government's resolution to tax property. The Government hau been driven to this at last in sheer desperation to get sufficient income. ()ld, wealth accumulating, conservative John Bull does not like this. Hitherto, the workaday man and his yearly earnings had been chiefly taxed. What is the good of wealth, he growls, if it does not secure you influence enough to beat off the tax-gatherer? There had been, however, a hard time amongst New Zealand property-holders from the late serions fall in values. 
Climate and various Attractions of Auckland.

The feature of Auckland is surely its verdure; at least that is what strikes one's eyes, as they are immediately transferred from droughty Australia. One conspicuous hill in the immediate foreground to the east of A uckland was so intensely green as to look as though artificially painted in such extreme. All about were small very green knolls of bills, including Mount Eden, just outside of Auckland, all of which, as we learnt afterwards, were old volcanoes. There were some two dozen of these "uneanny" features, suggesting what a brisk time of it there must hare been hereabout in past days, and also whether that sort of thing was as yet altogether done with.

As directed by friends, we went to Cairn's Hotel, where I found the landlord, with his high Scotch name, to be an Edinburgh fellow-townsman of my own, whose father's shop in Preston Street, Newington, I recollected repeatedly passing in my boyhood when I rent out bramble-gathering to Roslin. So we had a pleasant chat upon old scenes. There was another pleasant meeting, and, in an amusing way, suggestive, once more, of a Colonial progress ahead of our half-sleeping old Mother. While turning over photographs in one of the shops, we asked the people there if they knew the Rev. Mr. Bergh, R.C., one of our fellow-passengers by the "Coptic," whom we expected to be already hereabout, and whom we had found so excellent a fellow, that he might be almost taken for a good Protestant. They promptly answered that Mr. Bergh was staying 
with the Arclibishop, and, as he might be there at the moment, they would "telephone" him. There he was truly, and he responded at once, accepting our invitation to luncheon, with an afternoon's drive to see the city.

We had but a short time, two days only, to see beautiful Auckland. No Australian droughts had penetrated here. It was one ubiquitous emerald. Our finmed Emerald Isle hal here, in this Northern New Zealand island, a duplicate at once larger and with a vastly finer climate aud scenery. Auckland is a big place, with as many as 60,000 people. But it has been rather overbuilt during the last few years, and the late protracted commercial depression has been perhaps greatest here. Some bankers and others donbted if the depression were still past in this quarter, although elsewhere in New Zealand it secmed to have already bottomed. Since my visit, that supposed great Auguan Stable, the Bank of New Zealand, speaking in a banking sense, has been cleared out, or cleared up, so that the actual business horizon is now more distinctly made out. New Zealand will probably now enjoy a beneficial reaction, when the whole accounts have been all settled, and properties, previously "bung up under business embarrassments" have passed to free and solvent hands.

Our landlord boasted that Auckland was the third city of Australasia; but Brisbane is considerably aliead already, and in a hopelessly beating race, while Ballarat in Tictoria, and Newcastle in New South Wales are likely soon to follow. Auckland 
is, however, as yet, the largest in New Zealand, although I fear it is to be overtaken by both Dunedin and Christchurch, as the great centres of the Colony's grain and frozen meat trade, and perhaps even by Wellington, with its grand central position. The great attraction for Auckland is its climate. It is the Naples or Capua of New Zealand, where retired and leisure people, not bothered with daily toil, may eat lotus leaf as of old, and thus anticipate Paradise.

Our view from Mount Eden was magnificent of its kind. It was not mountainously grand, but surpassingly rich and diversified in landscape, with the grand Hauraki Gulf on the east side, and the landlocked Manukau Harbour on the west side. We were to leave the next day by this harbour, to which a short railway of six miles takes us from Auckland. We had decided to take the West Coast route to T'ellington, as not only the most direct, but that by which we would see most places, such as New Plymouth and lofty Mount Egmont, Cook's Strait, Nelson, and Picton. The landscape was dotted over with the small green hills or knolls which I have alluded to as extinct volcanoes. Of this there can be no reasonable doubt, as in most of them the crater feature is abundantly evident. Mount Eden, for instance, had a most marked crater, deeper, if I recollect aright, than the hill itself from the level immediately surrounding it, or perhaps 150 feet, the bottom being well sprinkled with volcunic-looking stones. In every part of our drive the land was rich and abundantly grassed. I asked the price of land hereabout, several miles outside of Auckland, think- 
ing that in these bad times it might be had cheap. But no, people thought so well of it, and of eventual prospects, that nothing under $£ 100$ an acre would be listened to by its owners.

The feature of the town is the wooden house. The chief business street has many fairly fine stone and brick edifices, but everywhere "cheek by jowl" is the wooden stmucture, holding its own in prompt and cheap construction. This is the centre of the great kauri pine trade. This pine does not exist out of the Northern Island, and the northern half of it yields the best. There is a small or bastard pine of which forest jungles all over the north, and the south island as well, are composed, but this is an almost worthless tree economically. Great sawing works of the true pine had been established, some of them many years ago, over the North Island; but an a rule they were not successful, possibly because involved in the late bad times. A large company at Mellourne, The Kauri Timber Company, Limited, has lately bought up all these interests, together with a great deal of land, under both lease and purchase, and it is now to be seen how the new hand fares. In point of contemplated scalc and of capital there is a farourable prospect. They have expended already about three quarters of a million.

I remarked, however, that another tree was everywhere rapidly pervading New Zealand, namely, the Blue Gum of Australia. In the Colony's fine clinate, and with adequate moisture, it grows with marvellous rapidity, and has a comparative fulness of foliage and a grace of form which make it orna- 
mental and popular. Everywhere we met it planted along the roads, and as a surrounding to private grounds, and in pretty clumps in parks. I was reminded everywhere of the different fate, to which I have so repeatedly alluded, of poor gum trees of all kinds "on their native heath" from the droughts of nature and the neglect of man. 


\section{$(157)$}

\section{SECTION XVI.}

AUCKLAND TO NEW PLYMOUTH, PICTON, AND

WELLINGTON, BY SEA.

TAkisg rail to Manukau Harbour, we embarked in the Union S.S. Company's "Penguin," a ressel nothing pretentious as to size in these ambitious days, but a good safe sea-boat, as me found the day after in a terrific squall in crossing Cook's Strait. Tre had a fairly pleasant passage as far as New Plymouth, where we arrived at early morn. Being generally an early riser, I was rewarded by a glimpse of the summit of Mount Egmont, rising like a bright white rather narrow triangle, above the subjacent thick clouds, with the rising sun glinting on it. Half an hour afterwards it passed into its more usual cloud envelope, and during our brief stay could not be wooed out of it. It is at times quite distinct, as seen, from the Southern Island coast, 120 miles away; and no wonder, seeing it is about 8,300 feet in height. But, even at this elevation, it is not the highest point of the North Island by nearly 1000 feet; while it is still 4000 feet below Mount Cook of the Southern Island.

\section{The Premier and the New Plymouth Harbour.}

I had had, at Auckland, a telegram from Sir Harry Atkinson, the Premier, through his private secretary, Mrr. Leckie, that he would meet me at 
New Plymouth, his usual residence; and now, on arrival, we met Mr. Leckie, a favourable specimen, well mannered, well put on, of a young colonist, who took my wife on to town by the rail, my daughter and I, along with others from the vessel, preferring a mile's walk in the fresh pleasant morning. I had the pleasure of a deal of talk with Sir Harry, who had his troubles with his Parliament, particularly in matters of finance, and still more in that cross-grained concern, the New Plymouth Harbour, which threatened already to silt up, and thus render nearly $£ 200,000$ of expenditure just so much money thrown into the sea. "Whatever you do, or don't do, in the matter," said I emphatically, "don't default, even temporarily, on the New Plymouth coupon, or you will never hear the end of the matter; and eventually, when, after all, you must pay it all the same, it will cost the Colony, as the effect of discredit, fifty times the small annual sum now involved."

New Zealand had been most disparagingly attacked by some of the London papers about her heavy Government debt from over railway-making, and her uliquitous borrowing besides, in mmicipal, harbour, and individual interests. But the payments, in all cases of a public kind at least, had always been punctually made. Now this threatened default of the New Plymouth Harbour was to start the Press once more on their raid, and with at least one good proof in hand that they had been speaking only the truth. The New Plymouth case was this: The Government promoted a harbour there as a 
Colonial object, there being no other near on that exposed western coast. But nature had rounded everything thereabout with her stormy winds and waves, and it was somewhat difficult to put a spoke in the wheel of her wilful career. A pier and break-water were, however, constructed, under the best availatile engineering advice. They lave been built, and they are found "no good," and it is just a question if the whole affair, on its present basis at least, must not be entirely thrown up. Well, when is to pay the piper for such an abortion of a song?

Sir Marry's Parliament inclined to the opinion that the Home investor accepted the risk and must stand by it. He got 6 per cent. interest, which no one could expect from a thing free of risk; and, besides, the hond itself said plainly that the Colonial Gorernment were in no way liable. "And yet," replied I, "you project a public olject, put out a sort of decoy report-for that is how it will be riewed - that the work is feasible, get the money from trusting investors at Home, and then tell them that your own engineers liave unfortunately been mistaken, hut nome the less that these Home investurs must stand the loss."

Sir Harry did not exactly dispute my riew. When I adrised him rather to pay the money from the Treasury and chance the consequences with his Parliament, he said he might have possibly thought of that, if New Plymouth had not betn his own ground, and a place, besicles, whose incessaut begging had long since tired the Ilouse's patience. The 
financial position was this: There was $£ 12,000$ a year interest to provide for. The present legal local rating was exhausted at $£ 5000$. There was practically no income, or at least no surplus over expenses from the harbour. The House had permitted one liberty and another previously for meeting the interest, chiefly, I think, by either selling or borrowing on some of the land endowment of the Harbour; but the House resolved now to end this illegal forestalling of the Harbour's resources. It was expected that the $£ 5000$ of rates, with $£ 1000$ more, scraped up somewhere, would tide over the 1st of November coupon, but that the 1st of May (1889) must be in default, not only from total want of authorised funds, but owing to Parliament having already been prorogued till some weeks after the next coupon was due.

There is a very large land endorment, in the shape, at least, of a rental charge, although not as yet yielding actual income-so large and valuable indeed, that I think everything will be eventually made good. The more is the pity, therefore, that default should meanwhile occur. So scrupulously punctual have the Colonies been heretofore, that not only the Government loans, but eren the municipal and harbour, in the London market, have never been under default in any case whaterer in my recollection for above a quarter of a century, with the sole exception of the city of Hamilton, Upper Canada. But so serious has been the consequence of this temporary mishap to that now large and wealthy place, that its credit, in London 
at least, has never been recorred since. When the city wished to remove the stigma of its stocks continuing much lower than other's in that market, this could be done only ly ordering its Lonilon bankers to buy up and return to it any of the securities still in circulation there.

When I told this to Sir Harry, and asked him if he would still default, he slurugged his shoulders, as a mute declaration that lie could not help himself. Having told me that he had directed the Gorernment agents, the Bank of New Zealand, to tell the bondholders that the May coupon would not be paid, I strongly advised him to telegraph cancelling that order, which would, in fact, have the appearance of cruel indifference, seeing that there might be at least some hope, during the six months' interval, of tiding over the difficulty. "Sufficient unto the day" might be the evil thereof. If the due parment were really impossible, it wonld be enough to let the unfortunate expectants know to that disigreeable effect the mail before.

The supposed redeeming or qualifying point of the 6 per cent. given on the bonds, I liad to tell the worthy Premier, was simply a blunder, and so much money thrown away. The New Zealand harbours generally are in a different position from the ordinary municipalities. The latter are quite free under popular election; the others are rather of government initiation, although they may also be in a special or qualified way elective. If the proposed harbour seems to be insufficient by itself as a security, it is usually supplemented or complemented 
by something else, usually land endowment. And then comes the question - when all this intencled sufficiency happens to prove insufficient, who is to blame, and who to suffer? Obvionsly the Government should have made the harbours their own security, and thus have borrowed the money at 4 instead of 6 per cent. I strongly adrised the Premier to arrange a "conversion" even now. Indeed I had already sketched out a plan, which I sent from Hobart to my old friend Sir William Fitzherbert at Wellington, showing that, if based on a 3 per cent. substitution stock, the Government might still realise a large profit. They might offer a reasonable exchange of popular and readily marketable 3 per cents. for unpopular and unmarketable sixes. Unreasonable holders rould gradually come in by force of the convenience of the exchange. The Government might still receive from the respective Harbour Boards the original interest rate, while the considerable net difference might go to a guarantee fund which could help such weak-kneed brethren as the New Plymouth over an occasional difficult stile. I advised the inclusion of the municipal stocks as well, if they could do so, and, as in Qucensland, prevent these also from coming directly upon the London market, with their almost countless small and ummarketable loans.

I may not go over again the question of issuing in future 3 per cents. instead of 4 per cents. Sir Harry, to do him justice, had not much objection; only the heary discount on the first issues (realising 
a price probably a gond ileal under in per cent.) micht, he thought, canse the project to he disliked by his Parliament. However, as he remarkerl, the sulject was not one of immediate moment, as the Colcony was pledged not to come on the London market again for three years. Thhen I met sir Harry again in Wellington a few days after, we had a discussion on protection, in which we agreed much less than unou the 3 per cents. But some of his remarks, and my replies, have been incorporaterl, along with those of a good many others, ju that rather long "digression" alrearly giren, so that I must not further aggravate my reader in that somewhat dry direction.

\section{Some New Plymouth Resources.}

The defectiveness of the harbour, howerer, dil not malie New Plymoutl and its smroundings any the less charming. The climate was delicious, the scenery rich and beantiful in almost every direction. The place too seemed promising in resonrces. Besides the usual grazing qualities in the profusion of rich grass, there was a large flax trade, made eviclent to us by the number of passing magons or carts, loaded with the prepared Phormium tenax, in bales ready for shipment. I was told, however, that, as in point of tenacity, in spite of its name, it wonld not compare with Russian or Manila hemp, it was not used at Home for rope, but for paper.

The black metallic sand next took our attention. I hope Sir James Hector, whose work, although 
promised me, I have not yet to hand, explains this most curious feature. It lies on the beach in unlimited quantity, and of almost pure iron, being at least 75 per cent. pure. I fear that Britain's cheap and abundant iron prevents even this rich quality from "paying." But adequate scale or improved manipulation may yet succeed, in spite of the local expenses and the remote situation of antipodean New Zealand. Although tried before with failure as result, there was, at the time of our visit, a fresh "hand at the bellows," and some $£ 2000$ of capital was to be risked once more. Better luck to the new hand.

\section{Cook's Strait, and Nelson.}

Quitting New Plymouth about noon of a fine bright, breezy day, we had time to admire several grand rocks close to shore, and speculate on a harbour mainly of nature's founding, which the most conspicuous of these bold rocks suggested, only it was at a cost perhaps of two millions instead of the tenth of that amount already flung away on the tiny patching beside it. We are, soon after, in a straight line for Nelson, at the head of Tasman Bay, on the South Island, whose beauties of climate and scene I had long heard sung by my friend Mr. John Beit, who had resided there a dozen years, although he deemed it a "sleepy hollow" in other respects. But, unless I am greatly mistaken, pretty little Nelson has a future, and not very far off, when the mineral wealth everywhere surrounding her is added to her unrivalled richmess of soil, and when the great 
Midland railway scheme, now progressing, has opened her a way to the Western coast with its gold and its coal, and to the Midlands, and the Eastern coast, with their limitless product of cereals, wool, and frozen meat.

Cook's Strait is very wide here, and we encountered, what is not at all uncommon, a furious storm during the night, one of the incidents of which I recur to further on. But all the more delicious was it when, at dawn, we found ourselves steaming up Tasman Bay, whose sheltered waters, smooth as a mill pond, reflected a panorama of snow-topped mountains, which seemed to us, if not quite so lofty, hardly less variel and beautiful than the Swiss Oberland, or the glorious surrounding of the lake and town of Lucerne, minus perhaps, in the Swiss case, the huge foreground pile of Mont Pilatre.

\section{A Natural Harbour in the act of} Self-construction.

Nelson lay peacefully near the head of the bay, behind a remarkable natural harbour, whose origin and aspect set more than one of us into a train of thought as to how so very convenient a work of nature could have arisen. From a precipitous and still slightly prominent rocky coast of the bay, on its east side, a few miles below Nelson, a natural breakwater had evidently taken its origin, and gone already some miles southwards, ending, howerer, in the sufficiently deep passage still left, and which is now being used as the harbour's entrance. Within 
this natural harbour there was as much in some parts as nine fathoms of depth.

But whence, in this usually quite sheltered bay, came the force necessary to do all this work? Evidently time was needed here, as in so much else of earth's plyysics. The whole process must have been extremely slow. This was shown by the fact, that all the stones of the natural embankment, many of them large, were quite rounded with long water-wearing, as they were chucked onwards by time's gentle hand to make room for the younger brood coming on behind them. I noticed too that, slow as the breakwater's march forward was, it was beyond the pace of the fresh supplies furnished from the cliff, for there was a considerable interval of water between the cliff and where the breakwater showed itself above the wares. This second entrance was not, however, the deeper of the two. But, say a million years hence, when the embanking drift may have passed beyond the entrance now used and right up towards the bay's extremity, Nelson maty have to deepen this other entrance, and, if people are still trading in those adranced times, pass all her grand commerce through that gate.

TVe found Mr. Charles T. Fell waiting for us, a relation of the Premier, who had telegraphed him to be on the outlook. As we walked through the consideralle town, with its two chief streets at right angles, contatining some good banking and insurance huildings and fairly good shops, we met and were duly introduced to various local notalilities, from the Mayor, Mr. T. Sharp, and Judge Broad, of the 
Southern Island Circuit, down to banker's, merchants, lawyers, storekeepers, and other commoner people. Then we drove out a mile to the Atkinsons, lrothers, nephers, dc. of the Premier, and who had intermarried with the Fells, or rice versi, in strings in which I soon lost my way. But this mishay in no degree diminished the pleasint family picture around us as we chatted and sipped tea in a rural but elegant drawing-1'oom, graced outside and in with countless flowers. As we returned to our boat in the afternoon, we hat time to notice the very bellicose character of the streets of Nelson, named as they all were in homour of the most prominent admirals and captains who served under the greatest of all naval heroes.

\section{The Natives and their Reserves of Land.}

We were now off for Picton, a small town at the head of another of New Zealand's magnificent natural harbours. Te had daylight only to pass us through the narrows of D' Crrille Island channel. The island is reserved as native territory for some of the few remaining natives of the South Island; but they will probably soon sell it, as it is reputed full of minerals, of which they are not likely to make any use. The reserves which the Goverument have allotted to the natives, or sanctioned their retaining, may be sold or leased by them at will, but not to the extent of leaving themselves destitute. I think they must keep at least fifty acres per head. Some of them, mostly of the North Island, are very rich, orwing to their sales or leases. 


\section{A Notable New Zealand Colonist.}

Regarding D'Urville Island and its minerals, as well as the mauy other mineral lands hereabout, I got much practical information from a fellow-passenger, one of the members of the Assembly, Mr. John Ross, a brother Scot of Millothian descent, but so extremely rough a diamond, that more than one friend on loard hinted to me that a certain terminal to that adjective, which I shall not be so rude as to repeat, would not badly become him. But he had an amazing fund of practical remark, which made him, whether rough or otherwise, most welcome to me. He confirmed other experiences about the difficulty of getting London capital to buy or advance on the New Zealand mines. He had offered repeatedly to pay all costs if London capitalists would ouly send out competent mining examiners to see and report upon the New Zealand mineral wealth; but latterly he had abandoned all hope, under the impression that London capitalists were unfathomable beings.

I endearoured to explain to lim that in any negotiations, under present business modes, people out here did not come in direct contact with the capitalists, but only with go-betweens, who were bent upon the immediate, with as much bonus, conscionable or unconscionable in amount, as they could get out of anything in particular for themselves. Once, however, some year's ago, as he told me, he did induce a London "syndicate" to send out a competent scientific examiner, who saw, with favour- 
able eye, what Ross pointed out, but who, by some unaccountalle mistake, after returning home, made the report under name of some other mine, also offering in another direction. How the thing ended, how the shareholders, on whom the wrong mine, possibly not through mere accident, was to be "lauded" fared, he never heard. But from that time he gare up London in despair. "And now," added he, "the whole mineral country hereabout is in waiting for meąns to derelop it, and we can't, on any endurable terms, get these means. But our own means being so small, besides being otherwise engaged, our lrogress will languish unless the outside help come."

Amongst many interesting things Ross told me were some of his early incidents with the natives before and during the war time. Although people who speak so much, and so incessantly, as my new friend, are not inapt, at times, to include, by mistake, things that never happened, yet in the consistency of his details, and in other respects, I was rather farourally impressed by him. Approaching three score, as he now was, and of somewhat stout build, he was still a most muscular fellow, albeit just a trifle under average height; but 25 to 30 years ago he must have been a formidable antagonist, and still more so if of any practised slill of muscle, as I believe he was. He lived in Taranali at this time, close to the considerable tribe which was there chiefly at the bottom of the war. He was a fearless fellow, who bolbed in and out amongst these natives, day or night, as one of themselves. On one occasion, after 
spending the night in the Pah, he was soreless as to forget his knife. his indispensable companion. After perhaps an hour or two he went back to claim it. The first native he met was a young moman of the chief"s kitchen. and he kuew that if the knife were not at once forthcoming, which he did not in the least expect, he would require some tacties to get at its whereabouts. The following conversation ensued :-

He. "That knife?"

She. "Not know any Pakihah knife."

He. "That no good. See here. You know Palihah never tell secret. Chief got my knife?"

She then signified ummistakably that he had. And riow Mr. Chief had to be dealt with. A formidalile dealing it was too, for he was a huge, muscular fellow, weighing orer twenty stone. He lad a younger brother as heary as himself, the two being conspicuous in the whole tribe; but the yonnger was not so muscular as the chief. Ross, luesides all his pluck and his more ready and adroit morements, hat no idea of being done out of his knife. Besides, he knew so well the riews and rules of Maori life, that in any fight between him and the chief. there would be perfect fairness on the part of the trilie, although quite ninety in number all around him; he knew that, in fact, they would enjoy any fight too much, if things did come to that, to interfere unfairly with it.

Waiting till the chief came out, and had walked in all apparent corliality towarls hin, Ross responded by walking purposely past him without the 
very slighte-t recognition. This was the greatent posible affront. and the chief iustantly that romm to know the reason. "I never salute a thief," replied the undaunted Ross.

This nuant mattle. In a moment, ere Poss comld arrange himselt, the weighty eneny was upon him. liftiug him up. and giving him a heary grounder on his back. Unhurt, he hat sprung "ry again at nuce to his turt. lut only to be served its betore. But the thind tine he was hoth more quich and more cantious, and posibly the other's mucher were for the umment it tritle the worse for wear after his double exertion. As he came booming along the thiml tine, Ross, who had edged just ont of his path. cinght him such a stunuer with his fint on the nose. that the bloud spirted out in a stream that conld unt for some time be sippresed. Finally the chief ruale the sign, with his blool-dripping fingers. that he gave in.

By Mavri law this chief was thus Pus's slave for lite. When the war hroke ont here shortly after, Ross werst to the commanuler, and offerel to hring in this man " by the nove." if his dushing movement were backed by cortain dispnsitious, which would leal to the simultaneous capture of the rhole trihe. He was not only not listenerl to. hnt onderenl to mind his orr business and be off. The commandant, he said, threatered that if he did unt hold his clatter of a tongue and be off. he would lave him imprisoned. I fear that Ross had only to thank limsiff, for a ruore rude and ungainly specimen of an alvocate for even the wisest counsel I never mat 
with. But as I was seeking information, and as he, by the self-erident consistency of what he said, was reliably giving me what I sought, I, for my part, most willingly conceded to him most tolerant and appreciative behaviour.

Mr. Brown, another member of the same Assembly, and fellow-passenger also, was one more of my chief informants. He was going on with us to MTelbourne, to stay there in the same hotel, so that we had much talk together. He had been more fortunate than Ross and others in getting out his company, a gold one, I think, for every one seemed to have some company or other to look after. After much persuasion; scientific mining experts had been sent out, who, reporting farourably, the concern was "floated," and promised now to do fairly well. He was a strong protectionist, as indeed, for so I have to admit, were most of the people whom I met with in Australasia ; but, as I have put him "passim" in my "digression" aforesaid, I shall not again stir up that mud here.

\section{Picton's fine Harbour and Oysters.}

We reached Picton late at night, but with moonlight sufficient to show us its grand coast line, with its narrow but deep waters, like another Loch Long on the Scotch Clyde. We landed and stepped about in little street-deserted Picton, and then hied us to an oyster-shop, still open in expectation of our visit. Picton is famons for fine oysters, but we found that we had come at what may be called an extra "close time," for the practice here is not only to have the 
regular yearly close time, but every few years a longer interval of rest, to restore the crop more effectually. What we now got here were not Picton, but imported Auckland, oysters. We did them justice, however, and took still more of them on board for friends.

Picton's situation was thought so much of, that at first it was spoken of as a rival capital, preferable even to Wellington. But North Island influences, then in the ascendant, carried the day for the latter. The screw turned once more, and we were off to Wellington, where we arrived in the early morning, too early, unfortunately, to see distinctly the entrance to the noble harbour. We were recommended to the Empire Hotel, and made our way accordingly, to find a very comfortable, but not, otherwise, very pretentious establishment, situated in what seemed the chief business or shopping street. Here, with our limited time, we at once gathered ourselves up for work. 


\section{SECTION XVII.}

WELLINGTON, THE OFFICIAL CAPITAL OF NEW

ZEALAND.

Wellisgros goes back to the very earliest of New Zealand regular settlement, Gibbon Wakefield having first opened the colonising field in 1839. My old friend, Sir $W^{\top}$ m. Fitzherbert, was amongst the earliest, but another friend, of more recent acquaintance, MIr. John Plimmer, Father of the Wellington and Manawatu Railway, who arrived in 1841, was rather before him, for he was ready, as he told me, to do some house-building work for Sir William on his later arrival. Even such slight incidents of early Wellington are already locally interesting, in view of the considerable progress to-day of the New Zealand capital. The city's decidedly most striking feature is its great palaces of wood. The Government Offices are boastingly spoken of as the greatest wooden edifice in the world. The Parliament House and the Government House are also of wood, and, when I called for the Premier at his official residence, I found that it too was of rood. A handsome large stone or brick-plastered Post Office, just opposite our steamer's wharf, had lately been burnt down. There were, however, some good bank and insurance buildings, which had already emerged from the wooden stage, besides some solid and large stores of the Turnbulls and other leading merchants. 
There was ample wharf accommodation, and a splendidly spacious and deep hartour, in which, as I estimated, might be easily packed erery ship of war of the world. It was surrounded to east and north by fine mountain scenery. The city had mostly a terraced appearance, and with pleasant effect; but. considering its size, it struck me as the least pretentious of all the New Zealand towns. It was, for instance, deciledly short, in town elegancies, even of Invercargill, which was barely half its size; while Dunedin, and also Christchurch, seemed quite beyond comparison.

\section{A Visit to Sir W. Fitzherbert.}

One of our first duties was to drive out to the Lower Mutt River, to pay a visit to Sir Wrm. Fitzherbert, whose acquaintance I had made in London above twenty years before, when on his mission to carry out the earliest " cousolidation of New Zealand securities," and when I undertook to initiate lim into some of the market "laws" described in the Hobart Section of this tour. I had also met him a little over two years ago, when he was in London for the great and successful occasions of the Colonial Exlibition, and the still more significant Colonial Conference, under the Secretary for the Colonies, Sir Henry Holland, now Lord Kuntsford. He was then wonderfully active for a man who had entered his serenty-serenth year. But this time I noticed a marked change, and he pathetically alluded to its chief cause as, pointing to the portrait of his wife, who had died the year before. he remarkerl that with 
that life went out the bright light of lis own. But a joyous surrounding of children and grandchildren left still something for the veteran to care for. We saw them all assembled at home, or at the church the following Sunday. Sir William continues his Presidency of the Upper House. Long practice not seldom makes duties easy and even pleasant to people who, as regards work generally, have closed their accounts. We discussed old times, and these altered circumstances which would entitle New Zealand, on the next occasion of public borrowing, say three years hence, to rise to the dignity of a 3 per cent. loan issue.

\section{Maori Town Life, and Native Village of Petoné.}

On the way to the Lower Hutt, we passed through the considerable village of Petoné-properly Peto-oné, in native tongue, signifying "the end of the beach." It is about four miles from town, while the Hutt is one to two more. John Bull "slumps" this word Petoné, as he does so many others, for brevity's sake. But the natives, like good "Turanians," as Professor Muller explains, never slump their words or roots. A good many natives live in Petoné, having small cottages and gardens like the colonists. There are also many of our own working men, owners of their own house, and in most comfortable circumstances, with $8 s$. to $10 s$. a day of wages, who go in and out by the cheap trains. The New Zealand native is still so considerable an element in the rail system, that notices are put up in Maori as well as English. We saw also a notice in Chinese, 
as there are now generally over Australasia a goonl sprinkling of Chinamen. Here is a sample of Mami railway literature: "Kana e kai paipa ki konei," literally translaterl, "No food of the pipe in this place," and equivalent to the English "Smoking strictly prolibited," an intimation which was printed alongside.

Let us consider here how alistract ideas are used by the advanced race, and only concrete or substantive ideas by the other. The Maori's language, at all events when lie was as yet uninraded by the higher id lear, would not have had words at all equiralent to the above English notice. Our very young children resemble the natives in that respect. They do not understand abstract spealing. At a Sunday-school class I know of in Kensington, the pious mistress asked her little troop the meaning of the words "Great peace have they who know Thy law"; but to her sad disappointment every successive small head gave a most negative sign. One, howerer, was observed with bright face to be waiting her turn, and she was out in a moment with the anstrer; "Yes, yes," she sail, "elepliants, cows, horses." Upon some explanation following this unexpected answer, it appeared that the little maiden had mistaken one of the words of the sentence, for it had reached her ears in this fashion: "Great beasts have they who know Thy law."

\section{A Working Class Conference.}

Observing a group of Wellington workmen, who were resting after their dinner, I marle up to them 
to have a discussion anent their class, and its condition and prospects, in the New Zealand capital. They were no way loth, so at it we went.

How did they stand, as to most things, compared with prices and wages at Home?

Well, better in some; worse in others. House rent and clothes dearer, the former a good deal. Food, again, mostly much cheaper, especially butcher meat, which they seemed to think absurdly cheap. They said they used to get it, and even now, although rising of late, could get it still, at a penny a pound. A working man, they remarked, would have a small leg of mutton or lamb to dimner, and chuck the unconsumed half of it to the dog.

Then the rates of wages were, on average, $8 s$. a day for an ordinary labourer, and 10s. for a skillerl labourer.

T'o my remark that the ordinary labourer secmed comparatively highly paicl, they said that he was usually more handy to his employer than the other, who would be rather stiff to turn his hand to other than his own proper work. Then, as to the security for continuous employment, they said that such was fairly sure in Wellington, or at least so much surer than in the country, that there was a habit at times of drifting into the capital, and taking awaty some of the work from the residents. Eight hours was the usual or universal time of work.

The working men are nunch in the halit of handing together amongst themselves to take up contracts, and they are so fond of this mode, that, in competing with the employing clisses, they will, as the Premier 
and others told me, eut down a contract till it will yield them only half of what they would have made by working at wages. This is an ambition not to le gainsaid. It reminded me of the experiences of the Victorian Gold Commission of 185t-5, when the working diggers used to exhort their fellows rather to take up mines on their own account as a partnership of principals, with $10 \%$ a day as result, than submit to be paid 20s. a day by a capitalist employer.

\section{The great new Meat-freezing Trade.}

Retuming from the drive to our friends the Fitzherberts, we called, as directed, at The Gear Company's works in Petoné, to inspect the meatfreezing system, so recently introduced into New Zealand, and already so vast and promising a business there. Curious considerations arise upon this business, suggestive, in one direction, of the value of a general education in the elements of physical science. The preservation of fresh meat by cold was begun as a business in Australia nearly fifty year's ago, but the only thing thought of then, and for long after, was to do it by means of ice. This was enormously expensive, by reason of the quantity of ice required, while, if from any unforeseen canse the ice gare out, the entire cargo had to be at once thrown into the sea. More than one cargo was served in this way, to the ruin of its owner.

All these long years science knew perfectly of the most simple process by which all this danger, and nearly the whole of this expense, might have been 
avoided. But those who knew the science were not brought into practical contact with the need, while those who were in such contact did not know science. For instance, I was quite familiar, through attending Dr. Hope, in my schooling dars, at the Edinburgh University, with the cxperiment showing that air when compressed became rery hot; that when released again it returned to its first temperature; that inferentially, therefore, if the compressed hot air were first conled and then freel, there would be more or less intense cold, accorling to scale of opcration. But it never occurred to me, nor as I presume to hunclreds of other's not in the meat trade, to apply practically this science. But the science happily is now applied, and with all tlie results to be desired. 'The air required is taken at large from the surrounding atmospliere; when heated by condunsation it is cooled by the sea, and it is then expanded into a great air-tight chamber in the ship, filled with carcases, which can thus be liept to any low temperature necessary.

The Gear Company carries on a considerible work, although exceded in scale by others in ('iristchurch and Dunedin, and ly further rivalry in Napier, and perhaps other places; for this meat question, with a market of thirty-fire millions of Home population, is of surpassing extent and inpurtance. 'Tlhe C'ompany can "slaughter" as many as 1,500 sheep and 50 to (i) cattle in one day, although they cannot, as yet, effect the "freczing "for more than about the half of that fuantity. The diy we lookel in, they were just finishing 700 slieep and is caltle. We pre- 
ferred not to witness the last end of three poor remaining sheep. There was a small steamer in waiting at a pier to transfer the carcasses, in a frozen state, to the ressel engaged to take them to their Home market. The Company has gradually taken up, all branches of this business, and we saw the pelts and skin wool dealt with, the lones prepared for various utilisation, and a great facture of tins, which were being painted and labelled for contents of tong'ues, liluneys, tails, or other choice parts.

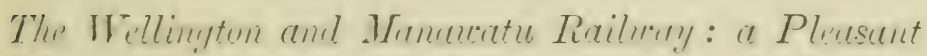 Excursion.}

One of the worls I wished most to see here wals the Wellington and Manawatu Railway, which my whl frients the Scrimgeours, of the London Stock Exchange, had favourably introduced to my attention on the first entry of its securities into the London market. I had always therefore held, in the way of Lusiness, a large amount of its bonded securities, besides something of its share stock. I male the ncquaintance of the Directors, who indeed already lnew me well by name as a large bondholder, and they did me the honour to invite my party, together with a friend or two, to a special trip along the entire line. We had the most favourable of weather, and altogether a most enjoyable trip. Mr. Wallace, the able aud well-informed manager of the line, who, with several others, Directors, including its father, Mr. Plimmer, accompanied us, was a perfect encyclol'orlia upon his sulject. He wats also master of the Manri language. What appreciably increased our 
enjoyment was the sort of "lappy family" look of the whole concern. They had entered upon a great undertaking, as to which many outside had at first shaken their heads; but their reward was already in course of sure development.

The line is 84 miles in length, in a northerly direction from Wellington to Longburn, about four miles short of the rising town of Palmerston, where several railways connect. It was completed in Norember 1886, having been begun in 18s1. It traverses a country as yet almost entirely unsettled, but of the most fertile and promising character, besides being the direct road to important places further on. It has cost, including rolling stock and stations, $£ 800,000$. There was some difficulty in establishing the Company, and raising its capital, as it was feared that a line through a reputed poor or too heavily timbered soil would not prove remunerative. The Government had begm the line, but, chiefly on this consideration, discontimued it.

Mr. Plimmer, the "father of the line," took up its halting cause. He ascertained that the interior lands it would traverse were extremely fertile. He and his supporters agreed with the Government to carry on and complete the line. The Government, in fact, transferred its beginnings to them, giving freely over to them such little as had been done already, together with a grant of 210,000 acres of land along the line's course.

We started on 15th September, on a beautiful lright spring day, at 9 A.M., returning at 5 P.M., after ahout an hour spent at the northern extremity. 
We were honoured by a special train strpplied for the occasion. The excursion was delightful from the number of oljects of novelty and interest, including the dense tangles of indigenous forest spread over many miles, and the considerable number of aloriginal natives, who were congregated in little villages along the railway line.

The line's main liopes, of course, were upon the future. The through traftic, however, yielded a fair return, which now paid, besides expenses, almost the large dehenture interest, and was steadily, even rapidiy, increasing towards a grood dividend on the ordinary stock. Townships were dotted over the line, but, with scarce any exception, there was not yet a house in such townships excepting that of the station master. Nerertheless, these townships, where their allotments had been sold, had brought, in most cases, the large sums of $£ 200$ to $£ 300$ an acre, while the lands along or near the line had sold for 40.. to $1 ; 5.5$ an acre. These latter were mostly extremely fertile, and were alrealy largely overgrown with rich grass, which, after being but partially planted only a year or two before, had suon overspread wherever there was a clearing of the native timber or shrubs. One pretty spot, a little sandy bay, with an inlet of the sea, into which a small stream emptied itself, quite charmed us. It was called Porirua Ilarbour, on which was Plimmerton, so called after, as I have described him, the line's father. Its allotments liad been lately sold at the lighthest prices - as high as at the rate of from $\$ 300$ to f 400 an acre, as the prospect was that, 
being only sixteen miles from Wellington, it would in time be a holiday place of attraction for the rich Wellingtonians.

At some of the stations we met small parties of the natives. At Otaki in particular, about half way over the line, where we stopped ten minutes, we found a party of about a dozen, including six or seven womeu. They were chiefly old people, but there was a nice-like young boy, with a ruddy brown cheek, not nuch distinguishable from an English lad, and there was also a pleasant-looking, if not absolutely pretty, young woman of about twenty-five. We drew out some amusing and interesting characteristics, chiefly from the women. The old women were mostly tattooed on and under the lower lip, but the young. one was not. I intimated my decided preference of the latter, which caused them much amuscment, expressed in loud bursts of laughter. When the girl took me ul, as she must lare done, as rather admiring her as compared at least with the others, the expression of modesty on her face, as she tumed it away, was very pleasing. Next came an amusing pass. We wanted to see how they kissed. This we had been told was very comical, as it ended by rubbing noses togrether. Apparently, however, nothing would induce them to do it. 'They langhed ontright in the ligghest good nature, but would not kiss it le Afuri. At last I promised a shilling if they would do it, and after a little more coaxing and continued laughter it was done. They are usually very careful of money and very licen to make it. When I promised the shilling, I 
happened to be looking at the ekler female and not at my farourite, so she understool the barmain to have heen made with her, and the moment the kissing was over she held out her hand for the shilling. Hat I been mischievous. and affected to milke it all a joke, and pretenterl to refuse the money, there would hare been a row of some lind. Howerer, I gare both of them a shilling. to their entire satisfuction.

The native chiefs are often large landed proprietors, and the line ran either through or nuar to parts of their reserves. One chief hat granted. free to the company, the lands needed for the line, becanse, as the silit, they deserved such support, from their courage in semding a line through such an unpeopled country. They are not prevented from reselling to colonists the-e assigned land, and some have done so, hut they may not thins sell their whole estate. They cannot, as I lave alrealy hinted, sell when they have not more left than fifty acres to each person. It is de-irable, gencrally speaking, that they should sell, as very large tracts are otherwi-c left almost waste, to the detriment of the Culony. They have been liberally dealt with, if we consider that these land endowments have acquired all their molern value from our colonisation. Of course, the altemative riew is that we have deprived the matives of the whole country, and can hatrily he called too generous in giving them back a minute fraction of the whole. The natives themselves, however, recognise our linduess. Doubtlens they know well enongh that they themselyes, when the mose 
powerful, as invaders, would have simply extirpated the invaded, and taken the whole land without a trace of scruple.

Although the natives don't like regular daily work, such as that of our civilisation, yet they are not wholly ille, especially where there is a sure and immediate money result. One of the labours which, as having that prompt result, suits them best, is entting wood for the supply of the railway engine fires. We noticed this wood, cut in suitable pieces, stacked up along the line, where it passed through the native territory. Sometimes it would be piled on both sides, and one continuous line of it which we passed was quite a mile long. The colonists do a little in this way too, but it is chiefly the work of natives. The stacking was 3 to 4 feet high, and of about equal width, making a low broad wall on the line's edge, ready to be used when wanted. Trollies sally out to gather the fuel, and the chief is duly credited with his price. An almost incredible quantity is used in substitution for coal. Standing upon the engine to witness this consumption between two stations, we saw the solid billets go in by the dozen and disappear in the furnace in a very few minutes. Mr. Wallace's estimate, as between wood and coal cost, scemed decidedly for the former, as the respective prices then went; but, if approach to express speed were wanted, they must fill back upon the solid coal.

The seenery was at times very beautiful, with oceasional views of Cook's Straits, of the opposite coast uf the Southerw Island, of the snow-caplyed peals of 
the interior ranges northwards, 4000 to 5000 feet in height, and, when quite clear atmospherically, of grand Mount Egmont to the N.W., upwards of 8300 feet in height, rising like a pyramidal white cloud on the far horizon, when as far as 120 miles distant. The indigenous forest was at times in such a tangle of impervious regetation, as to remind me of the description of the dense vegetation, penetrated only by aid of the hatchet, by our troops in their mareh upon Cuomassie from the African Guinca Coast. The fine lofty mountains, mostly covered with evergreen timber, and the pretty winding rivulets that issued from their valleys, recalled, to some extent, our Scotch Irighlinds, with the ceascless gurgle of ruming water. On the liills was chiefly the white pine, a poor tree of neither size nor beauty. The flats and rich-soil marshes had much of the New Zealand flax, which is now an article of large trade, but, having a fibre less strong than Russian liemp' and other like material, is used, as I have already said, for paper instead of roping. I formed a high opinion of the prospects of this line, and expect that ten years, if not sooner, will see it a succession of busy towns and commerce. 


\section{SECTION XVIII.}

\section{WELLIYGTON HARBOUR TO LYTTELTON HARBOUR.}

With reluctance we quitted Wellington, after our far too brief stay. It seemed to us a most pleasant abole. More than once I found myself standing: musing, as I watched the people, especially the working men, to try if I could make out that they at all appreciated, or even troubled themselves to think about, their giorious surroundings as to climate and scenery. When I touched, tenderly, on the point with my working-class friends before alluded to, the hide was evidently too thick for refinement of that non-practical kind. "Oh yes, climate good enough, and that sort of thing." "Better than at home?" "Olı, yes, grood enough." They reminded me of Puncli's coming Reign of Science, which, depicted prior to Mr. Forster's general Education Act of 1870 , had left the working man in stutu yuo. So he malies his own casy swing through the jaw-breakers of science : "Bill, hand us up them Zulphuds."

But whether the other classes had much more appreciation of the almost al fresen life which their delectable climate allowed them to enjoy may posibly be a question. Perlapes a rare crood luck showed us Trellington rather better than arerage, for it is reputed to be rather rainy and windy. Perhirps also we were at just the nust chamming part of the yeall, when the rich life of spring was hloming every- 
where. An American risitor, who had preceded ni: on leing told there had been, or been supposen to lie, had times in Wellington, and elsewhere in New Zealand, is stated to have held up his hands in amazement, exclaiming, "Bad times in a climate like this! Impossible!"

\section{Fine Coasting Steamers: the "Wairarapa."}

We were now to take boat from Wellingron to Lyttleton by the fine steamer " Wairarapa," one of the finest and fistest of the Cnion Company's large fleet. which hat the day before cone in from Anckland. We should have gone thence by her had we not decided for the west coast route, at once the shortent, and, as we thought, the best worth seeing. But, to have fulfilled its repute as the shortest, we should lave got out of our little "Penguin" steamer, and taken the rail from New Plymouth to Tellington. But this we were prevented from doing: lecause, although the line is there all male and reatly, it is as yet kept running with only a bi-weekly or triweekly train. I fear I must almit that this is one, and far perhaps from the only one. instance of tuoanticipatory railway building; for here, at meat cost, was a long piece of railway, which was all lut unusable for want as yet of people and comnerce.

The " Tairarapa," a Maori name of course, and in good taste such, was really a five boat, in well-dramn lines of iron, with a well got-rp interior, including the great comfort of the electric light, which was "laid on" with all the facilities of gas, excepting. that the initiatory match was dispensed with, and 
the heat and air-vitiation of the gas equally disposed of. The vessel was 1700 tons - no size nowadays, indeed, but sufficient for her orn business on the intercolonial line between Auckland and Melbourne, viî Dunedin and "the Bluff." She went alternately, viâ Hobart, and to Melbourne direct. Our turn was this time ria Hobart, a delay which, however, did not disturb us, as I was still in plenty of time, for my only anxiety as to time, namely, an Old Colonist farewell dimner, with which, fixed for the 1st Octoher, my distingmished friend, Mr. Francis Henty, Chairman of the O.C. Association, was to honour me before final departure for Home ten days afterwards.

The Union line was generally well supported by pessengers and goods traffic. I heard at times some sighing for an opposition that might lead to a more accommodating treatment, as well as lower rates for the struggling New Zealand trade, as on nearly every hand the turn of markets had been against the Colony, in low prices of wool and cereals, and the difficulties of establishing in London the new frozen-meat trade. The vessel was quite full of cabin passengers this time, besides a full complement in the steernge, consisting mainly of the working and smaller trading classes, who, as I afterwards describe, were trooping out of New Zealand, on the recent comparative cessation of railway-making. Some young ladis, accompanied by their parents, were going to the Christchurch schools and colleges, which, on their Anglican foundation, and otherwise, are preferred in adjacent parts of the Colony. Some 
of these were fine muscular fellows, likely some dily to leave their mark in football or cricket.

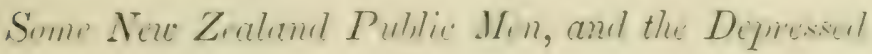

Times.

We had also on board some distinguished colonists; chiefly, atmongst others, Sir Willian Fox, the reterim ex-premier, who, although serenty-six, was upon m active propagandist temperance mission, and was to address, on that sulject, a pullic meeting on lis arrival at Christchurch. I easily introducel myself to Sir William, as we were each familiar witl the other's name. But we also recalled that we had met at the Bank of New Zealand in London a good many years hefore, when both were a trifle less aged than now. He spoke like a man still vigorous for any question. I did not hear his lecture on the night of our arrival, as I was too much otherwise engaged.

Another important fellow-passenger was the IIon. Mr. Fergus, New Zealand Alinister of Defence, mpon whom I opened in the way of question and answer, after he had sufficiently recorered from a preliminary purgatory, or at least purging of its own kind, to which he was liable at sea. There was also Mr. Chapman, son of the late Julge Chapman, an whl friend of mine, and both of these New Zealanter's were hound for the Melbourne Exhibition. Julge Broad, who had accompanied us from Nelson to Wellington, but had gone off thence at once to Christchurch, on his South Island Cirenit, afterwards rejoined us at Oamaru, en reute for Dunedin. Discoursing with him on the late New Zealand depres- 
sion, he confirmed my orn view that the bottom of the depression liad been reached about the end of last year, because, as he significantly remarked, his list then was blucked with bankruptcy cases, whereas this time these had virtually ceased.

Mr. Fergus interested me upon his own subject of defence. Evidently colonists do not like, or rather perhaps cannot, with their scarce and dear labour, afford to like, the professional soldier. After a naval force, which must be the most immediate and pressing colonial aim, the artillery comes for first consideration as a land force, as the dread for a Colony is not so much a land fight of soldiery, as at hostile ironclad that is to bombard and burn the colonial towns and property, and that camnot be repelled except by good artillery. New Zealand, after having had a thousand regular artillerymon, is now down to only some hundreds. I raised the question of an old idea of mine that every colonial youth should go through military drill, unt for a profession, but as part of education while at school, and subsequently of jurenile recreation, without necessitating cven an hour's economic sacrifice. The step in morale also, apart from the other or defence question, must not be overlooked. I thought that a Colony thus defensively equipperl, and at no great cost to itself, might be held to have done fairly her proportion for the Empire's defence-I mean the military part of the defence; the naval part is now being specially arranged for by a por reta contribution. Mr. Fergus agreed with the idea generally, and said that it was already, to some extent, being realised. 


\section{$(193)$}

\section{SECTION XIX.}

LYTTELTON HARBOCR, LYTTELTON, AND CIRISTCHCRCH.

A BRight morning damned upon us as we approached Bank's Peninsula and Lyttelton Harbour. The Peninsula is a large area of mountainous and fine scenery, forming, for the most part of its area, the very garden of the earth for a variety of products. On the south side, within one more of New Zealand's remarkable natural harbours, is Akaroa, the settlement formed by the first French colonisers, nearly fifty years ago, in the famous race of the two countries for the possession of this grand New Zealand.

Akaroa has not indeed achiered greatness as a town, whether from the quiet, uncommercial disposition of its people, or from having been shunted aside by the rise and prosperity of its rival Lyttelton, the port of Christchurch, the local capital. Akaroa has but 1200 of population to Lyttelton's 4000. But the lesser French nest has had a fairly happy time.

It has been invaded often from outside in that way that brings back to us the famous "Rape of the Sabines," only that the repeated invasions here, while they were those of love, were wholly without violence. Little Catholic Akaroa gets on well with her Protestant surroundings. She finds English Catholics around her as well. Her population gets 
mixed, perhaps to the improvement of the new race that results. She has already ceased to speak French, excepting in a very few families. The Queen will not be long of having Akaroa as much her own, if indeed it is not so already, as the Lyttelton sister a few miles to the north.

Lyttelton stands at the head of another noble natural harbour. It is prettily scattered over the steep slope of the coast range of hills, which culminates in an elevation of 2000 feet. The liarloour, however, has needed some artificial perfect. ing to bring it to its present suitable condition. The slimy shallow at the head of the fine mountainous natural inlet las been dredged to a sufficient depth, even at low water, for the large steamers, up to 4000 tons, which now come to the port, as well as for the other shipping engaged in the great trade of the Canterbury district in Christchurch. A long. and completely sheltering breakwater has also been constructed. As we backed our speed after entering, the screw's motion stirred up the slimy bottom, and immediately the previously clear water was deeply fouled all around. Several large steamers and some smaller craft lay around us. But the bustle of the high shipping time was not yet come round, when all the cereals, the wool, the frozen sheep and bullocks of this rich agricultural and pastoral country come tumbling in by millions in value, for the use of the other kind of millions of the mother country.

A railway pierces the coast range, by means of a tunnel two miles in length, a piece of early enter- 
prise and engineering which does credit to the place. Christchurch, reached by this railway, is seven miles off, and trains go to and fro every liour or two. About twenty-five minutes hrought us easily to the capital.

That variety of feature which we had found in each place successively visited, each with its own attractions, characterised Christchurch as fully as any other. Quitting the coast range, we entered a vast plain, so perfectly level to all appearance as to give the effect of a great ocean with its pretty fringe, in your near neighbourhood, of many rarieties of trees, and shrubs, and gardens, forming the suburban surroundings of the town. There are perhaps as much as 4000 to 5000 square miles of this plain, extending far north and still further south of the Christchurch latitude, with a soil mostly of the richest character, and covered with farms, and sheep and cattle pasturages. In the far distance beyond, fifty to seventy miles westrards, rose one of the interior mountain ranges, 4000 to 5000 feet in elevation, and still covered, more than half down from the summit, with snow. Beyond this range, and above a hundred miles further west, is the higher range which culminates in Mount Cook, an elevation of about 12,300 feet.

\section{Christchurch, and its Remarkable Water Suppily.}

Christchurch, with a population, including suburbs, of 35,000 , covers a most pretentious quantity of ground. Her grand wide streets, of mathematical 
straightness and miles in length, tell us what are the expectations of the ambitious colonists with regard to the future of the central capital of New Zealand's Southern or greater Island. Many open spaces within and around the city give it great adrantages, alike in a sanitary and a scenic sense. Te wandered through botanic gardens, reserves for schools, colleges, and museums, and other purposes, in most cases tastefully planted with trees and shrubs, both indigenous and imported. A clear and copious stream, named, under English classic reminiscences, the Avon, with banks lined with weeping willows, now in the freshest foliage, runs, with many windings, through town and suburbs. This pretty Avon takes its rise in those snow-clad hills to the westward, but it is largely reinforced, in its downward course, from perennial springs only a few miles inland from Christchurch. And, seeing that the city is otherwise supplied, all this fine stream may be said to be wasted and lost in the sea.

Such was my feeling as I stood upon the bridge in the public gardens, looking down into the pure cool swift-running stream, where trout, eighteen inches in length, sported about in numbers beneath. But there was no occasion to bemoan the loss of so much fine fresh water, when Christchurch has other and even better supplies to fall back upon.

This water supply is one of the curiosities of the place. It is entirely from "Artesian" resources. Every house has its own Artesian well, and if there is a large or wealthy household, or an institution, it has more than one well. The water 
is tapped at depths varying up to a hundred feet, and is always there, and of the purest and best. In the lower levels towards the sea-for the great plain, although apparently, is not actually quite horizontal, but rising slightly inwards-the water spouts up several feet above the ground, as we saw in a public fountain in the central square of the town. In other places it comes short loy from five to twenty feet; but by deeper sinking, at a trifle more cost, even in those higher parts the water may reach the ground level. Our friend and guide, Mr. Joseph Cooke, manager of The New Zealand Loan and Mercantile Agency Company, in taking us to his pleasant residence three miles from town, described to us the water arrangement, which was indeed the most curious and interesting feature of the place. The ground being 40 feet highter than the town level, the water is short of the surface by some yards, but by help of a small windmill apparatus, working with every breath of passing air, he not only overcomes this interval, but raises the water into elevated tankis for the supply of the two floors of the honse; and so sufficient is this small power in its almost incessaut night and day working, that he has not seldom to call a halt, and give the faithful machine a wellearned rest. The cost of these wells is surprisingly small, as low in some cases as $f 4$, but more usually about twice that amount, or eren $£ 10$ to $£ 20$, when saving of expense is not the chief object.

There is a considerable display of good substantial and even elegant buildings in Christchurch. The public edifices, as the Post and Telegraph Oflices, are 
hardly equal to those of the banks and other companies. There are several hotels, very comfortable and of fairly good aspect. We went to an old one, Warner's, still mostly of wood. But Christchurch generally, the central and business part at least, has largely emerged from wood, and contrasts strongly in this respect with Wellington, New Zealand's official capital.

\section{The Late Earthquake.}

On 1st September, 18s8, at early morn, before daylight, Christchurch and a wide area around it were visited by an earthquake. Looking at the rast lerel of the country, as if undisturbed from below in all previous time, one wondered what an earthquake had to do there, of all places. But it had in its way an alarming force, and at once sent hundreds, perhaps thousands, out of their warm beds into the sharp air of an early spring morning. When day dawned upon the disturbed citizens, it was found that the top of the spire of the Anglican Cathedral had been shaken off and lay in fragments below. T'wenty-six fect to the culminating steeple-head, whatever that was, had come down. The part thus displaced had consisted of a rather top-heavy structure, made so for some reason or other, which had evidently excluded the consideration of earthquakes. This part alone was affected. The rest of the building, large, handsome, and, as I should architecturally describe it, of the cottage style, was to all appearance uninjured. Nor 
was there any damage elsewhere in the town worth speaking about. One concludes, therefore, that the force took the direction of a lateral shaking, and not in any degree of a vertical or upraising motion.

The extreme and Holland-like flatness of the comtry was relieved, first, by the coast range through which we had just passed in the railway tumel, and again by the grand rista of the snowclad range that terminated the plains on the western interior. The many parks and gardens aronnd the city added further variety to this effect, and greatly redeemed the scene from the monotonous effect which the vast level must otherwise have had. We more fully realised this monotony as we travelled further south, into parts where the redeeming varieties ceased.

In one quarter by themselves, and prettily varied ly ample reserves of grass, and shrubs, and trees, are Christchurcli's educational institutionsschools, college, and a museum well and rarionsly stored with natural history. The town is famous for this latter institution, which we duly visited. The chamber of the great moa, with his congeners, the lesser moas, the emu, cassowary, drc., lad to me the oljects of greatest interest. Only a short time before, some additional bones of this greatest of the wingless birds had been dug up in a moist or swampy part of the plain near the town. The education is chiefly on the Anglican basis, amongst at least the colonial upper or well-off class, who send their children from far and wide in the Colony to this famed and fashionalle seminary. The Aron, wind- 
ing gracefully through these grounds, with its boatbuilding factories, and the neatly finished boats gliding over the waters, might already well recall to our university youth of the old comntry the Isis or the Cam. 


\section{( 201$)$}

\section{SECTION XX.}

\section{CHRISTCHURCH TO DUNEDIN BY RAIL.}

At 8.10 AMr., after devoting, sad to say, rather less than twenty-four hours to see all its features, we left Christchurch by "the Express" for Dunedin, with the prospect of seeing Timaru and Oamaru on the way, but only, alas! during the fly past of our train. The latter had much to show to arouse our interest. First was the handsome little city, built of the famous Oamaru white freestone; then the quarries of this stone, which, on excaration, is so soft and workable as to be treated like wood with the saw and plane; and again the harbour, built with some skill and . difficulty against the tremendous sweep of the Southern Pacific; and finally the wonderful scale and success of the farming over the specially fertile soil of the surrounding country. In short, we had promised Mr. John Reid, of Eldersleigh, one of Oamaru's principal colonists, in answer to his hospitable invitation, to make a halt for at least one day; but from a day's unexpected delay at $\Pi$ ellington, we were compelled to pass on, and to be satisfied with the train's ten minutes' halt.

\section{The Canterbury Plains. "The Gorse."}

For some distance from Christchurch the rast level plain was pleasantly relieved, as I have indeed already partially described, by a variety of objects. There were, for iustance, many plantations of trees, 
occasional small towns, and many neat villas with parks and gardens. Rivers and rivulets were frequently crossed, descending from the continuous snowy range to our right, some of them with a considerable body of water, dismembered into three or four, or more separate streams, and spreading over a wide bed of shingle, which, in several instances, had a width of from one to two miles. These wide beds, on occasions of heavy rains or snow-melting, would be filled up to the brim of the plain, a depth of perhaps six to twelve feet, and on such occasions would roll down a mass of water altogether surprising.

Fifty miles from Christchurch, we began to enter upon a vast area of the plain, utterly featureless in its monotony, and consisting apparently of a quality of land much less fertile than that which we had left. At times the only relief our eye could catch was some slight dividing line separating the estates or pasturages. Over large areas which we passed there was scarcely a wooden house or eren a sod hut visible. We were thankful for the variety of the bright golden flower of the unirersally prevalent " gorse," or furze or whin, so familiar to Scotland. This plant has taken root everywhere throughout New Zealand, and in spite of the natural beanty and sweet perfume of its flower, which was in its highest bloom just at this time, it is apt to be viewed as a nuisance by the colonists, in consequence of its irrepressible overspread. It made, however, most excellent hedges, and the effect of these herlges, distinctly marking out the fields, great and small, far as the eye could reach, was remarkably pleasing. 
Another plant feature, giving also a pleasing diversity, was our old friend once more, the blue gum tree. This tree, remarkalile for its sanitary qualities, has of late lieen introduced throughout Europe and Nortì Africa, especially Algeria, ant wherever, in marshy or malarial sites, it would grow freely. Our English climate is too chill for it. Its luxuriance in New Zealand far surpasses even that of its original source, Australia. There is perlaps, no difficulty in finding the reason, for the tree is naturally of rapid growti, with a proportionate absorption of moisture. The droughts of Australia check this rapid growth, while the frequent forest fires, by scorching the bark, maim when they do not actually lill the tree. Neither of these troubles lappens in New Zealand's more faroured clime, and the tree grows apace, with a swelling stem and an unusually full and graceful foliage. It forms pretty small clumps, and fine roadsile linings, everywhere from northern Auckland to southern Dunedin; and we passed on the Canterbury Plains many plantations of the young trees. These seemed to us to be nurseries for transplantation; but, as we were afterwards informed, they were also of use, when thinned and further grown, as shelters from the warm winds of summer, not infrequently blowing over these wide and sun-heated plains.

\section{Timaru and its Harbour.}

Just before reaching Timaru, one hundred miles from Christchurch, the flat plain began to change into gentle undulations, which, covered with rich 
grass, indicated also an improvement of the soil. The snowy range too had closed in upon us with less than half the distance which separated us at our starting. Timaru, like Oamaru, further south, ventures to defy the ocean sweep with a breakwater harbour, and lias hitherto succeeded, while that of Oamaru suffered two years ago a breach of its breakwater, although that barrier had been constituted of great blocks of concrete locked together with iron. The breach is now leing restored with such still greater strength as is supposed to be adequate to all emergencies.

\section{Oamaru and Harbour.}

During the ten minutes' stay at Oamaru, I had tlie honour of a deputation from the Oamaru Town Council, headed by the Nayor, for the purpose of a consultation as to town and harbour fiuance. Both these interests had been somewhat strained, both by the high interest rates of their early loan issues, and by the late bad commercial times, which had reduced the expected amounts from harbour dues and town rates. My advice to them was to consolidate their various small loaus into one comparatively large uniform stock, which, having thus a more marketable qualiiy, could be issued at a lower rate of interest. Oamaru, they said, would never default, but there was at present so great a strain upon resources as to prevent a variety of improvements that were urgently wanted. I did my best to encourage my municipal friends by telling them that I had advised Sir Inary Atkinson, the New Zealand 
Premier, that if he could join the other Southern Colonies in the issue of an inter-colonial confederate 3 per cent. stock, like that of the Canadian Dominion, these outstanding small high-interest stocks might, with great adrantage to both Colony and municipality, be exchanged for or converted into such stock. I rentured to console my friends with my humble assurance, that, so far as I could judge, during my rapid passage through New Zealand, the late bad times had evidently turned, so that greater prosperity appeared to be before them.

Timaru and Oamaru are about the same size, with some 5000 to 6000 each of population. They are rivals to each other with their two adjacent harbours. Opinion is strong generally throughout the Colony that Ner Zealand is rather orer-barboured, and that it has such a sufticiency of magnificent natural harbours, such as those of Auckland, Manakau and Wellington, Nelson and Picton, Lyttelton, Otago and the Bluff, that colonial finance might have been spared the ordeal of the others. But that is not, of course, the mode of local reasoning. New Zealand, eren more, as it scemed to me, than any other of these Colonies, grasps the facilities of progress, without counting very nicely whether the full time for them has yet come. If she cannot spare her own money for them, she will freely borrow outside. "The full time," she says, "will soon come round, and all the sooner by help of the facilities, whether these be premature or not." This spirit is the secret, chiefly at least, of so many harbours, and such a host of branch railways. It made the Tellington and 
Manawatu Railway, which, when first surrered, like the famous Glenmutchkin line skit, had hardly a house or human being on or near its proposed track.

A New Zealander, in short, in his business dispatch, utterly scorns the old and slow ways. Even the telegraph gets to be too slow, and is being everywhere superseded, more or less, by the telephone. Only the lift convenience seems less preralent than in Australia, whether from the buildings being as yet less elerated, or from that superior vigour of muscle in the Nerw Zealander which delights itself in exercise. But, in all else in that way, New Zealand seems ahead; and I was amused by one illustration-a tiny railway inside one of the banks, which was used to save waste of time and strength in hurling to and fro the safes and other heavy apparatus of the business. But this bright, sunshiny spirit is apt to have its ordeal of cloud and trouble. The ball runs merrily in socalled good times, which, howerer, in their extravagance, are doubtfully so-called; but the last three years have given the Colony, perhaps to its lasting: advantage, a strong taste of the bitter side.

At and beyond Timaru we had a beautiful landscape of undulating ground, the hills covered with grass for pasturage, the valleys and levels cultirated, with the plough actually at work in many directions. We did not see any of Oamaru's great scale of farming, which already threatens to rival that of the Western United States and the Canadian North West, where the steam plough, upon a five or ten mile square wheat field, passes clean out of sight. 
except through a good teleseope. The interior, hut at too great a distance from Oamaru and the line of rail, affords the best illustrations of this progress. We passed, however, some large fields finely ploughed and harrowed.

These Oamaru vicinities were succeeded by a considerable area once more of the monotonous plains, followed yet again by beautiful hill and dale scenery. As we were within two days of the equinox, and our time of arrival at Dunedin was 7.45 P.M., we were, of course, overtaken by the night for more than the last hour of our journey, during which, as we were told, we missed some of the finest scenes. But, by farour of a bright moonlight, we still saw something, and could realise somewhat the grand view of the Otago Harbour, as we passed along, high up upon the precipitous side of its northern coast-line. 


\section{SECTION XXI.}

\section{DUNEDIN AND OTAGO HARBOUR.}

Is point of architectural and business appearance, Dunedin impressed me as standing next to Sydney and Melbourne. It is not nearly so large as Brisbane, nor has it the business stir and speculative excitement of that town in the assurance of a near future of enormous mining development; neither, in point of population, is it so large as Auckland; but there is combined solidity and elegance in its principal streets to which the others have hardly yet come. We quartered at the Grand Hotel, which seemed to me second only, if indeed second, to the Melbourne and Sydney hotels. This hotel is in the very business centre, and around it were the edifices of banking, insurance, and other companies, which might have rivalled the finest in London, the Bank of New Zealand and the Colonial Bank of New Zealand leading the way.

Sallying forth the next morning, as is my custom, for a good walk before breakfast, I ascended a remarkably steep street, culminating in so lofty a site, that I set off for the crown at double-quick in the hope of a grood view. I had noticed the tram rails laid down all along this steep street, and presently I heard the well-known noise of the Melbourne tram carriage coming up behind me. Almost at the same moment another came in sight 
at the top I was making for, and bound in the contrary direction. The ascent was as easily aceomplished by these trams as the descent, and, as there was neither horse nor engine, I recognised the excellent Melbourne method. I afterwards learned, as I think I have already stated, that this unrivalled tram system had originated in Dunedin fifteen years ago, and had been since transferred to Melbourne, to which its originator, Mr. Duncan, had gone for the purpose. Mr. Duncan had, however, introduced it from San Francisco. At the summit I gained my fine view, and in descending I skirted a steep romantic gully on the left hand.

Dumedin has a good deal of such romance in its site, as well becomes the namesake of the MIndern Athens in the old country, any one of whose three grand natural objects, Arthur's Seat and The Crags, the Castle Rock, and the Calton Hill, would be wealth of scenery for any town.

As I was known to be interested in the great scheme of the Otago Harbour, some of the directors, along with Mrr. Mackenzie, the hear of the Colonial Bank of New Zealand, did me the favour of showing me over the ground. This undertaking has involved an enormous outlay of money, far more indeed than was at first intended; but the adrantage of proceeding further and further with the improvement has been so obvious as to have induced the Harlonur Board to pursue their conrse, in spite of grumbling bondloolders and bad times. The chief resource of the Board is an endorwment of no less than 4.50 acres of frontage to the city, at the head of the Otago inlet. 
Nearly all of this acreage has, indeed, to be reclaimed from the sea, and as yet but serenty acres have been so dealt with. But these latter are already covered with wharfs, warehouses, and business buildings, yielding a large and increasing rental, and I could not but infer that, when all the remainder are in similar use, the Otago Harbour endowment, with the progress of Dumedin, may possibly make it one of the richest interests of its kind in the Empire.

Cntil the harbour attained its present depth by dredging and direction of the tidal scour, the larger ressels of the shipping were arrested at Port Chalmers, a small and rather pretty town of 1500 population, on the north side of the Otago entrance, and comnected with Dunedin by rail, the said rail being in fact a part of the main line between Christchurch and Dunedin. But the biggest sailing ressels and steamers now frequenting the port pass straight up to the Southern capital, and are at once discharged and reloaded at the Otago Harbour wharfs.

One lirge steamer from China lad just landed a cargo of teas, sugars, and rice. The rice, which had been "cleaned" by the machinery now used for that purpose before shipment, was in most beautiful order, and, as we were told, would licep so here for any length of time, as the weevil, so destructive in lower latitudes, did not find the cool Otago climate at all to its taste. We went on board to see the curious assemblages of races which make up the crews of these ressels--Chinese, Japanese, Malays, ('oolies, and "various," most of them picked up, as required, at singapore, a place of general call. In 
the afternoon we saw the steamer at the entrance of the harhour, already, with such prompt despateh, on her way lack, there being no available return cargo to detain her.

Some idea of the wonlerful growth of Dunedin in wealth and importance may be formed from the fact that the piece of gromed, now so central, on which the Grand IIotel stands, was hought thirty-fire years ago for $\pm 7 j$ br its present proprietor, who is still alive to enjoy from it a ground rental of $\$ 2000$ a year. 'Juwn values were even higher than now some few years ago, for the lial times of these later years have prevailed here as well as elsewhere, although the collapse has not been so great here as in some other parts, and in particular in orerbuilt and orer-speculated-upon Auckland. The bal times seem to hare opened here much in the way in which they had in a good many places elsewhere. They had commenced with the bad condition of Home trade in 157s, which culminated in the terrible failure of the City of Glasgow Bank, this failure being particularly serere upon the southern part of New Zealand, as the Bank had bolstered up an enormous land speculation there, which, of course, collapsed at once upon this disaster.

But Dunedin has a fair backibone of trading to strpport her. She revels in wool; she has gold too as well as the golden fleece, and slie has golden corn and other cereals, potatoes, butter, and chcese, and the finest beef and nutton, in all but limitless quantity. Slanghtering and freezing of sheep and Lullocks for exportation are upon a great scale. In 
all of these substantial elements of commerce she is in the heat of a close race with her northern sister, Christchurch, which, with her rast background of rich, productive plains, has latterly been rather creeping ahead. They are stalwart rivals, and the race betreen them is equally inspiring and interesting.

Little Port Chalmers, unsatisfied with her mere natural beauties and the dignity of her name, which commemorates Scotland's great theologian and philanthropist, has not taken kindly to the shunted position in which the Otago Harbour improvements have left her. She possesses still the old apparatus of her piers and wharfs, constructed under the larger prospects of the past. Are these to be abandoned without a struggle? Truly no, replies the Port; and accordingly she has launched the scheme of a great dock of her own, in the hope of intercepting some crumbs from the mass of good things that have latterly been sailing past her into the cormorant maw of Dunedin. How the new dock and the old piers and wharfs of plucky little Port Chalmers will fare in the free fight of the future remains to be seen. 


\section{( 213$)$}

\section{SECTION XXII.}

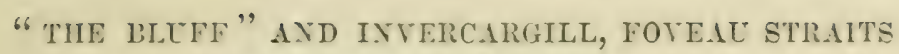
AND STEWART'S ISLAND.

Retorisixg our steamer, the fine fast "Tairarapa," at Dunedin, as we feared we might be too late to meet it at The Bluff, if we delayed about six hours for the railway, we passed out of the Otago Harbour, having this time the full advantage of the daylight to adnire its very considerable beauties. The southern side forms a peninsula, whose northern or warm exposure, rising in fine grassy slopes, of considerable elevation, from the harbour waters, affords delightful sites for residences, .much pleasanter, one would think, than the opposite or colder slope. But the convenience of the railway has as yet sent the residents nearly all to the latter. They inclule a large proportion of the working classes, whose tidy little mansions and plots of gromul, for the most part their own property, were scattered in lively variety over the hill sides.

\section{A Nerv Zealand Storm.}

Shortly after clearing the harbour a furious southwesterly gale came upon us, which delayed our traverse of the 113 miles of distance to cighteen hours, or nearly twice the usual time. Althought most of us were seriously discomposed, and the next morning's brealfast table presented, as to occupants, 
a sadly mutilated spectacle, we had all to confess to an admirable boat, which with its powerful screw pushed nobly through the raging head sea. We were especially pleased with the ready obligingness of all the stewards, and the special tidiness of the cabins. We learnt one cause of the latter, namely that there is an inspection of all the berths every day, the captain, in company with the chief steward, making the regular round an hour before noon. But I have since heard that, in well-regulated "Lines" this is the common practice and precantion. We entered The Bluff, with the comfort of its smooth water, but in a wind almost enough to lift us bodily off the deck into the sea.

\section{The Bluff Harbour.}

"The Bluff," which is the handy designation common to the harbour and the little township of about six hundred of population which has arisen upon the western side of the entrance, is a capacious inlet forming an all but completely landlocked shelter from the frequent furious gales over the outside ocean. It is still larger than that of Wellington, and therefore with still more room to accommodate all the navies of the world. But it is sadly deficient of any other charm save this amplitule of area. The surrounding secne was in fict the poorest in every way which we had met with in New Yadaland. The ground was mostly covered with what I might call scrub bush, varied by patches of small stunted New Zealand forest, not mulike in kind the tangle of 
forest we met with at intervals along the Manawatu Railway, but sorely monotonous in complarison, ancl deficient, in this chiller climate, in the dignity of generous growth and variety.

\section{Invercargill, a Model Town.}

The sudden plunge from this dreary scene into the urban beanties of Invercargill was a pleasant surprise. This is, for its size, the most elegant little city in my recollection. Its broad. straight, rectingularly plamerl streets. with already their fair filling up, in the central parts at least, of neat and sulstantial buildings, give eren an imposing as well as a pleasing effect. But Invercargill, after a culmina tion of great hope and speculative anticipation ten to fifteen years ago, has suffered a rather severe reaction. Its population had reached, a few years back, 10,000 for the town and suburlss, from which, however, it has since receded by about 2000. This has been caused chiefly by the departure of some of the working classes, who found that the orerbuilt place was no longer employing or paying them ats formerly, and who therefore have been streaming over by the fortnightly steamer which calls at Hobart en route to Melbourne, and thus gives the chance of the two labour markets.

With us in the "Wairarapa," there were, as I was told by some of themselres, no less than 250 of these working men, who had come on board between Auckland and Invercargill, but chiefly from the Southern Island, as passengers can go more directly 
to Sydney from Aucklind and other places of the North Island. Some whom I accosted on board our steamer spoke rather bitterly against New Zealand and its Government, and against its employers in general. But I could see that erery thing looks wrong. when one's own interests are touched. Some of them complained of having lost all their savings as well as the high wagres of the past. That is to say, as I inferred, they have bought their little acreage, and reared their cottage upon it by premature help of borrowed money, and, as bad times had reduced the value of the whole estate below the horrowed amount, they have thus lust the whole. One man declared he had lost $\Perp^{\prime} 1500$, and in this unsatisfactory way as I supposed, although the subject was rather a delicate one to probe him upon, and he added that New Zealand would not see his face again in a hurry.

My fellow-royager's assured me that as many as 1300 a month, chiefly working men, have of late been leaving New Zealand. This is certainly very seriuns, and the fact appenrs to militate against my idea that the Colony has turned round from the late bad times. But, no duubt, a slack interval is inevitable between the wind-up of the old condition and the effective start of the new. I endeavoured to comfort my informants with what seemed to me the prospects of early improvement, which must, I thought, bring these deserters back ere long to the surpassing climate they were leaving. The quality of the climate they freely admitted, but of the other benefits they seemed still doubtful.

Invercaldgill, howere: hats behind it towats the 
north an extent and quality of fine lind which insure it a great future after the speculative ups and downs of the first start have ben adjusted. The Dunedin merchants already apprehend a rival race here as well as at C'hristchurch. The climate and products of Dumedin and Invercargill are much the same, and the latter las also facilities of shipment by means, for the present, of the Bluff Harbour, twenty miles south by rail, with, however, the prospect of more direct sea access some diay by Invercarcills own special inlet rumning alongside of the Bluff. 'This inlet requires considerable deepening, and it hias also the additional drawback of a sand-lianlied entrance, so that the superseding of the Bluft, like another Port Chalmers, may still be far distant.

Here we hal to lament, not for the first time, the want of leisure to see the marvels of the country s scunery, particularly the great lakes away amongst the lofty langes, north of Invercargill, aud northwest of Dunedin. These likes receive such rast water supplies from the suow-clad ranges and the riiny regions of the west coast, that they send forth rivers of continental magnitude. The Clutha is the principal of these rivers, and I am informed, although to me incredible, that its water discharge is as much as that of the Nile.

Stement's Istumel and Fuedue stmit, and the ir Oysters.

Stewart's Island, and Foveau Strait which divides it from southern New Zealand, were another surprise to me. I had preconceived the former, from its far 
south latitule, to be some inhospitalle shore, mainly occupied by seabirds. On the contrary, it is a heautiful land, full of picturesque inlets and natural harbours, and with a surrounding of islands of rical beauty like a queen planet amidst her moons. Patterson Inlet, on the east side, is the chief resort of northern visitors. Near it to the north is Half Moon Bay, where the village capital is situated, and where the Bluff Harbour Board dispatch weekly throughout the rear a small mail steamer, sulisidised by the Colonial Gorernment. There is an increasing number of risitors during summer months, when the comparative coolness of the climate is most attractive. Tisitors begin to arrive from afar. For instance, Sir William Stawell, from as far off as Melbourne, J heard, had paid lately a pleasant and healthful visit there. The winter, relatively spealing, is hardly less enjoyable than the summer, for, with the sea surrounding, the climate then is even miller than that of Southland or Otago, opposite to Stewart. One colonist, who has long resided upon a pretty islaud of Patterson Inlet, prides himself in having a garden, where trees, shrubs, and flowers, including even some of the Norfolk Island pine kind, which would die in the winter of those other districts, can live and flourish.

But even these other districts, Otago ant Southland, forming as they (lo the southern parts of New Zealand's main island, are decidedly milder than that senion, Britain, with which they are cencrally complared. For instance, my friend the IIon. Mr. Fergur, Minister of Defence, who belong:- 
to the central Otago district, tells me that the gral ripens there, and in large quantity.

The same gentleman mentioned to me what scemcd to he a curious pliase of one part of that great and varied district of the Sonthern Istand. IBeing lately on a visit to a little villiage called Macetown, situated in a small glen upon the Arrow River, between the Wakipu and Wanaha Lakes, and surrounded by mountains so high as to he, more or less, under perpetnal snow, the place being in fact a part of lis electoral constituency, the schoolmaster cilled his attention to a remarkable circumstance amonges the two dozen or so of his pupils. This was that crery one of them-and all were born in the place-haul either white or decidedly fair hair, while their parents taad the black or dark hair usual to our people. I replied that I had never heard that Switzerland and many other places, which contained areals full of that sort of cold whitening, latd prodnced such remarkable effects. IIomerer, as the circumstance was noticel by so good an anthority as the local schoolmaster, I hare thought it worth recording.

Stewart's Island used to be called the Southern, and the two others the Northern and Viddle Islands; but latterly the comparatively small size of the former las been grailually excluding it from that principal position, so that now it is more common to speak of the two main islands only, and call them the Northern and Southern. Stewart's, like the others, is reputed to be rich in minerals, including gold, which seems to he diffused throughout almost 
the whole of New Zealand, although as yet but slightly worked anywhere for want of capital and adequate suitable machinery.

But Stewart has another product hardly less acceptable than its precious metals, namely, its oysters. Gold, silver, and oysters are the three things of the world for which there is a neverfailing market. The orsters are large and fat to a degree that rather turned me from them, as I am not a great fancier of the raw commodity; but they set some ladies, who had a reakness in that direction, off into ecstasies. These are, to some extent, mud orsters, but not entirely, for there is not properly any mud about Stemart's Island, but only some sand mixed with a little mud; while the smaller kind from Sydney, Auckland, and elsewhere are rock oysters.

It was supposed, until some rears ago, that only Stewart had these grand oysters, but now they are found all along both sides of the Straits. Just at present they are frequently gathered from Ruapetu Islant, one of the possessions left to the few Maories of this part, as they are more easily and plentifully picked up there. Our steamer had on hoard, besides beef and other products from Dunedin, 320 casks of these fine orsters, containing 66 dozen each, fresh gathered from the Straits. These slipments were made every fortnight, and were disposed of at Hobart and Melbourne.

The natives, who include a proportion of halfcastes, do a great deal in oyster fishing, and their brethren, from as far off ats Anckland, come south to 
share in the trade. They use small ketches, or large decked hoats, with mast and sails, of which we saw half a dozen anchored in the Bluff. The oysters have a "close" season, as at Home, which is the four months October to January. But it is found necessary here also to give at intervals a longer rest than this, and accordingly the beds are tabooed periodically for one, two, or three years, in order that they may the more effectually recruit.

The natives have a large trade hereabout in another very favourite article, the young of the mutton bird. This bird might be described as a kind of sea duck. It is very plentiful, to those at least who have the skill to find and catch it. Only the very young bird is eaten, whether from the tougher and more fishy-flaroured quality of the senior, or from economic considerations about preserving "the goose for its golden eggs." The nest is a long, rather horizontally directed loole in the ground. The natives, by a tap on the ground over the nest, can tell if the birl is below, and then, by a long insertion of the arm, they bring it forth. It is like a little down-covered ball, with a surrounding of fat or grease an inch in thickness. The natives are excessively fond of this rich morsel, which they devour, fat and all, after a half-hour's cooking's; but colonists, on the other hand, cannot face so much fat, which they, therefore, reduce by a severe frying process, after which they secure a fairly palatable dish. 
An Interesting Story of early Colonial Life.

Nuch of this and other information about New Zealand was given to me by Mr. Frederick Rerans Chapman, barrister, or rather, with the amalgamated profession in the Colony, solicitor-barrister, of Dunedin, and one of the sons of my old friend Judge Chapman, of that city, who, in my time at Melbourne, was Attorney-General of Victoria. Amongst other things, he gave me so charming a story of his father's carly colonial life, almost bringing back into existence the old Pilgrim Fathers, that, although it refer's altogether to another place than Australia, I venture to introduce it here, as it would be an acceptable audition to any colomial history. His father cmigrated very early from England, so early in fict as $182:$. when he settled as a merchant at Quebec, remaining there till 1832 , when he removed to Montreal, where, in conjunction with his partner, Mr. Tievans, he established the first daily paper. In the year 1824, young Chapman, in company with some other adventurous youthe, procured a small steamboat, then a very rare article, and sailed from Montreal for an excursion over the lakes, the very first trip of the kind made in that way. They steamed as far as the head of Lake Michigan, whose western shore areats were then an almost empty territory. At this place they met a small United States Government surveying larty, from whom they learnt that it lad been resolved to begin a township at the Lake's Head. 'This purpore, in fact, was publicly intimatul, and a plan of the proposed town had been 
drawn up, with the land laid out in lots to be suld at a dullar each. There was some joling amongst. Chapman's party at this expected sale, and one of them got up a mock anction, at which the lots were put up at the dollar as a minimum. But for some reason or other the real sale did not then come off, posibly, as Mr. Chiapman suggested, and as wats not infrequent then, becanse the probability of the lideding was not sufficiently encounaging. The sale was put off till some years later, and the township thins contemptuonsly treated was no other than the great modem Chicago.

\section{Another Talk with Working Men.}

Ere our royage from 'The Bluff to Hobart enderl, I had the opportunity of a talk with a numlier of working men who were leaving New Zealand for want of work, or rather, as they explained, for want of reliable regular work, and were bound for Melhomme. I hive alrearly alluded to this sulject. They were complaining a good deal of the Colony, as though "the whole thing" were a sort of "take in." I listened to them with a good deal of interest, and endearoured by cross-questioning to make out their exact case. From their replies, checked by other information, I made it out to be somewhat as follows. There had been plentiful work and good wages up to two years ago, when a decline began, which got grachally worse, and grew into a positive crisis for the last six or scren monthe, 
when a sort of stampede of the rorking class to clear off from the Colony commenced, and has gone on until now. For example, they said, there are now in this boat 200 to 300 morking men in flight for Melbourne, and these numbers go regularly hy each weekly steamer to Melbourne, hesiles those who go from Auckland to Sydney. For these seven months, they added, some 1300 a month have thus emigrated.

I was quite astonished at this statement, but on further inquiry I had reason to think that, although quite undesigned, it was a somewhat negligent orerestimate. In order to test its correctness to at least some partial extent, I rent to the captain, with the request that he would give me particulars of the numbers, sex, and age of the steerage (second class they delicately call them) passengers. He brought me the following list: men, 101; women, 31; children, 41 ; total, 176 . Evidently, therefore, there was great exaggeration, besides that, as the captrin and others stated, some of the men were not workpeople. A few, for instance, were bound for the Ielbourne Exhibition, and, although in fiir circumstances, went second to diminish the expenses. One of these, with proper politeness, had sent his wife to the first calbin, himself taking the second. Further explanation came in reference to the Colony's late course in railway-making. Obliged to contract greatly this tro-extravagant railway expenditure, many hands had been discharged, and no doult most, of this surplus labour arose from this cause. 
There was another distinct cause for diminished employment, due to the men, by their Cnion's influence, refusing lower wages in lad times, and from their election influence virtually compelling the Goverument to continue the high wages of the past, and to pay eight shillings a day when a private employer need not have paid more than six shillings. This had the effect of making work so costly in the Colony during these late depressed times, as greatly to arrest improvement outlay, and consequently to diminish employment.

Yet another calse of complaint came cut, to which indeed I have already alluded, when I described some of the working men as having said with a growl that they had not only lost their employment and wages, but their savings as well. The fact is that the general spirit of going ahead, or anticipating the future, and jumping over slow time, by borrowing money, had invaded the working man as well as the land speculator. It was more legitimate, no doulst, in the former case, but that did not sare the usual consequence. One of the colonial features, and an excellent one too, was the numerous working-class holdings of a cottage and bit of ground. But the temptation to precipitate matters by getting a loan upon the half-finished house had been great under the prevalent example in the ranks above them. Bad times would then orertake them, and a 50 per cent. fall - no infrequent case - would, as I said before, simply leave them penniless.

Perhaps one is hardly to be surprised at the conclusion that these working men cane to-mani- 
mously, as far as I could see-namely, that the Colony was already over-peopled with the labouring class; in fact, as it seemed to them, over-peopled altogether. They roundly abused the Government and the employing classes of New Zealand, who still called for more and more immigration, they said sarcastically, when we who have been bronght out here are running away again from "the blessed country" as fast as our leg's can carry us. To this I remarked that the main aim in colonisation was to secure a piece of land, and thus people became employers of labour rather than employés, but that there had been much extravagance and speculation of late, which had temporarily disarranged the usual course and relations, and that it must be utterly absurd to call this vast, productive, and beautiful country, with the merest handful of people, over-populated.

I also touched upon a rather delicate point, by adding that they themselves stood in their orvn way for the restoration of normal conditions, by refusing to turn their hand to any other work when their own particular line was for the time run out, and by their insisting upon the rates of wages of good times, when the Colony could not for the moment pay such wages, and when the other classes had all to cut their coat according to their cloth. MLany an em1)loyer, I said, would now be glad to make even half the wages they were asking. Some gave a ready and cheerful assent to these points, but evidently the majority sulked " distemperedly." The Government, I may add, feels so acutely the diffieulty it is often placed in ly this systematic demand, especially in 
bad times, for excess wages in the pullic service, that it is seriously contemplated to establish an independent Commission, which may deal with their employés with more of the freedom and fairness which would be possible to a private employer. 


\section{SEUTION XXIIT.}

RETURN TO HOBART, AND ONCE MORE TO MELBOURNE.

ONCE more we were doomed to enter Hobart's grand harbour by night, and by the same unwelcome mode we had, twelve hours later, to take our departure for Melbourne, so that we did not see the fine entrance to the Derwent estuary. The Governor and his lady were absent, fishing at New Norfolk, so that we missed them also. But we found Mr. Premier Fysh and Mr. Bird, his Treasurer, who both did me the honour to accept a luncheon at Westella, to which we again betook ourselves, and where we re-discussed the prospects of Australasian 3 per Cents. Both my honourable friends seemed to have made up their minds " to go for Threes," and the next step was to induce the other Colonies to go with them. I duly made my report, to the effect that both Victoria and Sonth Australia, which were likely to require more borrowing in about six or seven months, were to give the proposition due consideration, and wonld probably, as the time approached, refer the matter to the respective Agents-General in London. That, of course, was all that could be expected for the present.

Hobart looked charming as compared with its aspect on the previous wintry occasion. Now all the tide of beautiful spring life was upon the scene. The trees were laden with fruit blossom, the sub- 
urban gardens were full of flowers, and the green grass sprung up over all otherwise unoccupied surface. But we had unfortmately no time for jaunts, however pleasant they might now have been. My namesake of Westella, however, took us a drive down the Derwent to Sandy Bay, which must needs satisfy us for this time.

The next morning broke in stillness and sunny beauty, to find us just off the north-east bend of Tasmania. The coast stretched westwards towards the Tamar entrance, while southwards, in the Tasmanian interior, arose upon the horizon the lofty back of Ben Lomond, about 5000 feet in height, still covered with last winter's snow. But our interest centred chiefly in the long succession of islands that came upon our north-westerly course through Bass's Strait. Having entered the minor Banks' Strait, with Clarke's Island on the north hand and its 170 settlers, we passed the rest of Furneanx Group, the little Pyramid Rock, Curtis Island, and then sighted the well-known Rodondo, which was always a landmark of forty years before, in our royages to and from Sydney. Then we made out W'ilson's Promontory, the sonthern headland of Australia, which there dips into the cool waters of $40^{\circ}$ sonth latitude. Night overtook us long ere entering the Port Phillip Heads. Next morning we stepped ashore upon Melbourne Wharf.

After once more installing ourselves comfortably at "Scott's," which, by the way, had been sold shortly before for $£ 120,000$, and let for five years by the buyers to the previous managers-for what 
rent I did not hear, although the purchase price may give some idea as to what things are "booming" to in Melbourne-we set about to complete our Melbourne engagements, and to take what time remained to see a little of the Victorian interior. 


\section{SECTION XXIV.}

MELBOURNE 'I'O LILYDALE AND FERNSIAW.

We had postponed our country excursions as much into the spring weather as our time of stay would permit, and our first trip was to Lilydale and the mountainous region of the Upper Yarra beyond. We went upon the invitation of Mr. Cowderoy, Secretary to the Melbourne ('hamber of Commerce, and Mr. Reid, President of the Chamber, with Mrs. Reid, accompanied us. Our companions, knowing, as they did, most of the localities and their people, contributed greatly to our enjoyment. Passing the protracted continuity of the Melbourne suburbs, with almost countless pretty cottages and gardens, we entered diversified undulating scenery, mostly of verdant and fertile-looking land, but without particular feature till we reached Lilydale, about twentyfour miles from Melbourne, where we breakfasted, for we had started by early morning train. The lands we passed through had risen in value very considerably during the last fer years, with great acceleration in the last twelve months, due to the reigning "land boom" in Melbourne. Suburban Melbourne generally, in this direction, had risen during the year quite 100 per cent. Indeed that rate of rise, great as it seemed, was held quite inadequate to the ambition of many holders of the land. 


\section{Small Inland Towns: their Similarity.}

We left the railway, and drove on to Healesville, a town of the future, but as yet in the far wilderness, and were saluted with ever-increasing natural beauty as we advanced inland. We passed on the left the St. Hubert vineyards, where some of the best wines of Australia are now produced by Mr. De Castella. This was the old Yereng cattle-station of the Upper Yarra, where I visited, forty-five years before, my late most hospitable friends William and Donald Ryrie. We went as far altogether as Fernshaw, about fifteen miles beyond Lilydale, near which is to be a water-reservoir for additional supply to great and growing Melbourne. Some few residents, including a hotel-keeper, had been bought out by the Government, in case their vicinity and their doings might in any way taint the future water supply. Our friend of the hotel, who turned out to be an early acquaintance of mine, was no ways loth to quit, remarking that our $\mathrm{Mr}$. Cowderoy, who had been the official valuator, had allowed him enough to decide him to retire from business for his few remaining years. We also encountered here the railway surveyors, who were pegging out an extension line enstwards towards the upper Goulburne River.

Interior towns, or "townships," as they are at first called, have here as elsewhere much similarity of look. The streets are always rectangular, and usually conveniently wide. The first and most conspicuous edifice is the hotel or "public" as it 
is summarily called, and which is not seldom a solid stone or brick edifice. The next is the blacksmitli's forge. 'Then cottages, mostly of wood, straggle like pigmies along the edges of the wide grassy streets. Then a little church or two, which have, at least, a better chance than the cottages of being of stone or brick, like the "public," although of far inferior dimensions. The public school early rears its modest head, and one of the pleasant sights to us as we passed through both Lilydale and Healesville was the squads of boys and girls, with their satehels and books, playing on the roadside, or throwing an envious glance at us as we cracked the whip over our horses and sent them speeding past. Corner allotments sell ligh in these nascent Melbournes; they will bring as much as $£ 500$ an acre, and they are apt to be held on unused in the hope of higher and still higher prices. This is an evil very properly checked of late by rating such vacant and unused property at its fair value of the day.

\section{Forest-clad Mountains.}

At our furthest in this Fernshaw direction, the entire scene was of hill and dale covered everywhere with forest, mostly of the various gum trees, many of them of great size and height. The hills themselves are of no great height, till you go some distance further eastwards, approaching North Gipp's Land, where they rise to from 5000 to 6500 feet, with perpetual snow on the highest summits. The beauty of this uniformly forest scene is, of course, somewhat 
monotonous. The trees are larger and less injured by bush fires here than in most other parts of my tour. Our road continued on to Wood's Point, some sixty miles beyond our furthest, and a place famous for gold-digging "rushes" some years ago, although less attractive just for the present.

There we pulled up to return, in a great valley full of tree-ferns as well as great tall gum trees, there were two large specimens of the latter, one being thirty-six feet, the other about sixty feet, in circumference. The examined the smaller one, which was on the roadside, but the larger, being in a tangle of long grass and bush, all wet with a heary rain at the time, we did not go to. One has usually no conception of the actual size of such trees till getting close up to them. Fernshaw had already some pleasant little gardens, with trees loaded with fruit blossoms, all of which lad to go, the flora as well as the fauna, human and other, before the official order to clear out in the indispensabie interests of undiluted water supply.

\section{An Aboriginal Native Reserve.}

Our return journey was pleasantly and most interestingly varied by a call at the aboriginal natives reserve, situated between Healesville and Lilydale, under the charge of Mr. Shaw. That gentleman, who was at first a lay reader in the Anglican communion, is now in charge of one of the batches of the waning remuants of the aborigines of the Colong. They now number, in this place, about 
ninety in all, consisting of some old men and women of pure blood, with a large gathering of young, of whom a good many are half-castes. The respective families are mostly housed in small quito Englishllooking cottages, partly, if not wholly, huilt by themselves, and nearly all of wood, with, however. an occasional brick edifice. We noticed one aboriginal "mi-mi." made of bark, which probably some defiant old native still preferred, or pretended he preferred, to the specious superiorities of the white fellow. There ras a church, a school, a store or shop. a flour-milling place, and other signs of civilised activity.

As we drove in, the wet weather had sent nearly every one within the houses. But old and young soon came trooping out to see us, while many a little face pressed its nose against the window-glass in staring out from inside. All spoke, more or less, fairly good English. Unfortunately for us, Mr. Shaw happened to be away at the time at the railway-station, some miles off, to bring back his wife, who had been to Melbourne. This was a misfortune to us in more than one sense, for, when we began to truck and traffic, we had reason to suspect that unconscionable prices were put upon the wares, under the providential opportunity of the master's absence. The articles of chief attraction were large and small baskets, made, with wonderful neatness and finish, from the green rushes growing plentifully all about. There were also boomerengs, clubs, and other aloriginal weapons, These articles, particularly the boonereng. 
are still made fairly well, in response to constant demand from visitors, but the old expert use of this famous throrving instrument, with its remarkable retrogressive path, is all but lost to the aboriginal of to-day.

When we indicated our disposition to make purchases, two old men came out from their respective dwellings, and seemed to be the agents or directors of the dealing. They were most markedly aboriginal, apparently sixty to sixty-five years of age, stout and healthy looking, very black in the face and getting very white in the hair. The entire party seemed cheerful and contented. They are much more so now than they were, or would have been, under like circumstances, twenty to forty years since. Many instances are given of the tenacity of aboriginal nature in those past times. The boys and girls show quickness in early schooling, hardly less than that of white children; but as boyhood passes they fall off in steadiness of application and progress, with a tendency to return to aboriginal life. One young man, who excited much interest by his talents and scholarship, was sent some time ago to Cambridge to finish, and did so with honours; but, on returning to Victoria, he voluntarily abandoned all his educational and social attainments, and returned to the parental ways, quitting the civilised home, and throwing off its trappings apparently without any regret. There is not now, however, the same difficulty. The young people go fairly through their lessons, and as they get older engage in agriculture or gardening, or in basket- 
making or other work. Their locality here is found particularly favourable to hop-growing, and that rocation is much taken up by them. There is another such native establishment in Gipp's Land, with a rather larger body of natives in charge. 


\section{SECTION XXV.}

\section{MELBOURNE TO LANCEFIELD.}

Trins was another trip to the Melbourne vicinities, about forty-six miles northwards, to which we were invited by certain parties who were interested in establishing a large brewery in that locality, and who asked me to see the place and the beautiful water, an analysis of which showed it to be, for brewing purposes, superior to that of either Burton or Edinburgh. The chief of the party was Mr. Lindsay, an experienced brewer, and he was accompanied by another who was also interested, $\mathbf{M} r$. W. J. Disher, a very old Colonist, and son of an old and respected acquaintance of mine, the late manager of the Edinburgh and Leith Brewery Company of Edinburgh.

A Remarkable Colonist, the lute MV. W. J. T. Clarke.

We passed at first through a somewhat tame and level comtry, but ererywhere covered with grcen, green grass, and most of it apparently of more than average fertility. The great bulk of this magnificent property, to the extent, I was told, of 26,000 acres in one block, is the property, or more properly only one of the properties, of Sir William John Clarke, Bart., of Melboume and Sumbury, whose beautifil 
country residence at the latter place we saw and arlmirer, as we passed northwards to our destination. He has other vast properties between these parts and Ballarat, and a mansion, or rather palace, in Last Melbourne, only just completed, and probably the grandest of its kind in our southern empire.

Sir William is the eldest son of a most extraordinary man, the late Mr. W. J. T. Clarke, of Tasmania and Victoria, who left us lessons in the art of piling up a vast fortune. I often met him in Tictoria's early days. His large and busy head, his tall and robust form, his rough but energetic and commanding way gave the impression of one who, while ostensibly engaged only with his own private interests, acted like a pitchfork upon his Colony's progress. He cared nothing for spending his money upon himself, for to the last he retained the simplicity of his earlier bush or squatting life; and he had, perhaps, as little as most other business mon, the miser's mere love of money. But lis great delight was the employment of making the money, together, no doubt, with the pleasing consciousness of his art or power, above other men, in doing so. He reminded me of a story which I heard long ago of one of the elder Rothschilds, who was also one of the richest of the family group, and who, on being asked what possible need he could have for so much money, replied that he needed it all as a basis for making more money. Mr. Clarke left three sons, each of them enormonsily endowed in lands and other effects, situated in Tictoria, 'Tasmania, and New Zealand. 


\section{Brewing, and the Importance of the Water.}

At Lancefield we were close to the rise of the Salt Water River, where the "creek," as it should be called, rather than river, with that word's idea of a constant stream, has the common Australian feature of a succession of water holes, some of them both large and deep. Mr. Lindsay's brewery here stood upon the bank of one of these great holes, of about forty feet in depth, and which never dries up, even in the severest and most protracted drought. It seems at first curious that such deep holes are not filled up gradually by the mud and débris of stones or trees brought down from above. One is left to suppose that the sudden and violent floods of these creeks clear out the holes at times, as well as fill them up, and are thus in fact as likely even to deepen them still further as to silt them up.

There was a good stream in the little creek at this time, with the water slightly muddy, and of a distinctly bitter taste, probably from the heavy discharge of gum tree leaves that ever pours into such creeks, lined as their banks usually are by this commonest of Australia's trees. But some springs close to the creek had beautifully clear and fresh-tasted water, which, along: with a larger additional supply a few miles off, was to be the fundamental element of a proposed great extension of the brewery. The chemical analysis of this water had been given, and a couple of large bottles of it were intrusted to my care for conveyance to London, to compare with Home varieties. 
Lancefield is already a pretty and promising little town, with the usual wide rectangular streets, indicative of the common ambition and the expectation of a great future. The place was not without its resnurces and gaieties. Mrr. Little, J.P., an old colonist, with his wife and two danghters, received us hospitably, and gave us tea, still the universal bush beverage. They discoursed too of balls and dances in the neighbourhood, while, in our peregrination through the streets, we noticed a public library. There were probably a hundred houses in all as yet, but Australian towns or townships are apt to make sudden jumps. The surrounding country was extremely rich and fertile. The crop most in farour seemed to be peas; but everything else appeared to grow profusely. This soil had been mostly heavily timbered, but its quality admitted of an expense of from $£ 15$ to $£ 18$ an acre for clearing. and the land thus cleared was valued now at $£: 0$ an acre. Let us compare this price with $£ 10$ to $\mathbb{E} 40$ an acre, at which much land in populous old England is now selling.

Sunbury is another such small township, with a neighlourhood of pleasant and varied scenery. $O_{n}$ the left hand, going out from Mellourne, we harl some pretty green hills, the nearest of which, MIount Aitken, was the pastoral station of the late Mr. John Aitken, one of the earliest pioneers of Tictorian colonisation, and, along with his fine wife, now Mrs. Kaye, and young family of the early dars, recalling some of my most pleasant memories.

In front of Lancefield are two picturesque hill 
ranges; on the left that of Mount Macedon, so called from a fancy of its explorer, Sir Thomas Mitchell, and a most conspicuous object to the North West from Melbourne; and on the right hand the Dividing Range, whose northern slopes send their considerable contributions to Australia's chief river, the Murray, while the southern slopes, on the contrary, send only some comparatively tiny or intermittent water-courses into Port Phillip, the Yarra Yarra (meaning in native tong'ue the Ever-flowing) being the triton amongst the minnows of the small family. The cool heights of Mount Macedon, little above an hour's railway journey from Melbourne, are a farourite summer residence, where are to be found the Governor of Victoria, and my banking friend Sir George Verdon, and others of the richer citizens of Melbourne. 


\section{$(24.3)$}

\section{SECTION XXVT.}

MELBOURNE 'TO GEELONG, QUEENSCLIFF, AND

\section{BALLARAT'。}

Is order to sce these places effectually, we had resolved to sacrifice no less than two days to the three towns. Geelong was an old and admired friend of mine. "Pretty Geelong" still ring's in my ears from old recollection, and I wanted to see how she looked now in her maturer womanhood. Then, again, Queenscliff had no existence in my time, ercepting her two lighthouses, while now, as I heard, she was, in the summer season at least, a cay and overflowing watering-place. Ballarat ton had leen horn under my rery eyes, and had not come into existence until I had been eleven years in the Colony.

Starting about eleven A.M., we reached Geelong a little before one o'clock-no great speed for fortyfive miles of distance. Te traversed a rast plain, which, in my earlier time, was devoted to squatting solitudes, but which was now, on all sides, alive with small towns and hamlets, cottages, and farms, and gardens. But there were still the old wimling creeks, the Koroit, the Little River, the Werribee and others, none of them of peremnial stream, but rather each of them a series of water-holes, marked out by the winding lines of self-planted gum trees.

About forty years ago I made the acquaintance of R 2 
one of these water-holes in a rather troublesome way. Driving with a friend in a dog-cart from Geelong to Melbourne, in crossing the Little River, me decided to give our nag a drink, after his long journey, at a tempting-looking water-hole. It was a small hole, of only about thirty feet diameter; but, althongh of unknown depth, there was the appearance of quite firm footing right down to the water's edge. We had expected that the horse, with the usual instincts, would have paused at the edge, and have managed to stretch his neck till his lips reached the water. But, instead of that, he made just one short step) over, and down he went like a stone, with the velicle and the two of us almost on his back. Tre ourselves got out safely, and with some trouble we at. last backed out the dog-cart, luut by no effort could we in the least extricate the horse, which vainly floundered about until quite exharusted. Fortmately a dray and bullock team hove in sight some hours after, and, by means of a rope which we contrived to get under the horse, the team promptly laauled him out upon tera firma, but half dead from cold and fatigue. Indeed he required a montl's recruiting ere we could take him back to Melbourne.

\section{Geelong.}

Geelong; pretty as stie is acknowledged to be, has not progresecel like the rest of Tictorial. At first, for more than a dozen rears, leer fune situation, as the outlet for a great wool production, sent her rapidly alsanl, and she threatencel Mellomme with a 
formidable rivalry in wool and other shipments direct to Europe. At the critical turning point of the gold discovery in 18.51, if she could have at once made a railway direct to Ballarat, there is no saying what might not have been Geelong's fortmes. She is much nearer to that rich field than Melbonme, and with an easier construction of railway line; in fact. the direct line from Mrelbourne to Ballarat is not even ret finisher. But Dr. Thomsin and the other Geclong magnates turned their rail efforts, not to Ballarat, but to Melbourne, thus plitying, in all immocence of course, into the hands of the enemy, who quite complacently allowed them the rope to hang themselves.

But nothing can deprive Geelong of her fine site, and her "quiet as a mill-pond" harbour. She had male such improvements also, since my time, as to be now all but unrecognisahle. I male out my late friend Mr. J. F. Strachan's house, on the hay shore, a little north of the town; but oll Mack's Hotel had an olscuring dress-doulthes, however, a more ornalmental one, in the character of a neatly got-ny temperance coffee pralace. Unawed and unrepelled by this novel style, we took up our quarters there for our one night's visit. There was a large won warehouse of C. J. Dennys \& Co. -an old local name-near us, and there was a botanic garden within the town linits, together with many wille and rariegated streets, full of good homes and lretty cottages with garilens. But Geelung. with about 20.000 people, has been stamding still, while sister fuwns or cities, muthly Ballatat and simulhurst. 
have been dashing ahead, the former being already far in advance of Geelong even in population, while the latter is close upon her heels.

\section{Queenscliff.}

Early in the afternoon of our arrival, we went on by train to Queenscliff, on the western lieadland of Port Phillip entrance, twenty-two miles distant. There novelty in every form a waited us; long and wide streets, good hotels and churches, and the new feature to me, par excellence, of a military defence system, brought up, as I understood, to the very hour in all modern effectiveness. Withal, however, the place was at present in the extreme of quiet, not only because there was no enemy to try, in the literal sense, its metal upon, but because the season had not yet, by almost two months to come, set in, when hotels, shops, streets, and so on, would give a very different account of themselves. We duly met there, as expected, Major Daniell, the commandant, son of my London friend and South Kensington neighbour, Colonel Daniell; and with the Major, one of his lientenants, Mr. Wm. R. Christie, son of another of my old friends at Home, and already, under his soldierly chicf, also a very soldicrly-looking young fellow.

\section{Military Defences.}

As there was so little else to be seen at present than the military department, we entirely resigned ourselves, and our whole two hours of time, to Major 
Daniell, and had good reason to think, when that time was up, that we could not lave spent it better. The arts of defence-in the interests of a peaceloving empire, I prefer that word "defence" to its antithesis, "offence"-make such rapid change and progress, that, if one is not often in contact with it, there is only one succession of surprises. And so we found it here. For instance, the old system of pointing guns by hand and eye, and letting fly at the enemy with trust in Providence for a hit, and with many in miss none the less, is entiruly done with, and in its place has come mathematical certainty. Two small reflectors are placed in line on the gun's side, one to take up the enemy's ship, the other to pass the reflection on the waiting gumner's eye. The instant the ship comes into this line-there having been of course preliminary preparation to that effect-- the electric is discharged, and the shot goes straight to its object. Nor is it necessary in firing, even to stand beside or near the gun. Major Daniell took us upstairs, where, upon a small innocent-looking table or desk, was a map or view of the Harbour opening, with some slight "finding" apparatus, through which a subjacent gun could be put in accurate line with an enemy, and be fired at will by himself. And, again, the "energy" developed by the rebound of the gun was utilised towards moving or removing it after firing.

Passing next the hill brow, overlooking the Harbour opening, we noticed an elegant article, and so slim of structure, that we might almost lave taken it for a walking-stick-the harmless cane, let us 
suppose, for some gigantic Sir Lucius O’Trigger. This was a powerful small-bore gun-rifle, if I might so call it, for the purpose of picking off and frustrating any kind of vessel that might be sent, in selfsacrifice, to break the submarine line of torpedoes, which, over and above the other defences, guards the passage leading through these Heads to wealthy Melbourne and its surroundings. When I asked next if the night might not be taken advantage of by an enemy who was well piloted, I was shown an electric light apparatus, which lighted the passage as sufficiently for all practical purposes as the sun itself.

Still, I had the weakness to think that half a dozen Russian men-of-war, at the sacrifice, of course, of half their number, might effect an entrance in spite of an opposing militaro-naval Nelson or his ambitious and eager pupil before me, and that a Skobeleff would accept the odds without a moment's hesitation. But, when I learnt that on the opposite head there existecl an even stronger defence, besides further death-spouting apparatus on the Mud Islands and at Williamstown, I felt my courage approaching to what was but too evidently in Major Daniell's mind, namely, the wish that the said Russians would but give him his chance of a deal with them. "Is it not a pity," he said, with a sigh, " that such preparation should all go for nothing?" I did not answer, partly under non-professional excuse, and partly because by this time we had entered his pretty cottage resilence, and I was already busy over some fine Indian tea, which lis elegant young wife harl got rearly for us. There 
was, besides, a restlessly active little boy of his, who made such au incessant din, that, if I had framed any well-balanced reply, its hesitating tones might hardly have been heard.

\section{More of the Defensive.}

I reopened with Major Daniell the subject I had discussed with the Hon. Mr. Fergus, and, to my great satisfaction, with still more complete success. The Major particularly commented on the advance in morule, along the entire line of society, by this military drill, which morale was indeed quite another question, and one superadded for good to that of military defence. If we at home, for instance, could turn out a couple of millions of youths, fairly drilled to the rifle, and with such rifles as are produced nowadays, what country would dream of invading us? That, as it seems to me, is how war is to be ended in this civilised aud multiplying, but still contentious and fighting, world of ours. Our two millions or more would not all be exactly the full soldier, but so far on towards it, that the rest would quickly follow when needed. Gambetta might have saved France in 1570-1, if he could have fallen back upon such half or three-quarter disciplined Frenchmen. But, when the last of the regular arny surrendered at Metz, the fighting materials that remained for Gambetta and Bourbali were, for the sudden needs of the moment, hardly better than school-girls. We mould not need in such case to continue the humiliation of arresting, by our fears, well enough grounded, perhaps, as we now stand, the 
grand want of modern travel progress, the Channel T'unnel.

When I proposed a few years ago to bring this question before the Liberal and Radical Association of my electorate of South Kensington, my friend the Secretary hinted that it was regarded unfaromably by the mass of the electors. This seems to me incredible. If it were a case of a Russian autocracy, using men like machinery without reference to their consent, or of a Napoleon the First, who would have drained his last man for his own grand schemes, one could have understood such feeling.

But, again, this public serrice-for, although, in one view, only youthful recreation, it is real national survice, and may sare defensive.expense in other ways -ought to command some pay, appreciable without being very heary. Such moderate allowances to the youths, if placed to their respective credit in a national fund, might be enough afterwards for a sickness and old-age allowance to the recipient.*

* When Canon Blaclsley, under the auspices of the London Chamber of Commerce, held his interesting public meeting Jately on behalf of some insurance fund for sickness and old age, esprecially amongst the poorer classes, I directed his attention to this new and possible resource towarls his object. $\mathrm{My}$ friend, Mrr. Henry Robson, of the London Stock Exchange, has since supplied me with a striking instance of the successful henefits of military drill in the case of "The Boys' Brigade," an institution which originated in Glasgow so lately as 1883, and which has since spread throughunt England and Scotland, numbering, as it does now (Sept. 1888), 230 companies, 800 officers, and 11,000 hoys. "The original Company is now known as the 'First Glasgow Company' of the lbuys' lirigatde, connecterl with the Free ('ollege ('hurch sabhath sechol society." 
A chief point of interest for the Culonies in this question is, as I have already linted, that if their youth were all thus militarily drilled, such an approximately defensive condition might be considered, so far as the military section of defence was concerned, as the Colonies share under an Empire government.

\section{Indented Head and Victorian Agriculture.}

As we returned to Geelong, we cast a glance over the comparatively flat but rich-looking lands on our right that culminate in Indented Head, a locality famous, in Port Phillip settlement, as the first landing-place of Batman, who, in May 1835, opened Victoria to colonisation by its grand central doorway, after the Henty family had commenced the great work the year before at the western extremity. One of the stations in this part was called Drysdale, in honour of another very early and well-known settler, Miss Drysdale, an Ediuburgh lady, who, with a somerwhat masculine mind, had found no difficulty in getting through life and business, even in its rather rough and miscellaneous quality, in a new settlement, without the aid and comfort of a husband.

Some soils and climes hereabout are remarkable for special products. I have spoken of peas at Lancefield, and hops about Lilydale. Here it was onions, of which we heard of prodigious crops. But Portarlington and Indented Head, generally, are one entire nest of successful agriculture. Walking down to Melbourne Wharf the morning after my arrival, 
I noticed countless great bags and casks of vegetables - potatoes, carrots, parsnips, onions, leeks, cauliflowers, all of the most portentous size and quality, which on inquiry I found had just been landed by a vessel from Portarlington. For potatoes, the prize place, as I was told when there, was Nelson in New Zealand, where, incredible as it may seem, crops have been got of 18 to 22 tons per acre, or more than double of what would be called a good crop anywhere else. Returning to the Portarlington case, the wonder is increased by the fact of the still early season, for the time I speak of was the first day of August, or only the very dawn of the Australian spring.

We had some friends at Geelong, Mrs. Scott, her husband, and their large fanily, she herself being a daughter of my old friend and early fellow colonist, Mr. George Sinclair Brodie. She was one of my favourites in her very juvenile years, somewhit over a quarter of a century ago, and was then certainly very charming. The question now was whether this charm had been maintained, possibly even increased since. This question was all the more delicate, as more than one of her daughtiter's already threatened their mother, however unconsciously, with a disloyal rivalry. I fell back upon Byron, who, as we all know, pronounced school-girl juvenility to be mere "bread and butter" in love's food, and sent his hero in preference to the matured siren. My matronly friend had now nine children, no less, inchuding five fair daughters. As I had myself, on the contrary, only a small family to boast 
of, I could assure her that these pleasant and lively surroundings were more precinus than land or gold, or even the fullest assurance of her own still surviving superiorities.

\section{Geelong to Ballarat.}

Passing out of Geelong, we went on, for half of the way to Ballarat, oree a flat, monotonous country. the only redeeming feature of which was its pastomal greenness. Victoria had this season sufficient rains to cover all the comitry with rerdure. while all the neighhouring (olonies han been suliject more or less to drought. After this, however, the country improved as we went on, with hill and dale, and pretty ristas of grass-carpeted open forest. It Lal Lal station and hotel, howerer, we could get no view of the beautiful falls, fairly full of water as they were at that time, and in whose vicinity my old friend, the late Mr. Peter Inglis, had lis sheep-run from rery early times. Ifomnt Buninyong rose finely on our left, and soon after we entered Ballarat East, passing on, however, to the more considerable Isallarat West, only a mile further.

\section{Ballarat.}

This is the second city of its Colony. It is, we suppose, a city by right, as at Home, of its Anglican bishop. Any way as to that, it is quite a magnificent place, with wide and handsome streets, already tree-planted, and even in double rows in not a few cases. Sturt Street, the principal, is hardly 
second in effect, as a whole at least, to any street in Australasia, with imposing structures of banks, insurance, and other institutions, and its grand breadth as well as length. The botanical gardens are worth looking at. A pretty lake, with fine houses, gardens, and public plantatioris around it, was in my time a solitary shallow swamp, orergrown with reeds and rushes, although otherwise a pretty enough object to diversify the almost empty country of that early day.

I recalled a visit I paid to the site and scene of Ballarat exactly thirty-seven years before, when on the 3rd of October, 1851, just twelve days after the discovery of gold there, I arrived on horseback, as there was no other mode of conveyance in those days. I witnessed then a marvellous and noisy spectacle, people of all classes having arrived, many of them with black coats, spectacles and eye-glasses, as though just from comting-houses or law offices. Thousands were already there, and so much gold was being got, under my own eyes, chiefly from an upper drift-bed called the blue clay, that I estimated the quantity at $£ 10,000$ per day. This estimate was long deemed incredible at Melbourne, for its addition would at once quadruple the Colony's whole export amount of a million sterling for the preceding year. But Tictorians, hardly yet realising their great position, had soon to strain much higher than even that, when, in the following year (15.52), there was an estimated gold production of no less than fifteen millions.

We had but seven hours to devote to great golden 
Ballarat, so we hired a cal, and went at once to work, after depositing some effects at Craig's Ilotel, and strengthening ourselves with a good luncheon. Our friends, the Rev. Mr. Caims, Preslyterim clergyman, and Mr. Wm. G. McCrae, whom I hawl known from almost infancy, accompanied 11s, and the former brought in addition one of his elders, Mr. Inuray, President of the local Old Colonists" Association, to our help. Another old fricul, Mrr. Wanliss, whose acquaintance dates from the Balli: rat riot and the consequent Gold Commissiun of 15.it-5, was unfortumately absent in Queensland, but we satw Mrs. Wanliss and family at their pleasant residence a little outside of the city.

Mr. Murray took us chiefly in hand. We hard first a drive round "the Lake," which I remembererl, as already said, as a shallow swamp, half filled with reeds and weeds, and with such crowds of leeches that, when I waded into it with my bare feet on the occasion of my long back previous risit, I had to make a precipitate retreat to the land. But now the reeds or rushes have been mostly cleared, the bounds extended, and the water deepened, so that during the season there are several passenger steamers and frequent regatta races. The public gardens had some fine Italian statuary, presented hy a wealthy and generous citizen.

\section{A Ballarat Gold Mine.}

But we must needs see also some of the great gold mining, and Mr. Murray selected, among the many mines, one in particular with which he hant, in a 
business ray, something to do. It ras within the city bounds, was in fact, so to say, one of the members or occupants of one of the streets, and it was not at all singular in that respect, as the peculiar sort of wooden chimney-looking superstructure here and there elsewhere indicater. The depth was 1500 feet, and our danghter, who has no want of curiosity and the requisite courage in such adventure, expressed the wish to make the descent. And, if she went, I must, of course. go with her. Approaching the edge, and looking down the misty darkness of the shaft, a hot steam came up almost with a rush against our faces. Even this did not divert our purpose, as, where others lived daily for hours together, we conld easily, as we inferred, manage for minutes. But when we heard of the wet and dirt, and that a digger's enveloping would be indispensable, we "caved in" upon the matter, and remained where we were. Forthwith a couple of men, who had been waiting our decision, and were to have accompanied us, making the maximum party of a rather closely packed four, entered the box and began a quick descent. When we returned three minutes after, they were still twirling down, and with a seeming rapidity which made me wonder that they had not yet got to the bottom. But we were told that this requires as much as three and a half minutes; so, altogether, I was not sorry to have given the go-hy to this auriferous Tartarus.

We next followed the process of the "wash dirt," as it came up from this rast depth. I understood it was the quarty reef; but there was little appearance 
of the sort of thing our fincy paints to be bright and cleanly quartz. It was a mixture of stones and mul. which, after draining a little, was tumbled into a great hopper, whence it reached countless little stampers, which with terrific noise reduced it all to dust, so as to enable the quicksilver to make, by its superior attraction, an amalgam of the gold. The proportion of gold at this mine was about one ounce to the ton of material, a proportion which "paid " very well. There are some other mines in Victoria considerably deeper than this one, but we understood that it was the deepest in Ballarat. The deepest of all as yet in the Colony was at Sindhurst-between 2200 and 2300 feet. I compared this rery adranced golddigging process with that at the time of my first risit to this place in 1851, when digging was hardly a fortnight old, when the blue clay, some ten to twenty feet below the surface, was only just tapped, and liad not even been bottomed, and when diggings were simply great open holes in the clay. And yet withal more gold per man was got then than now.

\section{Mayor and Town Hall.}

Te concluded our day by a call upon His Worship the Mayor, whose very creditable palace, or 'Town Hall, made no small appearance in the main street. But, as this would be past business lours, his friend Mr. Murray "telephoned" his Worship to remain at his post for his distinguished company. And this we found him. Mr. Macdonald, the Mayor, was Scotch; so were Mr. Murray, Mr. 
McCrae, and ourselves, while Mr. Caims was Scotch-Irish. Te naturally, therefore, descanted complacently on the supremacy of the Scotch element in these Colonies, and were easily assured that it greatly contributed to their prosperity. The Mayor and I having got into an absorbing discussion about early Ballarat, Mr. Murray, who was a bit of a wag, remarked, in a rather loud under-tone, that it was regrettable that the company were teetotal, as otherwise, no cloulut, $\mathrm{His}$ Worship's hospitalities would have been more apparent. His Worship penitentially jumped to his feet, and within the next half minute the table was spread with a dozen varieties of "refreshment," home and imported. We solected by preference some fairly good Tictorian wine, and drank prosperity to our host and his great Ballarat. 


\section{$(259)$}

\section{SECTION XXVII.}

A VISIT TO MR. ELLERY AND 'THE MELBOURNE

OISSERVATORY.

I HaD never happened to see the heavens through any unusually great telescope, and this was one of the pleasures I promised myself in revisiting Melbourne. Accordingly I kept a look-out for Mr. Ellery. Having a lingering idea that his place might still be the old Flag Staff Hill, which had the only "Observatory" of its kind in my day, that namely where arriving and departing shipping were observed, I started, a morning or two after my arrival, on my usual preprandial walk, about eight o'clock A.x., in order, amongst other things, to show him what activity still remained to the old sons of the effete mother at the other end of the earth. But I found that there had been long ago a removal of observation to the Government grounds on the other side of the Yarra, near the Governor's residence, so I had to wait for another leisure interval.

Mr. Ellery is an unpretending-looking man, rather less than average height, and very frank and approachable, which is assuring when you encounter a leading astronomer. But, although by profession he lives in the region of the gools, he has all the curiosity or other desire which these upper classes of the ancient classic times had to look in at the haunts of ordinary mankind, for I first met him at one of 
the Government balls, where he appeared in earthly uniform, as if he fully belonged to ourselves. He readily promised to transport me beyond the clouds and to display the wonders of "the spheres" on any evening I might fix. I was for long after mable to break off from a constant succession of earthly ties, but at last, resolute by despair, I fixed the night before my final leave, and made all else "go to the wall" for that occasion. Our partr, starting after dark, in a cab, had some difficulty in finding, first the anthorised entrance from the main or St. Kilda Road, and next the observatory offices, situated in the large open surrounding. Our cabby knew only about the earth, nor very accurately about that, in this section of it leading to the heavens. At length, however, we found Mr. Ellery and his assistant, and we were soon devoutly gazing upon the great telescope.

There were two great instruments, and the one before us was the lesser. The other, which was needed chiefly for very faint remote oljects, was then under repair, its great reflectors requiring a very long burnishing. So we could not see that one. But the other was also a grand instrument. Alongside of it was a comparatively small telescope, as a ready pointer or finder, like a pilot fish to a shark. 'This one, hower re, was only by comparison small, for the moon, to which we first turned, was large and beantifully d stinct through it. But, turning now to the same object through the larger glass, we salw an imm nse area, with some of the lunar craters atong the extse of the light very distinct, the moon 
leing about one-third full. In the very centre vi.w was Plato, one of the largest and most perfect, with its central sun-lighted sumnit, and the dark crater surrounding. The sun glinter also upon some lofty peaks outside along the light line.

We would have liked much to have seen Mars, with the wonders taking place of late there. But he was now so far from his nearest, that it was of no use wasting time over him. Jupiter also was batly placed, being then too low upon the horizon, and for some other reasons we could not see Saturn. But we found some amends by a sight of our nearest star-neighbour, a C'entunur, a star having a companion, but at relatively so small a distance that only a very powerful glass can show the separation. The "pilot" could not do this, hut the greater glass did it most distinctly.

Now I felt I was on the track to get astronomic information in a much simpler and directer way than by searching through all the pages and mathematics of Proctor for just the points one was at the moment interested in. There was an incessint and to the eye most painful quirering in the above double star's aspect, which seemenl hopeless for any purposes of accuracy. But for this we should no doubt have seen quite distinctly two brilliant small suns, one of them, however, very much brighter than the other. And yet there was no visible disc in either case, such as the planets show, as no telescope hitherto has been of power sufficient to show this in even our nearest star neighlours. This quivering, explained Mr. Ellery, is one of the liniting causes 
of our vision, for we magnify the air's vibrations with the magnified object. This vibration, he went on to say, greatly disappeared as the observer ascended high into the air, as at the United States Obstrvatory, 4000 feet high in the Rocky Mountains; and still more, as Piazzi Smyth showed, from the top of 'Teneriffe. If we could place ourselves entirely outside our quivering atmosphere, our telescopic linit would be greatly extended. We must, therefore, contrive to be able to climb to, and live and rork in, the Himalaya summits, where we shall be in a comparatively tremorless thinness of medium, and be possibly kept alive by compressed air within an air-tight surrounding: .

I fieely exercised my right to ask questions. What was to prevent an indefinite magnifying of photographs of the moon, of Mars, \&c.? But there is the concurrently magnified surface, like the magnified air tremors, and so we are stopped as much as if we tried to sketch a picture upon a surface of sea or river boulders. 'The surface then is all that is wanted. Trell, suppose we threw an instantaneous photo upon the crown of a soap bubble, and as instantaneously brought it under one of Sam Weller's "double million magnifying gas microscopes of liextra power," we might see, actually at work, some of those mysterions people of Mars, whom Proctor and other's conjecture to be ligging fiftcen-mile-wide canals, and who of late, with marvellous rapidity, but for purposes we can in 110 way imagine, have cut some snch breadth of patsirges through the snow cap? of one of their poles. Pussibly, by a slight alteration 
of composition, we may induce the soap bubble to live for a minute instead of a second, so as to show things more leisurely. Proctor seemed to think that men in Mars might be tall and powerful in some proportion to the reduced gravity, so that these large works might only be proportionate. Possibly these Marsians, in sheer wantonness of strength, seek something adequate to do.

I asked Mr. Ellery if he did not think Venus to be more like our Earth under all circumstances than Mars, the only difficulty being that we could not see her surface for her clouds. But he seemed decidedly of opinion that Venus, owing to her greater proximity to the sun, had not yet conled down to a solidity of surface sufficient for life, or at least human life. That suggests curious reflection as to Mars, for, by his much earlier cooling, he may have been in human occupation for countless years before our earth. But at our present pace of scientific progress, now that we have at last got into the Baconian-Newtonian method of adrance, a mere thousand years, if not, indeed, very much less time, may see us sending, perhaps, electric or lightborne messages to the planets. What, then, has Mars been about all this time? But who knows whether, after all, he may not have been, for the last million or so of years, sending us messages which have merely passed, all undetected, into our meteorology, to the wonder of our adranced brother planet at our slumbering barbarism? Or, again, may the case be that Mars, with his largely absorbed seas and thin ranishing air, is already approaching the 
condition of our lifeless moon, and has ceased to possess human beings at least, whatever else of life may still linger there?

Mr. Ellery next showed us an object which, under even powerful telescopes, seemed only a faint and rather mazy star, but which was now distinctly seen to be a mass of countless stars. Then we looked at a faint nebula, and one or two other objects. After which came a discussion on the spiders of the threeply thread, alluded to by Mr. Froude as so much more suitable than the more usual seven-ply thread. These three-ply spiders, after having been brought, years ago, purposely to the place, have bred so vigorously, as to be already a nuisance. We had, however, a good proof of the important bearing of all this fine-thread business. Looking through the smaller glass, I noticed that the aperture was rectangularly crossed by lines of the thickness of grocer's ordinary twine. Inquiring of Mr. Ellery what this meant, he said that it was the three-ply spider's thread, used to divide accurately the area. The unravelling of three-ply was, of course, less difficult than that of the seven-ply. What was only twine thickness in the smaller telescope must approach that of a ship's cable in the larger. 


\section{$(265)$}

\section{SECTION XXVIII.}

\section{A MUCH-NEEDED REFORM.}

An independent reference for valuations of Culonicl interests brought upon the London market.

Mr last day in Melbourne was taken up by several duties of more or less importance, but none of them so important as that which, in its novelty, for want of better, I have described as heads this Section. By appointment I met four of Melbourne's chief men in her mercantile, political, and social world. I had previously interested these gentlemen in the large question I have above foreshadowed. It had come repeatedly before me in my Australasian tour, just then terminating. They, too, had concurrently expressed their interest in the subject, and at last their willingness to second my endeavours to provide some remedy for what had been, until then, a very great evil and hindrance throughout Australasia.

In short, it had long been practically impossible to place even the soundest interests upon the London market, owing to the systematic fraud in valuations -for it can have no other name-with whicli, in the absence of any known possible check, the capitalist and investor had been dealt with in that market. I give in the Appendix* two illustrative cases which, although only samples of many and 
perhaps by no means the worst, happened to come in my own way: the one showing the unscrupulous license taken in the matter of valuation; the other the hardly less unscrupulous commissions or promotion charges made against those who, in the colonies, try to raise funds in Isondon upon their local interests.

'I'he direction which struck me as best towards a remedy was the establishment in London of some - great Trust, of conspicuous strength and responsibility, which, besides the usual agency, loaning and other business of an ordinary trust, would act as a perfectly independent reference as to valuations of interests sent for negrotiation to the London market. The valuation should be supplied to those acting for the Home investor. The Trust must not come in contact, at least as dependent agent or e'mpluye', with any of these Colonial interests. The 'Trust's Colonial Branches must gatler as it best can, lut always with perfect independence, its local information on values. It will receive its fee or commission for its services, no small one in many or most cases, solely from those who have been protected and benefited.

The business that almost at once opened out in this direction appeared to me all but incalculable. Lands, mines, trades, in comntless array, seem all awaiting a development which depends mainly on London capital, as the comparatively small fund of the Colonies seems always otherwise engaged.

'Then the 'Trust had best be of conspicuously large fonndation-l,e in fact the king complany of its kinkl. 
There is no want of ronm for such a Trust. At every step through these Colonies I was successively reminded of the want of rearly means. Orer-railway construction and expenditure, for the time, in New Zealand, did not in the least help, for instance, the mining development, but rather imporerisherl its interests all romd, by drawing away people and money to other and premature interests. For did an enormonsly rich mine, like Mount Morgan, in Queensland, for example, give immediate liclp, as those lucky speculators who were ever clearing ont and taking their gains with them, would, in most cases, withdraw much more of the Culony's lifeblood than the mine had as yet given it. The Trust may not have much to do in advancing on such mines, but the mining towns' lands, and the lauds of the Colony generally, adranced in value by mineral levelopment, present a safe, wide, and ever-extending field.

There is ansther point, second only to the first in mining, importance. The uncertainty of mining results is of course proverbial. But if there were some system of assorting these individual uncertainties, so as to give the adrantage of an arelage over some consideratile number, everyone can ses what greater certainty of result miglit at once be attained.

This step would be advantageous and desirable also on other and quite different gromels, sufticient alrearly as these just stated may be regarded. The London market begins to be orerwhelmed with an almost countless crowd of small indivi- 
dual mining concerns, so small as to render hopeless a Stock Exchange quotation, so small also as to hare hardly negotiable quality; and thus, for both reasons, always aroided by the facilitating jobber or dealer of the market, who, if he effects a purchase, or chances a sale, in such slow directions, can never tell when he may clear his operation. This proposed areraging into substantial totals would not only make a steady dividend, and probably also a large one, all but certain, but the stocks would also be quoted, and be as readily negotiable as any others.

With the urgency alike of necessity and advantage, a modus opercindi would doubtless arise in this last case. But it is rather a delicate and difficult matter if delayed until after concerns, even the minutest and least promising, have subsided into the definitive forms of officiate and directorate. MIy late most intimate and pleasint friend, Mr. A. L. Elder, equally well known and well esteemed, used to amuse me, times without number, by the unfailing humour of his story of "the Seats." But the song of "the Seat" was not at all of the same kind as Hood's sad, sad "Song of the Shirt." Still, it had its own useful moral as well.

A certain nameless concern had, after due trial, not by any means done as well as might have been wished, and the proposition was to merge it into another which had done much better. The terms were quite unexceptionally good to the weaker vessel, so that the arrangement at first ran merrily. Still, something ever blocked the final execution, and 
at last a black and white inquiry of the impatient shareholders brought out the block of "the seats." The Directors were waiting to know what was to lie given them for throwing up their seats? When my friend first told me of the pending difficulty; I suggested, entirely as a specially benevolent amims. curice, that as the seats were only yearly, the matter could hardly be worth quarrelling about. "Oh, dear, no!" he responded, "the arts of re-election being in view, when my comrades cast their eyes upon their seats, the venerable image of Eternity rises before them." The matter was compromised somehow; but that never stopped the joke, which in fact was far too good to die. So we see that amalgamations, to have ficir and free chance, must be begun prior to "the seat" stage.

Thus I had the satisfaction to leave behind me at Melbourne a Board contingently complete for the new Trust, and consisting rather in quality than quantity. I had made just an initiation in the sane direction in Brisluane, where, howerer, further progress was for the time stopped, from the ton evident fact that every leading or likely resident seemed, one more than another, up to the eyes in the mining or other enterprises of the time. In Sydney I had not time to open the matter at all, leaving that, as well as the rest, under the propored headship of Melbourne. Having sketched out the constitution of the Trust, as it would probally be brought out in London on my return, I left Australia with the understanding that a simple telegram, intimating a certain bank credit, would 
tell that the Trust was in existence, and that the Melbourne Board's duties commenced at once. This is our mode nowadays of jumping the distance of the earth's diameter, as though but a next door's remove. 


\section{$(2 \pi 1)$}

\section{SECTION XXIX.}

MELBOURNE TO ADELAIDE BY RAIL.

At last had the time arrived when we must quit my dear old home Melbourne, made still dearer by the kind reception we had everywhere met with. We had preferently given to Melbourne and Tictoria by far the longest attentions, seeing that those two visits made up an entire month, or not much short of the time we had left for all the rest of Australasia. We had to time our departure by the sailing. of the Steamship "Orizaba," in which we hat, during our previons visit here, secured our Home passage. This fine ressel, starting from Sydney, vin Melbomme, for Adelaide, was to leave the latter place on the 15th Oetober, with the expectation of landing us at Plymonth about the 22nd November. We wished much to see Adelaide, and what more was possible of the Colony of South Australia, before leaving the pleasant sunny south; and a hospitable invitation from Sir Thomas Elder enabled us to do so under the most agreeable anspices. So we fixed the 11 th of October for leaving Melbourne, in order that we might liave, at any rate, three days to devote to the sister capital and its surroundings.

\section{A Farewell Address.}

There was yet, for me, one most important business before we started. I was to have one more meeting, just a few hours before departure, with the 
Nelbourne Chamber of Commerce, whose members proposed to give me a farewell address. A copy of the proposed address had been previously sent to me, in order that I might be ready with a suitable reply. I was glad of the opportunity, as I had not a few interesting subjects to speak about after my many perambulations. The subject that appeared to me of the most pressing and immediate importance was that of the Trust which I have just discussed in the preceding section, and I had to thank the President, and some others of the members, for some good help which they had given me towards maturing my proposed plan.

\section{The Start for Adelaide.}

Our train to Adelaide, which was the mail or express, left Melbourne at 4 P.x., so that for the three hours of daylight we passed over only the old ground already described, and entered Ballarat once more about 7 P.x., and once more we met there, for the ferw minutes' stay, some of our friends of the preceding visit.

We regretted that much fine and most interesting country must be passed in the night, and this was especially regrettable to myself, as I had traversed much of it many year's before, and would have been pleased with the endless succession of surprises at its progress since. However, there was no help for it, and so we called for our bed accommodations, and were soon after in the most comfortable condition that I have ever experienced in railway night travelling. We had already expected as much as 
this, because we had been told that the Melbourne and Adelaide line had reached the head position in this respect.

\section{The Mallee Scrub.}

Text morning by daylight I looked out of $\mathrm{my}$ window, as Noah might lave done from his Ark, upon a rast level, horizonless expanse, only that it was not of the waters of the Flood, lut of the very driest of land. In short we were in the rast Mallee Scrub, so extensive in North-west Victoria and the adjacent part of South Australia. Te had left the Tictorian boundary, at Servicetown on the one side, and Bordertown on the other, far behind us, and were already half-way to the River. Inurray, and the station there, called Murray Brilge, where we were promised a $T$ o'clock breakfast. The Mallee is a dwarf species of gum tree, and forms at times, with various other bushes or shrubs and flowers, a tangled regetation so thick as not to be easily permeal,le to the traveller. The soil beneath this growth is usually little letter than pure sand. It las no grass, properly speaking, but in its stead some green rushlooking tufts, more pleasant to our eyes, I fear, than nourishing to any quadrupeds placed before it. The scene was not without beauty of its lind, for there was a pleasing diversity of bright green bushes, and a profusion of variously coloured flowers, most of them of the heath character, with their pink or white bells. Almost instantly, however, we would dash at times into a complete change of soil and regetation. Green grass surrounded ns, sheep 
were feeding in great numbers about, and a small squatting homestead completed the new scene. But no live humanity were yet about at that early hour. Anon, we were in yet another variety of country, where the soil was again poorer than this last, but yet covered, although only thinly, with the pleasant grass, and with the rariety, pleasant also in no small degree, of an open forest of gum and "she-oak" trees. And then once more we plunged into the Mallee.

\section{The Rirer Murray, the Australian Mississippi.}

All this time the country was mostly quite flat; but, as we approached the river Murray, there was a general improrement, alike in soil and scenery. The bridge hove in sight, and the Mississippi of Australia, in a course of grand sweeps and intermittent expansions of bed, ran before us. The bridge sought of course, as at Albury, the narrowest and most practicable part, but above us were some of the reedy expansions, where cattle rerel in the spring of the year, greedily derouring the sweet young growth, and not seldom fatally gorging themselves with it. Australia's Mississippi, however, is, after all, a comparatively small one, although a great triton amongst Australian minnows. It is one of the few Australian rivers that have never been known to cease running. Indeed, only the rivers from the Gipps Land Alps, where the Murray rises, have this distinction. Even its long northern tributary, the Darling, much longer in its course, in fact, than the main stream of the Murray itself, 
has repentedly failed of running water in dry years.

The Murray Bridge is a wooden structure, solid indeed of its kind, but the Railway Station is built of stone, and there are some few other stone houses mixed with the commoner wooden structures-all forming the commencement of what, in ten years' time, may be a large and busy interior emporium. Two young school-girls, with sun-browned laughing faces and lint-white locks, paced the station platform, amused with the novelty of the arriving passengers. I asked them, "Did they fish sometimes in the Murray?" "Tes," "Catch Murray cod?" "Tes." "Tery lig at times and more than they could lift?" "Yes." Indeed, as we were told at Albury, they grow to a hundredweight; but, mlike our salmon, which is best at its biggest, the cod gets coarse at this stage, and is choicest for cating at only five to six pounds.

Onwards from the Murray to Adelaide the country was almost throughout one succession of fairly good pasturage, with hill and dale in a pleasing rariety. I was agreealbly disappointed, having un idea that there was so much good land about delaide. In fact, we Melbourne and Victoria people had, in my day at least, been in the habit of very much underrating our sister, so that, as I hare presently to tell, we had to get ourselves very considerably undeceived. The passed Nairne, a pretty township founded by the Smillie family, who were early settlers from Leith; then Mount Lofty and the Glen Osmond Hills, and a few minutes more sent us into Adelaide. 


\section{SECTION XXX.}

ADELAIDE AND SOUTH AUSTRALIA.

$\mathrm{Br}$ early forenoon we entered Adelaide. Our friend Sir Thomas Elder was at the station to meet us. We were glad to see him well again, for we heard that he had been seriously ill some months before. His life is valuable to the Colony, alike for his prosperous enterprise and the generous help he gires its institutions. He arrived in 18504, and has built up a great fortune since; but the senior and founder of the leading mercantile house of the Elders there, my late intimate, and most valued friend, Alexander Lang Elder, arrived so early as 1838, almost amongst the first. The house, still in the first position, is now Elder, Smith, \& Company, Limited. Sir Thomas drove us at once to Birksgate, his beautiful residence on the western slope of the Glen Osmond Hills, four miles east of Adelaide, where we revelled in everything that man can want or desire, along with, at this springtime of the year at least, the most paradisaic of climates.

There is only one drawback, but a serious one, to such fine places, namely, that you must be proportionately unwilling to quit them at "the call of God" and failing nature. It is then, as it seems to me, that the poorer folks of a harder life have in 
turn their triumph, or, as it were, their counterbalancing Nemesis. Solon, or some other of the seven wiseacres of old time, has said that the end is the thing to judge the happiness by, because, standing on the last ledge, all the earthly good before has passed away, and is not of the least benefit to us any longer. Sir Thomas, howerer, had one saring trouble; he confessed that he did not at all lilie the full South Australian summer. If therefore his call come to him at this obnoxious season, he may happily pair off with ordinary mortals on at less disadvantageous comparison than might have been otherwise expected.

\section{Beautiful Adelaide.}

I had heard of the great beauty as well as the considerable extent of the Adelaide of to-day. My recollection of it ou a previous visit, as far back as 1853, was not particularly farouralile. But, prepared as I was to find now something worth seeing, I found that I had formed an idea much short of the reality. The streets wide, beautifully kept, full of great and handsome buildings, formeil to me, on the whole, the most tasteful urban spectacle I had yet witnessed in Australasia. King Wrilliam Street was superior in this respect to the chief streets of Melbourne or Sydney, while the cross streets also, as Governor Robinson remarked to me, had their beauty scenically enbanced by the pretty vista of green hills at their extremity. Of course, I do not compare general dimensions 
of structures, and the scale and visible tide of business. Adelaide, although no small place, with its 150,000 of population in town and conjoined suburls, is greatly behind Sydney with 350,000 , and Melboume with 400,000 people. Adelaide las still other beauties; for within the city are Government House, with its pretty grounds, elegant and well-stocked botanical and zoological gardens, and such a highly artistic disposition of the originally unpretending little Torrens Creek, traversing the city, as to reproduce a Serpentine and a Hyde Park, more beautiful, if less extended, than their northern prototypes.

Adelaide's beauty did not save her, and the Colony of which she is the capital, from cruelly bad times of late years. First a severe drought befell her, in common, no doubt, if that were to her comfort, with her sister Colonies; and this was hardly over by a couple of years, when she was smitten "hip and thigh" by almost unprecedented depression in the value in the London market of her three great staples, wool, cereals, and copper. There was consequently a terrible tumble in all colonial values, with the usual losing results to individuals and firms. But there is a bottom at last to everything of that kind, and Australia in particular has shown herself wonderfully elastic to rise again once the bottom has been reached. We found Adelaide recovering her cheerfulness, under the feeling that her corner had been turned.

'The Colony has long taken quite a lead in winemaking, nutil surpasserl the last year or two by 
Victoria. But the progress is still good, for while in 1887 there were 510,000 gallons made, in 1888 the quantity reached 708,000 gallons. Wheatgrowing and flour-making have also been conspicuous; there being now eighty - five flour mills of $195 \mathrm{~L}$ horse power, and employing 614 hands. The customers for this flour, besides the adjacent Colonies and the mother country, include Hong Kong, China, and other remote markets.

After calling upon the Governor, Sir William Robinson, tall, middle-aged, intelligent, who frankly, and with critical appreciation, discussed the Colony with me, I passed to the Premier and Treasurer, Mr. Playford, to whom, as to the other Australasian Premiers, I had given myself a mission, the chief object of which was to endeavour to persuade them to leave off giving us 4 per cent. interest for their loans, or even $3 \frac{1}{2}$, and to come down at once to 3 per cent. But it is astonishing how difficult this is, owing, let us suppose, to habit, which is at least a more probable cause than any generously loyal desire to give lenders at home more interest even than they would be satisfied to take. There was also another contingency. Their own voters, and the public generally, had a strong objection to receiving the proceeds of loans sold at a discount. This was, in fact, Mr. Playford's chief obstacle and difficulty. $\mathrm{He}$ is a man of large head and physique, like our friend in common, Sir Arthur Blyth, the London Agent-General, who had enjoined upon me to see him and discuss with him the finance question. Both of these high func- 
tionaries are men of a presence-such as naturally take the political or social lead. The discussion, I think, tended to some result, and Sir Arthur, in his Agent-General's capacity, is likely to be concerned in it ere long. 


\section{$(2 \times 1)$}

\section{SEC'IION XXXI.}

THE AUSTRALIAN TRANSCONTINENTAL RAILWAY.

Mr interest in the public objects of the Colony centred chiefly in this great railway, which has already been courageously begun at either extremity, and is still proceeding. South Australia is still inadequately strong for so costly a business. Twelve hundred miles of intermediate passage still lie non-railed, and the minimum cost to finish has been put at eight millions, although more likely to be two, three, or even four millions more. South Australia, whose colonist, MIcDouall Stuart, first crossed from south to north within what is now her own territory to the sea, had the ambition to claim and govern the entire through area. Bourke and Wills, from Melbourne, had previously crossed to the eastwards, reaching the tidal salt water at the mouth of one of the rivers at the head of the Gulf of Carpentaria, but not seeing the actual ocean.

South Australia's ambition to secure all of this through area was most readily gratified by the Home Government, and considerably more honour than profit is understood to have as yet come to South Australia in consequence. One of the antieconomic honours which have fallen to her in consequence has been the duty of making this great trans-Australian railway, by virtue of the fact of its being entirely within the later bounds of South 
Australian territory. But in other and general respects the line is quite as much a Victorian interest. Tasmania is also interested. New South Wales is so also, but in a less degree, as she partially sways towards Queensland, which is already contemplating another line, not perhaps in the exact sense of a rival, round by the eastern coasts. Thus more than one of the other colonies might righteously help their sister in her struggle.

The question whether this great line should be gone on with to completion occupied much attention in Adelaide, and was the cause of strong divergence of opinion. Some of the leading merchants decried it absolutely. It will drag the Colony into insolvency, said Mr. Barr Smith. It leads nowhere, and its last chance in the north is taken away by exclusion of the Chinaman. His relative, Sir Thomas Elder, was equally opposed to the small financial strength of the Colony being pitted against such a job, but he would willingly see the railway made, with all its as yet unknowable chances, if that could be done by substantial help from outside. The agency most surely attainable seemed that of a bargain between the Home capitalists who would make the line, and the Colony, which would give an estimated equivalent in land. I am rather against that plau, because such lands, which may have no realisable value for fifteen or twenty years, go for hardly any pecuniary consideration to a capitalist, looking, as he mainly does, of course, for inmediate dividends. Thus the Colony's great estate is practically thrown away. It seems to me always 
better for the Australian Government to make the lines themselves as cheaply as may be, and reserve the sale of their great landed estate for a better time later on.

My own most decided riew is in accordance with Sir Thomas Elder's. The mineral developments of Australia, hardly as yet even one-tenth part slightly "prospected," seem practically boundless, and the railway may well be completed, if only upon the probabilities in this sole direction. Australia has proved curiously compensatory in the qualities of its soil. With the richer qualities for agriculture, and the lighter for pasture, the sterile, of which there is no small proportion, give the inspiration of the mineral, for, wherever we see granitic or quartzy sterility, we instinctively look for the precious metals.

Besides this leading consideration, a railway through the Australian centre, by facilitating the conveyance of artesian apparatus, might sensibly ameliorate the Australian climate over the central flats and general depression of that very peculiarly constituted country. This railway, then, is a high Australasian interest, and indeed an interest eveu wider still; and it would be pitiful, in these days of the Empire's boundless financial power, to suffer the grand possibilities of such a line to be delayed. I hardly look for much use of it, at first at least, as a direct through-passage route from Europe to South Eastern Australia, for if we are to have, as we soon must, the speed of twenty knots an hour, which is already established between Liverpool and New York, 
I expect that the old Cape route would be apt to reassert itself in preference to so much hot landtravel. But no doubt, when, early next century, there is an unbroken continuity of a fast express between London and Singapore, the Australian Transcontinental will have its full chance.

\section{The Chinese and the Culoured Labour Question in} connection with this Railway.

The Chinese question, and the "coloured labour" question generally, are no doubt also a large part of the general case; and, as the Chinese question must be faced and discussed by any one who deals with Australian socio-economics, I am disposed to take it lere once for all. The case of the Chinese is quite peculiar. They are not bad colonists; quite the reverse, generally speaking. But every one, whose thoughts go below the surface, sees or infers that from their readily adaptive qualities, as regards all the various circumstances of human life, backed by the ready mobility and countless multitude of their race, they will, if freely admitted, and perhaps far sooner than we can dream of, possess and denationalise Australasia. Australians will be too late if they do not at once begin their restrictions. Later on, when the Chinese may stream in by the million, we cannot, actuated, as we must hope we are, by civilisation and religion, seize the sword and treat them as we might do a pestilence of locusts. But for the stupid foreign Tartar despotism, which represses the readily self-adapting and trading 
Chinaman, China would be, in this swarming exodus, far more threatening than she eren now is. But the Tartars may be cleared out some day. and soon thereafter China, with her humberls of millions, may roam far and wide orer the world, to the considerable disturbance perhaps of other people some generations hence. The Chinese authorities should be simply told that Anstralia has the same objection to a million Chinese that they themselves would have to a hundred millions of a European influx, for such are the relative proportions. All treaties must give way to common-sense considerations of this kind.

The other coloured races, if indeed the grand old historical Chinaman ought to be gathered indiscriminately amongst this human miscellany, present $n$ difficulty whaterer. Ther, the Coolies, Malars, Kanakas, will make no effort, either consciously or uncouscionsly, to denationalise us. Generally speaking, they, contrary to Chinese tendencies, will not even go southwirds out of their farourite tropics, and out of the association, respectively, of their own races. They may, therefore, be freely admitted, to develop, to the fullest possible, olir tropical territory.

Our tropical colonies, like the case of the Chinese, form indeed a special question. The European cannot work there as he can in his own temperate latitudes, or, if he persists in doing so, he early finishes himself and deteriorates the race he leaves behind him. Consequently there is for our tropical possessions either dark labour progress or none at all. 
Such Colonies have indeed only a destiny of the second order before them. But that is not an altogether unworthy destiny, and it may, through our colonisation, become one much higher than any other available to the races in question.

\section{The Mode of Gorernment of Tropical Colonies.}

The only other question in this connection concerns the government of such territories. With the few of the superior race, and the mass of the inferior, while the former exist at all, they must do so as masters. What follows is only too well known, so much so as to cause incurable suspicion where the mastery is practically given to the superior few by the concession of constitutional government. Such a gorernment, in such circumstances, would, by its instincts, institute a practical slarery, and even if it could rirtuously abstain from this result, it would be ever suspected, and therefore more or less restricted, to the injury of the country's economic interests. Such territories, then, should become, or should remain, Crown Colonies. In this suspicion-disarming form, the tropical sections of our Colonies would march forward unimpeded to the maximum of the prosperity possible to their circumstances.

There may be difficulties in "reducing," so to say, constitutionally free territory to Crown Colony conditions. But to me the difference of political conditions in such cases appears hardly more than mere sentiment. If our Australasian group is to be ferderated into one general Colonial government, as I 
cannot doubt it will be ere long, what would South Australia, for instance, lose by giring up the Northern Territory to Crown administration? It will be equally open to all her colonists as before, with the probability of its rising to a far greater commercial height than if governed from Adelaide. Going still farther, if our Empire is to be united under one Executive, in which the Colnnial element is proportionately present, what substantial or practical difference is there in a Crown Colony as compared with any other of the Empire, save indeed to the Crown Colony's decided advantage in that all-important matter of the coloured labour?

So much, then, for this "Northern Territory" of the rast area of the Colony of South Australia, with its present total of 904,000 square miles, an area equal to one-fourth of that of Europe. But there is considerably more of tropical Australia than this to deal with. Happily, the Test Australian section, on the one hand, is still in imperial hands, most properly as yet unconceded to the handful of colonists at its far south-western extremity.* The Queensland section, however, rast as it also is, and specially important in its contiguity to New Guinea, is in a different position, and is perhaps a case less easy of management.

In discussing this question not long since with my friend Sir Thomas McIlwraith, who is now,

* Since this was written, I observe that Lord Knutsford has offered to the West Anstralian Colony up to sonth latiturle 26:, reserring the more tropical section twwards the egrator. This question is again discussed further on. 
lut was not then, the Queensland Premier, I was at once enabled to get at all the difficulties, as well as the other aspects, of the case. Sir Thomas, who, I beliere, had some personal interests-sugarplantation or pastoral squattage - extending into the tropical area, did not seem arerse, personally any more than generally, to the Crown Colony prospect. Indeed I could readily surmise that, looking to the reasonable probability of an early separation, as to local gorernment, of North from South Queensland, owing to the marked difference of interests and prospects, the South, where race and climatics will always continue it the predominant section, would decidedly prefer to deal with a Crown Colony, rather than one constitutionally free, on its northern skirts.

But Sir Thomas apprehended a different view of the matter from the urban and mining centres which were being rapidly dereloped orer the north. And there is no doubt of the difficulty, if their rote were to go "solid" upon the question. But that is just what I am unable to believe. (On the other hand, the squatters, planters, agriculturists of whaterer sorts, may be expected, to a man, to go for "the Crown," so as to attain the twofold benefit of securing the full supply of coloured labour, and escaping the possibly ragarious political dominancy of these town and mining masses. These masses, however, inherit, every individual of them, all the infirmities of our cool-blooded race, when brought under the hlazing tropical sum. They are all now, besides, whether under Colonial or Imperial Acts of Parlia- 
ment, the recipients of a good, and in some cases, as that of New Zealand, of a high-class education. Such men, in the tropies, where they are comparatively few, and are the best adapted to rule, should be employers and not employecs. I could never see, even in Brisbane, which, although hot enough at times, is not within the tropics, any of my countrymen doing exposed and menial work, which is Kanaka was much better fitted for, without the wish to give them a montli's imprisonment for needlessly affronting, as well as injuring, their blond and race.

\section{A Kanaka or Coloured Servant in Australia.}

One of my relatives, residing in the suburbs of the Queensland capital, had a Kanaka man for the miscellaneous outdoor work, and a better, alike for work and climate, it was hardly possible to imagine. Tommy, as he was called, was rather on the younger slope of middle age, active and rigorous, ever greeting the bright sun as an old accustomed friend, and with a contented or smiling broad face, of a nonrepellent light yellow-brown hue, finding nothing but enjoyment in his daily routine from early morn to dewy ere. He was tidy and clcanly in dress and habits, and his little bedroom, outside, under the raised verandah floor, was quite a picture for neatness. He had ten shillings a week of wages, besides his board and lodging, and he had a sacred regard for the money, which he trustfully invested under the friendly direction of his master. 
Tommy belonged to the New Hebrides group, having foumd his way to where he now was somehow or other not very clearly explained. He did intend returning some day, he said, with all his money, but was in no immediate luurry. He always attended church on Sunday, the Anglican I think, but what he brought back thence was not clear. I fear that Tommy had not been converted, in spite of missionaries and missions thick about him, both at home and abroad. His views of things were much too broad and too easy for that. He had a way of enunciating sage general reflections; not, however, without a suspicion of their parrot character as mere repetitions of "wise saws and modern instances" always in the colonial air about hin. Has not The Times suggested the like explanation in attacking much higher game than Tommy, when opposing certain of our Indian fellow subjects, who tried to enter Parliament under a flood of the most orthodox political and constitutional talk? Possibly Tommy, after all, approached, in at least some partial way, Gibbon's Roman magistrate, and had found that all the kaleidoscopic cirilisation he had been pitchforked into might be equally true or equally false, but to him and his co-Kanakas at least it was all equally useful.

But Tommy's excellences, in theix way, were diversified by certain sad infirmities of his race. For who, indeed, could reasonably expect that those who were used, with merciless indifference, to hack and hew, and perhaps, as the finale, eat up one another, should slow much consideration for the 
sufferings of mortal beings still lower in the scale. Tommy, who was equally ready to "thraw" a couple of ducks' necks, chastive the dog, or stroke his fitst friend the eat, was ordered one morning to make away with a litter of kittens of this same cat; for, although a cat is essential to complete the domestic picture, the vigorous reproduction in that direction has already made cats rather a nuisance in Quecrisland. Tommy was told to save suffering by dispatching the poor things at once. But we were horrified, shortly after, to see him deliberately placing them all in a shallow hole in the garden, with a covering of about an inch of soil, which he flattened down with the spade as though gently and lovingly bedding so many hyacinth or tulip roots. We vigorously called to lim to end at once this inch by inch torture, and forthwith he began chopping the kittens with the spacle, causing a score of little leg's to be thrown up in agonised gesticulation, Once more we strongly reproached Tommy, ordering him to inflict immediate death, an order he obeyed with undiminished serenity, after what he probably considered to have been an unusually pleasant and varied morning's work.

The Coolies, Malays, and especially these cosmopolitan philosophers of Kanakas, might, to some limited extent, transgress tropical boundaries and thus pass into Brisbane and elsewhere, but not I think to a degree socially injurious, or indeed otherwise than advantageous, for they relieve the domestic servant of our own lilood-the nolility of her class -of' a kind of labour and exposmre that might at 
once injure and discontent her. There is not, therefore, cause of alarm from any quantity of dark labour importation into tropical Australia. But the Chinese are a danger not to be overlouked. In moderate number, even in the semi-tropics, they are exemplary and useful in many respects, and those who have been allowed to enter should be protected, no matter at what cost, from the illegal and cowardly attacks made upon them by some of our colonists. But, as to the future, the Chinese authorities should distinctly understand that, as I have already said, we have in Australia the same objection to their swarming countrymen that they themselves would have to a relatively proportionate influx of ours.

\section{Interviewing.}

With Adelaide terminated a feature of my tour, which had been alike constant and vivacious, whether going northwards to Brisbane, or southwards through New Zealand. This was the interviewing on behalf of the successive local press. Some of the reports that followed were given with creditable accuracy; others were, in parts at least, most ludicrously wrong; while these latter were usually the parts I was most concerned, and had taken most pains to make right. But this I fear was chiefly from my own fault. Only upon general suljects which a reporter, in common with erery one else, can understand, is it safe to pour out in voluminous irregularity, trusting to your listener's 
powers of abbreviation. In less known or technical subjects, the same license or the same negligence is reasonably sure of some miscarriage of the meaning. I improved by discipline as I went along. Only on general subjects and questions did I take a conversational freedom. On technical subjects, such as market laws about loan issues, I delivered myself slowly and carefully, so that every word should be taken down, neither more nor less.

The most comic results occurred prematurely, I fear, in my disciplinary course, at Brisbane, at which town I was as usual promptly interviewed. One of my favourite expositions was upon the consolidation of stocks, so that a Colony should have its borrowingss in one perfectly uniform stock, instead of a number more or less differing. The main reason for this was, that the larger quantity of the one stock, by bringing it oftener into the market, made it more conveniently negotiable than if subdivided into a number of different small stocks. This convenience gave to mere quantity a distinct item of value orer and above what might be due to quality. For example, if Queensland had one uniform $£ 15,000,000$ stock, its price would stand appreciably highier, say by 1 to 2 per cent., if not more, than if there were fifteen different stocks of $£ 1,000,000$ each. Every one in the London Exchange was familiar with the fact that the old "Consols" stood higher, relatively, than any other British stock from sheer" convenience of the readicr marketability due to quantity. And even already the New 23 Consols, or "Goschens," are always higher, relatively, than, for 
instance, the "Local Loans" Threes, although both are, of course, identical in point of security.

IIy reporter, wearied perhaps at my long hammering out of unfamiliar distinctions, had summarised me into saying that the value of a stock in the market was due to its quantity. Some idea of that convenient kind must have been in the mind of the Turkish Sultan with regard to one of his loans in the London market about thirty years ago, whether the "Nutton Turks" or some other equally good, for, when he heard that fifteen millions had been tendered for the five offered, he was understood to have graciously agreed to take the whole.

But my story's climax is still to come. Along with this report next morning" was a grave "leader" of the editor, to the effect that, although these London financiers perhaps knew many things that were denied to more ordinary mortals, yet they were apt to be mistaken in such simple things as every one else knew but themselves; and one of these was that British Consols, and such leading securities, do not acquire their high value by their quantity, but only by their quality. 


\section{$(2 ! \%)$}

\section{SECTION XXXII.}

THE S.S. "ORIZABA" : ADELAIDE TO KING GEORGE'S SOUND, WEST AUS'TRALIA.

Or the 15th October we had to quit with regret the fair and pleasant city of Adelaide. At the railway station for the harbour, Chief Justice Way, to whom we had introductions, did us the honour to see us off, as we had been unable to meet before. But I had gone over his house and surroundings, one of the sights of the town in that way, the day before. Mr. Boothby, secretary of the Chamber of Commerce, and next neighbour to our host, accompanied us on board, and brought the useful present of a bag of magnificent lemons, all of his own growing:

\section{Superiorities of our Vessel.}

Now we run through the "Orizaba," in order to see what lind of home we are to be immured in for the next five to six weeks. We are first struck by the grand sweep of continuous deck, not much short of a hundred yards of a straight promenade. In fact, eleven walks to and fro make about a mile. I have never had such a vast marine field as this to live upon. My berth was equally to my satisfaction. I had applied early, and, as there was not the ex- 
pectation of a full ship, my old friends Messrs. Gibbs, Bright, \& Co., the Melbourne agents, had secured me the best of the cabins, and all to myself, a convenience I duly appreciate while writing my present work. The "Orizaba's" superiorities opened upon us more and more as the voyage proceeded. The very climax of convenience seemed everywhere reached in the accommodations. Even in the small matter of hooks, bolts and suchlike, which in other vessels would be at times put too high or too low, or in unreachable nooks or corners, were all here just where they exactly suited. My wife, however, found that the water-bottle of the berth washstand might be thought a trifle too high up, at least for the less tall humanities; but, as it must be either that or a diminution of the lieight of the intermediate lookingglass, those concerned in the matter had, doubtless, deemed the latter the more important.

Captain Conlan was at once a pleasant man and a good and strict seaman. He was surprised that I should forthwith detect him to be Irish. But the Irish tone is the most easily detected of all by those of "the adjacent island of Great Britain." Besides the Irish, I easily pick out the Edinburgh, the Glasgow, the Aberdeen tone. There is a broad guttural Scotch in Forfar and Fife, and the south of Scotland in general, not easily inter-distinguishable. But the Northumberland tone about Newcastle is again very clear; Yorkshire and Lancashire too perhaps; but beyond these, on the sonthward march, I have not as yet taken my bearings.

I had deened the "(Orizaha" to be the clinax of 
steamboat attainmont, with her sufficiently ample dimensions of over 6000 tons, her beautiful and roomy cabins, her fair speed of 13 to 14 knots, and so forth. Captain Conlan, however, put us in the way of expecting still ligher attainments. He thought, for instance, that berths should be furnished with chests of drawers, so as to get rid of passenger's' unsavoury leather and other portmanteaux and bag's. Even a greater improvement he proposed to attain by a system of periodical washing on board, which a few Chinamen, as part of the crew, could easily accomplish. One consequence of this would be that the heaps of old "duls" that are gathered together "good enough for the long royage" would be left at home, and passengers, who need bring only an ordinary array of luggage, would dress themselves more decently, and be much less of a trouble and obstacle both to themselves and their neighbours.

The scale of washing in a ship like the "Orizalua " miay be imagined from the fact that after her preceding royage, she turned out (not, of course, including any passengers' things) between twenty-nine and thirty thousand pieces for the tub, some of them table-cloths eight or nine yards in length. The ship's Company have a washing establishment of their own at Liverpool, where all the washing of the fleet is done. I should furtlier explain that the "Orizaloa" belongs to the Pacific Steam Narigation Company, whereas we now sail under the Orient line, the explanation being that the latter invited the co-operation of the other, by means of a loan of some of its ressels on fair terms, in order to supply the increas- 
ing demands of the Australian line, and thus keep down a competition by which those in esse might be disturbed by those in posse.

West Australia. The Railway from Albany to Perth.

We sped swiftly and pleasantly across the Great Australian Bight. It is, or should be, a voyage of three and a half days to a vessel of the "Orizaba's" quality, and we should have been there well within that time, indeed all but 'within the three days, had not "orders" arrived at Adelaide to await certain mail deliveries at Albany, West Australia, not expected till half a day later, so we lost in all about fourteen hours. Most unfortunately too, as we did not enter the Inner Harbour of King George's Sound, a most noble inlet equal to the accommodation of the greatest of fleets, we were to be denied the pleasure of landing, and I in particular of marking the progress of Albany since my last visit in 1857.

The chief item of that progress is the railway from Perth on the western coast, nearly north by west from Albany, and 268 miles in length. This is expected to be finished by the end of this year, 1888. It has not been made by the Government, as nsual in Australian railways, but by a Company, which is paid by land grant at the rate of 12,000 acres per mile of rail, and in alternate blocks along the line, so as to keep for the Colony an equal participation in the expected value the railway wonld confer upon the ground it traversed. The 
line, when finished, is to lie handed over to the Colonial Govermment, and by no means unwillingly on the builders' part, as the idea of such a line even paying its expenses for the present, in a place of such a handful of people, is out of the question. Even a daily train is perhaps a luxury yet very far ahead. But, again, all things may happen any day to auriferous and argentiferous Australia. Besides, the South Western or Cape Leeuwin corner of that rast expanse has a peculiarly fine climate, more genial and less in extremes than any other part. There is also into the bargain a good proportion of available land, which, amongst other natural products, has great forests of the Jarra tree, a wool of peculiar closeness of grain and fineness of polish, which cannot fail of finding application for many uses, and the trade in which has been already taken up by three considerable companies. In short, the harvest is great thereabout, but as yet the labourer's are few. 


\title{
SECTION XXXIII.
}

\author{
THE VOYAGE HOME.
}

\section{West Australia to Colombo.}

THe voyage home, like the voyage out, is part of my case. The progress in speed, in accommodations, in the general amenities of sea travel, are before me here also. Besides, we traverse, for great part of the way to India what are properly Australian seas. Bright and beantiful seas these so often are in this part, and especially at this season of the close of spring or dawn of summer! As the deep azure waves danced around us, under a stiff cool southerly breeze, which, however, did not very much disturb the quick steady pace of our great ship, we had enough of ocean viracity to recall and to justify our noble poet, who saw, reflected from the everlasting unrest of surface, the grand image of eternity:

Save to thy wild mave's play.

"Unchangeable,

Time writes no wrinkle on thy azure brow :

Such as Creation's dawn beheld, thou rollest now."

We were all delighted to learn, and that too, in most agreealble disappointment, after most of us laad taken our passages in Australia, that the company larl decided on the "Orizala" calling at Colombo. This was a new departure, as lietween the rival lines, for folomino had been strictly a P. \& (O. nest, 
which, howerer, it had now become necessary for the rival line to invade. These great rival caterers for the pullic good do try, I doubt not, to aroid one another's toes; but a crunching tramp will come sometimes. As for us passengers, as our captain remarked, there was a happy break to a protracted monotony of course from Albany to Aden; besides that there was so preciously little of a variety when arrived there; for I suppose that Aden bids hard for the palm of being at once intolerably hot and intolerably destitute of any other local feature or quality, good, bad, or indiffereut. Elsewhere we steer clear of our rivals the P. \& O., for while they go to Malta, we turn north, past classic Syracuse, Etna, and the Messina Strait, to lovely Naples. So altogether, as we scudded over the Western Australian main, and only too rapilly, as some might have regretfully thought, we had a very varied and pleasant prospect before us.

\section{The Australian Seas.}

Well out, as we were, to sea, in our north-westerly course in the Ceylon direction, we had the most charming of climates, with the usual clear and sunuy weather of this most faroured of ocean areas. A more in-shore course, over the fifteen degrees of latitude north from Cape Leeunin, would have proved decidedly, perhaps unpleasantly, hotter, for already over that great land area to the north of the temperate Swan River region the fierce heat of the northern sun was descending. But most of that 
region, and the wide domain still further to the north and cast, has been lately awakened from silent solitude and desolation to the well-known sounds of gold digging; while, if my threefold division of Australian soils, which assigns the most sterile to the precious metals, have any confirmation up thereabout, an unprecedented harrest may be in waiting: for that heretofore but little known or little appreciated part of the empire.

While we traversed 1200 miles of Australian seas, and experienced the pleasant climate we mored in, my imagination fell to work upon the future. These are indeed claimable as Australian waters, because, although the distance of the Australian shore increased, with our north-westerly course, up to a thousand miles, there was no other nearer main shore to dispute the proprietorship. India, Ceylon, Sumatra, Java, were all over and away into the torrid zones of a lower destiny and civilisation. I realised the future, when progress in shipping and in all else will immeasurably further utilise this delicions occan area. With a steady southerly or south-westerly breeze upon our quarter, the shade temperature hardly exceeded $70^{\circ}$ as the day maximum, and was only $72^{\circ}$ when we had passed by several degrees within the southern tropic. After that, indeed, when we must needs resign the seas to the Indies, the change of wind to the north-east trades sent our thermometer to $80^{\circ}$, and to the realisation of a final adien in that direction to Australia. 


\section{Ceylon and Native Labour.}

Night orertook us as we made the Point de Galle light, is miles from Colombo, and I went to sleep, regretting that green spice-smelling Ceylon was to be passed in the night. But rery early next morning. hours before daylight, I was awoke by a terrible clatter of human roices, and of a rariety of other noises. I knew perfectly what it was all about. for I had been twice before at Galle, where I had experienced the coaling of the steamer, and I now recognised the old scene, and its noisy accompaniment. I looked down from my cabin scuttle upon a hundred Coolies. yelling and working together amongst countless bagss of coal, which they hoisted to successire stages, and finally into the "Orizaba," in a wonderfully rapid and orderly way. Each bag might have almost a hundredweight, and to each were four Coolies at the respective stages, who lifted it comerways, till emptied into the great coal bunk. These men, perfectly naked beyond a mere rag at the middle, their oiled and perspiring bodies shining in the sun, after the sun had risen, seemed to be absolutely untirable. They seemed, too, to enjoy their work, if one might so interpret their satisfied faces. No disposition to strike here, even although but $9 \pi$. a day was all their pay, as compared with the 10s. 6el. to $13 s$. which was just then being so angrily rejected in Australia. 
The ITumblest may, in his Turn, be King of the Situation.

I was reminded once more here, as I have been in other ways and places luefore, of the supreme ralue of the man, as distinguished from his wrapjings, horrever pretentious or the reverse. Men all so much need one another, that every class seems, in turn, upon opportunity, and for the time being, to come in as king of the situation. Now it is, may-be, a great king, another time a poor naked Coolie, and at other times other classes, in great, in small, or in indifferent positions, as men view these cases.

Let us take some instances. A friend of mine, on one occasion, was detained so unexpectedly long that it seemed hopeless to reach his train in the nine minutes of time that remained; and yet, if he missed that train, what to him was of the greatest consequence was seriously jeopardised. All but in despair, he called a hansom. Holding up his watch, "Euston, nine minutes, possible?" he gasped inquiringly out; "remember that special service requires a special fare." Cabby, who was very leisurely smoking his pipe, remored the pipe quietly but quickly, and had his coat and knee-wraps all in order as soon as his "fare" was seated. "It's to be done," he said, in a quiet but clear roice, and the next instant his race for the throne began. "God's merey, how near a violent collision with that carriage-wheel!" Yes, but it is cleared, and with a good quarter inch to spare. And, again, can this 
block ahead be possibly turned? My friend harl hardly seen it ere it was flanked. The wheel hard got somehow twelve inches upon the footway, and one old lady's toes made a marvellous eseape. The policeman, officially angry, but really in admiration, let the culprit go, because, as he seemed to plead in excuse, at his pace it was impossible to do otherwise. When cabby suddenly stopped, his fare was almost sent forward into the railway porter's arms, but there was just time before to catch a quiet voice from the little porthole above, "All right." My friend put the sovereign he had ready in cabby's hand, almost. feeling that he should have made it five. But the satisfied face of the recipient settled that point. "Sir," said the latter, with an emphasis that contrasted with his previous quietness, "Sir, you are a gentleman." And my friend passed on, impressed that he had received both the crowning serrice and crowning compliment of his life.

In this case cabby was king. In another, more directly to my purpose, and of which I was myself the witness, Jack Tar passed, for his time and opportunity, to the crown. When, as I have told, in the tight little S.S. "Penguin," of the nowadays despised size of 900 tons, we proceeded from Manakau Harbour southwards to Wellington, we were caught in crossing Cook's Strait, from New Plymouth to Nelson, by one of those terrific squalls not uncommon to that restless marine quarter. Never in my life did I see or feel such wind. Our sails were out, and they seemed to me doomed, unless indeed they could be hauled in by rope machinery in place 
of human hands. Mortal man, thought I, could never ascend those masts and come down again in safety. The sails flapped so furiously that they presently went into ribbons, and pieces of a foot square or so were chucked out of the sail as if had been soft cardboard.

But to my astonishment, and almost horror, and almost ere I could tell where they came from, four men had got aloft, and were fighting with the furious chief sail. Having mastered it somewhat with the tie cords (whatever their right name is), one of the men, I suppose the weightiest, jumped right out upon the still bulging and flapping sail, as though upon some furious wild beast, and I looked for his being momentarily jerked off by its contortions. But he had calculated better than I had, and, sliding down while the fastening from above by the other hands followed him, the job was already done. "Captain," said I, "those are good men." The captain, who impressed me as being a fine scaman, and whose eyes and mind had before been riveted upon his struggling hands, had now leisure for other things. "Yes," he replied, " and if they weren't they would not be here."

Next morning, as we approached Nelson, peacefully asleep as it lay within its grand panorama of snow-topped mountains, at the head of the Tasman Bay, now quiet as a mill-pond, I asked the captain if I might speak to those four men. "Oh, never mind that yesterday aftair," he said; "they are all busy now ; they'll have forgotten all about it by this time." "But I would like to see them," I still 
pleaded. "Well, here happens to be one of them. Tom, this way; give an account of yourself." Tom came modestly forward with an inquiring face as to why he was wanted. When I spoke of the terrible squall the day before, "Yes," said he, with an emphatic accompaniment, "and it cost me my cap." I dropped a sovereign into his hand, to restore the cap, and give all four a bonus besides. So all that had remained in 'Tom's mind from this heroic incident was the loss of the cap. One of the luxuries of these lingship cases is the fact that the actors themselves are often so utterly unconscious of their grand rank.

There was another variety in this way which I may also mention. While looking down with intense interest on the hard-working kings below me, on whose sweating but indefatigable bodies the ship's voyage and all her passengers' interests now depended, I noticed alongside of me a lad of about fifteen, whose rather slim but still handsome figure and pleasant young face at once attracted me. I considered how I had best accost him, for that requires care, as otherwise he drops at once into the importunate beggar, and then all poetry, like love, flies out of the window. He was evidently no capitalist, judging from the little bit of coarse dirty shirt, his sole clothing, from his loins halfway to his knees, unless indeed my late friend Professor Bonamy Price's view be sustainable, in taking the man bodily as capital. I pinched his shoulder to realise the velvety softness of the light-brown skin. As I expected, he got all alive the moment he realiser that he was in 
my mind. Previously, when not aware that I was even looking at him, he seemed the most care-free, unconcerned of human beings, seemingly without the trace of an idea that he was an object of interest or poetry or other such incomprehensible nonsense to anybody.

I took him for a young Tamil, not yet ready for the hard work around him by two or three years. I found that the young fellow spoke English, so I asked if he was at school. "No school," he said. He lived with his father, who worked in Colombo. Then $I$ asked his age, but he began to assume that look which says, as distinctly as words, "that sort of useless gibberish be hanged; what are you going to give me?" He pointed to his stomach, as though rather empty, and to his poor rag of greasy clothing, and asked for a penny. There was a touching plaintiveness in his voice, but whether of nature or artful imitation, who could tell? I noticed that he was chewing something, indeed he was so constantly spirting out the dirty juice that I wondered where so much saliva could come from out of so young a frame, and how he could keep in the health he seemed to enjoy under such waste of Nature's proper sap. He said it was tobacco, but when, after one last strong suck, he spat it all out, I saw, in the dry "bones," the most wretched of quality. I shook my head, and said "Don't smoke ; very nasty." But he took no heerd of this. With my handkerchief I then wiped away the dirt from the lips, which were soon so natural and inviting, with bright white teeth behind them, better by infinity than my own, that I 
would have enjoyed a kiss of them, albeit they had just a little of the negro fulness and pouting. But I thought better of it under all the circumstances. Then I gave him a silver threepenny. There was in response a gleam of pleased surprise, almost rising to gratitule. But the next moment the expression reminded me of the proverb that gratitude consists of a lively sense of still more farours to come. I thought, therefore, that I had best make off, in case the last shreds of the poetry of the case might disappear.

The "Orizaba" burns a hundred tons of coal per" day, so that an awful number of bags had to be lifted and emptied in order to supply us for at least ten or eleven days' royage to Port Said. And all this was done in wouderfully few hours, so that we were off once more, primed to the full by 4.30 P.x., including some spare hours of time besides, to sweep up the coal-dust. These hardy workers are not the Cingalese, who are a delicate, effeminate lonking race, wearing their long black hair jut ul, with romul combs, in a way to confuse them, to our mincls, with women. These Cingalese, then, are mostly employed in shops and in the lighter work of trade. The Hohammedans again are a distinct cliss, an well as race, in general markedly superior, and distinguished by ligh skull-caps of varied basket-work; while the Parsees, or Fire-worshipper's, a race ustally marked by corpulency, and with the peculiar dark basket head-dress, leaning back off the forehead, completed the variety which swarmed around, ceaselessly trafficking in money and wares. They got a good 
harvest at first by pretending that the rupee exchange was fourteen to $£ l$, when it was within a small fraction of fifteen. The hard workers are chiefly of the Tamil race, belonging to Southern India, and coming mostly from the west coast about Calicut. Very moderate pay, about ninepence a day, suffices them.

\section{Ceylon Features: Traficking; Schools.}

Our vessel was soon one great market, in fruits of many kinds, and all sorts of native fabrics, in silver and gold, tortoise-shell, ivory and porcupine, ebony and cocoa-nut wood. After early breakfast, we sallied forth with friends, who were residents, for sight-seeing. We drove out about a mile and a half to our friend's "compound," through native streets, crowded with people of either sex and every age. All the young people were all but naked, and the older people, the working males at least, not very much better. But the dark skin has always the effect of elothing, else how could our modest young damsels complacently regard the fantastic movements around them, especially the diving after silver money. The scene of so much busy life was pleasant and inspiring. All the different races and faiths lived in real or apparent amity, under one and the same government, which gave them all equal rights and laws.

Opposite our friend's compound was a Catholic church, into which I sauntered with. my friend's sister-in-law. We found about one hundred little 
boys at school, all darkies, more or less, with lright eyes and cheery, smiling or laughing faces; and when we went back to the far interior of the building we found as many girls. These are almost without exception Cingalese children. They are brought up in the Catholic faith, and taught realing in their own characters and language. It is generally difficult to get regular attendance at school, as the parents miss the children's help at home, and attach but little value to the lessons.

The Catholics, as they tell us at least, have been successful here far beyond Protestants, whose feel,le rival power, although backed by so much money-spending, as the local pricst here significantly remarked, their rivals rather despise. This church building was originally Italian, as the inscription over the doorway showed, but is now under French charge. A bout one-fourth of Colombo, with 109,000 people, is Catholic. This priest told us that in all Ceylon there were about a quarter of a million Catholics to 50,000 Protestants. He was an affable, pleasant young Frenchman, apparently interested and happy in his religious duties, for what else could lieep him in this tropical clinate, with a monotonous and inferior society of this kind? We discussed French affairs-" la belle France, toujours la belle," but with so varied and uncertain a government, Geueral Boulanger being the last hand that was once more stirring up the Chapter of Accidents. 


\section{Colombo Harbour.}

Colombo has been made a great and convenient harbour, by a half-mile of a low but substantial breakwater over which the fury of the westerly winds spends itself in a ceaseless spray and overwash. There is much commerce with the larger class of steamers of through-line passages. A large P. \& O. boat had arrived the day before us, and a "Clan Line" boat the same morning, while the "Thisbe," a German steamer, left early that morning, further eastward bound. The mail steamers, going and returning, with their many purchasers greedy upon bargains, keep the shops and dealers all alive. We had not time for many of the sights, but one worth seeing came in our way, namely a renerable tortoise, known, it was said, to be at least 200 years old. Te saw him with his long projected neck eating grass like a great unshapely goose. He is one of the "adscripti glebe" of a private property, and always goes with the occupant, whether owner or merely renter. Having read up the telegraphic summaries since we left Albany, ten days before, we started once more, having in prospect another ten day's' reading up at Port Said, our captain already liuting a disapjointment, namely, that we may not require to call at Aden. 


\section{$(313)$}

\section{SECTION XXXIV.}

THE VOYAGE HOME: COLOMBO TO ADEN.

Tне Captain declined to say positively if we were to be indulged or not with the call at Aden until the day before our arrival there. It depended on the coal question. But a day or two before the decision a whisper was started amongst the ones knowing in the coal case that we would call, and accordingly some of us got their shillings and rupees in readiness for further trafficking.

But we had, on the whole, a fairly pleasant voyage prior to reaching Aden, for, after all, at the appointed time, the decision was to go in there. We were to see no land from leaving Colombo till we were off Socotra, four days' distance. We would sail close to that new acquisition to our Empire, and were to diverge slightly from the straight course so as to pass it ou the north side. Our greatest heat hitherto had been for three days after westing from Cape Comorin, when the thermometer touched $83 \frac{1}{2}^{\circ}$ in the morning and 85 after noon. Towards Socotra, with a south wind from the open ocean, it was rather cooler, with the glass ranging from $78 \frac{1}{2}^{\circ}$ to $81^{\circ}$.

This intensely tropical Socotra is a large island, virtually within our empire, because, a dozen years ago, we agreed with a kind of sultan there, who had 5000 subjects engaged in pastoral pursuits and aloegrowing, producing, it is said, the best aloes in the 
world, that, for a "consideration" on our part, he should not permit foreign settlement without our consent. The island rises in marked outline from the ocean, is 80 miles long by 23 wide, and consists mainly of an elevated plateau 800 feet abore the sea, with mountain heights exceeding 4600 feet. Rapidly, while we neared the island, the deep azure of the water changed to almost a light green, indicating the reduced depth, as we had noticed on the outward royage, on nearing the Cape de Terdes in West Africa. But past Socotra it became darker, and towards Aden almost the deep azure once more. Supposing, which we must do, that this change is a question of depth of water, are we not to explain the Aden depth, by the everlasting current or scour caused by the influx into the Red Sea, to restore the diminution there by evaporation? Curious to say, not one river runs into this vast inland gulf, so that the yearly evaporation would soon tell upon its level, if the Perim strait did not let in the outer ocean. The yearly evaporation is estimated at so much as $24 \frac{1}{2}$ feet.

\section{Coaling at Aden.}

We were to enter Aden at three in the morning. The genial air of the night brought several of us on deck to usher in the fiery Arabia. We were unexpectedly pleased with the temperateness of the weather. With the earliest streaks of light, if not indeed sooner, came a Babel of roices-men and boys in everlasting chatter. Two great hulks, full of bags of coal, had already lieen drawn alongside. 
The stewards were already busy lifting the carpets to save them from coal dust, and all ports on either side had been screwed tight. From the deck we saw a spectacle somewhat similar to that of Colombo, differing chiefly in the race and aspect of the workers. There we had Tamils; here we had Arabs; the latter the finer and stronger men. They worked under their sheikh, and to him was the united earning paid. The two races seemed to me to work equally well, never shirking the toil, but on the contrary taking it joyously, as if the pleasantest thing in the world. Money is wonderfully efficacions in making man enjoy his exertion and his labour powers.

Around the steamer were a score or more of boys with their little canoes, all offering to dive for silver money, if thrown over to them. There is foolish waste often in this way. One passenger opened the ball by throwing down a florin, which a boy picked up and put in his mouth before it had sunk twelve inclues. This only demoralises them. The money does not sink fast, and is easily seen by the little fellows' sharp eyes under water. A threepenny silver piece at a time is best, as all then have fair chance of a share. These nimble little fellows seem to have no fear of sharks, which, no doubt, are as plentiful here as elsewhere in such latitudes. Indeed I was told that a shark or two are at times playing amongst them, with great mutual forbearance. But one man did pretend that sharkie crunched little fellow at times. I suspect not, however. The little fellows are much too cool and 
quick, and could, with their eyes always open, easily be warned in time and get out of the way of the shark's cumbrous motions.

\section{Bargaining.}

Almost as early as the diving boys, came those with the local wares, of which there is now, with the large and settled population, and regular and frequent calling of large steamers full of rich passengers, no small variety. The wares are also really good, and remarkably cheap if you know how to deal with these practised hands. Ostrich eggrs and feathers, party-coloured basket ware, and prettily patterned grass cloths, were amongst the real natire wares, along with a dubious lot of finer fabrics, sticks, blackwood elephants, porcupine boxes, \&c., most of which I suspected were only importations from Ceylon. Other indigenous products were pairs of Oryx or Gemsbok horns, beautiful flowers of white coral, and rarely fine shells, particularly spinous murexes, which went in basketfuls for a shilling. English money had now got to be preferred to the rupee for its steadiness. The poor rupee had been travelling down continuously from $2 s$. in the old bimetallic times fifteen years ago, to $1 \varepsilon .4 d$. in these excess silver-producing days. The rupee was indeed accepted, but with a disposition to affront it eren to beyond the depreciation of the last Calcutta or Bombay exchange rate. When, for want of more English change, I tendered rupees, they were refused except at a shilling each. 
Unfortunately there was no time to land, as we were to leave before breakfast. As the time approached, there was visible commotion amongst the traders to complete their sales. Like the common Whitechapel or Houndsditch ticket, "no reasonable offer refused," so there was an eager waiting for any offer. Prettily patterned and strong well-woven water-bottle-shaped baskets, of the larger size, which had opened at $2 s$. each and had long struggled at $9 \pi$. ., fell at the last to $6 \mathrm{~d}$., which seemed indeed incredibly chieap. "The line must be drawn somewhere " even in baskets, and this $6 \mathrm{~d}$. must have been just outside of the line, for I heard of but one sale, all the rest of the baskets having been indignantly hurled back into the trade boats at final departure.

Our purser must have been alive to all the local dodges, as he easily managed his opportunities. One boat came alongside with a good score of fine solid fresh-caught crimp blue mullet. He showed no indication of wanting them till the departure bell rang out. But ere this the impatient sellers had begun to fill two large tin cans, and, in real or pretended confidence, were just gliding the fish up the side ladder, when the purser sent an offer of $5 s$. for the lot. With all the sigus of violent indignation for such an affronting offer, the cans were hauled down again, and emptied into the boat, with the apparent intention of going off at once. But still Mr. Purser made no sign. Then, after a few seconds, the boat chief, in a much less hostile way, made an indication that the $5 s$. would be taken. In a few more seconds, with the two half-crowns in his hand, I noticed a 
chuckle of satisfaction as though to tell that, whatever more he might have preferred, what he had got was at any rate better for all the sellers than the fish.

Importance of Aden: its Various Races.

Aden has now a variety worth seeing, as it grows in importance every year. There are above 30,000 people here under British rule, who all seem very busy, and, so far as we could tell, very content, and fairly prosperous. What was to them a prodigious sum of money must have flowed out of our "Orizaba," possibly not much, if at all, under a hundred pounds in a brief two hours of early morn. There is a curious variety of races, amongst which one easily distinguishes the light-hued true Arab, with his congener, not much removed, the Arabian or Syrian Jew. Then we have the Hindoo, chiefly from Southern India, more swarthy than Edom, but often a fine, handsome fellow. From this we leap very distinctly to the African, the negroid man of the Galla tribes across the Aden Gulf, with his rather protruding lips, whitest ivory teeth, and curly jet black hair, unless turned to a dark ochre by use of lime. The difficulty to discriminate is with an evidently intermediate race, called the African Arals, who boast of being Arab and Mohammedan, but admit that "Afric's sun" has darkened their skins. But one would think that Aden's sun was not much short of Afric's in that matter. Any way, they are a fine race, the youths tall, well formed, although in hair, protruding lips, de., they sway 
nearer to Africa than Arabia. The Alyssinians, Nubians, Coptic or original Egyptians are all, I believe, similar puzzles, where a race originally mixed, of two or more elements, from very far back, has assumed later a permanency of type.

Several considerable steamers lay around us in the Aden anchorage, all English, as far as we conld judge, and there were a number of sailing ressels small and large, mostly dhows and other natives, further up the harbour, towards the fortifications and Aden proper, a considerable Arabic town. One steamer was the "Quetta," for some years past in the Queensland mail service. Another had lately arrived after rumning upon a previously unknown coral reef in the Red Sea, which had ripped open her bottom, so that she had a sinking look, with a section of her hold filled with water. This reef was rather an unpleasantly alarming discovery at this late time of day. Shortly after starting we overtook a cargo steamer which had left Melbourne, a week before us, with the early wools for the first or Norember London Sales, our own "Orizaba" also having, at the last moment, bargained to take, for a moderate freight, a good deal of wool for the same destination.

Aden's present importance only restores it to the consideration it repeatedly enjoyed in past times from a far antiquity. But the remarkable great water tanks, which, buried by time, we began to unearth about forty years ago, were not older than the twelfth century, when they were constructed under Mohammedan civilisation, further adranced as it was in some respects, than Europear at that time. 
Returning Home this way in 1853, I saw our people at work clearing out from these tanks the débris of gravel, \&c., which centuries had accumulated. Aden was of comparative importance also 2000 years ago. Much more could be done for it now by irrigation, as there is soil all about which would be at once largely productive with the lifegiving water. 


\section{( 821$)$}

\section{SECIION XXXV.}

THE VOYAGE HOME : ADEN TO POR'T SAID.

As we left Aden on the 6th of Norember, we were allowed to enjoy the idea that about the third day in the Red Sea, when we had passed through its southern half, we would lee wafted into temperate weather, with the north winds there prevalent towards the winter and spring seasonis. A south wind blew stifly from Africa as we went full speed, with our better quality of coal, towards Babelmandeb Strait, and was not umpleasantly hot with the thermometer about $83^{\circ}$. We took the broader channel on the west side of little Perim Island, where once more we looked upon our Empire's territory. It is three miles long, in north and sonth direction, by one mile wide, and, while the wider passage which we entered is twelve miles across, the narrower, on the east side of Perim, is only one mile and a half. We saw a small harbour and a fort, and several other buildings on the island.

\section{The Red Sea.}

Some of us, perhaps only a few, scomed to feel a sense of awe and interest in entering this famous old sea, which is indeed the most remarkaljle sea of the whole earth in its geographical physics. 
Although with a coast line of twice trrelve hundred miles in length, besides indents, not a single river, as I have previously remarked, runs into it. The consequence is, that with its great evaporation-24 to 25 feet of depth of surface a year - all the water would have been dried up geological ages ago, but for the constant indraught on either side of Perim. As the eraporated water is fresh and the re-supply salt, one would expect that in time this long and comparatively narrow sea would be filled with solid salt. There seem no indications of this as yet, although, doubtless, its waters are much salter than those outside, especially towards Suez at the head. The sea, however, is full of fish; we saw more flying fish, up past its middle parts, than any where else. The canal now pours into the upper end at Suez a small supply of water from the Mediterranean.

The Red Sea is extraordinarily deep for its area, as we might indeed have inferred from the deepocean azure hue of its waters. About the middle it is 1050 fathoms or 6300 feet, a depth which would swallow our Highland Ben Nevis bodily with 2000 feet to spare orerhead. Suez Gulf is comparatively shallow, but its sister inlet to the east, the Akaba Gulf, continues the deep cleft of the main sea, and is 200 fathoms close to the furthest end. The deep cleft recurs in the famous old "Dead Sea" of Palestine, which was no doubt the upper Akaba in a geological retrospect. As the Jordan does not nearly compensate the eraporation, there is not only no outlet of the sea, but a balance on the drying up account which settles itself at a reduction of surface 
level of more than 1300 feet helow the Meriterranean.

The only perfect calm of the royage necurred on the second day after entering the Red Sea. It lasted hardly twelve hours, and was an interesting variety, as we looked far and wide over the deep blue of the water, smooth and bright as a mirror, no land being anywhere in sight. We had, shortly before, emerged from a sort of scum on the surface, which I supposed might be a light pumice sort of sand, blown from the desert on either side, but which our captain explained as an off-throw from the subjacent canal. It hat an oleaginous appearance, and enitted at times an umpleasint smell, although that was not at present discernible.

As we expected, we met a strong cool north wind when half way up the sea, and thenceforwards our heat trials terminated. The thermometer, which, two or three days before, had tonched $s, j^{\circ}$ in the shade at the southern extremity, fell to sit at noon in this central part, and was at $72^{\circ}$ off Suez.

\section{The Suez Canal.}

Unfortunately it was night when we approached the Suez Gulf entrance, so that we did not see grand Mounts Horeb and Sinai; but we had compensation in many objects at and about Suez in the morning, and, later on, in the Canal, and the next morning at Port Said. I can imagine the Canal to be monotonous to those who go often through it, but to myself who saw it for the first time it was through- 
out most lively, varied, and interesting. In trwo previcus passages of the Isthmus, in 1853 and 1857 , I had seen just the dawn of modern progress, leaving behind it the old traditional Biblical conditions. The first time, we had only horse waggons from Suez to Cairo, and thence, by the Nile steamer and the Mahmoudie Canal boat, to Alexandria. The second time we had improved velicles to Cairo, and the rail beyond to the Mediterranean. Now M. de Lesseps has changed all this old story.

There was quite a busy and varied life along the two canal banks. There were now and then native villages or hamlets of a few mud and straw huts. These were varied by the comparatively good houses of canal stations. There were jetties and boats at intervals. Many native " navvies," in blue cottons, were working along the canal. On either side was a sort of public highway, along which many Arab men and women were travelling. We would also see an occasional Arab or two posting across the desert. Everywhere there were camels by the dozen helping at work, and everywhere as we passed young and old would roar out for backsheish.

\section{Port Said.}

Between three and four in the morning we were up at Port Said, as we knew ly our bed-steward entering to screw up our lights, so as to keep out the approaching coal dust. Presently the great coal barges were hauled alongside, heralded lyy the usual Babel of the voices of the workers, 
their directing chiefs or shiekhs, and the agents of their employers. After some little time to adjust the successive stages in passing up the coal bags, that being a matter of first importance, the coaling work began in right earnest, for no workers are equal to those coloured sons of the tropics and their vicinities. The fair "Orizaba" was presently in a shower of coal dust; and as we looked back upon her in our escape ashore, like so many Lots rushing out of Sodom, we saw the smoke, but happily not, this time, the smoke of her torment, ascending up towards heaven.

We had nearly two hours of early morn for a ramble through Port Said. The large passageressels are out in the stream. Countless smaller, including Arab dhows, \&c., are along many lines and cross lines of wharfs. It was Sunday morning, but this did not seem to make much difference, excepting that we passed some well-dressed people and European children coming out of French Catholic churches or other public institutions, which seemed numerous all about, distinguished by the plain cross. These were varied by mosques, \&c., distinguished by the crescent. A structure with a small Byzantine-looking dome, and a complex cross, we șet down for a Greek church, the Greek element here being large, as it was in Alexandria, preceding Port Said. As we probed our way through the rectaugularly laid-out town, we were surprised at its extent and population. There seemed nearly a :quare mile of streets, the principal thoroughfares being well packed with an endless diversity of 
humanity. There was also ceaseless trucking and trafficking, and only one beggar crossed our path, a man with both his feet doubled up, and who, as the sole nuisance in that way, and as a mere curiosity, had some right to backsheish.

All this vast work we had come through was due to the initiation of one man; and it was accomplished under such apathy on the one hand, and opposition on the other, as might, without him, have delayed the work for generations yet to come, although, of course, it must, in the cause of progress, have been ultimately done somehow. I have met M. de Lesseps twice. The first time was when he lectured at Edinburgh, in 1854, upon his grand project, and to an audience which, like myself, was, I fear, wholly unbelieving. The second time, a generation later, was after the canal had proved an enormous success, and when its author met the London Chamber of Commerce, of whose first council I had the honour to be a member, in order to arrive at agreement about transit charges. Even M. de Lesseps, it was alleged, had condescended to John Bull's halit of making a good dividend, to those who had supplied him with the money, the first consideration as to the canal. The Chamber, however, could respond that English commerce supplied nearly all the dividend. There was eventually, I think, a fairly amicalle agrcement.

This master spirit of the time, not satisfied with his one surprising triumph, has made a still greater plunge to bring up a second. We must all hope that he will live to witness the Panama enterprise, 
deliyed, as yet, ly mexpected, and indeed, noncalculable costs and difticulties, finally completerl, for completed this greater work also must needs be, like the lesser work of Suez, at some time in the world's interests; but if eighty-four years of age may endanger that further honour, the hero of the suez Canal must be content to have already attained to the forefront in the physical progress of the world. 


\section{SECTION XXXVI.}

THE VOYAGE HOME : PORT SAID TO NAPLES.

Biddrag adieu to the busy Babel of Port Said, we stood out into the Levant with a pleasant southwesterly breeze, warmed by adjacent Africa. Egypt is, perhaps, at its perfection in this month of Norember, with thermometer at $60^{\circ}$ to $70^{\circ}$, and with the mellow steadiness of autumn, as compared with the hot sun of the day, and the cold nights and cold winds of spring. The next day, with a change of wind to north-west, we had quite a storm, the first of this experience since we left Adelaide. Consequently we did not take well to it, and the dinner table, at least in its female muster, approached "decimation," the nine-tenths, however, being this time decimated instead of the one-tenth. Towards midnight, we were glad, like a more illustrious voyager of many centuries back, to find some shelter under the lee of Crete. The next morning, however, dawned beautiful and genial, and the morning after, just before daylight, the faithful stewards summoned us all to deck for the entrance of the picturesque and beautiful Italo-Sicilian strait.

There, for three successive and far too rapidly speeding lours, we passed a scene which, for the beanty of variety, conjoined with its crowding classical ansociations, extending lack to the very 
dawn of history, was perhaps the most interesting in the world. It was not till we were twenty niles beyond Messina that grand old Eina cleared up for our view, with one half of her 11,000 feet of height covered with snow. Stromboli had a dense white cap of cloud just upon its top. We presumed it was cloud, as we saw the heavier, darker smoke of the volcano struggling out from beneath. While we looked in the direction of Lipari, a great dense snoke arose from its northern extremity, indicating - a volcanic outbreals. We all fell to disctssing the exact canse, some asserting that the island han been quiet for centuries, others that it was regularly or fitfully active. In any case we recrarded a most interesting olject, and at such safe distance as mate us rather disposed to welcome a great spectacle; but after an hour or two the thick mass was eridently on the wane. After arrival at Naples, we learnt that there had been a fresh outlureak in that quarter, beginning some few days lefore, so that what we saw was not the first of the eruption.

\section{The End of our Pleasant Voyage.}

And now, as we steer at our thirteen to fonteren knots for Naples, where we are to arrire soon after. dark, our most pleasant royage ly the "Orizalan" draws to its end, for by telegrams at Port Said we find that we must hasten home, to see certain dear ones of our circle who are to proceed to that firr-off Melbourne, from which we have just retmenel. I long royage is generally credited as an ordeal which 
exposes accurately what people really are, whether good or bad. A young man may safely marry any attractive young maiden who, in temper and conduct, has well acquitted herself during an Australian rorage. This ordeal has thus its advantage in showing and attesting personal excellence better perhaps than any other. I am pleasantly reminded of this in the attachments we have already formed on shipboard. The value of women to society is there especially prominent. To have the privilege of the constant company of a number of pureminded, well-educated, and well-conducted women, not a ferr of them clever and well informed besides, is something that may alter one's whole aspect of life. I suppose we are to be considered fortunate in having every one of our lady cabin passengers more or less up to this high mark, as well as to have been free of even one ill-conducted male cabin passenger.

Nor were we at all an undistinguished company, in matters even beyond "mere" respectability, if I may dare so reckless a way of speaking of so high a quality. Besides our own family party, whom, by right of the law of opportunity, I will venture to speak of first, lut will not further discuss, we had the wife and daughter of the late distinguished political economist, Professor Cairnes, the senior charming for her general information, the junior not. less so in other and appropriate ways. Next we had Mr. and Mrs. May; she a bright young life and wife, most pleasant to lonk upon; he an artistic delineator of the first power, attached to the Sydney 
illustrated press - a power he exercised at times upon some of the more delineative of the passengers, to our and their own intense amusement. The comple divided just fifty-one years almost exactly between them, and there was a mutual devotion which enhanced all their other qualities.

Then we had a son of "Thomas Cook and Son," but not possibly the son, seeing he was so young. We mderstood he was the grandson of the original. He was trarelling. doulitless, to qualify himself to snecced his senior. He was a pleasint, intelligent young fellow, and could not be called a too pretentious youth, seeing that his distinguished senior had attained to the pesition of the prince of the world: modern husiness of travel. And. again, we had one of those strong practical spirits of young Colonial life. who help their respective colonies to run as by Mr. Gladstone's "leaps and boumds," to their fast developing destiny. This was Mr. John Wagner, whom I have elscwhere occasion to mention as a chief proprietor of the Mount Morgan Gold Mine, as well as a chief fluckmaster of Anstralia. Although alreaty even a millionaire in means, he had a good quiet common sense, as thongh he were only beginning, instead of ending, his fortune-making.

We had also our friend Mrs. Stewart, the late lady mayoress of great Melbourne, who, like the present mayoress, Mrs. Benjamin. of whom I have already spoken, was able to entertain and astonish us by accounts of the scale and style of the civic hospitalities. On the occasions of the balls got up during the vorage, she would, in honour of her 
company of course, array herself in a costly gift of diamonds, to our captain's visible anxiety, in view of the opportunities thus afforded to possible dishonest individuals of crew or passengers. At last, on such riskful occasions, he "detailed" a man to watch her cabin. As a robbery of $£ 1500$ in bills, bank-notes, and gold, had occurred on board during the last of these balls, our captain's precautions were not unneeded. Mrs. Stewart, however, could claim ligher merits than even those associated with her public gift of dianonds, for she was the mother of no less than twelve sons and daughters born to her great Colony.

Lastly, we had Mrs. Dickins, who, with her husband, was returning from a three years' starring upon the Australian stage. Although I have placed lier the last, that is not because she was the least in my category of qualities, but rather because, having the most to say of her, she makes my most effective ending. Mrs. Dickins rather surprised me by saying that she did not like the stage, for I remembered her successful appearances at the Savoy in the fairy way and otherwise, under her stage name of Miss Alice Barnet. She, however, had taken to it by compulsion of family necessities, which may somewhat account for the dislike of her vocation, in spite of her suecess. She amused us by some of her remarks. She did not like actresses, she said, and would never, if she could help it, ask any of them to her house, for the bad ones were not, of course, to be asked, and the good ones were not worth asking. Ilor tall and robust form toll us that it 
is only in fairyland that she could possibly dance upon a gossamer (whaterer that may be) with Iolanthe; or, with nimble toe, pass, with the same light comrade, along one of Mr. Astronomer Ellery"s attenuated three-ply spider thread. But we were not to wonder at her high dramatic talent, which she showed, in fact, in much of her amusing conversation, when she proved to be a granddanghter of Mrs. Henry Kemble, and a great-grand-niece of the still more famous Mrs. Siddons. She was, further, a most accomplished pianoforte player and singer, and she increased in farour with us every day of our acquaintance.

I may allow myself this opportunity of saying that I am myself profoundly affected with the importance of "the stage;" that is to say, of the dramatic method, alike for instruction and amusement. I regard Mr. Irving as amongst the greatest reformers of our age, for his energetic and, so far, successful efforts to redeem the cause from its unsilvoury admixture and surroundings. By way of illustrating the superiority of the dramatic method, take our Sunday-schools, and suppose that the children are set to learn their parts, in the beautiful stories, for instance, of Joseph or Ruth. Can any one doubt of the additional interest infused into the reading of Scripture? Suppose we go just a step further, and by a little dress arrangement bring the picture still nearer to the actual life. How few of the children would willingly absent themselres from such life-telling reading as this, and with how much more power would the Bilsle contents go home to 
them. But all this is the theatre, exclaims old prejudice; and, of all things, the theatre on Sunday! Is not this a prejudice very much akin to that against the organ in church worship in Scotland, which took its rise, as is, I believe, well understood, from the Catholic images that used to adorn the mere outer case! Indeed the dramatic or lifelike method might be beneficially extended much beyond Sunday-schools, and on Sunday as well as Monday. But I must admit that the modern theatre has drifted into bad ways that hardly fit it for the Monday, let alone Sunday.

In conclusion, there is one more of our pleasant company whom I must not omit, although not one of the passengers. That is our worthy and most efficient Captain Conlan. He had a rare aud rich fund of Irish humour, which stood us on many occasions. He was deroted to his passengers as well as his ship. Those of us who expressed opinions agreed that the "Orizaba" voyage, what between the captain and the ship, had surpassed, in comfort and enjoyment, all previous sea voyaging. 


\section{( 39.5)}

\section{PART II.}

GENERAL QUESTIONS OF 'THE COLONIES AND THE EMPIRE.

Qutrixg now the itinerary character and local detail which have been distinctively my subject hitherto, I propose to conclude with some remarks of a general kind, upon our A tistralasian group, upon Colonial questions generally, and upon the relations of the Colonies and the Empire.

I propose to discuss these suljects in a series of ten separate and distinct Articles, taking them in the following order :-

First, On the prospects for a still improved service of intercommunication between England and Australasia.

Second, On the amelioration of the Australian climate.

Third, On the great and newly developing trade in frozen meat.

Fourth, on the policy of the Empire's exteusion.

Fifth, On the socio-political principles of the Empire's Government.

Sixth, On the question of freedom or restriction in trading for the United Empire.

Seventh, On Intercolonial Federation, or the federating of natural Colonial groups into one government. 
Eighth, On the political unity of the entire Empire.

Ninth, Suggestion of a Monarchic-Democratic Peerage of the Empire.

Tenth, The Mount Morgan Gold Mine.

\section{ARTICLE I.}

OX TIIE PROSPECT FOR A STILL IMPROTED SERTICE OF INTERCOMMUNICATION BETWEEN HOME AND AUSTRALASIA.

Wriex I boarded the "Orizaba" off Adelaide, and was introduced to a style and convenience of passenger accommodation, and to sea qualities, speed, and so on, such as I had never experienced previously, and perlaps, in some respects, had hardly dreamt of, it seems rather a bad turn of mind that, after getting used to such luxury, one should firce about upon the perfection of yesterday, in order to convict it as the imperfection of to-day and to-morrow. But such is human nature under the ineritable doom of progress. Gratitude in progress is, like that fueling in more usual ways, a lively sense of what more is to come.

When our gallant ship, at her thirteen knot speed, carried us so easily, pleasintly, quickly, over temperate and tropical waters, now forcing through the head wind by her powerful screw at but little reduction of specel, and again, in the calm and leat, creating for us the cooling lueere by her own rapid motion, some 
of us might even regret that so pleasant a time must, at such rapid pace, be so soon ended. Even thirteen knots speed makes our world seem small by the rapidity with which we are plunger out of one climate into another, and with which we daily rmin down degrees of longitude by the half dozen, in our daily race either to meet or to follow after the smin, not seldom shortening or lengthening the day by as much as a good half-hour. But none the less is one aware that well on to twice this speed, and in vessels even still larger and more elegant, has leen already attained on other lines; and the question maturally occurs whether the rast commercial derelopment now being realised in Australasian business can be any longer regarded as second to anything in the ontside interests of our country.

Indeed there is something inexpressibly inspiring in the idea, that even with the present attainments in maritime intercommunication, the Australian passage might be made within three weeks, either rii Gibraltar and Suez, or round the Cape. When France accomplishes her grand canal from the Chamel to her "French Lake," which is surely also one of the needs of the day, we shall considerably diminish even that brief time. If II. de Lesseps completes his second grand canal scheme by 1890 , as he still hopes, here is a third which, in the comparison, he has no need to despise. But as speed is the first consideration now in our locomotion, and as water is an obstacle far more serious than air, the question arises whether a great ship railway is not the more suitable to the other alranced conditions 
of the case. Besides the leading consideration of speed, would not such a viaduct be more promptly made than the other, and be less costly in both the required area and the required money? If Paris is ever to hope to overtake London, and to retrieve her old position as the capital of civilisation, it will be by means of such a line, whether viaduct or aqueduct; and, if II. de Lesseps constructs that also, he must be ranked as beyond ordinary human nature. And, finally, when South A ustralia finishes her 'Transcontinental Railway, and there follows that possibility of modern progress, perhaps withal no great distance off, namely, a through line from London to Singapore, it may be possible, for any at least to whom such mad fury of pace is an object, to reach Adelaide, or even Melbourne, from London within ten days.

In these bestirring remarks, one of my objects is to prepare our Australian shipping interests for what may come upon them, perhaps with disconcerting suddenness, by a due realisation of the Mount Morgan Gold Mine. Those who recollect the effect at Home thirty-six years ago, when Ballarat and Mount Alexander were realised, may form some idea, albeit probably a faint one, of what will follow upon Mount Morgan, in conjunction with the actual effect upon the world by the instreaming millions of gold. This is a question chiefly of transporting to the faroff Antipodes a great multitule of persons, quickly, comfortably, and economically, in the great ships of to-day, and the still greater of to-morrow.

One point that particularly struck me regarding, 
for instance, our fine "Orizaba," that the spacious and elegant saloons and drawing-room, and the amplitude of deck, were rarely more than merely sprinkled by the cabin passengers, and that very many more of such passengers could have been taken, and quite commodiously distributed there, if the dormitory arrangements had been less exacting in respect of space. Could we not, for instance, go hack to the small cubicles that contented the Greeks and Romans for the eight hours of night, in view of the compensation of sixteen hours of roomy al fresco life of the day? The contingency of "liatches down " in a storm, and of the still adequate ventilation and endurable condition of a crowd of passengers in such emergencies, are, of course, of the very first consideration, when one would contemplate any such great rearrangement of the Australian royage. But, taking things altogether, as it seemed to me, the "Orizaba" might liave carried almost as comfortably, still more swiftly, and, most important of all, much more cheaply, a thousand instead of a hundred cabin passengers.

One more of interesting prospects let me allude to, and one perhaps of no remote character. I believe it to be well-nigh certain, from what I heard while on the spot, that Melbourne will invite a visit of the British Association, probably for either 1892 or 1893 . The time of year selected for this great science meeting will likely be either the first or the second week of October, when the country is covered with the beautiful bloom of spring, and when as yet even the more northern 
and tropical Colonies, to which the risiting will 110 doult be extended, are still under a pleasant or at least a tolerable atmosphere. Br help of such ample notice, by the attractire facilities of such a passenger transit as I have sketched, by all the marvels of Momt Morgan, and of a natural history almost still in the regions of mystery, the tide of passencers may be unprecedented, including, no doulit, many high personages of our country, possibly not excepting eren the rery highest. The finest ships, like the fiuest hotels with us of late, will then carry the day. And so, $O$ ye rival London shipping companies, lnok out! Te must hope that Liverpool is not permanently to head your. Let me remind you that two of the latest built steamers of the "Inman" Liverpool and American line, the "City of New Tork" and the "City of Parje," are each of 10,500 tons, with an attained maximum speed of nineteen lnots an hour. Prior to these great twin sisters, the palm rested with the Anchor Line's ss. City of Rome, of $8: 300$ tons. The race, howerer, nnce begun, goes on vigorously, and Messrs. Ismay \& Co. are now building two vessels, of about 10,000 tons each, of improved lines, calculated for still greater sjeed. Let me ardd. ly way of further incentive, that a speed of $23 \frac{1}{4}$ linots an hour lias been attained by three torpedo hoats just completed for the Incian Government. They were built by Thorneycrofts, and their speed testeil recently (November, 18ss) in the Thames ofl Gravesend. In 18:2, four more years may possibly show an improrement eren upon all this. 


\section{ARTICLE II.}

ON THE AMELIORATION OF THE ALSTRALIAN CIMMATS.

IT has often been remarked that, but for the alternation of Australian drought, Australian progress would be alike beyond all precedent and all concurrent comparisons. The country is mostly ready for immediate use, and the powerful sun, in his usually cloudless sky, will grow anything with minurpassable speed, if tempered and abetted by adequate moisture. The flatness of the interior seems the chief cause of this unfavourable fenture. The rainchargecl clouds, meaught by inlaud mountain heights, sail on to the surrounding seas, discharging the needless water in that quarter, instead of upon the toothirsty gromd. At the height of Australia's great periodical drouglits regetation is all but arrestert, and domesticated animal life, in many parts, is hel $1^{--}$ lessly sacrificed in a horrible wholesale. The latest drought of this description, which, after a very general reign orer Australia of alout three years, expired lut two years age, lost to the comntry twelve millions out of albout fifty to sixty millions of slecep, "besides much cattle."

One of the many peculiarities of this most peculiar. of countries is this intermittent rainless interval. If the evil be not obriated in some way by the progress of art and science, the rapid growth of the country's interests ever supplies a more and more crowded field of victims. But all the Colonies thus affected have latterly been untiring 
in remedial application, chiefly by means of irrigation. Private effort has followed, in many cases has preceded, that of the Government. The numerons great creek beds are being dammed up, and artesian boring is extensively and successfully undertaken. As regards the latter, for instance, one of the very latest cases is thus reported from the far interior of New South Wales: "A splendid supply of artesian water has been struck at a depth of 823 feet at Tambo. The water is overflowing the surface, and the supply is improving."

The great business of tiding through even years of drought ordeal with the great flocks and herds of the interior is seldom very dangerous, if there be the manifold resource of water. Hy friend Mr. Wagner, who is further alluded to in connection with the great Mount Morgan Mine, gave me an illustration of what could be done by this sole resource towards securing safety to squatting interests. Having joined some others in the purchase of a great pasturage, with a multitude of stock, in the northern part of New South Wales some eight years ago, the first few year's' results of what I may call umameliorated squatting, involving the partnership, as it did, in $£ 30,000$ of loss, instead of expected profit, produced that energetic despair which usually precedes success. As the total failure of local water had been the chief cause of loss, so the securing of that element became the chief aim of the series of "improvements." The large creek or river the Namoi, which, although only itself an internittent stream, hanl chains of large deep holes 
or reaches of water which were never empty, passed at forty miles' distance from their station. But a creek bed, which wound through their own run, touched a point in its course within half a mile of the Namoi. On this river at this point a steam pumping engine was erected, with a pipe for the half-mile of about eighteen inches in diameter, and at the beginning of each summer the smaller creek bed was duly filled with water from the larger. All this was accomplished within an expense of $£ 10,000$; and the happy result was that, during even that latest and perhaps severest of Australian droughts ever there experienced, not one animal was lost throughout its continuance.

Such an example as this, together with countless others, have aroused a very general attention to such obvious remedies. Nor is the advantage merely economic in regard to the live stock, or even, in further extension, to the irrigation of crops. The climatic amelioration and the sanitary advantages are at least equaliy important. The too-well-known hot winds, so prevalent during midsummer at .Ielbonme, because they pass over a long stretch of desiccated interior to the North West, are tempered at once by a good shower of rain. "Sturt's Desert," beyond Cooper's Creek, where the intrepid traveller had nearly ended his days, is supposed to be the fertile factory of these winds, when its vast area is, as Sturt found it, a perfectly waterless Sahara. But, in the odd contradictions of Australian climatology, where Sturt found this hopeless desert in 1845, Mac Kinlay, in search of Leichhardt in 1862, was as 
nearly overwhelmed with water, the wide and deep creek beds being filled up to their very brims, and not seldom hy five or even ten feet higher, with the whole country running with water, and for a time progress through it only possible by refuge on the very top of the backs of the camels with which the party travelled. Melbourne, we may be sure, had but little of hot winds that year, but I perfectly recollect that the summer of Sturt's visit, that of 1844-5, was one of unusual drought and hot wind in Tictoria, as was another six years later, whose culminating day has since borne the distinguishing title of Black Thursday. That day was the 6th of February, 1851, and I recollect this later occasion even more clearly than the other. The destruction of property over the Colony was unprecedented and enormons. But the accumulated precautions since taken render now the recurrence of such a calamity impossible.

\section{AR'TICLE III.}

THE GREA'T FRO\%EN MEAT TRADE OF ALSTRALASLA.

'The great resource of curing or preserving the sulplus meat of these pastoral Colonies, so as to fit it for the limitless market awaiting it at Home, came early before the colonists. I recollect this trade of the future struggling into its first existence in Mel-. bourne and Geelong during the year 18.4, when, 
after two or three preceling years of hat husiness, sleep and eattle had fillen to so low a mice, that the hest market for the time was to remicer them into tallow. The alternative resource of curing the meat for food for the Home market was concurrenily tried, and what passed as "a good :mmount" in those days of small things was sent Home, expecially of good colonial beef, packed, slightly silted, in strong, tight harrels. Not much came of all this. No one, I think, made a profit of it. 'The arts of a trade of delicate manipulation like that are not acquired at once. It was superseded by the rise of live stock prices with the return of good husiness times beginning in 184.;. In these attempts the New South Wales people participated, and were even a year before those of Port Phillip.

When flesh meat began to get once more superabundant a few years later, the mode in faronr this time was that of packing the meat in ice-a rery risky as well as costly methou, for, if ly any unforeseen accident the ice ran out, the whole stock had to be at once thrown into the sea. It was reserved for science to show that all this might be ensily accomplished without any risk, and almost also without any cost. Nature supplies free and rearly to our liand the chief materials. Air is compresect. The heat thus created is cooled by the ser. The cooled compressed air is then released into an airtight chamber containing the meat, and any required degree of cold is secured.

I have no record as to when exactly this new system began, or where. It was at work in Aus- 
tralia some time before appearing in New Zealand. Amongst the earliest in the latter Colony was Mr. Gear, of Wellington, who, about six years ago, began on a modest scale to tin the meat, and as a collateral branch to institute the newer freezing system. He sold his interests to a company, and this concern, as I have already stated, has considerably extended operations. Only three years since did Christchurch take up this trade, of which it is now the acknowledged head. The Belfast Works, where this start was made, are about eight miles outside the city, and there is already an energetic rivalry, which promises a trade upon a scale which, as haring arisen so recently, is probably much greater, present and prospective, than our general public have any idea of.

I am favoured with much of my later information from my intelligent fellow-passenger per "Orizaba," Mr. Snowdon, who returns from a New Zealand visit made in connection with large interests in this new trade. I am further indebted to this friend for turning my attention to a most practical letter on the whole sulject, written so lately as last September by Mr. Alexander McHardy, sheep farmer of Blackhear, New Zealand, who went to England in the present year, 1888, with the object of improving the Home arrangements for the sale of frozen meat.

The Colonial flockmasters, or their local agents, or local buyers, have had some reason to be dissatisfied with the results to them of the earlier inauguration of the great meat trade. The IIome butchers, acting in the wholesale way, have, as the old story of 
hminan nature, uniformly preferred their own interests to those of any one else. Account sales have been returned from London at 33.4 . per pound, which left only the odd fraction for the price to the Colonial grower, while the 100 per cent. upon $8 \frac{3}{4} d$. paid ly the consumer was supposed to have passed into a liocuspocus, which defied impertinent actuarial investigation. This was merciless at least, if not illegally dangerous. But the professional mercilessness of butchers excluded them from the jury-list of early England, and how can they be even superior to other men now? It is to be hoped that none of these particular butchers, with so much else upon their consciences, were parties to the scandalous trick, which seems to have been quite common in some quarters, until threatened with the law, of regularly ticketing River Plate mutton as New Zealand, the quality of the latter being always markedly superior. The River Plate, in fact, is a most formidable opponent; but, although its carcases are large and well put on. the quality of the meat is inferior, as the nature of the grass seems unfavourable to good flavour.

When I heard these various complaints as I passed lately through New Zealand, I predicted that the complainant's turn would soon come. He hat only to do his article justice, not merely by its quality, but by having it always, in regular and adequate supply, in its market.

This end has already come, accelerated, no doul,t, by the reaction of business in New Zealand, which has at last begun a decidedly prosperous development. The butchers cammot get their full possibjili- 
ties of profit without adequate quantity, and they camnot get the increased quantity without advancing the price to the grower very considerably above his starration allowance of $\frac{3}{1} \pi$. net per pound. That price, even as a casual minimum, is now wholly past. The latest agreement which I have noted allows him $2 \frac{1}{4} d$. , and Mr. Snowdon tells me that the Colonial market is already so strong, that even that price will not now be generally accepted by the flockmasters. Within only the last six months, he salys, the price of the net carcase of a fat sheep, of 56 to $60 \mathrm{lbs}$. weight, trimmed and ready for freezing, is up from $8 s$. or $10 s$. to $16 s$.

The pace of this trade may be judged by that of the Belfast Wrorks, where already the operations have reached 300,000 sheep carcases a year, hesides some considerable business in bullocks. The Company are making arrangements for twice that quintity next year. Although this is the lingest individual scale, yet there are other like establishments at Dunedin, Tellington, Napier, and I think one or two other places in New Zealand, besides other's in Australia. The former Colony bids strongly for eventually the whole of this great trade, because she can at once breed more rapidly and produce the letter quality. Mrr. McIInily, with the skill of a man who is master of his own husiness, throws out various hints towards " finish" in the set out of the carcase, by which it looks better in the eye of the buyer. The kidners, for instance, are usually taken out as " tit lits" for separate disposal, but the fat should remain for the "filling-up" effect. The 
kidney trade, by the way, is one of the curinsitien. Ther are packed in such handy articles as wh onedozen brandy cases, said to be still very plentiful in "Coffec Palace" A unstralasia. In their fro\%en state they are as hard as pebble stones, and might stand a sond deal of the hammer. In some everlastingly Greenland climate they might even be ent and polished, with a fine pebbly interior.

The total New Zealand shipment for this yenr camot be much short of a million sheep carcases. What it might rise to during the next few years may be difficult to calculate, seeing it depends on varying contingencies. The fact that, as Mr. IICInarly remarks, the favourite age in the sheep is no more than from one to two years, the days of "fiveyear-old mutton" having now passed away, is favourable to enormous possibilities of supply, while the advancing price will lead to a much quicker breeding system than there was any oscasion, or temptation, for under the low prices lately reigning. New Zealand has now not very much short of twenty millions of sheep.* I am not qualified to predict how many millions she could yearly export out of such a capital of stock, and yet maintain or increase the fund. Perhaps more experience is required to decide this important question.

* The number of sheep in the various Australasian Culunies, on 1st of April, 18S8, was no less than 96,462,0:38. New Sonth Wales had 47 millions, or nearly ono half; Victoria, nearly 11 millions; Queensland, 13 millions; Sontl Anstralia, alout 7 millions; West Australia, 2 millions; Tasmania, one and a half millions, while New Zealand harl as yet lut $1,5,2,36,000$. 


\section{ARTICLE IV.}

ON THE POLICY OF THE EMPIRE'S EXTENSION.

I THIxк that I may venture to say that, until hardly ten years ago, the policy of our Government had been one of opposition to the Empire's further extension. The expenses were one cause, for our Mother had wholly or chiefly to bear the expense, the Colonies not having as yet got into the halit of doing without her, as they had by no means the financial strength they have now attained. Another cause was a lingering feeling that the Empire's flanks were additionally exposed to possible enemies by every addition made to assailable territory.

Meanwhile quite an opposite view was being held in the Colonies, or at least the Australasian Colonies, brought practically in contact, as they were, with the French in adjacent New Caledonia. To our colonists, therefore, it appeared that the greatest safety to the Empire, and its best chances for complete freedom from foreign complications, lay in our amnexing to that Empire every uncivilised and unclaimed region throughout the vast area of our trade and colonisation. And this the colonists thought we might reasonably do, either negatively, from such areas being unclaimed by other powers, or, positively, from their being morally ours by the fact that it was our adjacent colonisation that gave them any economic value. So long as there was no such value, other powers were indifferent to these areas, but, when the successive contact of our advanc- 
ing settlements gives them that value, other power:s are then alive with interest, and eager to share thr. spoil.

\section{Case of New Guinea.}

The case of New Guinea is our hest illustration, both from the magnitude and prospective inportance of the place, and from the fact that, in the complications attending it of late, nearly all possible principles or contingencies now affecting the Empire's extension arise.

New Guinea is so rast a country, it makes so prominent a figure upon the world's chart, together with its golden name and its fame as one of the sunny tropics, that one wonders that it should until quite lately have been so little coreted or eren thought of colonially, by any of the powers, including even our own Gorernment. But the truth is that early private colonising efforts, begun from Sydney as far back as 1864 , had come to so little good, the place being so far from markets, and so really unknown as to resources, that, until quite recently, every successive trial was abandoned. The only parties who had the courage and perseverance to stick to their work were the English missionaries, who, scattered over the eastern shores of the Gulf of Papua, made substantial way with increasing numbers of the native children. The earliest claim to New Guinea was made by the Dutch, who, in 182s, took jossession, but in a purely formal way, of all the western moiety of the great island as far as $141^{2}$ east longitude. They completed this merely nominal act by estab- 
lishing a small fort, which howerer, as well as, in a practical sense, all the rest of this business, was entirely abandoned within a very few years after.

The New Guinea question opens with us in earnest about fifteen years ago, when in the Australian Colonies on the one side, and in the Royal Colonial Institute on the other, the annexation began to be urged upon the Home Government. The " masterly inaction" of the latter enabled them for some time to beat off these disturbing enemies of the official peace. But the cry became at last so lond and so repeated, that the old Mother became uncomfortable. The roice from the Colonies got ever stronger for annexation, and the Colonial Office liad by this time so far changed its colonial tactics as to appear eren extremely attentive to the expressed wishes of colonists.

Meanwhile, that which alone was giving New Guinea any valiue as a colonial territory, namely, the near approach of the settlements of our adjacent Australia, was in full irrepressible tide until, a few year's ago, it had already extended to the furthest northern extremity, where Cape York almost touches soutl-castern New Guinea. It was, therefore, high time when, in 1883, Sir Thomas NeIlwraith, then I'remier of Queensland, alike on that Colony's and on the Empire's behalf, amexerl all unclaimed New Guinea, that is to say, east of $141 \mathrm{E}$. long.

Now follows a series of blundering which some fow years lience may be looked back to with blank annazenent. Sir Thonias may, perhals, be aceused 
of beginning the blundering, becanse he acted without that proper imperial authority which a course of telegraph might posilly have then secured him; and thus he exposed the Imperial Goremment to a very cruel alternative as between Imperial interests and their own amune pirnine; whicherer alternative prevailed, the result was that Sir Thomas's otherwise timely action was not endorsed.

Sir Thomas had assigned as his reasons that the possession of New Guinea was useful to the Empire, and especially to Queensland; and that its possession by any foreign Power would be disadvantageous in the same direction. Blunder number one has been alluded to, and we may regard as number two, that the Empire's real and full claim to the eastern section, if not, indeed, to entire New Guinea, was on account of that completed Australian settlement which had solely given to it its now commencing ralue. This, the best part of our carse, was in no way alluded to; lut, in the blundering that suceeded, Sir Thomas was utterly outstripped at the Colonial Office. There is a grim irony in Lord Derly's answer to Sir Thomas, to the effect that the atprehension in Australia that some foreign Power was alout to occupy New Guinea appeared to be indefinite and unfounded, when, only seven months afterwards, namely, in December 1sst, Germany formally annexed the northern moiety, including the magnificent tropical islands of New Britain and New Ireland. As if to perplex the case beyomil all explicattion, our Gorernment, two months prior to this finil 
climax, had appropriated only the southern moiety of what the Dutch had left in 1828.*

Of all foreign Powers amongst us, we probably the least object to the Germans. They are almost our second selves. We shall never be at war with Germany. Still, by needless delay and incredible negligence in this New Guinea case, we may have involved ourselves in future trouble, at least of a commercial kind. The German press has been lately in very bad temper on this question. We are accused by it of grasping everything for ourselves in this colonising way, and grudging anything whatever to others. Of course this view is natural where there has been no trouble taken to look at all sides of the case. Regarding the past of New Guinea, Germany has been simply looking on (if indeed, she has shown interest even to that extent), while we have been long and continuously preparing a harvest. But, as soon as the harvest is ripe, she steps in, and helps herself to the half of it. Not only does Germany seem wholly unconscious of anything unreasonable in this procedure, but-possibly to infuse some humour into the case-she even assumes to be in a pet at the Australian colonists for raising the question. $\uparrow$

* I am inclebted for dates and events here, as well as for much else, to that compentimm of ererything on its subject, "Gordon and Gotch's Australasian Handbook."

† Germany has more recently crossed us again with some almormal proceetings at Sianoa, of which territury the Germans, the Uniterl states, and omselves have, by arreement, mate joint prize. Germany hero, however, has been long in the colonial 
The position of Holland, if she does still claim Western New Guinea, after having totally alandoned it for sixty years, is hardly better thin that of Germany. Now that we have given possible or probable value to the part she had deserterl, she may possilly think to reclaim it. Probally it will nerer yield her a florin of benefit, as is the common experience in such colonies. Australasia had best make her an offer of money for it, involving an amount that could hardly be any comparative consideration to such an adranced and advancing section of our Einpire.

Our policy of making every country welcome to our colonial settlements, and on the same terms even as we give ourselres, makes our colonial extensions acceptable generally to all other countries. No other nation acts in this way. We might still, therefore, recover also, of course not now withnut a "consideration," this German New Guinea moiety which has slipped us. I have spoken of the Camary Islands and "The Rock" as a matter of exchange.

field, so that this is not another mere New Gininea catse. Well, Germany thinks fit to declare war against the nominal samoan king (surely the most fainéant of monarchs), and therenu.n she exacts helligerent rights, from which even the other two "1rotecting "Powers are not exempted. 'That is to say, that Samua, haring been appropriated as sarage, is now made war upun by the rules applicable to civilised condition. Australia might excusably cumplain, as, indeed, she has alrearly done, that snch foreign interrentions were a serious danger to her interests; for her shipping and contents might prsibly at any time be captured or destroyed mider surh mexpectenl and mutradictory proceedings. 
There is another spot, in another sea, which might, antithetically to "the Rock," but not incorrectly, be called "The Sand," which past accidents gave us, when there was no expectation of a great German Empire at its back door, and to which, on all considerations, it properly belongs. Another exchange here might get us back our purloined, may I call it, New Guinea. Lastly, our friends across the Channel might, for perhaps the matter of a better position in Egypt, where in any case some early change seems demanded of us, give up another batch of southern islands, which, without being, on a balince of accounts, of the slightest economic advantage to them, are not unlikely to be, in various ways, as regards our far too adjacent Australasia, only a permanent trouble to both France and ourselves.*

\section{ARTICLE $V$.}

THE QUFSTION OF FREEDOM OR RESTRICTION IN THE EMPIRE'S TRADING.

WuEN our Empire pulls itself together in that form of mnity which will give to it all the power and influenee in the world that is possible to its circum-

* The French Govermment, it is melerstood, intimated lately an intention to cease sending convicts to New Caledonia. This would certainly remove the strongest of Australian oljections, and prove a grateful concession. But, after that, what interest worth consilering rery mneh about, as regards New Caledenian commerce, would remain to France? 
stances, and which, I am assured, its people now feel to be, every day, more and more an imperative duty and obligation, the great question which heals this article will be opened almost at once over its entire area. I have elsewhere stated that preliminary tariff agreement, however much to be preferred, is not at all indispensable to Imperial unity, if for no other than this obvious reason, that, when politically united, we shall be no worse as to tariff diversity than now, while we are immensely better by the political unity; and the political unity, if accomplished, will have a powerful tendeney to bring about this comparatively secondary consideration of the tariff unity.

\section{First Attempt at an Economic Parliament of the} Empire.

The only experience we have to guide us as to the possible or probable result of a consensus of the Empire on this great trade question is furnished by the results of the summons sent forth, eight years ago, by the chief Canadian "Board of Trade" to the Chambers of Commerce of the Empire, to meet by proportionate representation in London, in order to discuss the question of the possible "improvement of the trade relations of the Empire." There was a general, although not an universal, acceptance of the invitation, and delegates from far and near were gathered together into an economic parliament, which certainly might claim to be one of the most interesting, not to say important, events of the kind which the Empire had witnessed. 
The meeting took place in February 1881, in the Westminster Palace Hotel, and was attended by a decided majority of the Chambers invited, including the Home Associated Chambers. As London was then without a Chamber, which, however, was established later on in that very year, the eight members assigned to the commercial metropolis of the world were not forthcoming, leaving London unable to speak her views. As I appeared as one of the representatives of the Melbourne Chamber, and took some part in the discussions, I may briefly here allude to what resulted.

No one entertained, from the first, a doubt about the real object of the Canadian movement. Canada, three year's before, had decided to pass from comparative freedom of trading for her labour products to very considerable exchange restrictions upon her own industry. She wished now to sound the prospect as to applying like restrictions throughout the Empire, with the effect of reserving each other's markets, and excluding or substantially handicapping the foreigner. There was a substantial protectionist force in the Congress to abet the Canadian view, coming cliefly, besides Canada herself, from the Cape and the West Indies; but the trading freedom of the Parent, supported as it was generally by the Home chambers, and by the decided majority of those of Australasia and India, carried the case against Canadian expectation, and thus led to Canada's early ceasing to take further interest in the very important morement which she had inangurated. That movement, therefore, dropped, and has 
not since been resumed. We learn litely, however, that a similar movement is now proposed, at the instance, this time, of the Dominion Goremment.

\section{The General Question as to the Empire.}

Perhaps we must now regard it as impossille, after so many years' experience, to hope that this contention will ever be settled by a purely economic argument. If a company of traclers were to meet for the purpose of deciding whether they should choose for their money one pile of miscellaneons values of the amount of $£ 20,000$, or a rival pile of like miscellaneous ralues of the amount of $£ 2.5,000$, it can liardly be doubted that even the most crotchety-minded of the party would never hesitate as to the choice. But evidently it is to be quite another matter, when we cunsider a pre-stage of our case, namely, those liatour dispositions which are calculated to produce the larger pile, as comparerl with those which are to produce the smaller pile of labonr-product. Economists from Adam Smith downwards have demonstrated orer and over again, and ench one clearer than the other, that a system of freedom of exchange must produce a larger labour product than a system of restricted exchange; and that to divert lahour, from the natural tendency which it has to take the most profitable channel, into a channel that is less productive, but which is made to yield profit by imposition of a ligher price, must surely result in the smaller product. But all this demonstration seems utterly unavailing to convince the protec- 
tionist, who shrouds himself in selections, partly of facts, partly of fancies, by which he has convinced himself that to be protected must be better than to be unprotected, that we should exclude imports that compete with or undersell our own producers, that we should get all we can out of our own soil, instead of buying the product of foreign soils, and that as the general rule we should reserve our own market for our own people, and not for strangers.

The fallacy in all this jingling of words is that it puts the minor interest in the place of the major, and the interest of the few in that of the many. Every society, in its individuals or classes, especially those of new countries and colonies, may be said to be workers or producers of some lind, and their chief interest is that no sections of individuals or classes amongst them be specially favoured at the expense of all the rest.

But, after these principles have been enunciated for a thousand and one times, we must needs, as experience shows, abandon them, so far at least as to the hope of any conviction they are ever to carry to the other side. There is, however, one better hope, namely, that of the increased influence of the parent, after the whole family have been united under one effective government. Hitherto influence and influential example have been somewhat the sport of accident for either side. Merchants are influenced to free trade by their obvious interests, through which they easily create and store up their ready arguments, much as farmers and manufacturers are influenced in just the opposite direction, and easily 
rear up a pile of the opposite arguments. Probalily most of our merchants, however convinced of free trade, would soon lose their logical sequences in an argument with a smart and well-practised protectionist, who would possibly smash them all round as effectually as the squire did Moses, by showing that "the concatenation of self-existences, proceeding in a reciprocal duplicate ratio, naturally tends to produce a problematical dialogism, which goes to prove that" protection is secure prosperity, and free trading is the ready road to ruin.

This parental influence, as I have said, will tell when the Empire in union comes to consider this question, and I have no doubt whatever that this influence, gentle, leading, guiding, will eventually prevail even to every Colony of the Empire. It is marvellous how the sense of being under one great government rids us of the small and the separative in our ideas. In speaking of inter-colonial federation I rentured to predict that, when Australasians felt that they were under one and the same colonial government, those small and separative tendeucies that resulted in such anomalies as intercolonial border duties, and at times all but border bloodshed, would gradually and even rapidly die out. And much more so, let us hope and trust, will it be with the United Empire. 


\section{ARTICLE VI. \\ ON THE SOCIO-POLITICAL PRINCIPLES OF THF EMPIRE'S GOVERNMENT.}

Trie only point that is in question here relates to the government of the tropical parts of our Empirethose countries where our countrymen either cannot or will not labour, or where, even if willing, it is undesirable, on public grounds, that they should labour, as the result would be injurious and even destructive to the race; and where, therefore, if such places are to go forward to their economic possibilities of destiny, it must be by coloured labour.

Then comes the question as to the form of Colonial Government for such countries and their indispensable coloured populations. If we give them constitutionally free administration, that will mean either the supremacy of the few of white race, and a practical slavery to the many others; or it may mean, as the alternative, some egregious political fiasco. The question, then, is, should not such countries be always administered as Crown Colonies?

One might have supposed that, as for instance, in the case of Queensland, the socially and numerically overweighting southern section of her great area might readily control the northern; that in short the former might act towards the latter as the "Crown " or Home Government itself might do, so as to check those legislative enactments, or those practices, which have the objectionable tendency. Aud, no doubt, some such action might be expected 
if colonial politics were not liable to extremes of views and action, which may go very injurionsly indeed beyond all that was necesiary for the precise object in question.

This was very clearly seen in the case of Quecnsland herself. The political parties ranged themselves. inter uliu, for or against " Kanaka" labour, and the acrimony of party, together with some difficulty in "dratwing the line," soon made the Kinnaka, or diurklabour question one for the entire colony, tropical or non-tropical, with the consequence that, for an inexorable party triumph, the sugar and other plantation interests of Northern Quensland were sacrificed and nearly ruined, with the grossest injustice to individuals, and with serions injury to the country.

\section{The Tropical Settlements to be under Croun Government.}

The principle, I think, should be recognised as general for the Empire, that all tropical territory, depending for its derelopment upon dark labour, should remain permanently under Crown Government. It has been suggested that, after Australasian federation, tropical Australasia may be left to the Federal Colonial Government, as in itself an approach to that imperial breadth of basis which ensures the disinterested and the equitable. This is not to be denied, and it may arise for consideration upon the fait accompli. But in the mean time let the Imperial Government retain what it has, and, further, initiate 
a movement to get back what it has inadvertently let slip, more especially as I feel sure that, with some good management, this result will not be at all difficult of attainment.

Lord Knutsford may be said to have inaugurated the right course by reserving, from lat. $26^{\circ}$ northwards, the tropical parts of the great territory of West Australia. In any case, indeed, the handful of colonists at the south-western angle around Cape Leeuwin, could hardly have been conceded any more for the present. Later on, with the Colony's increase, there may be some still further extension of territory northwards towards true tropical conditions, which, in Australia's peculiarly dry climate, may pass eren a little inside the geographical tropical line of $23 \frac{1}{2}^{\circ}$.

As to the question of recovering, for Crown government, the northern or tropical territories of South Australia and Queensland, it is certain that, as population increases in these parts, there will be an irresistible movement for separation from the control of the respective southern territories, with their climate, their vocations, and their interests generally so different. This movement is already at work in Queensland, and by-and-by it will come on at Port Darwin also. This is the Home Government's opportunity; and there might be a good effect towards the end in view by some understanding that separation would readily be granted on agreement to the Crown Colony condition. Every flockmaster and planter, I doubt not, would, by the instincts of his interests, agree to this condition, both because it secures him from the 
uncertain political economics of a working class of miners, which may he, numerically, political master of the situation, and because lie is thus likely, and in ways and measures quite free from invilious suspicions and precautions, to be, almost by infinity, better supplied with his indispensable columed labour.

\section{ARTICLE VII.}

ON INTER-COLOYIAL FEDERATIOY ; OR THF TYION OF NATURAL COLONIAL GROUPS IN'TO ONE SUBIMPEIRIAL POWER AND GOVERNMENT.

\section{The Australasian Case.}

So far as theory is concerned, the very great majority of Colonies and colonists have, I think, miloubtedly pronounced for Inter-colonial Feleration, the object being, of course, as with the further question or step of the Unity of the whole Empire, a sulject I am next to deal with, to attain the greatest power and influence, together with the greatest wisdom of government, possible to all the circumstances.

The only difference of view which I have met with, on this inter-colonial federating question worth noticing, is one which is still entertained by some few colonists, who included in their numler the late Mr. Foster of Sydney, ex-Premier of New South Wales. Mr. Foster dirl not. I think, from 
my recollection of a discussion with him on the sulject when he was in England, either deny or ignore the benefits of the federation abore alluded to ; but he had the impression, or, call it, the suspicion, that a united and strong Australasia would have a tendency to depart from the Mother more pronounced than in the comparatively helpless cases of individual colonies. In my late Australasian tour I met with some, although comparatively few, who still held that view. It was an entirely loyal opposition, if it amounted to opposition, prompted by the fear that such a step might, in the way assumed, prove unfavourable to the cherished unity of the Empire.

\section{Guidance of the Canadian Case.}

This is a very important consideration, if there were any reality in its riew. Happlily we have, in the case of the Canadian Dominion, a realisation which is at entire variance with that view. No one can now doubt that our federated North American Colonies are in a position which is in every way letter, alike for the Empire's cause and for themselves. The Canadian Dominion, as such, in comparison with the preceding individualism, is at once more loyal to the Empire, less troublesome to the parent Government, less uncertain in its political procedure, and more mutually amicable and politically contented amongst themselves. 


\section{Erceptional Cases: Queensland.}

Indeed, had Mr. Foster lived until now, he might have seen, in his Lustralian group itself, reasons for conning to quite an opposite conclusion. An occasional fractionsness of political temper which has been shown of late, particularly in Queensland, would certainly, as I think, disappear in an Australasian Dominion. I am not able to say by what accidents of the past this Colony, as represented in this matter by one of its political parties, took a "national" or independent direction. In this respect, as a Colony of Englishmen, it has differed from all the other Colonies of Englishmen of the group. I therefore attach the less importance to the indication. This latter riew is strengthened by the fact that the MIcIlwraith party, which leads the socalled Nationalists, is associated with the squatting and planting interest, which, as the rule in Australia, is the most loyal of all. The Griftith (anti-nationalist) party goes with the "democracr," who, if there is any real or supposed separative or repulilican tendency, may he expected to represent it rather than the other.

Again, in this direction of guidance as to any depth of reality in this "national" movement, we have the motto of the said party, "Alliance, not Dependence," the final word indicating. now at leatst, and for years past, an entire misapprehension, as the views at Home, alike of Goverument and people, are for the unity of the Empire upon a perfectly equal political basis. 
But, even if this separative feeling be really so much of the mere surface as I find reason to assume it to be, it may still have its inconveniences at times, in the present political individualism of Australasia, and in particular at times when this national party of Queensland happened to be in a majority in the political representation of the Colony, upon any question arising that might be held to touch the party interest. And, no doubt, this has been one cause, although not the sole cause, of the movement in opposition to the late appointment of Governor, by which, as now undoubtedly appears, the Colony lost, to say the least of it, a decidedly super-average man. Another case of like local party bearing is the unexpected refusal of Queensland, at the last moment, and after preliminary assent, to join all the others of the group in the naval defence arrangement with the parent government.

Nor must we ignore that this step as to the Governor, unusual, or rather unprecedented, as it was, has been partially supported by some of the other Colonies. And thus we see how delicate a situation may at times arise for the Imperial Government, which, in conceding to its offshoots the constitutional political freedom which itself enjoys, has given them a practically free hand. But Victoria has, I am sure, spoken the true colonial and loyal fecling of the group of our brother Englishmen at the antipodes, as indicated first by the deliberate refusal of the Premier to join in supporting Queensland, and afterwards by the $\Lambda$ ssembly, when Sir Bryan O'Loughlan pressed the question to a division, 
by such an almost unheard-of majority nowadays as 59 to 3 .

This question of appointment of governor is happily now at rest, Queensland having loyally accepted the second nomination. A suggestion hat been thrown out in what seemed an "inspired" * direction, to the effect that the Colonies might arrive at some special understanding on governor nominationships. If that meant any form whatever of prior submission of any proposed governor to the ministry of the day of any Colony, it appears to me of utterly mischievous tendency. The frequent acrimony of colonial party is enough to prove this. A governor who has come in under the auspices of one party in power may be all the less welcome with the next. I am glad to see Lord Knutsford's recent firm langnage on this vital point. But all Australia knows well enough that this Queensland embroglio was fundamentally Irish; which indeed only emphasises my remarks in the postscript to this article, on the importance of colonial Irish sympathy in the canse of their IIome countrymen. The real point is not the demurring of colonists at some Home appointment, secing that liberty of speech and opinion eamnot be controlled eren on that delicate point, while the selections themselves have not always been the most advisable

* A tolegram of January says that "tho Governme of South Australia remarked at a public dinner, with corlial respunse, that the colonists did not wish to reduce the reponsililities of the Home Government in appointmont of Governors. IIC advised a delegation of colonists to settle the whole matter." 
(a matter, however, it is only fair to add, rather of the past than the present). The point lies in any preliminary juggle with a Colony as to the appointment. With due care on the Home part, and particularly while the Irish question lasts, this kind of incident is not likely, I am sure, ever to occur again.

The Imperial Government has usually, for the last thirty to forty years at least, met colonial political emergencies in a generously conceding spirit, where concession was possible in principle. The Crown loses nothing by this course, which always falls with good effect on the occasional bluntness or roughness of procedure of Colonies. It exemplifies the French saying of "reculer pour mieux santer." I do not for a moment doubt that an Australasian Dominion will work as satisfactorily as that of Canada. Whaterer any party in Queensland may at times dream of, even that Colony's dreams are always on behalf of a united Australasia; she never seriously indulges in a dream of any kind upon her own separated and individual behalf.

\section{Modes of Procedure towards Federation.}

With these preliminary remarks, let me now approach the question of practically carrying out Inter-colonial Federation. When difficulties present themselves, we must keep in view preponderating advantages. When these latter create and maintain the will towards unity, there will always be a way 
through the difficulties. One very great difficulty, however, is to put the machinery in motion. Conferences have sat on the qucstion for many years past, and have resulted in nothing, - a strange result surely, with its positivcly awful waste of tme, in so profoundly important a question, in which, too, all seem to have been agreed in principle.

\section{Chief Difinculty that of the difiering Tririfs.}

But the "Feteral Council Bills," which the different. Colonies lare lately passed, promise to be one effective begimning of this morement; and now we are to confront what is perhaphs the only real difficulty apparent in the case, namely the Tariff diversity. Those Federal Council Bills, let me adl, by no means relate to complete inter-colonial fecleration. They are based upon a permissive Inperial Act, and were chiefly intended for unity of anthority in certain civil and criminal procedure. So New Zealand, as so far off, was not included. Nor was the Tariff question incluled, because, as my friend Sir James Garrick, late A gentGeneral for Queensland, informs me, previous private discussion had convinced the different parties of the hopelessness of agreement there. This latter incident may help to show that the Tariffs are the real difficulty in the federative conrse. But, none the less, those Federal Council Bills indicate a good beginning. 


\section{Great Advantages from Canadian Federation.}

In conversing on this federative subject with my distinguished and experienced friend Sir Charles Tupper, who took so leading a part in Canadian federation, I find that much the same diversity of Tariffs prevailed amongst the Canadian as now amongst the Australasian Colonies ; for Nova Scotia, for instance, like Nerv South Wales, was favourable to free trading, while the others were, more or less, protectionist. Nevertheless, the different legislatures were swayed into federation by due consideration of the vast resulting advantages. And thus they were induced to surrender the Tariff question, as well as the others, to the Federation.

One of the most prominent of these great resulting advantages was the financial. As Sir Charles went on to point out, Canada's financial credit rose to a height that seems well-nigh incredible. He illustrated this from his own personal experience. About a quarter of a century ago he had occasion to negotiate a loan of $£ 400,000$ for Nova Scotia, which was then perhaps the best accredited Colony of the group in the London market. The only offer he could get was 95 per cent. from Messrs. Baring Brothers, for a 6 per cent. stock; whereas, within the last six months, he had sold by pullic tender in London, and through the same agency channel, $£ 4,000,000$ of the Dominion 3 per cents. for a rather higher price! Of course, the whole of this vast advance of value is not due to specially Canadian circumstances, seeing that the Colonies generally 
have of late been advancing in favour with Home investors, while the Home money market has been progressively in more abundant supply. But we may well attribute quite the larger moiety of the adrance to the Canadian political changes in question.

\section{IHou the Austrulasian Turiff Diffeculty may be met.}

I did not fail, in my interviews with premiers and treasurers, during my late Australasian tour, to urge in particular this great financial advantage. But, having already touched upon that sulject in its proper place, I now pass on to the Tariff difficulty. I do not underrate it, as my above allusion may show. Indeed I found Tariff antagonisms so sharp, that I came to the conclusion that, unless Tariff freedom were reserved to each Colony, the federation would linger undone, in spite of all the advantages. But, as was argued against me, can there be a united Inter-colonial Government with the Tariffs left out? What else, comparatively speaking, is there to govern? I do not see the question in that formidable light. I do not see what is to prevent the Australasian Colonies coming into complete political federation, with the sole exception of the Tariffs, which, for each Colony, may be left in the hands of a special Commission, in the view of being finally dealt with by each Colony for itself. My belief is that, so soon as these Colonies found themselves actually under one and the same govermment, with all the satisfying results of such a union, the 
Tariff question would begin to assume is far less hostile aspect, and within a very few years be entirely disposed of.

\section{ARTICLE VIII.}

'TIE UNI'TY OF THE BRI'ISH EMPIRE.

Definition of the Case.

Like my friend, MIr. James Service, late Premier of Victoria, who may claim the leadership in this question in his colonial group, I prefer the term Unity of the Empire to Federation. The latter signifies the supposed means; the former is the real object. Imperial unionists, however, have mostly come to the conclusion, that as federation, somewhat, for example, like that of the United States, can be the only mode of unity amongst Colonial societies, each with its own local self-goverument, we may as well go at once to the term "federation" of the Empire. We must leave the Colonies, separated and remote societies as they are, with that self-govermment which they now possess, so far, at least, as regards all local interests; but the question may still be, whether we camnot, withal, institute a union which may deserve rather the term "unity" than "federation."

I speak here of union between the parent state, and what are preperly our Colonies, or the emant- 
tions of our own people, such as the Canadian Dominion, Australasia, and South Africa. I do not enter upon the quite distinct question of such parts of our Empire as India, and other like sections, usually in tropical regions, which are occupicd mainly by races differing, in more or less extremes, from our own. But, doubtless, that is also a question to be dealt with in a completed union.

\section{Defects of the present Situation.}

We hare granted to all our chief Colonies the full form of "constitutional" self-goverument which we ourselves enjoy at Home. We can see better now than we probably did at first, that we should, along with this important, this decisive grant, have instituted some Imperial supremacy which, to be consistent, should have been also constitutional. We should, that is to say, have simultaneously instituted some conrenient form of executive for the Empire, in which there was due provision for the Colonies having always their due proportion. The leading Imperial questions miglit have been then easily sketched out, including the command by this executive of all Colonial, as well as Home, force, military or naval. All this might have been easily done at the first; and the Colonies would have since grown up under a sense of the Imperial supremacy, of which in its grand united strength, present and prospective, they would, doubtless, have been proud. Instead of this, they have been growing up under a sense of practical local freedom, which has naturally 
produced that instinctive segregative tendency, which we have latterly seen most strongly exemplified in Queensland, but also in other Colonies, as, for instance, by an occasional outburst in our otherwise loyal New South Wales, where already three successive generations have been born on the Australian soil.

That which was left undone we have now to do, and it is by no means so easy to do it now. But the question is now happily much studied both at home and abroad, and neither loyalty nor enthusiasm are wanting on either side. This feeling has arisen almost entirely within the last fifteen or twenty years; for, prior to that brief retrospect, with regard more especially to Home feeling, an indifference as to the colonial connection, which seerns now altogether incredible, was nearly everywhere the rule. As the result already of this new feeling we may, correctly, I think, say there is unanimity on the Home part for the most complete political unity of the Empire possible to all its circumstances. On the colonial part, there is substantially the same general feeling, but it is diluted or weakened, more or less, from the colonists having lived, for the last one or two generations, under a sky and upon a soil which were always practically before each separate people as exclusively their own, uncontrolled, at least in any every-day and practical sense, by anything whatever situated outside of them. 
Rt. Hon. W. II. Sinth on the Lnity of the Eimpir.

I could not give a better illustration of the complete change of feeling at Home, from the former apathy or indifference, in regard to the colonial connection, than the following telegraphic alstract of a public speech by the present Right Honourable leader of the House of Commons, early in last Octoluer. I may add that, from such a position, such language on its sulject would have been utterly undreant of twenty years ago.

"MIr. W. H. Smith, leader of the Honse of Commons, in a speech which he delivered at Gloncester, referred to the question of Imperial federation, and to the importance of maintaining the connection between the Colonies and the Empire. Alluding to the difficulties which were supposed to block the way against the establishment of a scheme of Imperial federation, he said that such federation had practically been already achieved, for, by their adoption of the defence scheme so far as it related to themselves, the Colonies had really become partners with England. The Colonies had in the past given ample evidence of their attachment to the mother country; and, as an illustration in point, he referred to the despatch of the Australian contingent to the Soudan. Mr. Smith said the Colonies were almost as the life-blood of England, and their future gave promise of such splendour, that he believed the time would come when they would prove stronger than the Mother Country, and supersede her as a nation." 
Ineritable Tendency of the Present Relations.

As these chief Colonies now stand to us, it may be said that neither party is bound to defend the other. There exists no doubt, however, that the mother would defend any, or all, of her children if attacked, either in her own quarrels, or in theirs, if they had any with foreigners, as Victoria, and, indeed, Australasia with her, might not impossibly have had with France lately, about New Caledonia or might still have with China upon the irritating Chinese Exclusion Acts.

But even already the separative feeling might be strong enough here and there to occasion opposite views and action. On the one hand, New South Wales, with surpassing loyalty, as being unasked, despatched a considerable force to help us in the Soudan, others of the group also offering the same. On the other hand, Queensland, her offshoot and daughter, and situated upon her immediate border, refused, at the last, by Parliamentary vote, as I have already stated, to come into an agreement to contribute towards naval defence, not only after all the other Colonies of the group had done so, but after the preliminary consent had been álready given through a preceding Queensland ministry.*

* At the election of May last (1888), which brought in tho McIlwraith ministry, there was much display of "nationality" banners, and about "Australia for the Australians." Sir Thomas McIlwraith, while indicating that ho intended to refuse for the-Colony the said contribution for the defence fund, male the statement, to me utterly incredible as from an 
Under the foregoing consilerations. I agree with a view as to the Empire's prospects which has latterly come into increasing force, especially since the Imperial Federation League has introduced system and logical sequence into this great question, - the view, namely, that the Empire will go on to inevitable disintegration, if left much longer in this non-united condition. My friend, Sir Charles Tupper, in my own hearing, at a late meeting of the Royal Colonial Institute, disputed the existence, or, at any rate, the dangerous strength of this tentency. Sir Charles, as at once the most experienced of colonists and the most loyal of felerationists, both interColonial and Imperial, must always, on such a subject, be worthy of attention. But he and myself, I may say, have both agreed, in discussing, more than once, this sulject, that the Dominion is peculiarly protected, in lier Imperial loyalty, by the fear of her being swallowed up lyy her huge neightbour. Every society, like each human being composing it, naturally clings to life; while to Canada a junction at present with the great Republic means

Englishman, with reference to an Empire of Englishmen, that he regarded this contribution as a tribute levied upon sulject Queensland. But withal, we must not attach too much importance to sudden popular demonstrations of this kind, which have occurred more than once in loyal New South Wales and elsewhere. Queenslani had been bitterly disappointed shortly before in the New Guinea affair, which was probahly the chief cause for the time of this unusually disloyal outhreak, and was especially irritating to Sir T. McIlwraith, whose timely action, if supported, wutld have landed all Eastern New Guinea safely in the Empire. 
death. Canada is no doubt distinctly swayed to the States by commercial interests; but as distinctly, and far more porwerfully, is she stayed where she is by the simple consideration of existence; "yea, all that a man hath, will he give for his life." If Australasia had some such great state as France or Germany alongside, we should perhaps be as devoid of fears for her as to the separative effects of time as Sir Charles Tupper is for the Dominion.

\section{Some Colonial Prospects, fanciful and otherecise.}

Let me add yet a word as to Canada and the States. Mr. Reverdy Johnston, the States ambassador some quarter of a century ago, undisguisedly claimed our North American territory, while Mr. Blaine, the other day, with a more adroit strategy, intimated that Canada would be welcome, but only as coming: with its people's consent. At the British Association meeting at Montreal, in 1884, a most interesting occasion in which I was happily able to join, I read a paper, the chief object of which was to institute a comparison, present and prospective, between the Dominion and Australasia. I was bound to assert that Australasian progress, under the conjoined circumstances of geniality of climate and a readyto-hand country, was, and would, for some time, be comparatively far swifter than that of Canada, with its colder climate and ice-bound ground for a large part of the year. But I had to go on to say, that the whole course of the world's civilisation has been a hitrdly interrupted passage from the warm climate, 
with its early and rapid advance, to the cold, with its deferred but solid and surpassing progress. Thus the "indigenous" Germans of contemptuous Tacitus already bid for the intellectual supremacy of the world; and thus the chill Canadian Dominion of to-day may not only eventually head A ustralasia, but also the great adjacent Republic itself, and possess that dominancy over all to the southward, which is already indicated as between North and South in the American Union. Canada, therefore, may have only to pursue, sufficiently long, "a waiting game," in order to turn the tables completely upon her southern cousins.*

\section{The Unity aimed at.}

Practically, then, we are in the position of the scattered sticks of the fable, which must be united

* Meanwhile the hoped-for course of Canadian amexation runs quite merrily in the adjacent Union. Only the other day, and since the above was written, Mr. Butterworth, member for Ohio, introduced a resolution in the Houso of Representatives at Washington, on 13th December, 1888, suggestive of the terms of invitation for Canada to join the States. If nothing comes shortly of thisfor why waste precious time? - I advise the Honourable meminer to try a still stronger step upon the supposably hesitating Canadians. He might, for instance, go on to name contingently, to the future head offices of the proposed new States, some of the present leading, and especially the troullesomely opposing; Canadians, with perhaps doutble salaries to loot, payable in the hardest of dollars. I suggest particuiarly sir Charles Tupper for the best berth going; for who knows what the effect might be, of so many prospective Almighty Inollars, upon the rell-known present loyalty of that leading Dominion statesman! 
into one bundle in order to give them their greatest possible strength. This is the question before the Empire; and attention has happily been called to it all over that Empire for nearly the last twenty years. The almost incredibly apathetic feeling previously held on this subject let us now pass over, seeing it no longer exists.

\section{Foreign View on the Question.}

I am here reminded of an article in a leading Paris newspaper, which I met with about ten years ago on this question of the unity of our Empire. By that time the movement at home had been sufficiently conspicuous to attract outside attention. The writer made the remark, surely all-significant to us, that if this movement went on to completion, there would be so vast a change ahead in the distribution of the international power of the world as to require a reconsideration of that subject.

\section{A Public Discussion in Melbourne.}

By invitation, while in Melbourne, I gave a public address on the subject of unity or federation, alike Inter-colonial and Imperial. There was a crowded audience, and the most satisfactory loyalty displayed towards the idea of the united Empire of our English race. Two of the audience, however, young men, and native-born Australians, dissented, and urged an independent Australia, which they regarded as a necessity, with all the differences, in climate and circumstances, from the Mother.

Now there is a habit in Melbourne, and many 
other places, of forming "Native Associations." These are not by any means, either in intention or fact, disloyal; but it is quite natural that some of the members, especially the younger ones, who are as yet the great majority, should be tempted, in the present non-united state of the Empire, to take up such views. Amongrst my fellow seniors in Victoria, as far as I can now recollect, the only opponent to, or unbeliever in, the Empire's unity whom I happened to meet with was my old and most able friend, Sir Archibald Michie, Q.C. In a note, dated 9th October last (1888), he says, "If I can find time, and can conquer the indolence incident to advancing years, I must have a tilt against your views on Imperial Federation, in which I do most devoutly disbelieve." Now, reversing the Sodom case, if in this matter there were the weight of fifty unrighteous Michies (I only mean "unright" in Imperial perception), this might be formidable opposition. But the minority of one, however otherwise distinguished, savours rather of the accident than the principle.

The most distinctive feature of the discussion that followed my address was a powerful speech of $\mathrm{Mr}$. Fitzgibbon, the able town clerk of the city, upon the exposed position in the world of such a comparatively small power as an independent Australasia must expect for a long time to be. He showed, by a variety of instances, the sad facility with which international differences cim be got up, especially where one of the parties may be weak as well as wealthy, and where perhaps national vanity, or 
special political considerations, were at work with an aggressor. Only a few years ago, Spain savagely attacked her own daughter Chili. Chili has since fought and mastered her own sister Peru, after a most deadly struggle; but she was not equal to her Mother, Spain, and had to suffer in consequence a most bitter humiliation.

\section{Some Reflections.}

It is to be feared that the peace and consideration which the Colonies enjoy under the æegis of their great Mother has a most deceptive effect upon that younger generation of the native Australian element, which, with all the enthusiasm and hopefulness natural to their youth and inexperience, look out upon the seemingly tranquil horizon of such a life. Let us suppose for a moment, that Australasia has seceded to-day into the romancing of such a life. Probably, within two or three years, if indeed so long an interval, China, with all the facilities of adroit diplomacy, wherever there is the will for it, might fix a quarrel with the new power, in revenge for the repeated mortal affronts of the Australian Chinese Exclusion Acts. In such a case the wcaker power might learn a sad and sore lesson from the cool atrocity of the race, and with incredible dispatch experience an incalculable barbarism of injury and outrage. Australasia, for yet a gooul many years, would be no more equal to match China, with all her modern armaments and her countless forces, headed probably ly Europeans, than she would be able to match her own powerful Ifother. 
My own impression, after visiting Australavia, agrees with that of Lord Rosebery, and not a few others, that although the unifying of the Empire, now that we turn to it so late in the day, may have its difficulties, including even partial apathy or opposition, yet that the strength of colonial loyalty generally is amply sufficient, if we go to the business in the right way and with the due diligence. Let us, then, consider as to the mode of procedure.

\section{Consideration of Methods for uniting the Empire.}

I have already said that two things are fundamentally necessary for a united Empire, namely, first, that all the forces, of whicherer kind, be under one executive, and that the Colonies be proportionately represented in that executive. The form of executive, therefore, is the question.

For some years after the sulject was taken up in the Royal Colonial Institute, two modes of an Imperial executive, or government, were in more or less favour: first, an extension of the present socalled Imperial Parliament, so as to malie it constitutionally Imperial by proportionate inclusion of Colonial member's; and, second, a great federative body, elected proportionately from IIome and Colonial elements, and dominating the present Home Parliament-indeed, putting it, in principle, on a common level with the Colonial Parliaments. There was an attractive theoretical perfection in this plan, and it had not a few zealous advocates. Let me offer some remarks upon both plans. 
1. Granting eren that the Home Parliament would be willing to receive such an influx as some two hundred or more members from the Colonies, it seems to me utterly hopeless to induce the colonial populations to take a step so costly and disturbing. They could never dream of sending so many of their most prominent citizens so far away upon legislative duty. There must be some much simpler and less costly mode of an executive than that which is to be drawn from an impossible Parliament of this lind.

2. The other mode is even still more difficult and less possible of accomplishment, because, in addition to some like strain as to numerical membership, there is the immense difficulty, in every great and old society, and in ours particularly, of the change of political form. Only imagine our present Lords and Commons introducing and fighting over a Bill which is to impose orer themselves respectively a dominating body, whether a federal assembly or anything else! We might all possibly approve the step in abstract principle, and so on ; but the step, none the less, would never be taken.

It is perhaps our special case to have effected very great political changes in the popular or democratic direction without any change in point of political form. Thus, keeping within the lines of the constitution, we have made all these changes with comparative case, and with, comparatively at least, slight opposition. The late General Peel, on the occision of some allusion to the possibility of an early repululic in this comntry, in connection with its democratic progress, made the energetic reply, that 
the Thames should run with blood ere that came about. The gallant general is said to liave afterwards regretted so strong an expression. He might have still mure regretted it if he had seen that his indiguation and his fears were alike rain. The change of political form is too violent for any possibility of a repullic, in a society at once so wide and so oll as onrs; and that, too, in spite of any number of "academic" repullicans amongst us. On the other hand, however, the mu societies of our Colonies will ccrtainly be republics, if, and when, they are to secele from their Mother. Whether, say a century or twe hence, under an mited Empire, the Colonies, in that probably predominant progress anticipated ly .Ir. W. H. Snith, may in turn sway the parent, as she for the present sways them, and thus make the whole Empire one grand republic, is, of course, a possible question, but hardly as ret, as one might say, "within the range of practical politics."

But, although any persons amongst us, few or many, may engage in Fecleral Assembly-making, without the is:k of eren the tiniest Thames tributary ruming with blood,-for it would be really only a variety of our constitutional form-yet I feel assured that, in this mode of the unifying, the step is too great ever to lue talien, and that we only waste precious time over its discussion.

There are, no doubt, other mocles of federation. For instance, Sir Henry Loch, Governor of Tictoria, had one of lis own; and the readiness with which he discussed it with me, although I hau called upon another matter, showed most encouragingly how 
much the subject was thought about, from top to bottom of colonial society. Substantially, his idea was that the Colonial Legislatures should appoint representative Imperial delegates. But, in the first place, this implies not only practical unanimity as to Empire unity, but also as to this particular plan of it; so that I must infer, on the preceding principles, that such a step outside the current line would never be taken. In the second place, the delegates' conclusions were to be referred for confirmation to the respective Colonial Parliaments, which might, or might not, agree to them. This latter contingency seems to me fatal to all right and complete idea of the political unity of the Empire.

\section{The Cabinet, pilus Colunial Representation, as the} Empire's Executive.

It has long seemed to me that the Cabinet is the convenient instrument which we hare, ready to hand, to play upon in this all-important question. This is not my own suggestion. It was first made, I think, some fifteen years ago, in the Royal Colonial Institute, by my relative, Mr. R. A. Macfie of Dreghorn Castle, Midlothian, when M.P. for the Leith Boroughs. It was afterwards, quite independently, I believe, adrocated by Sir Charles Tupper and others. But, curiously enough, these gentlemen went for limiting the Colonial element to Colonial questions. But, although this might be the beginning; it could hardly be the finality, in an equally represented Empire. 
Of course, we have constitutional forms to arrange ere fully emporwered Colonial Calinet Ministers could appear. Let me point out what might he done in thes mean time under the marvellously adaptive facilities of our constitutional system. What is to prevent the Queen, by advice of lier ministry, naming Colonial representatives, to sit, for the prescent, as an advisory body in the Cabinet? The nominations might he made under some guiding indications invited from the Colonies. Such a significant preparatory step would be practically equivalent to one half the accomplishment of the Empire's unity, and would certainly, I think, be followed ere long by the completing steps.

In conclusion, let us aim to hare no needless delays ; not only on behalf of the Empire's power, influence, and safety, but in order that we may have the better chance of completing so great a work within the lifetime of the Queen, and of giving so fitting a climax to so long and so glorious a reign.

\section{Postscript.}

On the priesent Columial relations, as a suppused basis for Irish Home Rule.

A few words on this sulject may clear up some tendency to confusion. In that Irish question, which now so seriously divides our country, some Home Rule adrocates have most crudely proposed to place Ireland on the present footing of the Colonies, as though the latter belongen to a regular system, 
as well as a system which was supposed to have worked acceptably and satisfactorily as between mother and offspring. But the fact is, that there is no mutuality of system whatever in the present colonial relations, nothing having arisen but the blindly hap-hazard that has come out of meeting of emergencies or wants, in hand-to-mouth fashion, just as they arose. Practically, our chief colonies, with the concession made to them by their mother, of their own respective constitutional governments, are now in a state of political separation, which, as we fear, must, however gradually, result, by quite natural tendencies, in the disintegration of the Empire.

The object of our Imperial Federation League movement is to change this anomalous and undermining position for one which, while reserving to the Colonies the charge of all their respective local concerns, gathers all questions of the Empire under one supreme executive, in which Home and Colonies are to be in proportionately equal political representation.

But, again, as to whether the new system now sought for regarding the Colonies might also suit Ireland, supposing Home Rule to be conceded to its more or less special circumstances, I prefer to avoid the expression of an opinion. 'That is a Ilome question, and this is a colonial book. I may, however, venture to point out how the proposed reformed colonial system would look as applied to Ireland. Ireland's connection, then, would resemble that of the Colonies as we propose to make it, if, 
with an approximative Parliament of her own in Dublin, she ceased to send her full qunta of memhers to the Imperial Parliament; but scint there instead a small selection, say about four, who were however, also to be in supreme Imperial Execntive position as members of the Calbinet. That is to say, in short, that when the Colonies are proportionately there also, Ireland will he duly represented along with them in the whole Empire's Executive.

\section{A Colonist's View of the Irish Question.}

Pursonally: I have been constrained, against will and abstract principle, into the Home Rule and "Gladstonian" ranks, on the ground that the first interest, safety, and duty to the Empire is to reconcile the Irish people. But, although now a Home resident, I am still colonist enough to retain, on Home Party questions, the tempered colonial sentiment, which can, without prejudice, appreciate at least the men of all sides. Indeed the experienced and large-minded head of the present Government is hardly less an object of my admiration and national pride, than the venerable and crowning statesman who happily still, and, vigorous as ever, heads my own proper party. I fear that the present course as to Ireland is a drift into an endless fighlit. England can, of course, with her greater power, repress Ireland; but, when the pressure ceases, the Home Rule want again crops up; and so Tantalus is secured in his unending work. Perhaps not the least grave fuct of the case, in the eyes of us colonists 
at least, is the general sympathy of the colonial Irish throughout the Empire with the Home Rule demand. This is happily as yet a hardly known power for disturbance; but the late incident as to the Queensland Governor may be regarded as not impossibly only the beginning of trouble, while at the same time it is not necessarily associated with disloyalty in the Colonies.

Ireland's case, alike past and present, is to me distinctly special. Home Rule is an Irish, not a general question. Which side is to blame for Ireland's ceaseless alienation is perhaps now a fruitless inquiry. But that the Irish, naturally joyous and generous, get on well with all the world's people except the English, is surely a significant part of the case. The Anti-Home Rule Government now in power are prone to urge that they are engaged simply in maintaining in Ireland the laws common to the whole country, while their opponents there are engaged in breaking them. That may be mainly conceded if we are to look only at one side. The Irish do not, any more than the common sense of other civilised society, oppose the benefits of law and order; they oppose the English local administration of them. It is really the Anti-Home Rule policy which is responsible for the law-breaking, as there is ever apt to be a ready crop of desperadoes where there is a long-continued political grievance. The question then, is, whether we are to go on for ever with Irish repression and Irish alienation, or concede the far less serious matter of Ilome Rule. Ireland gets steadily worse under the former course. What 
would have satisfied her under O'Connell will not do now; what may do now will be insufficient in another quarter or half century. The constitutional Parnells of to-day will then have been aggravated into Davitts, the Davitts into O'Donoran Rossas, and the utterly desperate be a further great step the nearer. Grant the Home Rule to-day, and the probability is that all this array of law-breaking, so far as connected with this question, ceases at once, and a new page in Ireland's temper is definitively turned.

When I speak of the tempered colonial sentiment as to the Home political parties, I prefer to go on to express my strong and pleasing expectation, that when the colonial element has been duly fused with the Home, in the future unity of the Empire, an altogether new era may begin to arise in Ilome Politics. Not only the sharp edge of to-day's party feeling may be rounded off, but an entirely new basis or direction be given to the party government of the future.

\section{ARTICLE IX.}

SUGGESTION OF A MONARCHIC-DEMOCRATIC PEERAGE OF THE EMPIRE.

TuIs question, which, in the progress of the Cnited Empire movement, with its effect of marshalling more prominently the natural democracy of colonies, might come shortly to be one of no small interest, occurred to me while lately in Australia. The occasion was in connection with the reyal grant of some 
specially distinctive honour to the two illustrious survivors of the Henty family, who represent to-lay the foundation of the great Colony of Victoria.* I do not know whether my friend Sir Robert Herbert, to whom, in writing on the sulject from the Colony, I gave the mere hint of my idea, has deemed it worth taking in any wise into his counsels. I will now, however, add a few remarks that occur to me on the details, in the hope that they may not be without interest to those of my readers who enjny such questions; and I will venture to add also, that they are all made in a spirit of entire loyalty to the venerable institutions of my country.

The question is as to how the old socio-political forms of our society are to live and work along with the inevitable modern democratic tendency. This tendency is being developed at Home, but it is more incisively prominent in the new societies of the Colonies. There is perlaps something eren grand in the idea of a sort of reconciling "peerage of the Empire," which will accord with the new democratic and not be at variance with the old monarchic ideal, and which might be conferred impartially, at IIome and Abroad, upon great personal merit or public service, particularly with reference to surpassing service on behalt of the many great interests bearing upon the Empire.

* Sinco the abore was written, my friend and most hospitable entertainer in Melbourne, Mr. Francis Henty, has "passed to the majority." Ile dichl, as the announcing telegram states, on 18. Fannary, 1889, the last survivor of a nolle brutherhood, who all contributed, more or less, towards fuunding Victoria. 
Outside of England, amongst the old subsisting monarchies of Europe, the progress of admitting, or submitting to, democracy has not been a fiast race. France, with her impulsive irregularity, is, however, an exception. Science in all its wide inclusiveness of to-day, and literature and commerce, which are the powers that now move the world, are as yet only very gradually struggling to the front. They are bent on at least a co-mastership) on its surface, so that those who turn the world round may be no longer dominated by those who are only turned round with it. Russia, where officialdom alone comes to the front, we put at the lower extreme, ourselves at the upper end, and struggling Germany somewhere between. But Germany's march has not been a gallop, if, at least, we may judge from an exquisite story of German travel which I read some years ago. The author was evidently one amongst lis country's legion of officialdom, and if not very high in that, or indeed, as we might infer, in much else, he had yet evidently a most competent idea of his own class. He tells that, passing through one of the German towns forty years ago, he witnessed a most imposing funeral cortège. Enquiring who it was who was thus honoured, he was told, as he naïrely states, that it was a person of the name of Goethe, and that as much fuss was made over this man as if he had been a major in the army.

Well, after all these various preliminary remarks, we come at last to the exact point, namely, what, in all the various circumstances of our Empiremonarchic at Home, and strongly democratic, even 
republican in natural tendency in the Coloniesshould be the suitable constitution of a new, a pro re nata, Empire peerage?

First, of course, and as principle of principles, it should be a life and not a hereditary honour; one of a person, and not of a family. The high honour should be attainable only for high personal qualities or services.

Second, "My Lord" has too often been a difficulty with the work-a-day world of science and business, little as it may be deemed or felt so by those "who are to the manner born;" and accordingly one of the questions or difficulties of the case is some democratic compromise with My Lord.

Old France had a delicacy of adroitness in this sort of thing, which was only one of her many superiorities in point of the manner. "Monsieur" was the title common at once to the heir to the throne and the heir to the charwoman and the rag-picker. The ponderous "Monseigneur" was left fitly to the high clergy. The small, hardly visible particle "de" signified nobility. If our less expert ways in such delicate matters have at times exposed "Milord Anglais" to some claff from the lively humour across the Channel, the Empire Peer, besides other advantages, may hope to escape even this small ordeal.

But, as compromise is the order in iny present case, there must be fair give and take. "The Democratic" having escaped from "My Lord" in its ordinary or work-a-day life, must in turn be conresling, if from no ligher than considerations of 
gratitude. All should be oflicially " My Lorl" within Parliament, much as the linther of the Lower Honse is ". The Honourable Member " upon his own floor.

But, is a lesson to us from the French methoul still impossible? Let us look at both old Scotland and old Ireland, where "the" may stand for the French "de," and where we have still those most true and ancient nolles, "The " Macintosh, " The" Chisholm, "The" O'Donoghne, and many other heals of the old clans. Here is an opening for democratic ingenuity in compromises. Heredity is, no doult, still a part of this Highland and Irish case, but that part may be dropped out.

3rd. But the Empire Peerage, in any case as to the matter or manner of title, must have full peerage rank. It must not he inferior to mere Unitel Kingdom peerages, the Royal Family, of conrsc, excepted. At the same time it is not fitting that our grand national traditions should be affronted by the senior institution, although the narrower of the two, being duminated by the junior. And, again, those of the ancient but narrower rank may always, if so minded, aspire to the broader through the common gateway of "the merits."

4th. But where the peer, under this great prospective extension of his order, is to cunnt ly thousands instead of the present hundreds, the crowling case must needs involve other changes. This need for linitation brings in the principle of election. The future Upper House of Legislation will have to be elected, in suitable number, out of the whole 
peerage, and this the incapable and the untrorthy, who were fixtures under heredity, may be dropped out. Aud, again, those Right Reverend Peers, whose National Church political exigency already threatens, may add materially to the length of its life, besides, perhaps, securing permanently, if they value such mere temporal thing:, their om peerage rank, in the new system, by being dropped out of the more invidious legislative category. And lastly, as this expanding upper suciety must contemplate "pecresses in their own right," as well as peers, and perhaps also in no small numerical proportion, there is a rare opportunity for certain steps in woman's rights, which are now increasingly associated with a true socio-political advance. The ner London government has alrearly indicated a leaning in that direction. A peerage thus reconstituted may show that the old immobility in that ligh quarter is now not only done with, but possilly converted into a successful rivalry of progress.

Turning here to a side issue which may not be without interest, our American cousins, let me say, when they slid away from us, might well have compromised for some such form of purely democratic nobility as this Empire Peerage, in substitution for the monarchical which naturally fell from them. Their earliest and greatest citizen, ly inaugurating "The Trashington," would have been more specially or personally titled than as an indiscriminate "Lord" Washington. And thus a kind of grand national Upper IIouse, ever leing selected out of the most approved of the whole people, and accessible 
as to membership, like their presilency, to every. citizen "on the merits," might have leen estahlisherl with all the steadying adrantare of presuting al ways. and in every direction, a solid fiont of recognised superiority. Indeed, has not something of that ameliorative lind leen wanting to the Gruat Republic, whose nliquitous democratic llains have hardly been varied, in socio-scenic effect, cxcupting by mountains of dollars?

The Emprire Peerage must of, course. lie largely Colonial, sceing it forms the Colonies first chance in that way, as no peerage has, I think. been yet granted in a strictly Colonial direction. althongh knighthoods are already superabundant, and baronetcies later on have had a fair begiming. Int the Colonies are not to be, ly any means, exclusircly masters in this new field, seeing there are at Home many heads of the moving powers of the world whin are still excluded from the Peerage, widely openal as, in a comparative sense, that has been of late. Perhaps the nost remarkable exclusion of all has been that of men of science. Darwin and Ower. 'Tindall, Huxley, and Thompson should all liave been, eren long' ago, in the House of Lords, if omr Upper House is to have any connection with the highest human attaimments, and with pursuits in the very grandest sections of practical and general science. Some years ago, while enjoying a great dimner at our hospitable Mansion Honse, and looking around, in the spirit of one who seeks concernedly to implement the Scripture as to "who is my neighitour." my eyes lighted upon the well-known and now arged form 
of Professor Owen. He was seated amongst the common crowd, not far from myself, and in a position which, in the jumble of accidents and head-counting of that section of the company, might have been hardly so good as my own. Had I been Lord Mayor at the time, I should certainly have at least tried to place the renerable Prince of Science next to the Prince of Wales, whose most genial presence happily graced the occasion.

In conclusion, there can be no doubt that an Empire Peerage, of the democratic kind proposed, with its marked effect of mixing or tempering the old with the new, does somewhat dim the glitter of traditional aristocracy, and deprive it of much of its long-accustomed objectireness in the society. But indeed, in these practical and common-sense times, the truth is that most of even our hereditary upper class have preferred already to descend to the terra firma of ordinary life and work, rather than to unconcernedly vegetate in the clouds orerhead. Thus a Salisbury and a Granville, a Carnarvon and a Rosebery, splash the common mud as vigorously as if in their native element, or as if, in a nerw and an entirely reversed sense of an old phrase already quoted, they were altogether "to the manner born." This equalising tendency, in short, seems precisely the want of the case. To attain that result must mean success, for our Empire is no longer simply monarelical, but, in the term that heads this Article, monarchic-democratic. 


\section{AR'TICLE $X$.}

TIIE MOUNT MORGAN GOLD MIXE.

I IIAD not intended to notice particularly the Mount Morgan Gold Mine, as I had not, while lately in Queensland, any information to the effect of its differing from other gold mines, further than being of an unusually rich character. But the description given to me of it by my frieml and Home fullow passenger, Mr. John Wagner, who is one of the earliest, and who still continnes one of the largest shareholders, so aroused my interest, that I have since been on the outlook for all the guiding data as yet to be had, in order to present my readers with some reliable account of a most remarkalle natural phenomenon. Mount Morgan seems to be an entirely unique instance of its kind, alike as to the character of the mineral furmation and the unprecelented quality and richness of the auriferons matrix. As the mining on the Mount hitherto has hardly more than dealt with one mere corner, the world's market has as yet felt no evidence of what really awaits it in this hill of gold. And such is in fact my chief reason or excuse for this Article X.

Scientific observation and de.luction are, of course. invaluable, to compare with the views of practical miners. Accordingly I bave been waiting, but am sorry to say as yet in vain, for the pullished report of the examination of the mine made in the middle of last rear. 18s8. lyy Mr. Wilkinson. the Govern- 
ment geologist of New South Wales. Wanting that, I had still two scientific descriptions to help me, as far back, however, as 1884, namely that of Dr. Leiljus, in his "Notes on Gold" (Sydney Morning Iterald, 3rd July, 1884), and the official report of the Queensland Gorernment geologist, Mr. Robert L. Jack, who gives the further help of a map of the district. I have also derived much information froin a series of four articles of the Rockihampton Daily Northem Argus, of dates 17th, 19th, 21st, and 26th January, 1887, the author of which is evidently well informed in practical gold-mining. With these I had to compare the information given me by Mr. Wagner, and his friend and copartner Mr. Walter Hall, to whom he introduced me in London since my return. I propose, then, to give briefly here, first, a history and description of the Nount; second, an estimate of its gold contents; third, some guessing as to how it was produced; and, fourth, some estimate of the effect upon the world's market.

\section{History and Description of the Mount.}

The first persons to gire attention to the Mount were three brothers called Morgan (whose name was afterwards given to it), who in the year 1882 were engaged in gold or other prospecting thereabout. They noticed the remarkable-lonking stone of the hill, and not to lose any chance, although no gold was visilhe, they sent a sample to Sydney for analysis. 
The result was so extraorlinary as to richness, that fearing some mistake, they sent a second sample, but only with the like result. They then took measures to secure their prize, assisted by the money of some Rockhampton residents who shared in the enterprise. Half the Ifount was at this time included in the square mile, ọ 640 acre section, belonging to a landselector called Gordon, who was promptly bought out at $10 s$. per acre, and who, under such an unaccustomed load of money, betook himself to the public-house, where he soon laid down both his life and his means. Next, the other half of the Mount was secured by mining lease of 21 years from the Gorernment upon comparatively nominal terms. Mount Morgan fame was now established, and above a year afterwards the Morgans, four in number, including a son of one of the brothers, sold ont their whole interest, realising about $£ 100,000$. One of them has since reappeared in Wales, with further honours in successful gold prospecting. Mr. Walter Hall, Mr. John Wagner, his partner Mr. Robertson, and some few others had by this time acquired the whole property. Three years ago they formed it into a company of $1,000,060$ shares, each of $£ 1$, with 17s. 6d. paid up. Of this stock these original owners still held the largest portion, only about 300,000 shares having passed to the pul,lic in order to provide funds to work the mine.

Mount Morgan is situated 26 miles south and slightly west of Rockhampton, the capital of Central Queensland. It is about 500 feet in height above the surrounding plain, while the plain is al out 700 
feet above sea level. The upper two-thirds of the hill are by far the richest in gold. Two tunnels driven at different levels into this part, one of 200 feet, the other of 500 feet in length, have disclosed matrixes in no small quantity, rising to the unprecedented richness of 700 to 900 ounces to the ton. The lower flanks of the lill are much poorer, and in some directions have scarcely any gold. The notolious Mount Morgan West boundary, on the lower western flank, comes within a furlong of this rich material, and yet, neither at that place nor further off to the westward, has it as yet yielded any dividend to its owners.

\section{Estimate of the Gold of Mount Morgan.}

Mr. Jack, in his geological map of the hill and surroundings, gives the shape of the richer upper section as that of an egg, whose longer diameter was rather more than a quarter of a mile, the shorter section leing rather less. Thie flanks he describes as comparatively poor, being the overflow of the hot spring or geyser, to which he supposes the auriferous liill to be due; but, beyond remarking that there is both very much and very rich auriferous material, he makes no estimate whatever that might guide us to the total. Neither does the Argus writer to whom I have alluded. IIe mentions that much of the stone has areraged 5 ounces to the ton, and some sections of it as much as 130 ounces. But, from what Mr. Hall and Mr. Wagner have told me, the two years which 
have elinsed since the remarks of the Aryus writer have shown it to be almost incredibly richer than was then supposed. The estimate now made is that the whole hill may average $T$ ounces to the ton. The hill and its flanks may average two-thirds of a mile in diameter. In shape the hill has an ordinary rounded peak appearance. The stone is sufficiently compact to be taken at one ton weight per culjic yard. And thus we reach a rough estimate of perhaps quite three hundred millions of gold, supposing the still unexplored interior to correspond to what has been exposed.

And now we come to ask what has been doing all this time with all this gold? When I repeatedly asked my friend Mr. Wagner to explain this, his unvarying reply was to the effect that, however remiss in the past, the company were now all alive to the future, and are preparing the necessary means. Hitherto Mount Morgan has yielded to the goldfamished world only from half a million to a million and a half of gold yearly. But this year the machinery has been so perfected, that it is to yield a little over three millions. This, however, is from work in one section only, while all the rest of the hill is in abeyance.

One cause of this inadequate procedure has been the very unusual, or rather the unique, character of the auriferous matrix. All gold found hitherto, however minutely distributed, has been, as I understand, in simple mechanical combination with the matrix, which is generally a form of quartz. It has thus only to be reduced to powder, and, by running 
quicksilver through the mass, all the disengaged gold is picked up in the amalgam. But in this case the gold has been to a large extent in a state of chemical combination, and thus, with this portion, a chemical process called chlorination has to be used. But chlorination is a most explosive process, so that, when the richer stone is dealt with, the strong barrels which are made use of are apt to be blown to pieces. The richer stone, therefore, can be only very gradually realised by being mixed with the poorer. A concise and remarkably clear account of Mount Morgan, and of this chlorination process in particular, is given by the late Lady Brassey, and with the usual life of her style, in "The Last Voyage of the Sunbeam," 1887.

Mr. Wagner mentioned that the owners of a small vessel had on one occasion bought from the company a loading of some of the richer stone, and taken it, as was supposed, to Germany, the vessel being German, where it was reported to have realised such an enormous profit that, viewing themselves as practically cheated, they avoided further dealings in that way. I asked him how this incident did not suggest to the company to ship this richer stone on their own account. There were IIouses in London which might be trusted to account faitlfully for every penny of proceeds. My impression from his reply was that this course might be considered along with others. It would, of course, lead to a much prompter realisation of the gold. 


\section{How the Mount was produced.}

Both Mr. Jack and Dr. Leibins agree in attributing this auriferous deposit to thermal spring operation. Mr. Jack in particular is clear upron the geyser-like aspect of the case, the mineralogrical features of the deposit having generally the appearance of such origin. The Aryus writer, on the other hand, totally denies this conclusion, although he admits that some parts of the surface may have the appearance contended for. Ile thinks that strong magnetic or electric currents lave brought up the gold, and that in the direction of these currents we may still find more of such rich deposits not far off?. He thinks too that much of the quartz matrix has the appearance of igneous origin.

I had just concluded this article when I happily received from the Colony the Bristune Courier of 10th January, with the second report of Mr. Jack upon the mine, based on observations mate so lately as Norember last (1888), at the instance of the Queensland Govermment. By this time the liill liad been tunnelled at rarious levels, and to great interior distances, with a total driving of ahove 7000 feet, so that there was now the means of very enlarged examination. Mr. Jack, however, still adheres to his first idea. "The eridence now in hand, in my opinion," he says, "goes to confirm my original view, that the auriferous material was depositel by a thermal spring." He quotes the quite contrary opinion of Mr. J. Macdonald Cameron, member of 
the Legislature, and a local geologist, who reporterl upon the mine to the directors in March 1887. "I certainly differ from Mr. Jack," he says, "as to the nature of the method of formation." The further exposure of the interior of the mount has shewn a great varicty of matrix character, from the prevalent ferruginous quartz, usually rich in gold, to "silicious sinter" and other mineral forms, much of which is rery poor, and in some instances without any gold. The other view as to the origin of the gold traced it to a great bed of iron pyrites, mingled with quartz, the decomposition of the pyrites having supplied the gold. Further peculiarities of the Mount Morgan gold were its freedom from the combination of silver, and its remarkable purity in other respects-to the unprecedented extent, indeed, of 99.98 per cent. with a value at the Sydney Wint of $84 s$. $8 d$. per ounce. I must also add that a more critical observation of late has found some partial resemblances between the Mount Morgan circumstances and those of some other Queensland gold mines. I still adhere to Messrs. Hall and Wagner's estimate of the hill, because they had both just returned from the place, and were thus the latest authorities.

Evidently "doctors differ" here as elsewhere. Science has as yet very little explained the gold indications, and Murchison's chief "constants" have proved, at least in Australia, the most inconstant of thing's. Two difficulties, besides the disputed mineralogical indications, seem in the way of the thermal springs origin. 1st. Snch a miss of gold 
from the comparatively moderate depth of any spring or geyser is altogether muprecedented and milikcly. We must suppose that the spring or springs traversed auriferous regions beneath, of which what was brought up was the merest fraction. 2nd. 'The spring theory hardly accounts for the chemically. combined state of so much of the gold. This seems to point to a much higher temperature than any that is likely to be associated with geysers, even under the strongest subterranean pressure.

'T'wo of Murchison's principles may help us in this difficulty. He remarks, first, that gold is never fomm unless with subterranean upheaval. Thus all the flat country of European Russia is without a particle of gold, till we reach what is geologically the same country upheaved in the Ural, and there is the gold. Next he lays down that the gold is found only where the upheaval has a general north and south direction, and not where it is easterly and westerly.

If we could suppose that at the subsiding of the earth's crust the heavy and refractory elements such as gold fell into the lower positions, it might be that gold was no scarcer than many other things, if we only succeeded in penetrating low enough to reach it. Mount Morgan may have come of an exceedingly lot jet set in upward movement from an unusual depth-a comparatively small neck, which cracked and melted, rather than upheaved, in its upward course, and on reaching the surface emptied its rent into the present Mount Morgan. We might go on to suppose, of gold indications generally, that the north and south directions of upheaval were helped in 
intensity and depth by magnetic or electric forces, while the other directions of upheaval, which were without such help and such depth, failed to touch the gold.

\section{Effect upon the World's Market.}

If this calculation as to Mount Morgan gold be substantially confirmed, and if it begin to be turned out upon the world's market ere very long with that greater promptitude which seems to me inevitable, the amount and the pace of supply will form together an unprecedented instance in the life and history of the precious metals. Australia and California unitedly, nearly forty year's ago, increased, almost suddenly, the yearly gold supply from eight millions to thirty millions. This total supply gradually decreased, during thirty-five successive subsequent years, to a minimum of eighteen millions, from which, lowever, it has now recovered to twenty-two millions, with the prospect for this year, 1889, of being perhaps quite twenty-six millions, in view of the South African and the definitely ascertained Mount Morgan increase.

When we add, by way of crowning these vast figures, the estimated capitalised proceeds of Momnt Morgan, we would seem on the verge of unprecedented, nay, incredible, revolution. But there are two circumstances which, working concurrently, will probably enable us to sweep through all this pruspective ordeal with at once such facility and such quietness as hardly to create even the consciousuess, 
amongst any of our countless pecuniary interests, that anything very unusual is affecting them. These are, first, the enormous additions that began, some years later on than the gold, to be made to the supply of silver, and which continue unabated until now, the yearly supply having risen from about six millions to twenty-six millions; and, second, the vast scale upon which gold and silver are now dealt with in the world, one of the items of the stock-of course the chief item-being the collective coinages of all the commercial states, estimated now to be but little short of two thousand millions, anul probably divided very conveniently into almost equal proportions of each metal.

Mr. Goschen, three years ago, indicated clearly an "appreciation" of gold, which had been going on steadily for some ten years before, not merely from the above stated decreasing supply, but from a common scare in some chief states, inducing them to increase their gold and diminish their silver coinage. Dr. Giffen has at last reached the same view. He finds that gold, while not increasing in production, is yet very largely increasing in use in the world, and he predicts that ere long a pound may be a seriously heavier obligation than it is now. Our Colonies for instance, he says, which run merrily into scores and even hundreds of millions of debt to-day, may have more than they bargained for to reckon with to-morrow.

Our London bankers and capitalists made no objection whaterer to this increased exchange power of the pound which told so well for them. They 
were more than ever gold monometallists. The appreciation might indeed oppress the debtor whereever gold was the standard; but, as England was everywhere creditor, her gain was thought to be indisputable. But, now that Mount Morgan threatens not only to arrest gold appreciation, but to cause even some extent of depreciation, the philosophical indifference of the said bankers may be serionsly shaken. Do they like the pure alternative that gold, as silver did when bimetallic action was suspended, should "come down like a shot," or would they not prefer that, as the late M. Chevalier would have put it, that the gold should come down like a shot attached to a parachute? That is how the bimetallic action would result, in associating the two precious metals so as to work practically as one standard by means of a fixed ratio of value. The timely gold supplies of Mount Morgan, coming so shortly after the favourable view of bimetallism from the late Monetary Commission, may possibly lead to the prompt restoration of bimetallic action under the old and convenient ratio of $15 \frac{1}{2}$ to 1 , to the unbounded relief and satisfaction of a large section of our own and of the world's commerce. 


\section{A P P E N D X.}

Trie following extracts are from the letter of an whl M[e]boume friend, who, unatile from ill-health to call upun me, had written his letter in consequence of some remarks I harl made in a public speech. I have deemed it best to suppress all names, as my olject is solely to illustrate priuciples.

"Yesterlay I saw you had a farewell with the memlers of the Chamber of Commerce, of which I was a menberI think from your founding it-for many ? ears. Iint I am not a member now, as I have been engaged, as you may know, in mining. It was your specch on this branch of our Colonial industries which attracted my attention, and especially those remarks in reference to the flutation of mines by London promoters, and the outracreous 'loading' for commissions, fe., \&e., which so terribly handicap such ventures.

"Some years agro I wrote to you about my haring sent such mines to London, especislly the . . . . This mine was cruelly overloaded, and so failed. Since then it has paid orer $£ 30,000$ (I speak from memory) in dividends, and is as likely to pay for years and years, as when I haul it under offer. I slaall indeed be glad if you "an instil a little more fair dealing into the promoters. It is a firr.t that where I sent properties 'Home' at a ra-h valuation of $£ 130,000$, the promoters wanted to get $\AA^{\prime}+00,(11)(0)$ !

"I never thought you would take any interest in mining, as you treated my approach to you on the sulject with so distinct a negative. If I lad known in time I imagine I could have given some good facts; and it in the future I can assist you in the good work, pray command me."

The other case was a somewhat dilfi rent pliate of extortion. But I might, as to it, repeat ny friend's words abne quoted: "this mine was eruelly overlinuled, aul so faileci." Even these promoters would be benetiter if their overluad- 
ing should be abolished, berause then their schemes would have better chance of life.

An old Culonial friend of mine, who was chairman of two small New Zealand gold mines, opened negotiations some few years ago with I.ondon for raising $£ 25,000$ upon each, in order to increave the water supply, by which they could very greatly increase their gold product. The money was to be raised by preference shares at 12 per cent. dividend, and the buyers of these shares, chiefly or wholly, I think, the London ordinary shareholkers themselves, were ready with their payments. At the last stage, a commission of 12 per cent. was put in as a sine quâ non; and this so exaspesated my frieud, as a charge that seemed to him alike unconsciumable and disreputable, that he at once broke off the transaction, so the promoter got nothing at all for his trouble, while $\mathrm{my}$ filend's mines are just where they were instead of yielding to a good many investors, on very fair security, a most comfortable return for their money. 


\section{N D E X.}

Australian 'Transcontinental Railwry, 281-286; Chinese and, 281-286; Act, $38 t$; Preface, vii, 338

A

A'Beckett, Mr. 'T'. 'I', 76

Adelaide, 43, 272, 276-280; Government House, 278; wine-making, 279 ; interviewing at, 292

Aden, 313-320; various races at, $318-20$

Ak̉aba Gulf, 322

Akaroa, 193, 194

Aitken, the late MIr. J., 241

Albany, 298

Albi, Mons., 110

Albury (N. S. Wales), 87, 91, 93, $: 74$

Arrow River, 219

Arthur Seat, 37

Atkinson, Sir H., 117, 15i-160, 204

Atkinson, Messrs., 167

Auckland, 151 ; climate, \&c.; 152156 ; Cairn's Hotel, 152

Australasian Astociation for the Promotion of Science, 105

Anstralasian Federal Council, 1889, x; Colonial Group, 13; frozen meat trade of, $3 \pm 1-350$; 'I'arift' difficulty, 373

Australasian Dominion stock, 27, 28

Australian climate (and drought), Prefice, v, 3 $11-341$

Australian Mortgage Land and Finance C'o., 105
B

Ballarat, 243, 245, 253-255; golu mine, 255-257; Town Hall, 258

Bank of New Zealand, 153, 161, 191, 208

Banks' Strait, 229; Peninsula, 193

Barker, Mr. J., 58

Bass's Strait, 36, 229

Batman, John, 44; Batman's Hill, $47,78,144,251$

Bay of Islands, 151

Beit, Mr. John, 161

Benjamin, Alderman, 58, 63, 72, 73; Mrs., 331

Ben Lomond ('l'asmania), 3t, 229

Ben Nevis (Mt.) and depth of Red Sea, 322

Bergh, Rev. MIr. (R. C.), 152

Bird, Mr. (Tasmanian 'I'reasurer), 25,228

Bischoff (Mount) and tin, 30

Black, Dr., 76

Blackley, Canon, 250

Black, Mr. R. I., 105

Blaine, Mr., 380

Blaxland, MIr., 147

Blue Mountains, 124, 143-148

Blue Gum Tree of Australia, 155, 203, 231 
Blyth, Sir Arthur, 279, 280

Channel Tunnel, 249, 250

Bonwick, Mr. Jas., Preface, xxii, xxiii

Boothby, MIr. (Sec. C. of C.), 295

Botany Bay, 99

Boulanger, Genl., 311

Brassey (late Lady) and Mount Morgan, 406

Breakfast Creek, 135

Bride, Dr., 69

Brigham, President, 8

Brisbane, 124; Custom House, 130 ; streets and buildings, 132 ; bank:, 132 ; waterworks, 135 ; river, 129

British Association, 10, 55, 339 ; at Montreal, 12, 380

British India Steam Co., 5

Broad, Judge, 166, 191

Brodie, Mr. G. S., 252

Broken Hill Silver Mine, 62

Brown, Mr., 172

Burns, Hon. Mr., 101

Butterworth, Mr. (of Ohio), 381

\section{C}

('airnes, Professor, 330

Cairns, Mr. A., 79; Rev. Mrr., 255, 258

Cameron, MIr. J. McD., $40 \overrightarrow{7}$

Camphell, Hon. Alex., 94

Canadian 13oard of Trade, 357-359; Pacific Railway, 5, 26; Dominion, 25, 205, 366, 381 ; stock, 26

Canarla, Federation of, 26

Canary Islands, 15, 16

Cape Leeuwin, 299, 301, 36 \&

Cape 'Luwn, 16, 17

Carr, late Captain S., 85

Carrington, Lord and Lady, 102

Cassell, Mr. and Mrs., 74; Hon. J. II. Nelson, 74

Ceylon and Coolies, 303, 304; fentures, schools, isc., 310,311

Chapman, Mr. Fred. Revans (son of Judge Chapman), 191, 222

Chartered Bank of Australia, Brisbane, 132

Chevalier, M., 412

Childers, Mr., 29

Chinese and Australian Transcontinental Railway, 284-286

Christchurch, 154; schuols, 190; and water supply, \&c., 195-198; earthquake, 198-:00; frozen meat trade, 346

Christie, Mr. Wm. R., 246

Chubb, Mr., Sen., 138

Churchill, Lord and Lady Arthur, 14,21

City of Glasgow Bank failure, 211

Clarke, Sir Wm. J., Bart., 238, 239

Clarke's Island, 229

Clutha River, 217

Colac, 144

Colombo Harbour, 312

Colonial Bank of New Zealand, 208, 209

Colonial Exhibition, London, 41, 175

Colonial loan issues, 22; finance, 22 ; interests and London markets, 265-270 ; government, 362

Commercial Banking Co. of Sydney, 105

Comorin, Cape, 313

Conlan, Captain, 296, 297, 331

Consols, 23

Cooke, Mr. J., 197

Cook, 'Thos., \& Son, 331

Cook's Strait, 15 1 ; squall in, 157, 165,186

Coppin, Hon. George, 66

"Coptic" s.s., 5, 14, 19, 152

Cowderoy (Mr.), Secretary Mulbourne C. of C., 39, 231, 232

Curr, late Mr. Edward, 74

Curtis Island, 229 
Fell, Mr. Charles 'l', 166

Fergus, Hon. Mr., 191, 192, 218, 249

Fernshaw, 232-231

Fern-'I'ree Gully, 20

F'itzgibbon, Mr., 58, 72, 77, 383

Fitzherbert, Sir Wm., 162, 17t-17!

lilagstafi Hill, 47

Foster, Mr., 365, 367

Foveau Strait, 217

Fox, Sir William, 191

French Government and New Caledonia, 356

Froude (Mr.) and the Mormons, 7, 8

Furneaux Group, 229

Fysh, Mr. ('l'asmanian Premier), 21, $22,31,34,87,228$

\section{(i)}

Gambetta, MIonsieur, 249

Garrick, Sir Jas, and 'Tarifl' question, 371

Gear Company in Petoné, 179-181, 346

Geelong-football, $35,36,45,243-$ 246; Mack's Hotel, 245, 251-253; cured meat trade, 344

E

Germany and New Guinea, 35̃; and Samoa, 354, 355

Elder, Mr. A. L., 268, 276; Sir Thos., 271, 276, 282

Ellery, Mr., 259-264

" Empire Peerage," 393-400

Esk River (Tasmania), 34

Etna, Mount, 329

Gibbs, Bright, \& Co., 296

Gibraltar, 15, 16

Giffen, Dr., 411

Gill, Mr. Jas., 74

Gillies, Mr., $10 t$

Gipp's Land (north), 233, 237; Alps, 274

Glen Osmond Fills, 275, 276

Godeffroy's ships, 85

Gordon and Gotch (Messrs.), 49; Australian Hand book, 354

Fallon, Mr., 92

Fawkner, late Mr. J. P., 44

Federal Colonial Government, 363 ; Council Bills, 371 Goschen, Mrr., and 3 per cents., 23; and $2 \frac{1}{2}$ per cents., 29; Preface, iii ; and gold, 411 
Goulbourn, 93 ; Upper Rirer, 232

Govet's Leap, 145

Grampian Mountains, 89

Great Australian Bight, 298

Grey, Sir Geo., 151

Griffith Party, The, 367

Hadji-Baba, of Ispahan, 48

Half Moon Bay, 218

Hall, Mr. Walter, 402, 403

Hamilton, Sir Robert and Lady, 21

Hamilton (Canada), 160

Hauraki Gulf, 151, 154

Hawkesbury River, $1+1$

Healesville, 232, 233

Heaton, Mr. H., MI.P., Preface, vi

Hector, Sir Jas., 163

Henty, Mr. Francis and the Henty

Family, 41-46, 58, 89, 190, 251, 394

Herbert, Sir Rt., 391

Hobart, Lord, 43

Hobart (Tasmania), 5, 16, 19; Government House, 21; jams of, 35 ; Harbour, 228

Hobson, Dr. E. C., 74

Hobson's Bay, 37, 38, 79, 80

Hope, Dr., 180

Hopkins, Henry (of Hobart), 19

Hotham, Governor, 14

"Humbug Reach," 38

IInon River Road, 20

\section{I}

Imperial Government, 363,370 ; Federation, 377, 382; League, 379,390

Indented Head, 37, 45, 251

Inglis, Mr. Peter, 253

Inter-Colunial Federation, Prefice, xix, 25, 361, 365, 370, 382

Invercargill, 215, 216

Ipswich (Queensland), 133, 138

Irish Home Rule, 389; a colonist's view, 391-393

Irving, Mr. Henry, 333

Ismay, Imrie, \& Co., 340

\section{J}

Jack, Mr. R. L., 402, 404, 407

Jackson, Mr. Jas., of 'l'oorák, 74

Jarra Tree, 299

Johnson, Mr., of Manchester, 55

Johnston, Mr. Jas. S , 75, 76

Juhnston, Mr. Reverdy, 380

Joseph, Mr. S. A., 104, 105

K

"Kanaka" or coloured servant, 289292 ; labour, 363

Kangaroo Island, 43

Katoomba, 144-148

Kauri Timber Co. (Limited), 155

Kawan Island, 151

Kaye, Mrs., 241

Kemble, MIrs. H., 333

Kerguelen Islands, 18

Kilmore, 89

King George's Sound, 298

Knutsford, Lord, 175, 287, 364, 369

Koroit Creck, 243

\section{L}

Labertouche, $\mathrm{Mrr}$., 87

L'Agulhas Bank, 17

Laguna, 16

Lal Lal Station, 253

Lancefield, 240, 242, 251 
Langhornes, the, 74

La 'Trobe, Mr., 70, 71, 78

Launceston, $34,35,42,43$

Lawson, 147

Leckie, Mr., 157, 158

Lee, Bishop (Mormon), 9

Leibius, Dr., 402, 407

Le Souef, Mrr., 69

Lesseps, M. de, 324, 326, 327, 337, 338

"Leura" s.s., 124

Lilydale, 231-233

Lindsay, Mr., 238, 240

Lipari, 329

Little, Mr. (J. P.), 241

Little River Creek, 243, 244

Lloyd, Hon. Geo. Alf., 94, 98

Loch, Sir Henry, on Federation, 387

Longburn, 182

Lorimer, Hon. Sir Jas., 65, 82

Lyttelton Town and Harbour, 193195

\section{M}

McArthur, Mr. David C., 75

McCrae, Mr., 107, 113-123, 255, 258

McDonald, Mr. (Mayor of Ballarat), 257

McEwan \& Co. (Limited), 54

Macetown, 219

Macfie, Mr. R.A., 388

McHardie, Mr. Alexander, 3 6-3 49

MIllwraith, Sir T'homas (Queensland Premier), 27, 58, 88, 106, 122, 138, 287, '288, 352; party, 367,378

Mackenzie, Mr., 209

Mackinlay, 343

Mackinnon, Mr. L. C. ('Melbourne Argus $^{\text {') }}, 39,46$

Maitland, 140

Mallee Scrub, 273

Manawatu and Wellington Railway, 181-187, 206
Manley Beach, 143; town, 148

Manning, Sir Wm., $9 t$

Manukau Harbour, 15 $\$$, 157

Maori language, 177 ; chiefs, 185

Marsden, Mr. J. A., 76

Mate, Mr. Mayor, 92

Max Müller, Professor, 9, 176

May, Mr. and Mrs., 330, 331

Melbourne Centennial Exhibition, 2, $21,32,56,57-63$

Melbourne, winter at, 20; (Port), 37; Harbour Scheme, 38; wharf, 38, 251 ; Scott's Hotel, 39, 229 ; Menzies', 39 ; suburbs, 45 ; founding of, 45, 46 ; 'Argus' oflice, 46 ; Patent Office, 47 ; tramway system, 47; postage rate, 49 ; Press (the 'Argus,' the 'Age,' the 'l'elegraph'), 51, 52, 75, 92; 'I'rade, 53-56; Collins Street, 61, 82; Fitzroy Gardens, 65; Government offices, 65; Parliament House, 65; Grand Hotel, 65; Temperance Coffee Palace, 65 ; Opera House, 66; The Benevolent Asylum, 66; Victoria Parade, 66; Public Library, 69; Botanical Gardens, 69 ; Zoological Gardens, 69; Old Colonists' Home, 69; Dinner, 190; Hospital, 69; University and Royal Mint, 70; new bridge over the Yarra, 70; other bridges, 70; Town Hall and Clerk, 72 ; the Mayor, 72 ; Cemeteries, 73 76 ; suburban municipality, 76-78, 231 ; Harbour, 79-82 ; improvements; 82 ; comparison with Sydney, 95-98; Emerald Hill, 100 ; sewerage, 100; chimney smoke, 118; Bell bird in, 135; Observatory, 259-261; last day in, 265270 ; mines, 267 ; farewell to, 271 , 272 ; British Association, 339; hot winds, $343,3 \pm 1$; frozen meat trade, 345 . 
Merri Creek, 45, 76

Messageries Maritimes, 4

Michie, Sir Archibald, 76, 383

Mill on "Protection," 111, 120

Mining Speculations, 267-269

Mitchell, Sir Thomas, 89, 242

Monetary Commission, 412

Moore, Mr. David, 76

Moreton Bay and Islands, 129, 133, 136

Morgan Brothers, 402

Mormonism, 5-10

Morris, Mr. Augustus, 94, 143

Mort, Hon. Henry, 101

Mount Aitken, 241

Mount Cook, painting of, 62, 157

Mount Coot-tha, 133

Mount Eden, 153, 154

Mount Egmont, 154, 157, 187

Mount Eliza, 37

Mount Lofty, 275

Mount Macedon, 242

Mount Martha, 37

Mountain Meadow Massacre, 9

Mount Morgan Gold Mine, 61, 131, $135,137,139,267,338,401-412$ Mount Wellington (near Hobart), 17,20

Mouritz, Mr., 76, 82

Mud Islands, 248

Mullens, Mr. Josiah, 105

Murchison, 408

Murphy, Sir Francis, 76

Murray, Mr., 255, 257

Murray River, 91, 242, 273-275

\section{N}

Nairne, 275

Namoi Creek, 342, 343

Nankevill, 'I'. J., 76

Naples, 329

"Native Associations," 383

Neild, Mr. Cash, M.P', 150
Nelson, 154, 161-167; mayor of, 166 ; potatoes, 252

Newcastle Labour Strike, 125-129; paper, 140

New Guinea, 351-356; eastern, 379 New Norfolk, 228

New Plymouth, 154, 157, 158; Harbour, 158-160, 162-164

New South Wales Government, 11 ; $3 \frac{1}{2}$ per cents., 24 ; coal, 61 ; the Soudan War, 378

New Zealand Stock, 28, 61; harbours, 161; flax, 187 ; artillerymen, 193; storm, 213; government, 216; working men, 223-227; shipment of frozen meat, 349

Nicholson, MIr. G., 76

Nimmo, Hon. Mr., 77

Nowlan, MIr, Jobn, 76, 85

$\mathrm{O}$

O’Loughlan, Sir Bryan, 368

Oamaru, 191, 201; harbour, 204207

Orient Line, 4, 297

"Orizaba" s.8., 271, 295-334, 336, 339

Orr, Mr. (manager, Union Bank of Australia), 105

O'Shanassy, Sir John, 75

Otago Harbour, 207, 209, 213

Otaki, 184

Owen, Professor Sir Richard, 74, 400

\section{I'}

Pacific Steam Navigation Co., 297

Paris Nuns, 10

Parkes, Sir H., Preface, iii, x, xxi, 88, 102-106, 127, 161 
Parramatta Tunction, 93; town of, Reid, Mr. Iit. (Pe-ilient ('. of (:), 11, 142

Patterson Inlet, 218

Peel, General, 386

"Penguin" s.s., 157, 305

Peninsular and Oricntal Steam Navigation Co., 3, 4, 301

Perim Island, 321

Perth, Western Australia, 298

Petoné, 176, 179

Picton, 154, 167, 172, 173

Pinschof, Mr., 58

Plimmer, Mr. J., 131, 17t, 181-18t

Plimmerton, 183

Playford, Hon. Mr., 279

Plymouth, 14

Porirua Harbour, 183

Portarlington, 251, 252

Port Chalmers, 210-212

Port Jackson, 99 ; scenery of, 105 ; Heads, 125, 141, 149

Portland Bay, 43, 44, 89

Port Phillip, 37, 43-15, 229, 212 ; military defences, 246-251

Port Said, 323-327

Price, Professor B., 307

Pyramid tiock, 229

\section{Q}

Queenscliff, 243, 246

Queensland $3 \frac{1}{2}$ per cents., 24; stock, 293 ; Premier, 27 ; wool, 60; cats in, 291 ; 362,367

Queensland, 131; National Bank of, Queensland, 132, 137 ; trees in, 133 "Quetta" s.s. at Aden, 319

li

Raleigh, Mrs. Jos., $7 t$

Red Sea, T'ne, 4, 321-3
$5 \pm$; and Mrs., 231

Reid, Mr. J., 201

Renny, Mr. A. K., 71

Revans, Mrr., 222

Richardson, Dr. B. WV., 84

Robertson, Wm. (of Hobart), 20

Riobertson, Mr., 403

Robinson (Sir Wm.), 277, 279

Robson, Mr. Henry, 250

Rockbampton, 139, 403

Rockwell ("Danite"), 10

Rodondo, 229

Rome, 143

Rosebery, Lord, on Australia, 385

lioss, Alfred, and A. G., 39, $7 t$

Ross, Mr. Jolnn, 168-172

Rothschilds, one of the elder, 239

Rounding, Captain, 150

Royal Colonial Institute, Preface, xiii, $352,379,385,388$

Ruapetu Island, 220

Rucker's Hill, 45

Russell, 151

Ryrie, Wm. and Donald, 232

\section{S}

St. Hubert Vineyards, 232

st. Vincent Gulf, 43

Salisbury, Lord, and foreign policy, Preface, xvi

Salt Water River, 240

Samoa and Germany, 354, 355

Sandgate, 136

Sandhurst, 215, 216; gold mines at, 257

Saudridge, 37,80

Sandy Bay, 229

Santa Cruz (capital of 'l'eneriffe), 16

Sargood, Colonel, 53, 56

Schleswig-Holstein, Prince of, 1850, 85 
Scott, Mrs., 252

Scrimgeours, Messrs., 181

Service, Mr. (ex-Premier of Victoria), $11,104,374$

Shadforth, Mr., 58

Sharp, Mr. T., 166

Shaw, Mr., 234-237

Shaw Savill Line, 5

Siddons, Mrs., 333

Smillie Family, 275

Smith, Adam, the Economist, 359

Smith, Mr. Barr, 282

Smith, Joseph (Mormon), called the "Prophet," 7

Smith, Rt. Hon. W. H., on Unity of the Empire, 377, 387

Snowdon, Mr., 346, 348

Society of Arts, 84

Socotra, Island of, 313

Standard Bank of S. Africa, 17

Station Peak of the Anakies, 37

Stawell, Sir Wm., 76, 218

Stewart, Mrs., 331, 332

Stewart's Island, 217, 219

Strachan, Mr. J. F., 245

Stradbroke, 129

Stromboli, Mount, 329

Sturt and Sturt Desert, 343

Suez Canal, 323, 324

Sunbury, 241

Swan River, 42, 301

Sydney, 93; Rōerts' Hotel, 94 ; comparison with Melbourne, 94 to 98; George Street, 95 ; trams in, 96 ; 'own Hall, 97 ; New Hospital, 97 ; commerce, 98 ; population, 98; harbour, 99 ; sewerage, 100 ; (iovermment House, 102; Stock Fixchange, 105 ; 122, 143149

'Sydney Herald,' 25, 51; 'Sydney Evening News,' 51, 53

Syme, Mr. (Melbourne 'Age'), 108
$\mathrm{T}$

Table Mountain, 17

Tamar River, 35, 229

Tambo, 342

Taranaki, 169

Tasman Bay, 164, 165, 306

Tasmania, 18; stock, 28, 30 ; Tasmania Main Line, 32-34

Teneriffe Peak, 16, 262

Tenterfield, 139

The Bluff and Harbour, 213-215; Board, 218

Thomson, Dr., 245

Thorneycrofts and torpedo boats, 340

Timaru, 201; harbour, 203; population, 205

'The 'Times,' 290

Toowoomba, 139

'Tropical colonies, government of, 286-289

Tupper, Sir Charles, and Federation, $372,379,380,388$

'Turnbull, Messrs., 174

$\mathrm{U}$

Union Company S. of N. Zealand, 189

Unity of the Empire (or Federation), 374,377 , 385; Preface, viii, xviii ; Pecrage of the Empire, 393

\section{V}

Verdon, Sir George, 242

Victoria, mineral wealth of, 61,98 ; candle-making, 111

Victorian Gold Commission, 18511855, 179, 255 


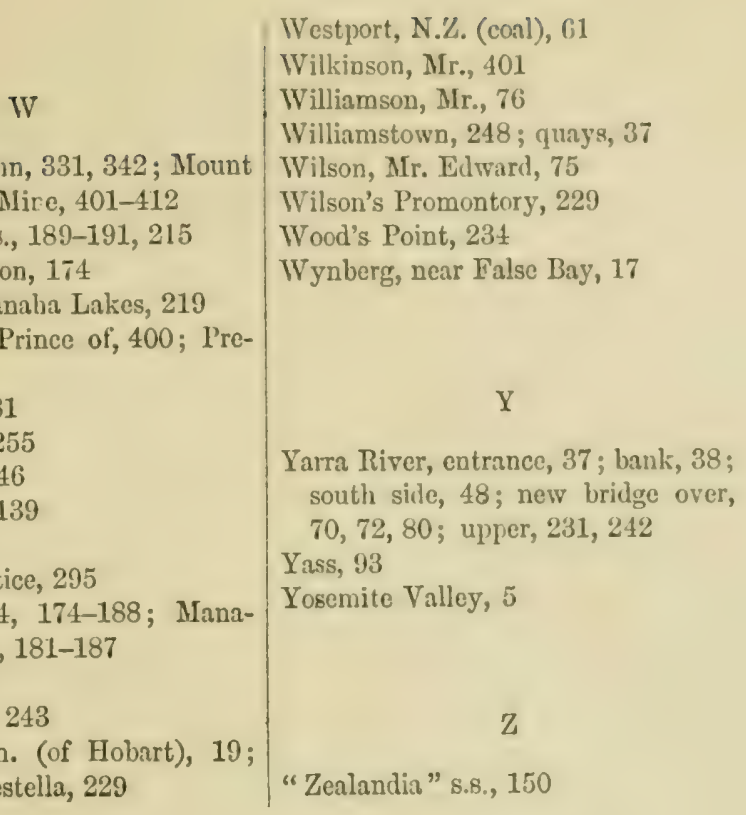





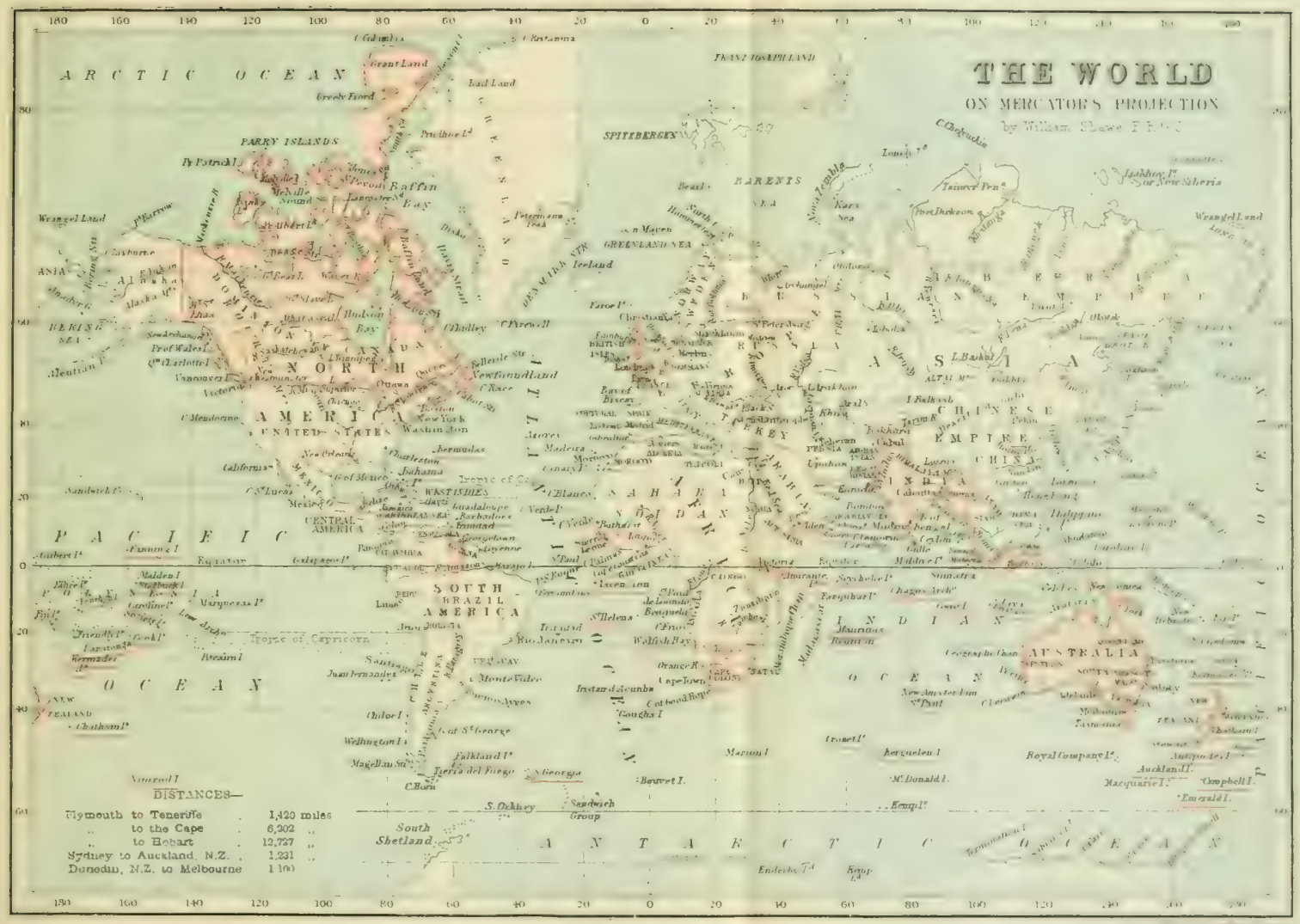





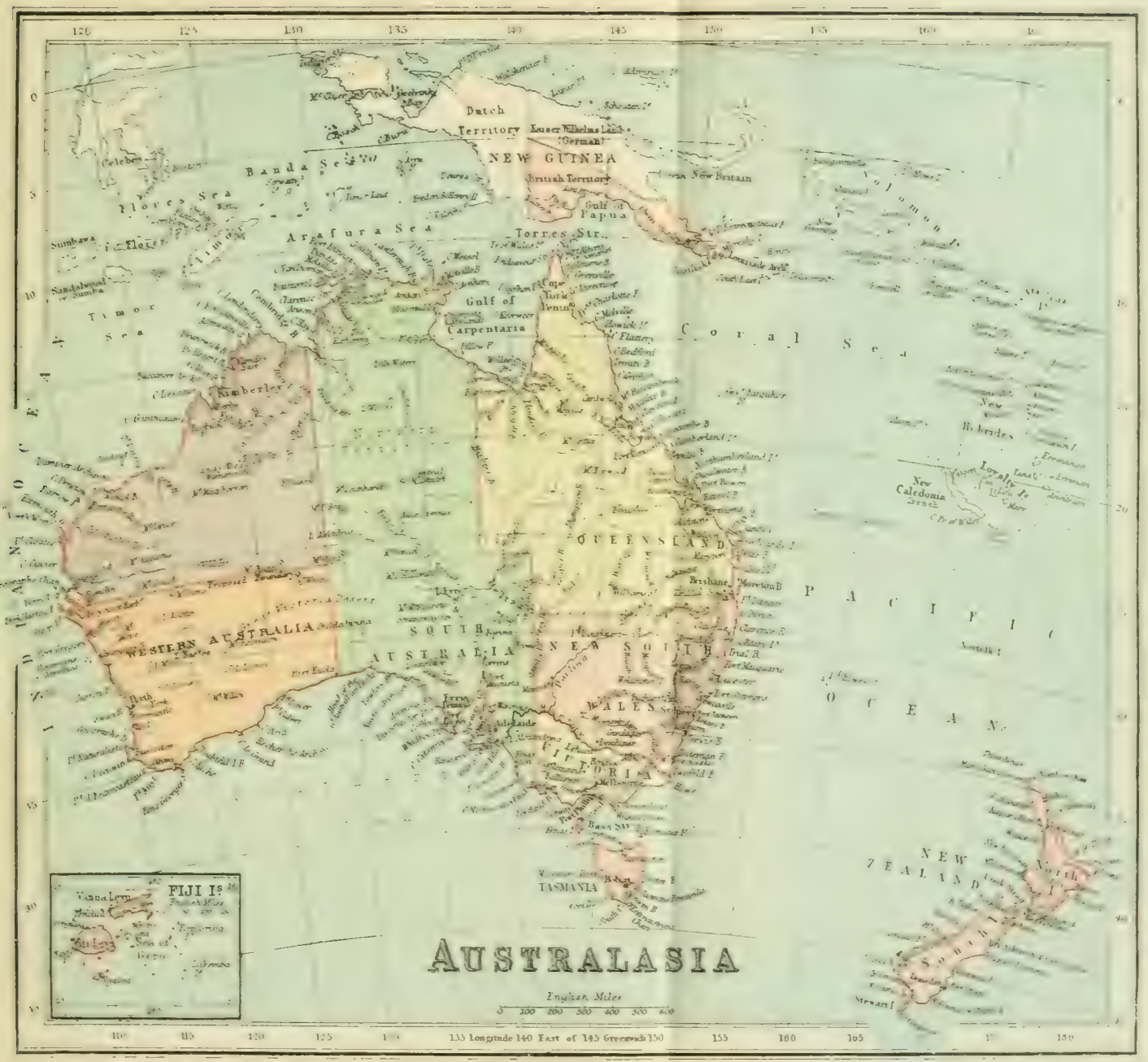





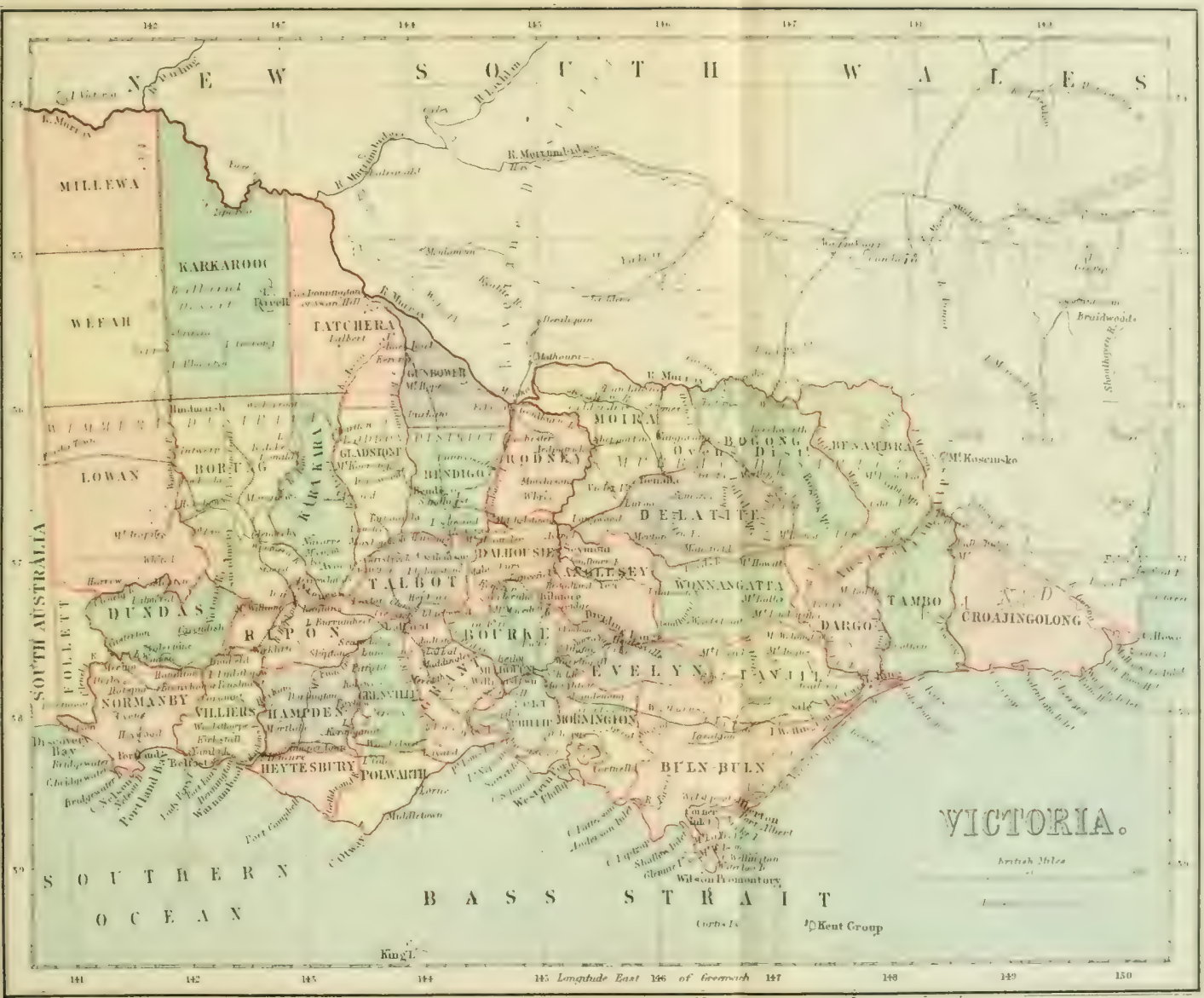

BLMPSON LOW \& $\mathrm{CO}$ 




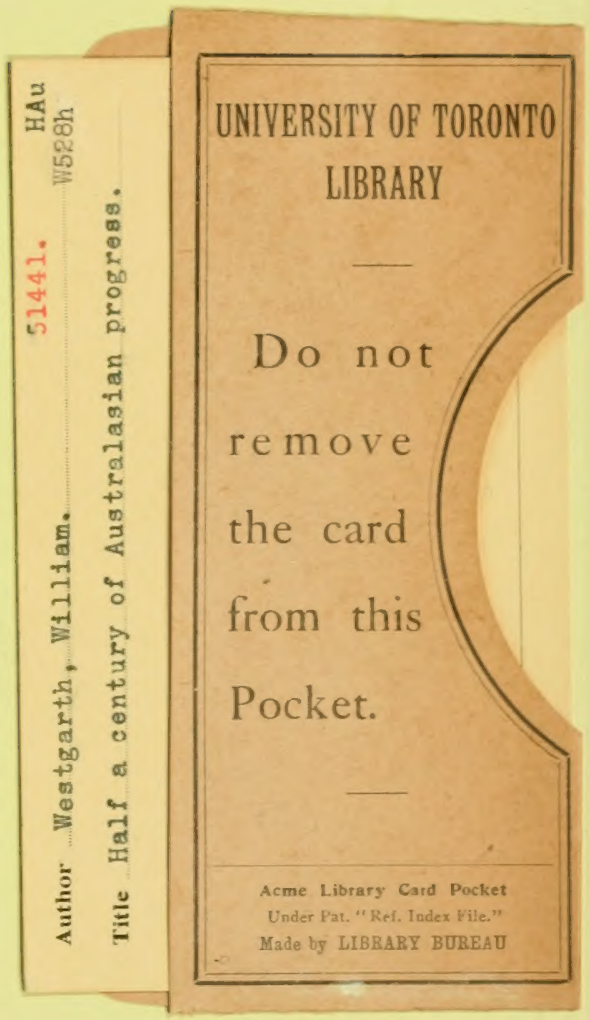




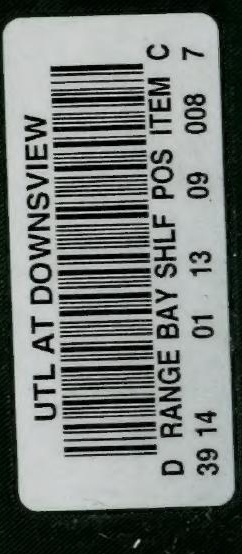

